Portland State University

PDXScholar

\title{
The collapse of the German army in the East in the summer of 1944 (Volume 1)
}

Stephen Ariel Veal

Portland State University

Follow this and additional works at: https://pdxscholar.library.pdx.edu/open_access_etds

Part of the European History Commons, and the Military History Commons Let us know how access to this document benefits you.

\section{Recommended Citation}

Veal, Stephen Ariel, "The collapse of the German army in the East in the summer of 1944 (Volume 1)" (1991). Dissertations and Theses. Paper 4301.

https://doi.org/10.15760/etd.6183

This Thesis is brought to you for free and open access. It has been accepted for inclusion in Dissertations and Theses by an authorized administrator of PDXScholar. Please contact us if we can make this document more accessible: pdxscholar@pdx.edu. 
AN ABSTRACT OF THE THESIS OF Stephen Ariel Veal for the Master of Arts in History presented June 10, 1991.

Title: The Collapse of the German Army in the East in the Summer of 1944 .

APPROVED BY MEMBERS OF THE THESIS COMMITTEE:

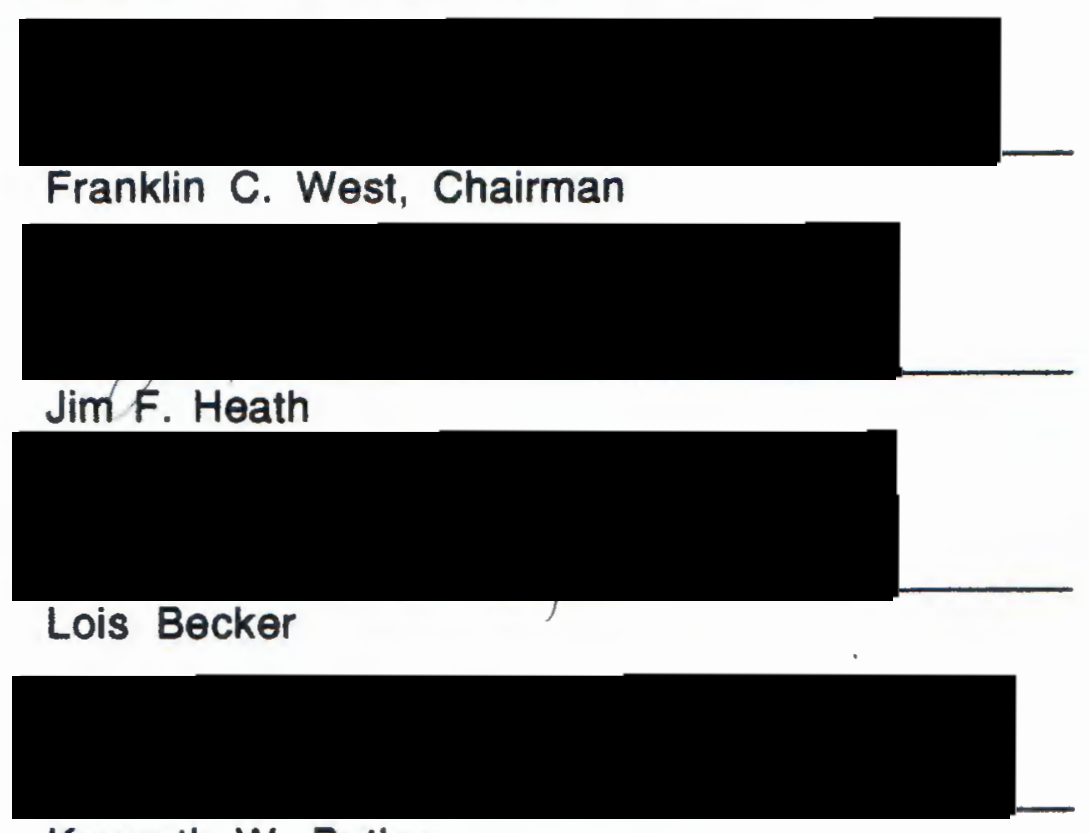

Kenneth W. Butler

The collapse of the German Army in the East in the Summer of 1944 is analzyed and determined to be the result of the following specific factors: German intelligence failures; German defensive doctrine; loss of German air superiority; Lend-Lease aid to the Soviet Union; German mobile reserves committed in the West; Soviet numerical superiority; and Soviet offensive doctrine and 
tactics. The collapse of Army Group Center, the destruction of the XIII Army Corps, and the collapse of Army Group South Ukraine in Rumania during the Summer of 1944 are examined in detail. The significance of the collapse of the German Army in the East is compared to events occuring on the Anglo-American fronts and the German losses on both theaters of military operations are compared. The Soviet contributions to the defeat of the German Army during the Summer of 1944 are examined and the views of Soviet historiography and American historiography compared. 
THE COLLAPSE OF THE GERMAN ARMY

IN THE EAST IN THE SUMMER OF 1944

Volume 1

by

STEPHEN ARIEL VEAL

A thesis submitted in partial fulfillment of the requirements for the degree of

\author{
MASTER OF ARTS \\ in \\ HISTORY
}

Portland State University

1991 
TO THE OFFICE OF GRADUATE STUDIES:

The members of the Committee approve the thesis of Stephen Ariel Veal presented June 10, 1991.

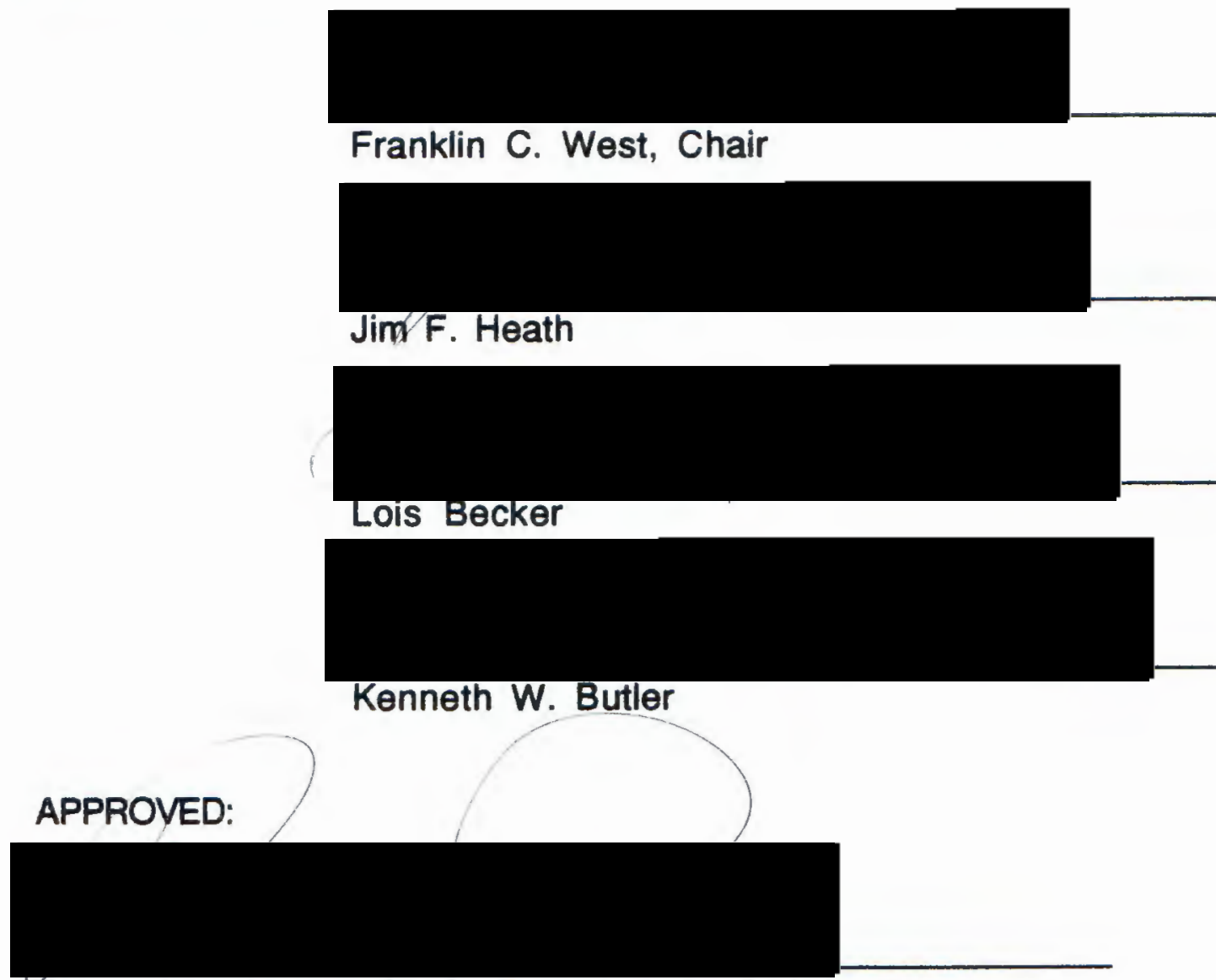

Bernard V. Burke, Chair, Department of History

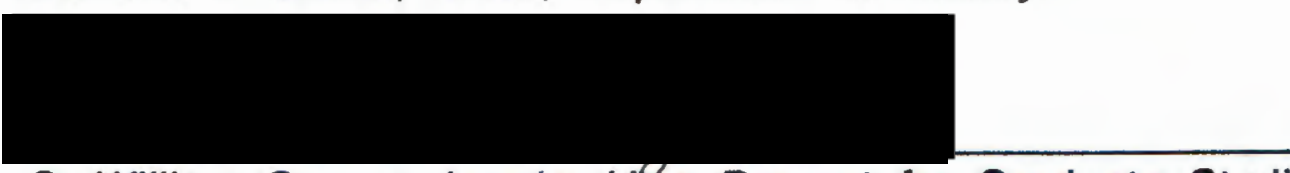

C. William Savery, Interim Vice Provost for Graduate Studies and Research 


\section{TABLE OF CONTENTS}

\section{PAGE}

LIST OF TABLES

$\mathbf{x i}$

LIST OF FIGURES

xviii

CHAPTER

I INTRODUCTION

1

Notes To Chapter I

II THE FAILURE OF GERMAN MILITARY

INTELLIGENCE TO PREDICT THE

SCHWERPUNKT OF THE SOVIET SUMMER

OFFENSIVE IN 1944

18

Foreign Armies East And Oberkommando Des Heeres

Army Group Center's Projection Of The Soviet Summer Offensive

Soviet Secrecy And Allied

Deceptions In The Summer Of $1944 \quad 42$

Soviet Military Deceptions 
III GERMAN DEFENSIVE DOCTRINE IN 1944:

STANDING FAST VERSES ELASTIC DEFENSE $\quad 69$

Hitler's Doctrine Of Standing Fast 69

Hitler's Wavebreak Doctrine

Elastic Defense And Strategic

Withdrawal: The Last Hope Of Army Group Center

The Lost Potential Of Elastic Defense

Notes To Chapter III

IV AIRPOWER: THE LUFTWAFFE LOSS OF SUPERIORITY

Luftwaffe: Strategic Air Warfare In The East

Luftwaffe And Soviet Command And Control

Numerical Comparison Of The

Luftwaffe And The Soviet Air Force 94

The Luftwaffe Anti-Tank Support 99

Soviet Air Force Objectives In The

Belorussian Campaign And

Comparison Of German And Soviet

Sortie Rates

Comparison Of Eastern And

Western Fronts 
$\checkmark$ LEND-LEASE AND ITS IMPACT ON THE COLLAPSE OF THE WEHRMACHT IN THE EAST IN THE SUMMER OF 1944

Lend-Lease Aircraft In The Soviet Union

The Impact Of Lend-Lease Motor Vehicles In The Soviet Union

Soviet And German Motor Vehicle Production

Soviet And German Tank Production

Notes To Chapter V

VI THE SECOND FRONT: THE IMPACT ON GERMAN MOBILE RESERVES

German Order Of Battle In The West And The East In The Summer Of $1944 \quad 162$

VII PRELUDE TO THE BELORUSSIAN SUMMER OFFENSIVE: THE WINTER BATTLES OF THE FOURTH ARMY AND THE THIRD PANZER

ARMY IN THE WINTER OF 19431944

Fourth Army

Third Panzer Army

Soviet Resources And Strategy In

The Winter Battles of 1943-1944 
Soviet Tactical Failures

204

Notes To Chapter VII

229

VIII SOVIET OPERATIONAL PLANNING, NUMERICAL SUPERIORITY AND THE USE OF MASS IN THE BELORUSSIAN SUMMER OFFENSIVE

Soviet Operational Planning

Final Stavka Plan

240

Numerical Superiority

Concentration And Mass In The Soviet Offensive In Belorussia

Notes To Chapter VIII

276

IX THE COLLAPSE OF ARMY GROUP CENTER

IN THE SUMMER OF 1944

282

June 22, 1944

285

June 23, 1944

288

June 24, 1944

295

June 25, 1944

305

June 26, 1944

316

June 27, 1944

329

June 28, 1944

June 29, 1944 


\begin{tabular}{|c|c|}
\hline July 1,1944 & 371 \\
\hline July 2, 1944 & 383 \\
\hline July 3, 1944 & 393 \\
\hline July 4, 1944 & 405 \\
\hline July 5, 1944 & 411 \\
\hline July 6, 1944 & 419 \\
\hline July 7,1944 & 426 \\
\hline July 8, 1944 & 433 \\
\hline July 9, 1944 & 438 \\
\hline July 10,1944 & 445 \\
\hline July 11,1944 & 449 \\
\hline July 12, 1944 & 453 \\
\hline July 13, 1944 & 456 \\
\hline July 14-31, 1944 & 458 \\
\hline Fortress Brest-Litovsk & 459 \\
\hline July 25, 1944 & 460 \\
\hline July 26, 1944 & 461 \\
\hline July 27, 1944 & 465 \\
\hline July 28, 1944 & \\
\hline
\end{tabular}


July 29, 1944

467

The Causes Of The Collapse Of Army Group Center And The Significance Of The German Losses To The Eastern Front 468

Notes To Chapter IX 602

$X \quad$ ARMY GROUP NORTH UKRAINE AND THE DESTRUCTION OF THE XIII ARMY CORPS, JULY 13-23, 1944

July 13, 1944

639

July 14, 1944

640

July 15, 1944

642

July 16,1944

643

July 17,1944

646

July 18, 1944

649

July 19, 1944

653

July 20, 1944

658

July 21, 1944

663

July 22, 1944

673

July 23, 1944

German Losses In The Battle Of Brody, July 13-23, 1944 
XI ARMY GROUP SOUTH UKRAINE AND THE

German Intelligence Failure in

Rumania

Rumanian Reliability

720

The Status Of German And Rumanian

Forces Prior To The Soviet Offensive On August 20, 1944

August 20, 1944

August 21. 1944

August 22, 1944

August 23, 1944

August 24, 1944

August 25, 1944

753

August 26, 1944

755

August 27, 1944

758

August 28, 1944

761

August 29, 1944

763

August 30,1944

766

August 31,1944

768

September 1, 1944

770

September 2, 1944 
September 3, 1944

September 4, 1944

September 5, 1944

777

Conclusion

780

Notes To Chapter XI

830

XII THE RUSSIAN FRONT IN PERSPECTIVE:

COMPARISON OF LOSSES BETWEEN

EASTERN AND WESTERN FRONTS

Notes To Chapter XII

891

XIII CONCLUSION

892

REFERENCES

905

APPENDICES

$\begin{array}{lll}\text { A } & \text { GERMAN MILITARY FORMATIONS } & 924 \\ \text { B } & \text { SOVIET MILITARY FORMATIONS } & 936 \\ \text { C } & \text { DOCUMENTS } & 947\end{array}$ 


\section{LIST OF TABLES}

TABLE

PAGE

I Deployment of Soviet Armies on Two

Fronts, 22 June 1944

II Luftwaffe Aircraft Distribution by

Front, August 1943

104

111 Luftwaffe Aircraft Distribution by

Front, June 1944

104

IV Distribution of Air Forces in the Individual Luftflotten, June 1944

V Distribution of Air Forces in the Different Luftflotten, August 1944

VI Distribution of Luftwaffe Frontal Aircraft Losses (Total Losses and Disabled Aircraft), June to October 1944

VII Annual Lend-Lease Shipments to the Soviet Union (Thousands of Tons and Percentage of Soviet Total)

VIII Lend-Lease Shipments to the USSR, July 1942 - June 1943

IX Lend-Lease Shipments to the USSR, July 1943 - June 1944

$X \quad$ Aircraft Deliveries to the Soviet Union, 1 October 1941 - 31 July 1943 
XI Vehicles Delivered to the Soviet Union Under the Lend-Lease Program

XII Motor Vehicles and Railroad

Transportation Equipment, June 22, 1941 - September 2, 1945

XIII German Production of Motor Vehicles 1944

XIV Motor Vehicle Production in Occupied Countries

XV Soviet Armored Vehicle Production in the Second World War

XVI German Panzer Production: Tanks, Assault Guns and Self-Propelled Guns

XVII Comparison of Soviet and German Armored Vehicle Production 1940-1945

XVIII German Mobile Divisions, Order of Battle in the West, June 1944

XIX German Order of Battle in the West for Infantry, Parachute, Air Landing, Jaeger, Mountain, Cavalry, and Luftwaffe Field Divisions in June 1944

XX German Mobile Divisions, Order of Battle in the East, June 1944

XXI German and Axis Order of Battle in the East for Infantry, Jaeger, Mountain, and Luftwaffe Field Divisions in June 1944

XXII German 4th Army Order of Battle, October 26, 1943 
TABLE

PAGE

XXIII German 4th Army Order of Battle, November 8, 1943

XXIV German 4th Army Order of Battle, December 3, 1943

XXV German 4th Army Order of Battle, December 14, 1943

XXVI German 3rd Panzer Army Order of Battle, December 14, 1943

XXVII German 3rd Panzer Army Order of Battle, December 26, 1943

XXVIII Soviet Order of Battle, June 1944

XXIX Men and Equipment of Soviet Fronts, June 20, 1944

$X X X \quad$ Soviet Effective Aircraft Strength in the Soviet Air Armies Prior to the Opening of the Belorussian Offensive

XXXI Operational Density of Soviet Troops on the Belorussian Front

XXXII Soviet Attacking Echelons Against Army Group Center

XXXIII Soviet Armored Density Opposite Army Group Center, June 20, 1944

XXXIV Soviet Artillery Density and Frontages

Opposite Army Group Center, June 20, 1944

XXXV Army Group Center Order of Battle June 22, 1944 
TABLE

PAGE

XXXVI Overview of the Combat Readiness,

Strength and Reserves of the 4th Army

on June 20, 1944

481

XXXVII Battle Strength of Corps Detachment E on July 25, 1944

XXXVIII Combat Report of the 1st Flieger Division for July 26, 1944

$X X X \mid X \quad$ Operational Order of Battle of the Flying Formations of Luftflottenkommando 6, June 28, 1944

$\$ 00 \times$ Reinforcements for Army Group Center June-August 1944

$X X X X \mid$ The Destruction of Army Group Center

XXXXII Soviet Order Of Battle, July 13, 1944

681

XXXXIII Soviet Numerical Superiority

682

XXXXIV Army Group North Ukraine Order of Battle, July 15, 1944

XXXV Army Group North Ukraine Losses At

The Battle Of Brody

$X X X X V I \quad$ Army Group North Ukraine

Reinforcements From August 1-31, $1944 \quad 688$

XXXXVII Operational Density of Soviet Forces,

August 20, 1944

XXXXVIII Soviet Order of Battle Opposite Army Group South Ukraine 
XXOXIX Army Group South Ukraine Order of

Battle, August 15, 1944

786

L Soviet and German Comparison

of Forces

LI Army Group South Ukraine Divisional

Frontage, July 23, 1944

LII Rumanian Division Frontage in Army Group Dumitrescu and Army Group

Woehler on July 23, 1944

LIII The Destruction of Army Group

South Ukraine

LIV Comparison of Troop Losses Between the Eastern and Western Fronts from June-August 1944

LV German Losses by Front from June-November 1944

LVI Comparison of Armored Vehicle Losses between the Eastern Front and the Anglo-American Fronts, June 1944

LVII Comparison of Armored Vehicle Losses between the Eastern Front and the Anglo-American Fronts, July 1944

LVIII Comparison of Armored Vehicle Losses between the Eastern Front and the Anglo-American Fronts, August 1944

LIX Comparison of Armored Vehicle Losses between the Eastern Front and the Anglo-American Fronts, June-August 1944 
$L X$

Comparison of Armored Vehicle Shipments between the Eastern Front and the Anglo-American Fronts, June-August 1944

LXI Comparison of Non-Armored Vehicle Losses between the Eastern Front and the Anglo-American Fronts, June 1944

LXII Comparison of Non-Armored Vehicle Losses between the Eastern Front and the Anglo-American Fronts, July 1944

LXIII Comparison of Non-Armored Vehicle Losses between the Eastern Front and the Anglo-American Fronts, August 1944

LXIV Comparison of Non-Armored Vehicle Losses between the Eastern Front and the Anglo-American Fronts, June-August 1944

LXV Non-Armored Vehicle Shipments

To the Eastern Front and the

Anglo-American Fronts, June-August 1944

LXVI Luftwaffe Frontal Aircraft Losses (Total Losses and Disabled Aircraft) on the Eastern Front and the AngloAmerican Fronts, June-October 1944

LXVII German Generals Killed, Missing or Taken Prisoner on the Anglo-American Fronts during the Summer of 1944 
LXVIII German Generals Killed, missing or Taken

Prisoner on the Eastern Front during the

Summer of 1944

LXIX German Divisions destroyed on the Anglo-American Fronts during the Summer of 1944

886

LXX German Divisions destroyed on the Eastern Front during the Summer of $1944 \quad 888$ 


\section{LIST OF FIGURES}

FIGURE

PAGE

1 German Intelligence Channels

2 Probable Disposition and Direction of the Present and Remaining Anticipated Soviet Offensive Operations, March 29, 1944

3 Probable Soviet Operational Directions and Current Enemy Force Deployment, May 3, 1944

4 Probable Soviet Operational Directions and Current Enemy Force Deployment, May 3, 1944

5 Probable Soviet Operational Intentions and Current Enemy Force Deployment, June 13, $1944 \quad 56$

6 Probable Soviet Operational Intentions and Current Enemy Force Deployment, June 13, $1944 \quad 57$

7 Belorussian Partisan Rail Attacks, June 19-20, 1944

8 Employment of Soviet Tank Formations Opposite the German Eastern Front, May 3, 1944

9 The Six Tank Armies of the Red Army, Order of Battle on June 17, 1944 as Noted by Fremde Heer Ost

10 Deployment of Soviet Forces by the Start of the Belorussian Operation 
11 German Elastic Defense, 1933

12 Western Russia

15 Stellungsbaukarte, June $1944 \quad 84$

16 Soviet Production Centers

17 The Luftwaffe's Last Strategic Victory in the East

18 Luftflotten Boundaries

19 Tactical Subordinate Relationships in the German Air Force

20 Command Organization and Chain of Command for Operations of Flying Units in Support of the Army by Interdiction of the Battlefield

21 Command Relationships Between Luftwaffe And Army On The Eastern Front, 25 December 1943

22 Luftflotten Eastern Front, June 1944

23 German Airplane Production By Type And By Year, 1933-1944

24 Number of German Aircraft Produced by Types, 1939-44

25 Aviation Gasoline Production, Consumption and Stocks, January 1940-April 1945 
FIGURE

PAGE

26 Operation of IV Panzer and 9th Ground Attack Wing on July 8, 1943 at Bjelgorod

27 Luftwaffe Prevents The Union Of Two Armies During The Battle Of Orel Bend

28 Schematic Presentation Of Control of An Armored Breakthrough On The Eastern Front, South, 1944

29 Routes To Russia

30 Convoy Routes To North Russia

31 Middle East Supply Routes

32 German Truck Production

33 Soviet Tank Strength 1941-1945

34 German Defense In Place With Mobile Reserves: Winter 1943-1944

35 Probable Russian Operational Objectives in the First Battle of Vitebsk

36 Probable Russian Operational Objectives in the Second Battle of Vitebsk

37 Breakthrough At Nevel

38 Battle of Vitebsk, December 13, $1943 \quad 216$

39 Battle of Vitebsk, December 15, 1943

40 Battle of Vitebsk, December 18, 1943

218

41 Battle of Vitebsk, December 19-22, 1943 
42 Battle of Vitebsk, December 23-24, $1943 \quad 220$

43 Battle of Vitebsk, December 28, 1943

44 Battle of Vitebsk, December 31, $1943 \quad 222$

45 Battle of Vitebsk, January 6, 1944

46 Battle of Vitebsk, January 11, 1944

47 Battle of Vitebsk, January 17, 1944

48 Battle of Vitebsk, February 3, 1944

49 Battle of Vitebsk, February 16, 1944

50 Soviet Winter Penetrations Around Vitebsk, 1943-1944

51 Basic Concepts And Phases, Planning Memorandum, 20 May $1944 \quad 264$

52 Final Stavka Concept Of Operation 265

53 Major Elements Of Front Plans 266

54 Time Table: Operation Bagration 267

55 3rd Belorussian Front Shock Groups 268

56 Principal Rail Lines in European Russia 1941-1944

57 Partisan Situation June $1944 \quad 270$

58 Partisans in the Army Group Center Rear Area, November 1943-March 1944 
FIGURE

PAGE

59 Operations Regenschauer, Fruehlingsfest, and Kormoron, April-June 1944

60 Rail Lines Behind Army Group Center

61 Soviet-German Force Relationships And Soviet Front Superiority

62 German River Defensive Position on the Eastern Front

63 The Six Staggered Offensives Of The Red Army During "Operation Bagration."

64 Army Group Center Under Attack, June 22, 1944

65 3rd Panzer Army Order Of Battle, June 1944

66 3rd Panzer Army - Situation On June 22, 1944

499

67 The Situation Of The 3rd Panzer Army On June 22, 1944

68 4th Army Order Of Battle, June 1944

501

69 9th Army Order Of Battle, June 1944

502

70 2nd Army Order Of Battle, June 1944

503

71 Army Group Center, June 23, 1944

504

72 The Situation Of The 3rd Panzer Army On June 23, 1944 At 1000 hrs

73 Vitebsk, June 23, 1944 506

74 3rd Panzer Army - Situation On June 23, 1944 
FIGURE

PAGE

75 Army Group Center, June 24, $1944 \quad 508$

76 The Situation Of The 3rd Panzer Army On June 24, 1944 At 1000 hrs

77 The Hole Between LIII And VI Army Corps, June 24, 1944

78 The Soviet Breakthroughs On The 9th Army Front, June 24, 1944

79 The Soviet Breakthrough On The Left Flank Of

The 4th Army, June 24, 1944

80 The Hole Between The 337th And 12th Infantry

Divisions, June 24, 1944

81 The Soviet Breakthroughs On The 9th Army Front, June 24, 1944

82 The Situation Of The 3rd Panzer Army On June 22, 1944

83 The Encirclement Of The LIII Army Corps, June 25, 1944

84 The Hessen and Bear Defensive Lines

85 Army Group Center, June 25, 1944

86 Bridgehead Orsha, Dnieper Covering Position, Hessen and Bear Lines

87 Soviet Advance On Bobruisk, June 24-25, $1944 \quad 520$

88 The 9th Army Situation On June 25, 1944

89 Bobruisk Bridgehead And 9th Army

Defensive Lines 
FIGURE

PAGE

90 The Situation Of The 3rd Panzer Army On June 26, 1944

91 Breakout From Vitebsk

524

92 Soviet Encirclement Of Vitebsk

525

93 LIII Army Corps And 206th Infantry Division On June 26, 1944

94 Army Group Center, June 26, 1944

527

95 The 25th Panzer Grenadier Division's Sector On June 22, 1944

96 The Bear Line

529

97 Soviet Control Of Titowka Road Junction

530

98 Soviet Operations Against The 9th Army, June 24-27, 1944

99 JS-122 Joseph Stalin

100 Army Group Center, June 27, 1944

101 The Situation Of The 3rd Panzer Army On June 27, 1944

102 Soviet Breakthrough Into Rear Of 4th Army, June 27, 1944

103 Fortress Orsha

105 The Impending Encirclement Of The 4th Army, June 27, 1944 
106 The Soviet Encirclement Of Bobruisk, June 27, 1944

107 The 9th Army Situation On June 27, 1944

108 The Eastern Acess Into Bobruisk: The Road And Railway Bridges Across The Berezina River 541

109 The Situation Of The 3rd Panzer Army On June 28, 1944

110 Army Group Center, June 28, 1944

111 The Principal Roads Used In The Retreat Of Army Group Center

112 The Situation Of The 3rd Panzer Army On June 29, 1944

113 Army Group Center, June 29, 1944

114 The Breakout From Bobruisk

115 Army Group Center, June 30, 1944

116 Fortress Borisov

117 Fortress Ssluzk

118 Fortress Minsk

119 9th Army Order Of Battle, June 30, 1944

121 The Situation Of The 3rd Panzer Army On July 1, 1944 
123 Soviet Eastern Advance Toward Minsk On July 1, 1944

124 Army Group Center, July 2, 1944

125 The Situation Of The 3rd Panzer Army On July 2-4, 1944

126 The Position Of Army Group Center On July 2, 1944 At $1200 \mathrm{Hrs}$

127 The Situation Of The 3rd Panzer Army On July 5, 1944

128 Army Group Center, July 3, 1944

129 The Retreat Of The 4th Army And 9th Army Towards Minsk

130 Army Group Center, July 5, 1944

131 Fortress Baranowicze

132 The Situation Of The 3rd Panzer Army On July 5, 1944 In The Evening

133 The 4th Panzer Division, 12th Panzer Division And The 28th Jaeger Division On July 5, 1944

134 The Red Army's Offensive Thrusts, June 22 - July 5, 1944

135 The Situation Of The 3rd Panzer Army On July 6, 1944 In The Evening

136 Army Group Center, July 6, 1944 
FIGURE

PAGE

138 3rd Panzer Army's IX Army Corps On July 7, 1944 In The Evening

139 Fortress Wilna, July 7, 1944 In The Evening

140 Soviet Encirclement Of Wilna, July 8, 1944

141 IX Army Corps, July 8, 1944

142 Army Group Center, July 8, 1944

575

143 Fortress Wilna, Kampfgruppe Tolsdorf

And Panzer Grenadier Brigade von Werthern, July 9, 1944

144 Army Group Center, July 9-10, 1944

145 Fortress Wilna And Kampfgruppe Tolsdorf, July 10, 1944

146 IX Army Corps, July 10, 1944

579

147 Gruppe von Vormann, Order Of Battle, July 10, 1944

148 SS Parachute Battalion 500 And Panther Battalion Of The Panzer Division "GrossDeutschland."

149 IX Army Corps, July 11, 1944

150 4th Army, July 11, 1944

152 Panzer Grenadier Brigade von Werthern's Attack On Griedraiciai And The Soviet Advance To Olita, July 12, 1944 
FIGURE

PAGE

153 Army Group Center, July 12, 1944

586

154 Kampfgruppe Tolsdorf, July 13, 1944

587

155 The Breakout Of The Garrison Of Fortress Wilna, July 13, 1944

588

156 Army Group Center, July 13, 1944

589

157 Fortress Brest-Litovsk

590

158 The Garrison Of Fortress Brest-Litovsk

591

159 Soviet Attacks Southwest And Northwest Of Fortress Brest-Litovsk, July 25, 1944

160 Soviet Attacks Southwest, Northwest

And East Of Fortress Brest-Litovsk, July 26, 1944

161 The Situation Of Fortress Brest-Litovsk On The Morning Of July 26, 1944

162 The Encirclement Of Fortress Brest-Litovsk On July 27, 1944

163 The Breakout Of The Garrison Of Fortress

Brest-Litovsk On July 28, 1944

596

164 The Relief And Arrival Of Kampfgruppe Felzmann At The German Western Defense Line, July 28, 1944

165 The 2nd Army, July 29-30, 1944

598

166 Soviet Tank Corps

599

167 Soviet Mechanized Corps

600 
170 Army Group North Ukraine Under Attack On The Flanks Of The XIII Army Corps, July 15, 1944

171 Army Group North Ukraine, July 15, 1944

172 Soviet Attacks On The Flanks Of The XIII Army Corps, July 16, 1944

174 Soviet Attacks On The Flanks Of The XIII Army Corps, July 17, 1944

175 Army Group North Ukraine, July 17, 1944 695

176 The Encirclement Of The XIII Army Corps On July 18, 1944

177 The 4th And 1st Panzer Armies, July 19, 1944

178 The Encircled XIII Army Corps, July 19, 1944

179 The 4th And 1st Panzer Armies, July 20, 1944 699

180 The Breakout Of The XIII Army Corps, July 20, 1944

181 The 4th And 1st Panzer Armies, July 21, 1944

182 Army Group North Ukraine, July 22, 1944

183 The XIII Army Corps, July 22, 1944 
185 The Soviet And Axis Deployment In Rumania From June 15th To August 20, 1944

186 Possible Soviet Operational Objectives On August 15, 1944

187 Army Group South Ukraine Order Of Battle, August 1, 1944

188 The Soviet Offensive Against Army Group South Ukraine On August 20, 1944

189 The German Defensive Lines In Rumania, August 10, 1944

190 Army Group South Ukraine, August 21, 1944 804

191 Army Group South Ukraine, August 22, $1944 \quad 805$

192 Army Group South Ukraine, August 23-25, $1944 \quad 806$

193 Army Group South Ukraine, August 26, $1944 \quad 807$

194 The Surrounded 6th Army, August 26, $1944 \quad 808$

195 The Soviet Advance South Of Focsani And The Rumanian Armored Attack On Ploesti, August 26, 1944

196 The Soviet Advance On The Ojtoz Pass And Toward The Carpathians, August 26, 1944

197 The Encircled Elements Of The German 6th Army, August 27, 1944

198 The Soviet Capture Of Focsani And The Drive South, August 27, 1944 
FIGURE

PAGE

199 Soviet Attacks Against The German 8th Army, August 27, 1944

200 Rumanian Armored Reinforcements, August 27, 1944

201 The Encircled Elements Of The

German 6th Army, August 28, 1944

202 Soviet Attacks Against The German 8th Army, August 28, 1944

203 The Encircled Elements of

The German 6th Army, August 29, 1944

204 Army Group South Ukraine, August 29, 1944

205 The 5th Flak Division And Kampfgruppe Stahel In The Area Of Ploesti, August 30, 1944

206 Army Group South Ukraine, August 30, 1944

207 Army Group South Ukraine, August 31, 1944

208 Kampfgruppe Stahel And The 5th Flak Division, August 31, 1944

209 Gruppe Mieth, August 31, 1944

210 Army Group South Ukraine, September 1, $1944 \quad 824$

211 Army Group South Ukraine, September 2, 1944

212 Soviet Attacks Against The German 8th Army, September 2, 1944 
214 The Counterattack Of The 2nd Hungarian Army, September 5, 1944

215 Army Group South Ukraine, September 5, $1944 \quad 829$ 


\section{CHAPTER I}

\section{INTRODUCTION}

The summer of 1944 marked a significant turning point in the war against Nazi Germany. It was pushed back closer to its borders on the Eastern and Western Fronts. The Anglo-American forces had landed in France and the Soviets had entered Poland. The Red Army had overrun Rumania causing it to switch sides against Nazi Germany by the end of August and Finland was seeking an armistice with the Soviet Union. These dramatic events of the summer of 1944 were significant to the defeat of Nazi Germany.

Anglo-American and Soviet operations during the summer of 1944 can be compared to examine the significance of contributions on the Eastern and Western Fronts to the defeat of Nazi Germany in a period of time when both allies were conducting extensive operations. A careful analysis of the contributions made by both the Soviet and Anglo-American allies during the summer of 1944 produces a more balanced view of this period. The Anglo-American allies played the dominant role in the air war against Germany while the Soviet Union was dominant in the ground war. Neither side can claim with any veracity to have been able to defeat Nazi Germany alone. The massive defeats suffered on the Eastern and 
Western Fronts by the German Army in 1944 were based upon the joint contributions made by the Soviet Union and the AngloAmerican allies combined with the mistakes made by Hitler and the German High Command. The factors analyzed in this study will hopefully provide sufficient basis to assess the relative contributions to the defeat of Nazi Germany by the Soviet Union and Western allies.

This study will use quantitative data to determine the significance of each factor in the collapse of the the German Army in the East. Actual military events will be analyzed day by day summarizing the significant events on each army front using the same techniques employed by U.S. military Sigint traffic analysis. The operational and tactical level of military operations will be presented to delineate how the German Army was defeated in the field. The purpose of this study is to present each significant factor as a case study in the analysis of the collapse of the German Army in the East in the summer of 1944. The day by day analysis of operational and tactical military actions will delineate the combination of decisions and actions which lead to military disasters which could have possibly been avoided. This study will prove useful as a case study of a numerically inferior army on the defense against the Red Army which would have been similiar to the conditions which existed between NATO and the Warsaw Pact armies prior to German unification.

This work is directed toward professionals familiar with detailed military analysis such as military historians, military 
professionals, military analysts and intelligence analysts. This work is not intended for the general reader because of the extensive in depth detail employed to analyze the factors behind the collapse of the German Army in the East during the summer of 1944. The actual day by day summaries of operations on the Eastern Front are highly detailed and directed toward professionals accustomed to the use of extensive in depth military detail.

German writers have presented narrative accounts of the German defeats in the East during the summer of 1944.1 However, this study is unique from other studies done in German with the detailed major differences being the examination of the following factors: military intelligence, defensive doctrine, air superiority, Lend-lease, mobile reserves and the impact of Soviet strategy and tactics. Furthermore, this study is unique by examining the day by day details of the three major events on the Eastern front during the summer of 1944: (1) the collapse of Army Group Center; (2) the destruction of the XIII Army Corps in Army Group North Ukraine; and (3) the collapse of Army Group South Ukraine.

The failure of German military intelligence to determine the main direction of the Soviet offensive during the summer of 1944 had disastrous results. The Germans had limited mobile and infantry reserves to meet the Soviet summer offensive. It was, therefore, imperative for the Germans to deploy their reserves in the area where they would be available to meet the main Soviet offensive thrust. The placement of the scarce Panzer divisions to act as mobile reserves to prevent encirclement of German infantry was crucial to the survival of the Wehrmacht in the East. 
The following German Panzer and Panzer Grenadier Divisions were available on the Eastern Front to act as mobile reserves on June 15, 1944: 1st Panzer Division, 3rd Panzer Division, 3rd SS Panzer Division "Totenkopf," 4th Panzer Division, 5th Panzer Division 7th Panzer Division, 8th Panzer Division, 10th Panzer Grenadier Division, 12th Panzer Division, 13th Panzer Division, 14th Panzer Division, 16th Panzer Division, 17th Panzer Division, 18th Panzer Grenadier Division, 20th Panzer Division, 20th Panzer Grenadier Division, 23rd Panzer Division, 24th Panzer Division, 25th Panzer Grenadier Division, 60th Panzer Grenadier Division "Feldherrnhalle," 11th SS Panzer Grenadier Division "Nordland" and Panzer Division "Grossdeutschland."

If the Germans could have deployed these reserves correctly then they could have prevented the destruction of Army Group Center which would have then prevented the draining of reserves from Army Groups North, North Ukraine and South Ukraine which then weakened their defensive capabilities against subsequent Soviet offensives launched against them. Army Group Center constituted a dike against the onrushing torrent of the Red Army and once it was breached the entire Eastern Front gave way and the front was only stabilized once the Red Army entered Eastern Europe.

Foreign Armies East made inaccurate predictions about the main thrust of Soviet offensive operations for the summer of 1944. Foreign Armies East continued to predict that the Soviet main effort would be against Army Group North Ukraine. Foreign Armies 
East continued to hold this position despite increasing evidence that offensive operations were imminent against Army Group Center. German intelligence failed to identify the movement of Soviet tank armies opposite Army Group Center. Soviet radio silence and deception measures contributed to German confusion which prevented accurate intelligence assessments. Soviet air superiority also prevented adequate German aerial reconnaissance which deprived the Germans of a significant source of information. Therefore, the failure of intelligence was to play a central role in the collapse of the German Army in the East during the summer of 1944 .

Hitler's defensive doctrine of "standing fast" completely handicapped the German Army on the defense. Hitler forbid the German Army from using a flexible defense which would have permitted the use of gradual withdrawal and counterattack to absorb Soviet attacks. Hitler instead insisted that each German defensive line be held to the very end before permitting any withdrawals. This resulted in Soviet breakthroughs and penetration of German flanks and subsequent Soviet encirclements of German units. Entire German Armies and Corps would then be forced to fight for their survival in breaking out to the rear and in the process loosing the bulk of their heavy weapons. The German Army as a result often was forced to destroy their own equipment during breakouts from encirclements to prevent it from being captured by the Red Army. 
Hitler's Wavebreak Doctrine dictated that the army must make an "inflexible stand" and defensive lines in depth in the rear were not to be employed since Hitler believed that soldiers would not "standfast" if they could retreat to prepared defensive positions in the rear. Hitler established by decree numerous fortresses on the Eastern Front which were to be defended like medieval fortresses in earlier centuries. However, this notion was clearly anachronistic given the mobility and firepower of the Red Army. The tying down of German forces defending fortresses merely deprived local commanders of flexibility in deploying reserves to deal with Soviet attacks.

Hitler's failure to allow Field Marshal Busch, Commander of Army Group Center, to execute an elastic defense based on withdrawal behind the Dnieper and Berezina rivers resulted in the destruction of Army Group Center. The shortening of the front by 160 Kilometers by withdrawal to the Berezina river would have created reserves and better defensive conditions to meet the Soviet summer offensive. However, Hitler absolutely forbid this withdrawal and forced Army Group Center to conduct a defense on a vastly overextended front which resulted in enormous material and personnel losses.

The loss of air superiority by the Luftwaffe to the Soviet Air Force was critical to the collapse of the German Army in the East. The Luftwaffe from the beginning of the Russian campaign was already overextended by fighting on several fronts. This situation only became worse as the summer of 1944 approached. The loss of 
air power because of dispersion to several theaters prevented the concentration of strength in the East to wage strategic warfare. The failure to wage strategic warfare from the air against the Soviet sources of armaments allowed the Soviet production of tanks, aircraft and artillery to continue without interference. Thus, the Luftwaffe was forced to destroy Soviet military equipment in the field instead of in the factories. The end result was the Luftwaffe was increasingly forced into a defensive role on the Eastern Front. The Soviet Air Force attained numerical superiority over the Luftwaffe by the end of 1943 and this had an enormous impact on German ground forces which were mostly on the defensive on the ground. Previously, the Germans had enjoyed air superiority or at least air equality but by 1944 the Luftwaffe had fallen into a numerically inferior position compared to the Soviet Air Force. The Soviets had more than a 7:1 advantage in aircraft by the summer of 1944 . The Soviet advantage was due mostly to the fact that $56 \%$ of the Luftwaffe was engaged in the West against the Anglo-American allies. Thus, German soldiers were forced to defend themselves against attacks from the air and on the ground. The Soviet use of airpower in support of its army proved effective with the Germans suffering heavy losses as a result of continuous air attacks.

Lend-Lease aid to the Soviet Union played a key role in the defeat of the German Army in the East during the summer of 1944. The U.S.S.R. had received more than 6 million pairs of boots by the summer of 1944 which put the Red Army in marching boots. Lend- 
Lease food was of significant aid to the Red Army since it provided one pound of concentrated ration per day for 6 million soldiers for the length of the entire war. Lend-Lease motor vehicles provided perhaps the most significant aid to the Red Army by motorizing it. The intensive motorization of the Red Army with approximately 500,000 Lend-Lease trucks provided the Red Army with superior mobility compared to the Wehrmacht. Superior mobility enabled the Red Army to outmaneuver the German Army and drive deep into the rear areas causing encirclements and major disruptions which resulted in a series of German defeats.

Lend-Lease truck shipments not only provided the Red Army with the necessary mobility to outflank non-motorized German formations but also allowed the Soviets to de-emphasize vehicle production. The Soviets were able to concentrate on tank and aircraft production since the United States provided the bulk of the Red Army's trucks, jeeps and motorcycles thru Lend-Lease aid. The concentration on tank production permitted huge numbers of tanks to be produced which dwarfed German tank production. Soviet production of tanks and self-propelled guns amounted to 112,952 compared to the German production of 46,742 vehicles. Thus, LendLease aid proved significant to the defeat of the German Army in the East during the summer of 1944.

The second front played a crucial role in tying down German mobile reserves thereby depriving the Wehrmacht of significant mobile formations to meet the Soviet summer offensive in the East. The Wehrmacht deployed $51 \%$ of its mobile formations and $42 \%$ of 
its non-mobile formations in the West. Germany's two-front war by the summer of 1944 was depriving the Wehrmacht of necessary forces to concentrate in the East to meet the advances of the Red Army. The Eastern Front was deprived of sufficient mobile reserves as a result of the Anglo-American second front. This created a situation where the Wehrmacht could not achieve a stalemate on the Eastern Front because it had been weakened to meet the Anglo-American second front. The mobile reserves constituted elite German formations which would have been highly effective if used against Soviet breakthroughs on the Eastern Front during the summer of 1944. However, half of these reserves were tied down in the West to meet the Anglo-American second front.

The German Army in the East had managed to maintain most of its defensive positions on the Belorussian sector during the winter of 1944. The German defensive success had been achieved by the use of mobile reserves and the shifting of troops in the lines along lateral roads and railways to prevent Soviet breakthroughs. German commanders also managed to coordinate their artillery and concentrate it against Soviet attacks. Soviet attacks at a superiority of 10:1 were common and failed against German defensive positions. Soviet tactical errors on the Belorussian front included failure to make diversionary attacks against extended sectors of the front; attacks renewed at identical sectors of previous attacks; and a failure to coordinate their artillery in the breakthrough sectors. 
Soviet operational planning for the summer offensive of 1944 corrected the deficiencies noted in the winter offensives against the Belorussian front during the winter of 1944 . Soviet planning called for six separate breakthrough areas to dismember the German defenses along the entire length of Army Group Center. The breakthrough areas on each of the four Soviet fronts were compressed so that the average total divisional frontage was 5.8 kilometers compared to 24 to 32 kilometers for the German divisions. However, the frontage on the breakthrough sectors was compressed further to 1.5 kilometers per division to achieve not just overwhelming numerical superiority over the Germans but bring a level of mass to bear against German defensive positions which would cause them to disintegrate under the weight of the attack. The depth of the operation was extended for an advance of 550 to 600 kilometers and the total number of divisions was increased to 166 divisions. A total of 11 armies were deployed against Army Group Center and two combined armies were assigned to make each penetration. The four fronts deployed to attack Army Group Center were reinforced with approximately 30 additional divisions prior to the start of the summer offfensive. Soviet numerical superiority was overwhelming with 166 divisions attacking approximately 49 German divisions. Soviet superiority was definitive in every category. The Soviets possessed the following margins of superiority: $1.7: 1$ in troops; $1.8: 1$ in artillery and mortars; 1.6:1 in tanks and assault guns and 4.9:1 in operational aircraft. Thus, Soviet operational planning established a plan with 
the key elements necessary to dismember Army Group Center as the first step in its offensive operations for the summer of 1944.

The collapse of Army Group Center was the most significant event of the summer of 1944. It marked the turning point on the Eastern Front during the summer of 1944. Army Group Center was the bulwark of the Eastern Front and once it was smashed the entire Eastern Front collapsed. Army Group Center consisted of the following: 3rd Panzer Army, 4th Army and 9th Army.

The Soviet offensive on June 22, 1944 began first in the north against the 3rd Panzer Army and 4th Army. The 3rd Panzer Army's sector was critically overextended in the LIII Army Corps sector which constituted the Vitebsk enclave. The LIII Army Corps was completely encircled on June 24, 1944 within the Vitebsk sector and it capitulated on June 27, 1944. The IX Army Corps of the 3rd Panzer Army was battered and pushed back in the direction of Army Group North. The VI Army Corps was pushed to the south in the process of the Soviet encirclement of the LIII Army Corps. On June 25, 1944, the VI Army Corps was removed from command of the 3rd Panzer Army.

The 4th Army came under attack on June 22, 1944. The 4th Army had the strongest forces deployed to defend its sector of the front. The 4th Army retreated slowly under Soviet attack and was not completely encircled until July 1, 1944.

The 9th Army was attacked on June 23, 1944 which was one day after the major assaults against 3rd Panzer Army and the 4th Army. However, the main weight of the Soviet attack did not hit 
the 9th Army until June 24, 1944. The encirclement of the 9th Army and Bobruisk was completed on the night of June 26-27, 1944.

Thus, Army Group Center disintegrated under a series of Soviet encirclements which dismembered the Army Group and resulted in the loss of Belorussia and the annihilation of 28 German divisions in less than two weeks. The resulting losses had to be replaced primarily by weakening the other Army Groups on the Eastern Front: Army Group North, Army Group North Ukraine and Army Group South Ukraine. The weakening of these Army Groups was followed by a Soviet offensive against each Army Group in turn which brought about the collapse of the Eastern Front.

The Soviets launched the Lvov-Sandomierz offensive with the 1st Ukrainian Front against Army Group North Ukraine on July 13, 1944. Soviet goals in this operation were to clear the Ukraine and occupy southern Poland. The Soviets had massed sufficient numerical superiority to achieve their objectives. The Germans attempted to respond to the Soviet use of mass by tactical flexibility in meeting the weight of the Soviet attack. However, the Soviet use of mass on narrow sectors was consistently successful and the Soviets drove into the 4th Panzer Army and the 1st Panzer Army on the flanks of the XIII Army Corps. The XIII Army Corps began to disengage during the night of July 16-17, 1944 because of the deteriorating situation along its flanks. However, the XIII Army Corps withdrawal movement was too slow and the Corps was completely encircled on July 18, 1944. On July 
20, 1944, 85,000 men were compressed into a pocket west of Brody. The XIII Army Corps ceased to exist as an effective combat formation on July 22, 1944 under the tightening ring of Soviet encirclement. There were only a few units of the XIII Army Corps which managed to escape the Brody pocket. German losses amounted to five divisions and approximately 25,000 to 30,000 soldiers. The losses experienced by Army Group North Ukraine were mostly replaced by transfers from Army Group South Ukraine which weakened this Army Group further.

The final chapter in the collapse of the German Army in the East during the summer of 1944 was the destruction of Army Group South Ukraine. The Soviet methods employed against Army Group Center and Army Group North Ukraine were essentially the same methods used against Army Group South Ukraine with equally devastating effects on German defensive positions. Army Group South Ukraine had served as the reserve pool for the other Army Groups throughout the summer by continuous transfers of divisions to Army Group Center and Army Group North Ukraine to replace their losses. Consequently, Army Group South Ukraine was depleted of reserves and substantially weakened prior to the Soviet offensive against it on August 20, 1944.

German intelligence failed to provide concrete direction about Soviet intentions toward Army Group South Ukraine. First, Foreign Armies East indicated that an offensive was unlikely as of July 30, 1944. Later, Soviet activity was recognized on the Rumanian Front stretching from Tiraspol to the Carpathians. 
Nevertheless, Foreign Armies East despite significant increases in Soviet activity maintained the view that a major offensive against Army Group South Ukraine was unlikely as late as August 15, 1944. However, local attacks were forcast with the intention to prevent the further transfer of German divisions to the central front. It was not until August 19, 1944 which was the day preceeding the main offensive that intelligence estimates of Soviet intentions underwent a major revision, but too late to help Army Group South Ukraine.

The issue of Rumanian reliability was questioned by Colonel General Schorner, Commander of Army Group South Ukraine, with the result that he was transferred on July 23, 1944 to command Army Group North. Meanwhile, optimistic reports were filtering through OKW overestimating Rumanian reliability. The loyalty of the Rumanian people and the Rumanian Army was confused with the loyalty of Marshal Antonescu. Defensive plans were based upon the reasonable expectations of Rumanian reliability. Therefore, a withdrawal to more secure defensive positions on the Pruth river was not permitted.

The Soviets launched the Jassy-Kishinev Operation on August 20, 1944. The two main attacks were launched against the area south of Tiraspol and northwest of Jassy. Deep breakthroughs occurred on the Rumanian held sectors. Soviet forces drove deep into the German rear area surrounding the German 6th Army and other elements of Army Group South Ukraine. Marshal Antonescu was arrested on August 23, 1944 and King Michael announced on 
state radio that Rumania would seek an armistice. The Rumanians leaving the war created large holes in the defensive line and the German position in Rumania turned into a catastrophe. However, the situation even became worse with the German decision to attack Bucharest on August 24, 1944 in an attempt to crush the Rumanian putsch. The Germans failed to crush the revolt against Antonescu in Bucharest by not deploying sufficient forces for this task and this resulted in the new Rumanian government declaring war on Germany and bringing the Rumanian Army into the war on the Soviet side. The end result for Army Group South Ukraine was the destruction of 5 army corps headquarters, 18 divisions and the almost total loss of 3 other divisions.

Finally, the significance of the German defeats in the East during the summer of 1944 can be demonstrated quantitatively. German losses in troops, armored vehicles, non-armored vehicles, generals and divisions exceeded the losses in the West. German armored vehicle and non-armored vehicle shipments were far greater to the East to replace its greater losses than to the West. The only area where German losses were higher on the AngloAmerican Fronts was in aircraft losses. The Luftwaffe received $75 \%$ of its losses in the West compared to $25 \%$ in the East. Nevertheless, the German Army received the bulk of its losses during the summer of 1944 in the East which made the Eastern Front the predominant front even after the allied landing in France on June 6, 1944. 
Therefore, the analysis of data from the summer of 1944 will show that the collapse of the German Army in the East was the most decisive military event during the summer of 1944 based upon the military losses suffered by the German Army and was the result of the following factors: German Intelligence failures; German defensive doctrine; loss of German air superiority; Lendlease aid to the Soviet Union; German mobile reserves committed in the West; Soviet numerical superiority; and Soviet offensive doctrine and tactics.

The collapse of Army Group Center, the destruction of the XIII Army Corps in Army Group North Ukraine and the destruction of Army Group South Ukraine will be examined in detail day by day in order to delineate the significant details of the collapse of the German Army in the East during the summer of 1944. These three events constitute the decisive defeats which resulted in the retreat of the German Army from the Soviet Union in the summer of 1944 and the subsequent advance of the Red Army into Eastern Europe. 


\section{NOTES TO CHAPTER I}

1 Alex Buchner, Ostfront 1944 (Stuttgart: Motorbuch Verlag, 1988); Hermann Gackenholz, "The Collapse of Army Group Centre in 1944" Decisive Battles of World War II: The German View ed. H.A. Jacobsen and J. Rohwehr (New York: G.P. Putnam's Sons, 1965); Rolf Hinze, Das Osttront Drama 1944 (Stuttgart: Motorbuch Verlag, 1987); Rolf Hinze, Der Zusammenbruch der Heeresgruppe Mitte im Osten 1944 (Stuttgart: Motorbuch Verlag, 1980); Gerd Niepold, Battle For White Russia: The Destruction Of Army Group Centre June 1944 (London: Brassey's Defense Publishers, 1987). 


\section{CHAPTER II}

\section{THE FAILURE OF GERMAN MILITARY INTELLIGENCE TO PREDICT THE SCHWERPUNKT OF THE SOVIET SUMMER OFFENSIVE IN 1944}

The failure to predict the Soviet summer offensive in 1944 was not the fault of Adolf Hitler but a failure of German military intelligence. Foreign Armies East under Colonel Reinhard Gehlen was responsible for intelligence estimates of Soviet military intentions, operations and capabilities. Gehlen was appointed head of Foreign Armies East (Fremde Heere Ost) on April 1, 1942. He introduced reforms which produced a new organization which provided a rapid flow of intelligence data from the front to his department. Gehlen established two parallel channels of intelligence. The first channel followed the military chain of Ic or intelligence officers at each command level and the second channel consisted of the Abwehr chain with crossovers at each level.1

The overall intelligence network on the Eastern Front (see Figure 1) produced accurate predictions that had increased the operational and defensive capabilities of the Wehrmacht in countering and defeating the Red Army in the past. The defense of Osuga in the Ninth Army sector of Army Group Center in November 
of 1942 delineated how successful operational military intelligence can be in contributing to defensive victories. ${ }^{2}$ In the summer of 1944, the German Army needed a clear answer to these questions: Where and when would the main offensive occur and how many forces would be involved? The answers to these questions were critical to its survival in the East.

The lack of reserves ruled out the development of more than one center of defensive resistance which meant the Germans had only reserves to counter one main Soviet effort. However, the Soviets had learned how to confuse German intelligence by 1944 and Foreign Armies East made predictions about the major Soviet offensive in the summer of 1944 that proved to be false. The results of these inaccurate predictions caused a disaster of unprecedented scale: the destruction of Army Group Center.

\section{FOREIGN ARMIES EAST AND OBERKOMMANDO DES HEERES}

On March 30, 1944, Gehlen's intelligence summary predicted further Soviet offensive operations against Army Group A which was designated Army Group North Ukraine on April 5, 1944. Gehlen stated:

The present situation on the eastern front is overshadowed by the anticipated general enemy offensive against our Army Groups A and South. As it proceeds, a more menacing situation than ever before has emerged on the eastern front, and in the not too distant future this may result 
in far-reaching political, military and economic repercussions on the rest of the war in Europe. ${ }^{3}$

Colonel Gehlen was accurate in his assessment on March 30, 1944 that there would be a longer operations pause before the next operations commenced. 4 However, his prediction that the enemy had been recognized to favor the operation of an effective thrust against the San and Weichsel rivers and also against Rumania with the bulk of his forces proved to be incorrect in the short range assessment (see Figure 2) but accurate in the long range view of the strategic situation on the eastern front. 5

On April 19, 1944, Gehlen postulated the next Soviet objective based on the disposition of Russian forces to be the line Stanislau - Przemysl - Lubin - Brest. 6 He predicted that the enemy upon reaching this line would advance in a southwestern direction through Slovakia into the Balkan area or drive in a northwestern thrust toward Warsaw and Danzig. ${ }^{7}$ Foreign Armies East (Fremde Heere Ost, FHO) issued a "Beurteilung der Feindlage" (enemy situation assessment) on May 3, 1944 which confirmed Gehlen's view of the situation on April 19, 1944. FHO forcasted two possible Soviet offensives. One possible offensive was predicted to cross the line Kovel-Lutsk advancing through Warsaw to the Baltic coast thereby cutting off Army Groups North and Center. The other offensive forecasted was a possible thrust through Rumania, Hungary and Slovakia into the Balkans (see Figure $3 \& 4$ ). 8 FHO noted that the northwestern offensive toward the Baltic coast would require a high level of tactical efficency. Therefore, FHO 
concluded that the most probable main effort by the Red Army would be directed toward the south where the weak axis allies could be exploited and Soviet hegemony over the Balkans be established. ${ }^{9}$

Gehlen confided to his deputy Gerhard Wessel that the Soviet High Command would most likely choose the lower risk offensive based on their past behavior when confronted with such options. Gehlen concluded that the Soviets would attempt to cross the Beskiden moutain range or the Carpathians and in conjunction or as an alternative advance between the eastern border of the Carpathians and the Black Sea coast in the direction of the Balkans and the Mediterranean.10 The attack through Warsaw to the Baltic coast was seen as a decisive operation that would if successful have major consequences on the war in the east. However, such an operation would encounter fierce resistance in the territory of the Reich. Therefore, Gehlen concluded that the Soviet main effort would be in the south (see Figures $3 \& 4$ ).

On May 10, 1944, FHO revised their estimate of enemy offensive preparations. Heavy rail traffic and signs of a buildup were observed in the Kovel-Ternopol area 11 Foreign Armies East noted in their intelligence bulletin:

The limitation of radio transmissions that occurred on 9 May on an unprecedented scale over the entire Eastern Front, as we know from experience, could indicate that preparations for the enemy offensive may be nearing completion. That is why it is possible to consider the possibility that the enemy will initiate his offensive in the known regions within the nearest 
future. This is most likly to occur in the area of the Army Group North Ukraine and along the right flank of the Army Group Center. ${ }^{12}$

FHO on May 12, 1944 was now predicting two offensives according to the Kriegstagebuch (war diary) of the operations officer of Army Group Center. The main effort was still to be in the south between the Carpathians and the Black Sea, but another offensive force was assembled between the Carpathians and the Pripyat marshes to attack on the axis Lvov, Lublin and Brest. ${ }^{13}$ (see Figures 3 \& 4)

Chief of Staff at OKH, Generaloberst Kurt Zeitzler recommended the buildup of reserves in Army Group North Ukraine to meet the anticipated offensive projected by FHO. These forces were taken from Army Groups North and Center to develop an Abwehrschwerpunkt. The OKH Kriegsgliederung of June 15, 1944 showed the following Panzer and Panzer Grenadier Divisions in Army Group North Ukraine:

OKH Reserve: 20th Panzer Division Army Group

Reserve:

9th SS Panzer Division, 10th SS

1st Hungarian

Army:

Panzer Division, 16th Panzer Division

1st Panzer

Army:

2nd Hungarian Panzer Division

1st Panzer Division, 7th Panzer

Division, 8th Panzer Division

17th Panzer Division, 20th Panzer

Grenadier Division

4th Panzer

Army:

4th Panzer Division, 5th Panzer Division. ${ }^{14}$

The 9th SS and 10th SS Panzer Divisions were transferred to the Western Front in the middle of June but still appear on the $\mathrm{OKH}$ 
Kriegsgliederung as of June 15th. However, both divisions received orders to leave the Eastern Front on June 12th and the 9th SS Panzer Division reached the Franco-German border on June 16th. 15 The 20 Panzer Division was also later transferred to the 9th Army in Army Group Center on June 16th because of enemy concentrations in the Ninth Army sector. Nevertheless, the bulk of the Panzer and Panzer Grenadier Divisions on the Eastern Front remained in Army Group North Ukraine.

Army Group Center, the bulwark of the Eastern Front, had insignificant mobile force by contrast to Army Group North Ukraine. The OKH Kriegsgliederung of June 15, 1944 delineated the following mobile force in Army Group Center:

OKH Reserve: Panzer Grenadier Division "Feldherrnhalle"

3rd Panzer

Army:

4th Army:

9th Army:

2nd Army:
No mobile reserves 18th Panzer Grenadier Division, 25th Panzer Grenadier Division No mobile reserves No mobile reseves. ${ }^{16}$

The situation only improved on June 16th when the 20 Panzer Division was transferred to the 9th Army. 17

This shifting of mobile reserves on the Eastern Front was based on the intelligence estimates that developed during May and June. Zeitzler suggested shifting the LVI Panzer Corps from 2nd Army in Army Group Center to Army Group North Ukraine on May 10th and this suggestion was followed by a formal request by Field Marshal Model for the transfer of the LVI Panzer Corps to his army 
group. On May 20th Hitler approved Model's request and the LVI Panzer Corps was transferred to Army Group North Ukraine which stripped Army Group Center of its panzer reserves. ${ }^{18}$ The 4 th and 5th Panzer Divisions were lost with the transfer of the LVI Panzer Corps and the 20 Panzer Division was also transferred separately to Army Group North Ukraine.19 Army Group Center was left with only three Panzer Grenadier Divisions until June 16th when the 20th Panzer division was returned. This lack of mobile reserves was to be significant to the defeat of Army Group Center. Faulty intelligence was to play a major role in the placement of the critical Panzer reserves in the wrong sector of the Eastern Front to meet the Soviet summer offensive.

On May 21, 1944, German Intelligence Bulletin No. 1 stated:

The continuing animated rail traffic along sectors occupied by both army groups, along with partially known transportation of tanks by rail, makes possible a conclusion concerning the continuation of major enemy measures aimed at the reinforcement of the troops and the shipment of material. According to the enemy's current position it is possible to establish that the enemy is very thoroughly preparing for his future operations, the main goal of which still consists of the "Balken resolution".20

The 9th Army in Army Group Center began to report an enemy buildup north of Rogatchev on May 30th.21 Despite 9th Army reports, the German Intelligence Bulletin of May 30, 1944 noted:

Aerial reconnaissance data at the present moment indicate very heavy railway traffic around Kiev, 
Dnepropetrovsk, Rovno, and Ternopol, which confirm the opinion concerning the movement of Crimean soyedineniya to the front. The movement is primarily toward the vicinity of Balta, Ternopol, Rovno, and Kovel, as a result of which the assumption to the effect that these forces are being increasingly confirmed. 22

Both Keitel and Jodl were convinced that the attack would come in the south. Keitel in May 1944 stated:

The situation has stabilized on the Eastern Front. We can feel confident that the Russians will not be able to launch an assault for some time. Proceeding from data pertaining to the regrouping of enemy forces and the overall military and political situation, it is necessary to consider that the Russians probably will concentrate their main forces in the southern sector of the front. They are presently incapable of fighting along several main directions. ${ }^{23}$

The Chief of Operations of the Oberkommando der Wehrmacht (OKW), General Jodl, declared at the Nuremburg trial:

that the Russian attack would take place in the southern sector, in the direction of Rumanian petroleum, which is why most of the tank divisions were concentrated by us in the vicinty of the southern army groups. ${ }^{24}$

The situation began to change in June and signs of an attack on Army Group Center began to emerge. On June 3, 1944, FHO discounted the activity opposite Army Group Center as "apparently a deception."25 The enemy situation report of June 4, 1944 indicated that "at any time the enemy could strengthen his local concentrations on the eastern front by switching his very considerable reserves." $26 \mathrm{OKH}$ finally began to acknowledge some 
form of offensive operations directed at Army Group Center in the Intelligence Summary of June 10, 1944:

Even if there is no reason to change the opinion that the attacks to be expected on Army Group Center will only be secondary operations in the framework of the Red Army's major offensive as a whole, account must be taken of the concentrations which are still continuing opposite Army Group Center. These place the enemy in a position to develop centers of effort with a penetrative power which, given the relative strenghts of the two sides, must not be underestimated.27

Despite the radio silence that descended along the Russian side of the front, German Signal Intelligence was still able to intercept critical information. Captain Krickendt sent a report to OKW on June 12, 1944 concerning a radio intercept about a large sabotage mission from the 3rd Belorussian Front to the "Grischin" Partisan Regiment:

The enemy has used the lull on the Soviet-German front to increase the redeployment of troops and technical material over the railroads. With the objective of disruption of the enemy's transfers of troops, I order all the forces of your units to conduct mass destruction of railroad tracks in the rail war(Schienenkrieg) and in the Orsha Borisov railroad sector detonate 1000 sections of track. You are to start immediately with the execution of this operation and keep the demolitions secret. The first attack is to be conducted with continuous blows to achieve a total neutralization of the enemy's troop redeployments. Further orders will not be given. Proceed independently as heretofore. 28

This information indicated a positive sign of an impending offensive on Army Group Center. The Soviet High Command, Stavka 
had given the same all-out rail war order to partisans on July 14, 1943 to commence operations on July 20-21, 1943 to coincide with the offensive against Orel and Briansk.29 Therefore, intelligence alarms should have jolted the $\mathrm{FHO}$ and the $\mathrm{OKH}$ to an immediate reassessment of Soviet offensive intentions. Furthermore, Signal Intelligence detected the presence of new armies; aerial reconniassance units noted strong new artillery units along the entire front of Army Group Center; and prisoners reported the appearance of assault formations in the rear of the enemy front. 30

The situation assessment by FHO on June 13, 1944 indicated more than one offensive developing on the Eastern Front. However, the Schwerpunkt that was seen as immediately forthcoming was once again expected by the FHO in the area between Kowel and the Carpathians, (see Figures $5 \& 6$ ) but the FHO also predicted with. certainty diversionary attacks on Army Group Center or on the Rumanian northern border. ${ }^{31}$ A larger attack against Army Group Center was considered conceivable. An offensive from the GomelSmolensk area with the objective of Minsk was possible. In fact, several reports indicated just such an enemy intention. FHO predicted that if the enemy should actually conquer the area Mogilev-Orsha-Vitebsk that more than enough forces would remain available to conduct a further advance toward Minsk.32 Therefore, nine days before the Soviet offensive the intelligence assessment that the Schwerpunkt of operations would be against Army Group North Ukraine appear highly questionable. 
Gehlen claims in his memoirs that by early June "all the indications were that they planned a major offensive against Army Group Center, commanded by Field Marshal Busch, which was defending Poland and East Prussia."33 However, the FHO reports during June prior to the offensive continued to predict the main offensive to be against Army Group North Ukraine with a secondary offensive against Army Group South Ukraine (See Figures $5 \& 6$ ). Attacks against Army Army Group Center still were viewed as secondary or feints to confuse the Germans as to real direction of the major attack. Gehlen on June 13, 1944 recognized the increased Soviet strength opposite Army Group Center:

Particular attention should be paid to the areas southeast and east of Bobruisk, on both sides of Chausey, along the highway northeast of Orsha, and on both sides of Vitebsk. ${ }^{34}$

Neverthless, Gehlen' s FHO ignored these positive signs of an offensive and treated them as only secondary to the expected Schwerpuhkt against Army Group North Ukraine.35

Gehlen neglected to mention in his memoirs the error of predicting the main Soviet offensive against Army Group North Ukraine instead of Army Group Center. He merely defends his assessment that the operation was to take place in phases:

As I had predicted on June 13, a second phase of the Soviet offensive began a few days after the first, with a general attack on Lemberg (Lvov). ${ }^{36}$ However, the holding or diversionary attacks that had been predicted against Army Group Center were in actuality the 
Schwerpunkt of the Soviet summer offensive and Gehlen and the FHO had failed in their prediction of Soviet offensive plans which had disastrous effects on the Eastern Front.

The uncertainty of FHO intelligence estimates was noted in the German Intelligence Bulletin of June 13, 1944 which indicated that the German command had as a result of Russian radio silence "lost one of the most important and reliable intelligence sources." ${ }^{37}$ The uncertainty was reflected further in the same bulletin which stated:

After it became almost completely impossible to carry out radio reconnaissance difficulties occured in the determination of the position occupied by enemy forces. At present aerial reconnaissance is rather difficult because of the constantly increasing Russian defenses. That is why details pertaining to the strategic deployment of the enemy, which is nearing completion, cannot be determined. 38

Nevertheless, OKH on June 14,1944, called a conference of army group and army chiefs of staff to brief them on the forthcoming Soviet offensive operations. Zeitzler and Chief of operations of $\mathrm{OKH}$, General Heusinger impressed upon the chiefs of staffs that the Soviet offensive would be against Army Group North Ukraine and not Army Group Center. The attacks against Army Groups Center and South Ukraine were merely preliminary and secondary operations. OKH was sure that they would be able to handle the Soviet offensive. The expression used was: "zum ersten Mal Schwerpunkt gegen Schwerpunkt."39 Gehlen was also present at the conference and warned that "simultaneous attacks on Army 
Groups Center and South Ukraine could be expected as preliminaries to the big offensive against Army Group North Ukraine." 40

Army Group Center presented clear evidence that strong Soviet forces were massing opposite it. No other front including Army Group Norh Ukraine could present such infallible indicators of offensive preparations on their respective fronts. ${ }^{41}$ However, Chief of Staff of OKH, General Zeitzler informed General Krebs, Chief of Staff of Army Group Center, that according to Gehlen the following operations were foreseen:

Phase 1 as a simultaneous attack on Army Groups South Ukraine and Centre, followed after a certain interval by the main operation--an offensive against Army Group North Ukraine. ${ }^{42}$

Therefore, despite offensive indicators against Army Group Center; $\mathrm{OKH}, \mathrm{FHO}$ and Hitler were fixated upon the offensive in Galicia. $\mathrm{OKH}$ did at least recognize the threat to the 9th Army at Bobruisk and the 20th Panzer Division was transferred to Army Group Center from Army Group North Ukraine.

Gehlen's assessment of the enemy's intentions had a direct impact upon reserve deployment as indicated by the FHO memorandum of June 17, 1944:

In connection with the withdrawal of certain German formations from Army Group North Ukraine's area, the briefing given to the Chief of staff on 17 June 1944, on the instructions of the Head of Branch, was this. By and large, the centre of effort of future Soviet offensive operations remains directed against Army Group North Ukraine. The strong infantry and tank forces concentrated here under the command of Marshal Zhukov 
will presumably be required to make the main thrust of the enemy operations as a whole, with the inital objectives in the Przemysl-Lublin area or thereabouts. This view, confirmed by numerous reports from higher intelligence agencies (Abwehrmeldungen), remains unchanged despite the enemy offensive preparations recently observed opposite Army Group Centre... 43

Thus, Gehlens analysis and recommendations which provided the basis for assumptions about Soviet operations were in error and resulted in the deployment of the critical mobile reserves behind the wrong sectors of the Eastern Front instead of Army Group Center. Therefore, the mobile reserves were not available to prevent the catastrophe in Army Group Center.

On June 19, 1944, more indications of an attack on Army Group Center developed. Marshal Zhukov was confirmed as having taken command of the southern part of the enemy front by a captured pilot. POW's reported having been indoctrinated about the necessity of liberating occupied Belorussia as the first objective of the forthcoming offensive.44 Fremde Luftwaffe Ost (Foreign Air Forces East) sent a report to OKW giving the statement of 1st Lieutenant Kusmenkow of the Moscow Guard Fighter Regiment of the 3rd Air Army.45 Kusmenkow revealed that all preparations of the 3rd Air Army had to be complete by June 20th for the impending offensive that would follow within a few days. The first objective was Polotsk in an attempt to encircle Vitebsk rather than frontally assaulting it. The Air Army was to operate in support of the army formations. These details were confirmed by captured written orders. Kusmenko reported strong artillery and Panzer forces 
assembling opposite Polotsk. The 3rd Air Army was reported as having to abandon good air bases in the rear to concentrate on less favorable forward air bases to achieve the closest possible concentration in the area of Polotsk. Polotsk was designated as the next objective for massed air attacks by the 3rd Air Army.

Meanwhile, Field Marshal Keitel of OKW was giving a briefing at Sonthofen and announced that he was certain that the Russians would not mount a large scale offensive on Army Group Center. He believed that an offensive would occur in the south towards Lvov and then Rumania. 46

The night of June 19, 1944 brought about a new perspective at FHO. The partisans in Belorussia during the night had conducted the most massive railroad demolition operation recorded to date. 10,500 demolitions interrupted all railway traffic to the west of Minsk.47 The Germans managed to disarm 3500 explosives on the rail lines but the material damage done was so great that rail movement was paralyzed for 24 hours and longer in some areas. 48 The operation of double tracks was no longer possible. One track had to be disassembled to repair and maintain the second track. The demolitions conducted on the night of June 19-20th exceeded the total number of demolitions for the entire month of May which amounted to 7000.49

The FHO Intelligence Report of June 20, 1944 stated:

The question of the center of effort of the offensive had to be reviewed in the light of the wave of demolitions in Army Group Center's rear during the 
night of $19 / 20$ June, focused as this was on the axial rail links through Luninets, Borisov and Molodechno; and that there had been several mentions of 22 June as the date for it. Preparations for the offensive were reported to be complete on 3rd Panzer Army's and the German 4th Army's sectors, but still in progress opposite the German 9th Army (See Figure 7). 50

OKH and Oberkommando der Luftwaffe (OKL) on June 20th noted the concentration of air power along the front. OKL calculated 4000 Soviet aircraft concentrated along the central front.51 The long-range air forces continued to be deployed in the south. OKL asserted that "clearly attacks must be seen as possible anywhere but particularly probable in the south." OKH noted the strong ground-attack and fighter units in the Gomel area and west of Smolensk. Such concentrations indicated that the enemy intended to pursue objectives in great depth. These air units were intended for close air support of mechanized formations. The number of aircraft available permitted the enemy to provide massive air support along all primary thrust lines. The air units were noted to have completed all preparations as of of June 20 , 1944.52

On June 21, 1944, OKW, OKH and Army Group Center were alerted by Lt. Colonel Scmalschlaeger in the Abwehr that known enemy agents and partisans had received orders from the 3rd Belorussian Front on June 19th indicating impending offensive operations. In addition to destroying rail road tracks along the Orsha-Borisov line, they were to "report by radio transport trains, military concentrations and possible targets for the Soviet Air 
Force."53 This indicated the direction of Soviet air operations as being behind Orsha, Vitebsk and Mogilev. Previously, Polotsk had been identified as a target for massed air attacks. Thus, Army Group Center emerged as the primary target of impending Soviet Air offensive operations, but FHO clung to the belief that the major offensive would occur in the south.

FHO issued a report on June 21, 1944 warning of impending attack:

The lively enemy reconnaissance activity and local probing attacks, coupled with information from signals intelligence, indicated that the enemy facing Army Group Center was ready to attack. 54

However, this attack was still viewed as only preliminary or secondary.

The First Baltic and Third Belorussian Fronts started the offensive on June 22, 1944 by attacking northwest and southeast of Vitebsk in the sector of 3rd Panzer Army. The German 4th Army was also attacked by the Third and Second Belorussian Fronts. However, there were no attacks against 9th Army near Bobruisk and only three minor probing attacks occurred in the sector of the 2 nd Army. 55

On June 23, 1944, OKH still had not determined the Schwerpunkt of the Soviet offensive. Soviet Breakthroughs had occurred in the 3rd Panzer and 4th Army sectors; 9th Army was experiencing battalion and regimental attacks; and 2nd Army reported no attacks. ${ }^{56}$ FHO perceived the shifting attacks as a 
possible deception since Soviet attacks were continuing against Army Group North Ukraine.

However, On June 24th, the attacks against Army Group North Ukraine abated and the question of whether these attacks in conjunction with the attacks against Army Group Center were in fact feints remained unanswered.57 Army Group Center reported no Soviet activity against 2nd Army. But the 3rd Panzer Army, 4th and 9th Armies reported major Soviet breakthroughs and serious problems maintaining their flanks against continuous Soviet attacks. Vitebsk was encircled and contained 5 German divisions and elsewhere the front was collapsing. Finally, $\mathrm{OKH}$ realized too late on June 25th that the Soviet offensive against Army Group Center was the main offensive.

One central problem that plagued the Germans prior to the offensive was the failure to identify entire Soviet armies. This failure caused underestimation of forces on the central sector and overestimation of enemy capabilities on the southern sectors. FHO had not identified the 2nd and 5th Guards Tank Armies on the central front. FHO still believed their location was north of Jassey opposite Army Group South Ukraine. But the 2nd Tank Army was near Smolensk with the 3rd Belorussian Front. ${ }^{58}$ FHO had received a report from a reliable source that Marshal Rotmistrov, Commander of the 5th Guards Tank Army was seen near Yartsevo (northeast of Smolensk). 59 However, FHO discounted their source since German Intelligence had not noted any movements of the 5th Guards Tank Army from its area north of Jassey. The problem was that German 
Intelligence could not ascertain with any accuracy the location of Soviet strategic reserves. The 8th Guards Army was located on the 3rd Ukranian Front east of Tiraspol by German Intelligence, but it had actually been transferred to the 1st Belorussian Front. The 2nd Guards and 51st Army were supposed to be in the Crimea according to German Intelligence. However, the 2nd Guards Army was deployed near Smolensk and the 51st Army was near Gomel.60 The 1st Polish Army went undetected in the area east of Kovel. FHO continued to delineate all six tank armies in the area between Ternopol and the Black Sea. ${ }^{61}$

Thus, FHO and $\mathrm{OKH}$ made false projections about the Schwerpunkt of the Soviet summer offensive based upon their assessment of the deployment of the six tank armies. On May 3, 1944, FHO showed the deployment of the bulk of the Soviet tank corps in the first and second Ukranian Fronts (see figure 8). The FHO Uebersicht ueber die Komandobehoerden der Roten Armee for May 18, 1944 delineated a Soviet order of battle with all six tank armies in the south.62 The 3rd Guards Tank Army, 4th Tank Army and 1st Tank Army were subordinated to the 1st Ukranian Front. The 5th Guards Tank Army, 2nd Tank Army and 6th Tank Army were located with the 2nd Ukranian Front. FHO failed to detect the movement of the 5th Guards Tank Army and the 2nd Tank Army out of the 2nd Ukranian Front.

On May 28, 1944, FHO noted that the XXIX Tank Corps of the 5th Guards Tank Army had been placed in reserve which meant that all the elements of the 5th Guards Tank Army were now in reserve 
except for the 5th Guards Headquarters. ${ }^{63}$ The XVIII Tank Corps and the $\vee$ Guard Mechanized Corps of the 5th Tank Army were already noted in reserve on May 18, 1944.64 The 2nd Tank Army was noted as deployed with the 2nd Ukanian Front on May 18,1944. On May 28, 1944, the subordinate elements of the 2nd Tank Army: III Tank Corps and XVI Tank Corps were noted to have been placed in reserve on the 2nd Ukranian Front.65 FHO noted on June 7, 1944 that that the entire 5th Guards Tank Army was now in reserve, but it was still located by FHO as part of the front reserve for the 2nd Ukrainian Front.66 The XVI Tank Corps of the 2nd Tank Army was believed to have reverted from the front reserve to actual deployment on the 2nd Ukrainian Front. The III Tank Corps of the 2nd Tank Army was noted to have reverted from the front reserve to deployment on the 2nd Ukrainian Front on June 17, 1944.67 FHO. concluded that the 2nd Tank Army was deployed on the 2nd Ukrainian Front (see Figure 9) when it had actually been redeployed to the 1st Belorussian Front. The 5th Guards Tank Army was still noted to be in the 2nd Ukrainian Front reserve as of June 17, 1944 (see Figure 9).68 However, it had actually shifted to the 3rd Belorussian Front. Therefore, FHO conclusions as to the area of the next major Soviet offensive continued to be directed toward the south. The tank armies were to be the chief components of the expected offensive against Army Group North Ukraine while the attacks against Army Group Center and South Ukraine were diversionary. The consequences of this intelligence failure were catastrophic and resulted in the destruction of Army Group Center. 
Figure 10 delineates German projected deployment of Soviet Armies alongside the actual Soviet deployment. The figure can be interpreted by use of the following legend:

1-- Position of the sides by the start of the

Belorussian operation; 2 -- Deployment of ob' yedineniya of Soviet forces on the situation map of the German General Staff of the land forces on 22 June 1944; 3--Actual deployment of Soviet forces on 22 June 1944; Troop lift carried out by Hitler's command for closing gaps in the penetrated front in Belorussia; 5 --Sebastopol; 6 -- Baltic Front; 7--Belorussian Front; 8 .. Ukrainian Front; 9 .. Army Group South Ukraine; 10 - Army Group North Ukraine; 11 .- Army Group North; 12 -- Army Group Center; 13 -- Kiev; 14 .- Dnepr; 15 -Black Sea. 69

The German overall estimate of Soviet Amies in Belorussia fell short. Specifically, the Russians had $25 \%$ more units opposite Army Group Center than German Intelligence had identified (see Table 1).

\section{ARMY GROUP CENTER'S PROJECTION OF THE SOVIET SUMMER OFFENSIVE}

Army Group Center had remained in agreement with OKH and the FHO assessment of the location of the major summer offensive until the middle of June 1944. Even as of June 2, 1944, Army Group Center's analysis did not contradict $\mathrm{OKH}$ and $\mathrm{FHO}$ as revealed by the situation assessment:

Repercussions are to be expected from the imminent Soviet offensive against Army Group North Ukraine, on 
German 2nd Army's extreme right (VIII corps). No preparations for an offensive aimed at Brest have been detected, but local attacks are possible. On the Eastern Front, holding attacks on friendly forces must be reckoned with, especially in these sectors: Southeast of Vitebsk, Lenino-Bayevo (northeast of Gorki), Northwest of Chausy, Southwest of Chausy, North of Rogachev, South of Zhlobin. The enemy will endeavor to exploit any inital successes with great speed by concentrating his reserves. On Army Group Center's extreme right the effects of some kind of offensive directed onto Polotsk may be felt. 70

However, the situation before Army Group Center had changed by June 14,1944 . More Soviet reinforcements were were noted to have deployed before Army Group Center which caused General Krebs, Chief of Staff Army Group Center, to raise this issue with General Zeitzler at the $\mathrm{OKH}$ conference concerning Soviet offensive plans. Zeitzler and Gehlen only recognized these troop concentrations as preparations for diversionary or feint attacks while the main offensive would occur against Army Group North Ukraine.

General Peter Von der Groeben, an operations officer, at Army Group Center stated:

After May 1944...a systematic concentration to front of the arc-shaped line held by Army Group Center was evident. Aerial reconnaisance, agents' reports and especially radio intelligence furnished Army Group Center with a clear and pertinent picture of the assembly of Russian forces. ${ }^{71}$

Groeben claimed that there was no doubt on the part of Army Group Center's High Command that the attack would fall on Army Group Center because of the tremendous concentrations that the Soviets 
had deployed opposite the front. ${ }^{72}$ Field Marshal Busch had made it repeatedly clear in reports and in personnal discussions at the Fuehrer's Headquarters the grave situation of the Army Group. ${ }^{73} \mathrm{He}$ requested adequate reserves, mobile units and heavy weapons. However, despite all requests no reserves were released to Army Group Center until June 16th when the 20th Panzer Division was transferred from Army Group North Ukraine to the 9th Army in Army Group Center.

The Army Group continued to observe hopelessly the indications of a major, impending offensive. On June 18, 1944, signal intelligence indicated the possible appearance of the 5th Guards Tank Army but FHO and OKH rejected this evidence even though Marshal Rotmistrov, Commander of the 5th Guards Tank Army, had supposedly been seen near Yartsevo (northeast of Smolensk). The Army Group intelligence summary prepared by Oberst Worgitzky on June 19, 1944 took a much different view than $\mathrm{FHO}$ and $\mathrm{OKH}$ :

The enemy situation has changed considerably since the 2nd of June. Up till then the local attacks were going on, accomplished by regrouping and concentration of available forces, suggested that the enemy had an operational-level holding attack in mind. Now activity opposite the Army Group's salient, notably in the Gomel area and east of Orsha, indicates that his intentions are rather more far-reaching...In sum it must be said that the enemy attacks to be expected on Army Group Center's sector--on Bobruisk, Mogilev, Orsha, and possibly northeast of Vitebsk will be of more than local character. All in all the scale of ground and air forces suggests that the aim is to bring about the collapse of 
Army Group Center's salient by penetrations on several sectors... ${ }^{74}$

The intelligence summary of June 19, 1944 remained largely unchanged till the beginning of the offensive. The railway sabotage on the night of June 19-20th was regarded as an indicator that "the opening of the offensive must be regarded as imminent."75

The commander of the Ninth Army, General Hans Jordan, summed up the feeling of the Army Group in his Kriegstagebuch entry of June 22, 1944:

Ninth Army stands on the eve of another great battle, unpredictable in extent and duration. One thing is certain: in the last few weeks the enemy has completed an assembly on the very greatest scale opposite the army, and the army is convinced that that assembly overshadows the concentration of forces off the north flank of Army Group North Ukraine...The army has felt bound to point out repeatedly that it considers the massing of strength on its front to constitute the preparation for this year's main Soviet offensive, which will have as its object the reconquest of Belorussia.

The army believes that even under the present conditions, it would be possible to stop the enemy offensive, but not under the present directives which require an absolutely rigid defense...there can be no doubt...if a Soviet offensive breaks out the army will either have to go over to a mobile defense or see its front smashed...

The army considers the orders establishing the "fortified places" particularly dangerous.

The army, therefore, looks ahead to the coming battle with bitterness, knowing that it is bound by orders to tactical measures which it cannot in good conscience accept as correct and which in our own earlier 
victorious campaigns were the causes of the enemy defeats--one recalls the great breakthrough and encirclement battles in Poland and France.

The Commanding General and Chief of Staff presented these thoughts to the army group in numerous conferences, but there, apparently, the courage was lacking to carry them higher up, for no counterarguments other than references to $\mathrm{OKH}$ orders were given. And that is the fundamental source of the anxiety with which the army views the future. 76

\section{SOVIET SECRECY AND ALLIED DECEPTIONS \\ IN THE SUMMER OF 1944}

According to General John Deane, the military attache in Moscow a plan was developed for the summer of 1944 that would be mutually beneficial to the Soviets and the western allies. The plan was codenamed "Bodyguard" and involved Soviet feints against Scandinavia and Rumania to deceive the Germans into thinking some coordinated allied operations were to take place on the Axis flanks to draw off German units from northern France. 77 The Joint Chiefs of Staff of the United States were particulary concerned that the Red Army launch its summer offensive to facilitate the "Overlord" operation.

The Joint Chiefs agreed on March 27, 1944 to inform the Soviet General Staff of the target date for Operation Overlord.78 General Deane's memorandum to the Joint Chiefs of February 27, 1944 made it very clear that the Soviets would require a date for Overlord in order to plan their offensive, and that the Soviet front 
was too fluid for them to inform the allies as to where their main effort would be.79 Deane's memorandum was submitted to the Combined Chiefs of Staff.

On April 3, 1944, the Combined Chiefs of Staff sent a telegram to the U.S. and British Military Missions in Moscow giving the date for Overlord as "May 31st with two or three days margin on either side to allow for weather and tide." 80 The British Chiefs of Staff were particulary concerned that the Russians fulfill the obligation Marshal Stalin made at Teheran to launch "a large scale Russian offensive in May with a view to containing the maximum number of German divisions in the East."81 Stalin on April 22, 1944 informed Churchill and Roosevelt that the Soviet General Staff had been informed of the appointed time of the attack and the strength of it by Generals Deane and Burrows. Stalin then made a pledge to fulfill his commitments made at Tehran:

As agreed in Tehran, the Red Army will launch a new offensive at the same time so as to give maximum support to the Anglo-American operations. 82

Nevertheless, the Soviets violated this pledge by beginning a secondary offensive against Finland four days after the Normandy landings. The Soviets failed to launch their offensive at the same time and then the offensive launched against Finland was not the main offensive thereby denying the maximum support promised to the allied landings.

The Soviet plans continued to remain a secret from even their western allies. Despite the British request for for an offensive in 
May prior to Overlord a lull settled over the Eastern Front except in the Crimea. On May 25, 1944, the western allies were still ignorant of Soviet plans while the Soviets were fully aware of the date of the Overlord operation. Thus, Soviet secrecy and deception were not only working against the Germans but also their own allies. The London Joint Intelligence Committee report of May 25, 1944 stated:

We believe that they (Russians) will launch a general offensive concurrently with Overlord. There is some evidence that their main effort will be in the sector between the Pripet Marshes and the northern Carpathians. The dispostion of their forces, however, makes it clear that the Russians are capable of launching large-scale offensives in more than one sector and may well do so.83

It is clear that the allies were no better informed as to Russian intentions than Foreign Armies East under Gehlen.

The Soviets were clearly waiting for the launching of Overlord before beginning their next offensive. And it is clear that they were not attempting to tie down German units on the Eastern Front to save allied lives on the beaches of Normandy. Their launching of an offensive against Finland on June 10,1944, four days after the Normandy landings may have corresponded to the "Bodyguard" deception plan, but it was not the main offensive agreed to at Tehran to support the invasion of France. The main offensive was more than two weeks later which allowed the Germans to transfer armored forces to the Western Front. The German High Command transferred the II SS Panzer Korps to the 
Western Front from Army Group North Ukraine beginning on June 12th. Undoubtedly, the lack of pressure along the main front and the remote offensive in Karelia facilitated the transfer of SS

Panzers to the bocage of Normandy.

Finally, the day after the Normandy landings Stalin sent Roosevelt and Churchill a cable providing some information about the expected Soviet summer offensive:

The summer offensive of the Soviet troops to be launched in keeping with the agreement reached at the Tehran Conference will begin in mid-June in one of the vital sectors of the front. The general offensive will develop by stages, through consecutive engagement of the armies in offensive operations. Between late June and the end of July the operations will turn into a general offensive of the Soviet troops.

I shall not fail to keep you posted about the course of the operations. 84

Stalin on June 9, 1944 informed Churchill that:

Preparations for the summer offensive of the Soviet troops are nearing completion. Tomorrow, June 10, we begin the first round on the Leningrad Front. 85

However, the Belorussian Operation remained a secret to the end. On June 21, 1944, Stalin informed Churchill and Roosevelt that the second round of the Soviet summer offensive would commence within a week and would "involve 130 divisions including armored ones." 86 Thus, Stalin never did reveal the location and exact timing of the Soviet main offensive to his western allies. Soviet secrecy concerning the Belorussian Operation remained extremely well guarded. 
Meanwhile, allied disinformation was filtering through German diplomatic channels concerning the Soviet summer offensive. OKW received a report through the Auswartiges Amt (Foreign Office) in Ankara, Turkey concerning a conversation between the Finnish envoy and the U.S. Ambassador Steinhardt. Steinhardt apparently told the Finnish envoy on June 6, 1944 that the Soviet offensive would begin in about 14 days on the Rumanian Front where 8000 tanks were assembled. This information was confirmed by Hiesinger, a member of the Soviet embassy. 87 It is interesting to note that the date of the offensive was approximately correct, but the location was totally inaccurate.

A telegram from the German Ankara Embassy on June 9, 1944 conveyed a conversation that U.S. Ambassador Steinhardt had with a friendly neutral diplomatic Mission Chief. Steinhardt was reported to have stated that the Soviet offensive "would begin on June 15th with a strong group against the Carpathians, a medium strength group in the area of Jassy and a very strong group against the Rumanian Front."88 It is unclear where Steinhardt was obtaining his information but one aspect of the Bodyguard Deception plans was to make the Germans believe that the attacks would occur on the flanks. 


\section{SOVIET MILITARY DECEPTIONS}

The Soviet deception plan to deceive the Germans can be divided into five elements:

(1) extremely tight security; (2) maintenance of the German preconception that the Ukraine was the Schwerpunkt of the main Soviet offensive; (3) Elaborate measures to conceal offensive preparations on the Belorussian Front; (4) masking redeployments by simulating normalcy along the entire front; (5) a major feint against Finland preceeded the main offensive which was staggered by fronts to confuse the Germans.

The tight. security of the Soviets can be traced to the limited distribution of the Soviet offensive plans in their entirety. Only six people were aware of the Soviet summer plans. These individuals were: Stalin, the Supreme Commander-in-Chief, the Deputy Supreme Commander-in-Chief, the Chief of the General Staff, and the Chief of the Operations Division and his deputy. 89 The plans were issued in single hand delivered copies for each front. Therefore, the majority of personnel had only a partial knowledge of the overall plan.

The Soviets continued to simulate preparations for an offensive from the Ukraine. The Commander of the 3rd Ukrainian Front was ordered to simulate a false concentration of troops to the northeast of Kishinev.90 Tolbukhin was specifically ordered to simulate the arrival of nine divisions and one armored corps. The simulation was conducted by rail through four main depots between May 29th and June 14th..$^{91}$ Similar use of rail deception was 
conducted elsewhere in the Ukraine. Massive rail activity was observed opposite Brest along the southern flank of Army Group Center during the spring. The greater part of the transport trains that were reported by aerial observation were empty and only served as a deception which was discovered only much later.92 Dummy tanks, artillery, aircraft, depots and radio nets were established to deceive the Germans. Stalin admitted that the Russians constructed as many as 5000 false tanks and 2000 false aircraft to mislead German intelligence in the past.93 The Soviets even developed a real antiaircraft zone with complete fighter cover. Long range aircraft used for attacks against German airfields and railroad junctions were based in the Ukraine to disorient the Germans. ${ }^{94}$ However, these aircraft flew combat missions against both Army Group North Ukraine and Army Group Center.

Elaborate procedures were established to conceal the Belorussian offensive. In April 1944, STAVKA ordered a shift to a defensive posture along the front. According to Marshal Ivan Bagramian, Commander of the First Baltic Front, STAVKA ordered the creation of a defensive zone of not less than 25 miles with three defensive lines. ${ }^{95}$ The evacuation of all civilian population from this zone adjoining the front was carried out to prevent the Germans from infiltrating agents into the area where they could easily conceal themselves among the local population.96 Therefore, thousands of families were evacuated from the 25 mile zone to nearby districts. 
Careful procedures were utilized in the area along the Belorussian sector to conceal the offensive preparations. Trains were unloaded at night and trains were dispatched to unloading points of up to $100 \mathrm{~km}$ from the front line. During the day special camouflage nets, canvas and bales of hay were used to conceal the buildup of supplies.97 All military units were instructed to camouflage themselves during the day and the Soviets checked their concealment by flying aerial reconnaissance over their own positions to insure effective compliance.98 Commanders were ordered to wear infantry uniforms only when conducting all reconnaissance of the front line. Radio silence was instituted along the front in May and only the air force, air defense, reconnaissance and artillery fire direction nets were allowed to remain active. All troop movements and unit relocations were conducted at night. Even artillery units were ordered to maintain their pattern of fire. Tractors were assigned to follow tank and artillery units to cover their tracks by dragging tree branches to erase evidence of their presence. These concealment measures proved fairly effective and the Germans only began taking notice of the Soviet buildup after the first week in June.

The Soviets also simulated normalcy along the front. Reconnaissance was conducted along the entire front by company and battalion size units. This masked the intentions of future Soviet operations. Probes in one sector would be matched by probes in another sector so as to simulate normalcy along the entire front. 
Finally, the feint against Finland distracted German attention away from the ongoing Belorussian offensive preparations. The Soviet planning of the offensive called for the offensive to be conducted in stages. The feint against Finland combined with a staggered offensive confused the Germans until the offensive developed into a clear general offensive. The 1st Baltic Front lead off the attack on June 22-23rd, followed by the 3rd Belorussian Front which then extended to the 2nd and 1st Belorussian Fronts. The offensive was staggered by approximately 48 hours from north to south possibly because the required air power could not be brought to bear at all the critical points simultaneously. This created the impression of holding attacks which confused the German High Command until the full weight of the offensive was joined on June $25,1944.99$ 


\section{TABLE I}

DEPLOYMENT OF SOVIET ARMIES ON TWO FRONTS, 22 JUNE 1944

\section{BELORUSSIAN}

German Actual

Estimate Deployment

Tank Armies: 0

Other Armies:

TOTALS:

Source: Barton Whaley, Strategm: Deception and Surprise in War, (1969), p. A-393.

\section{UKRAINE}

German Actual

Estimate Deployment

$6 \quad 4$

? ?
$?$ ? 


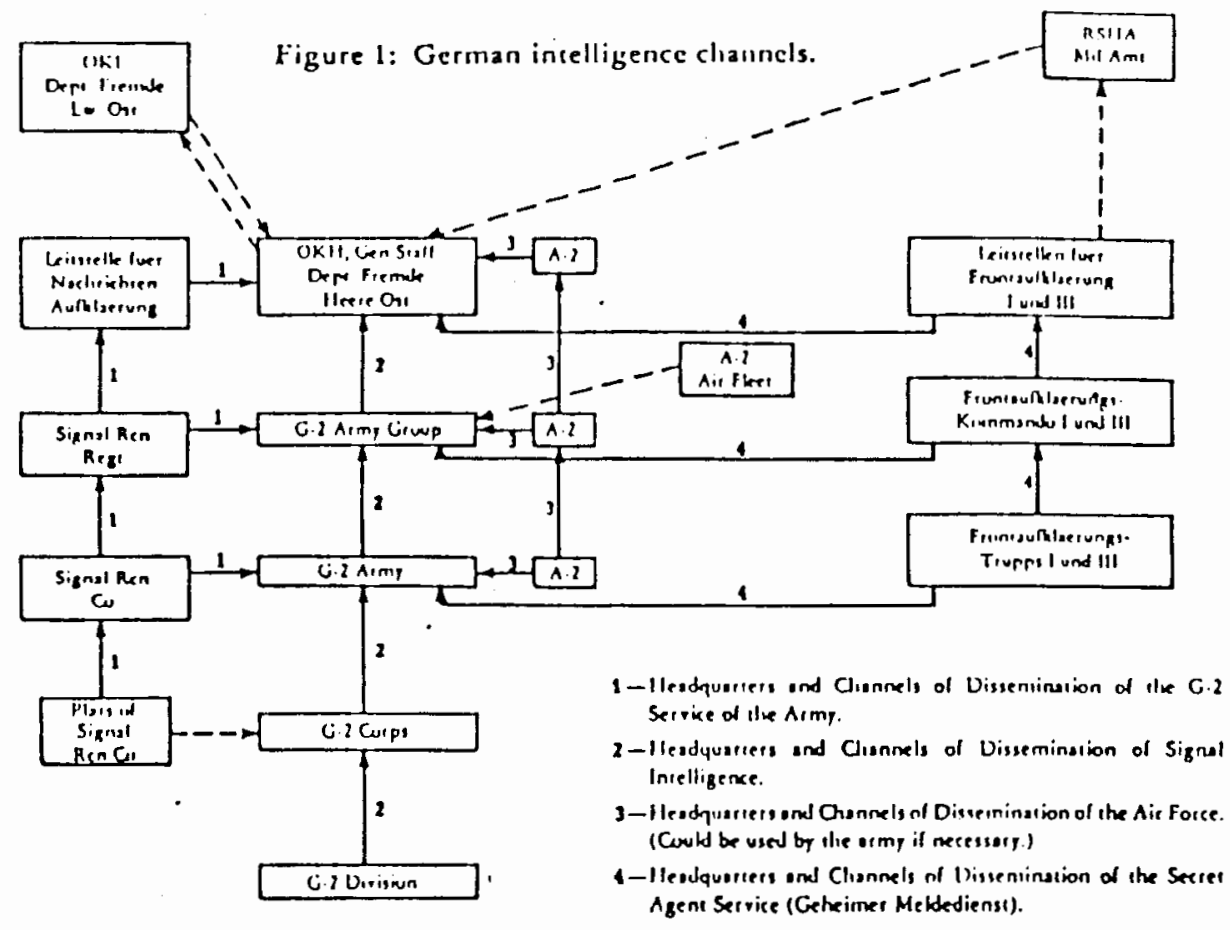

Figure 1. German Intelligence Channels. Source: U.S. War Department, Military Intelligence Division, German Military Intelligence 1939-1945 (Frederick, Maryland: University Publications of America, Inc., 1984), p. 12. 
Vermuticher Ansatz u. Rictitung der gegenwärtigen unocti zus er. wartenden sowj russ. Angriffs: operationen

Stand: 29.3 .44

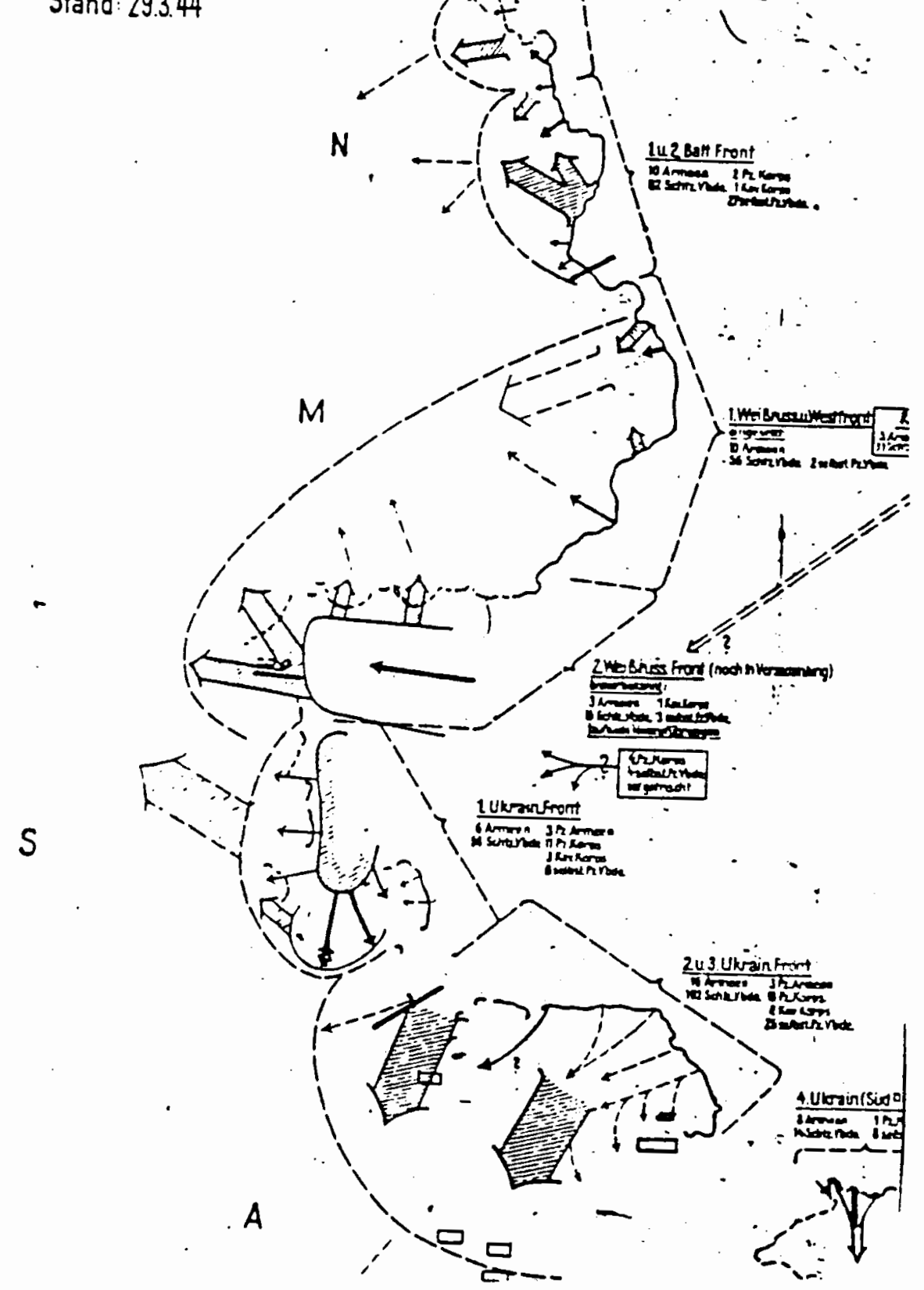

Figure 2. Probable Disposition and Direction of the Present and Remaining Anticipated Soviet Offensive Operations, March 29, 1944. Source: National Archives Microfilm Publication T-78, Roll 587. 


\section{Vermutliche sowj.rușs. Operationsrichtungen} und derzeitiger feindl.Kräfteeinsatz

\section{Stand: 3.5 .44 früh}

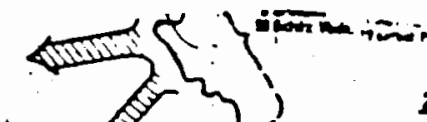

2

M

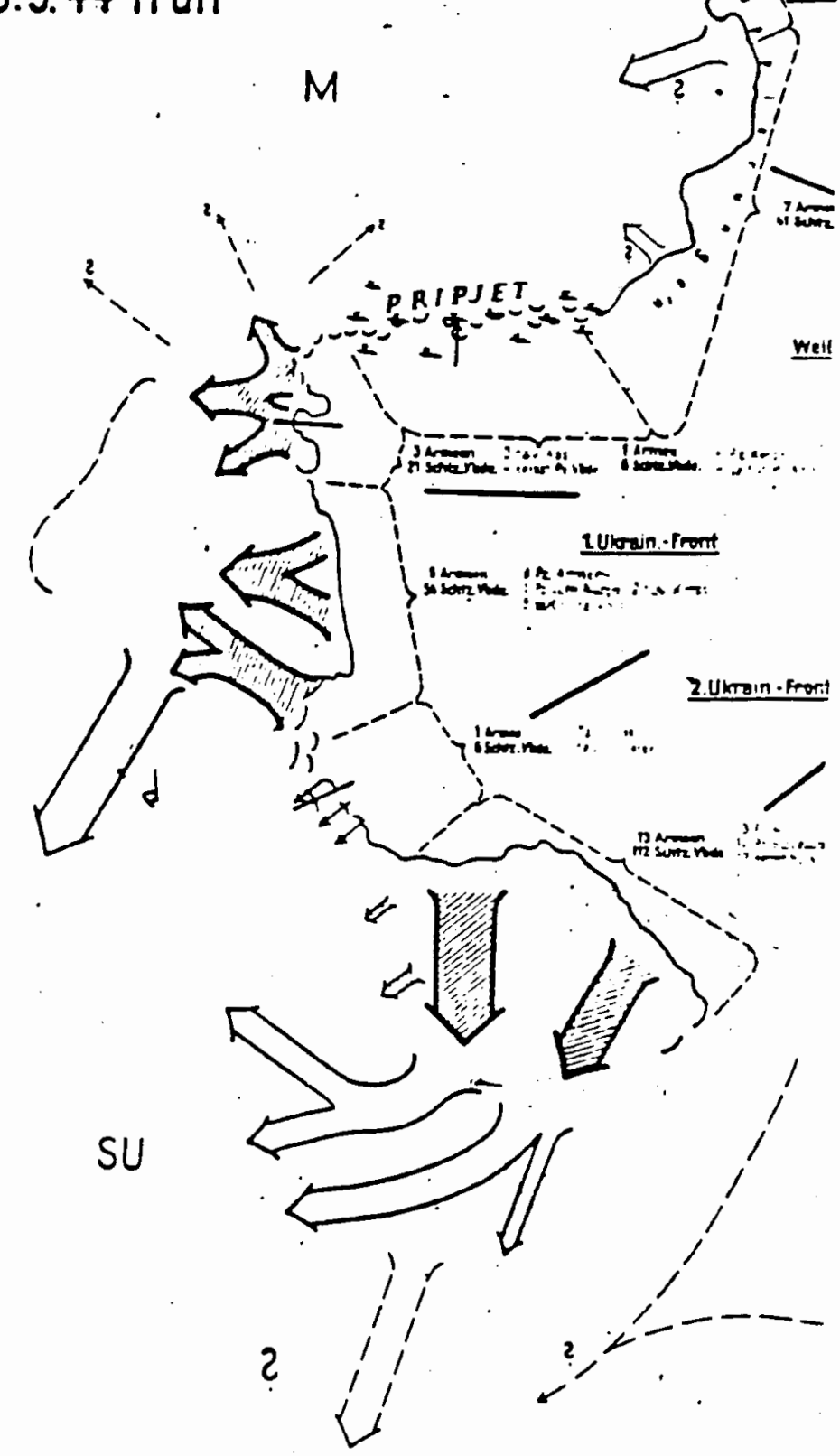

NU

Figure 3. Probable Soviet Operational Directions and Current Enemy Force Deployment, May 3, 1944. Source: National Archives Microfilm Publication T.78, Roll 587. 


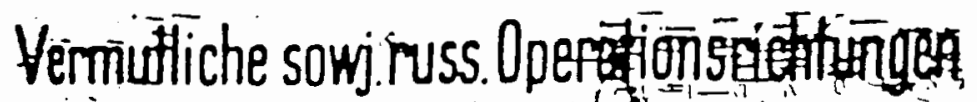

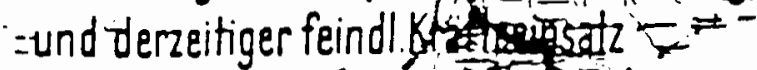

$\therefore$ Stand: $\not 5$ S

a $=0$

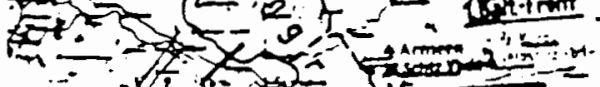

$=-12$ on

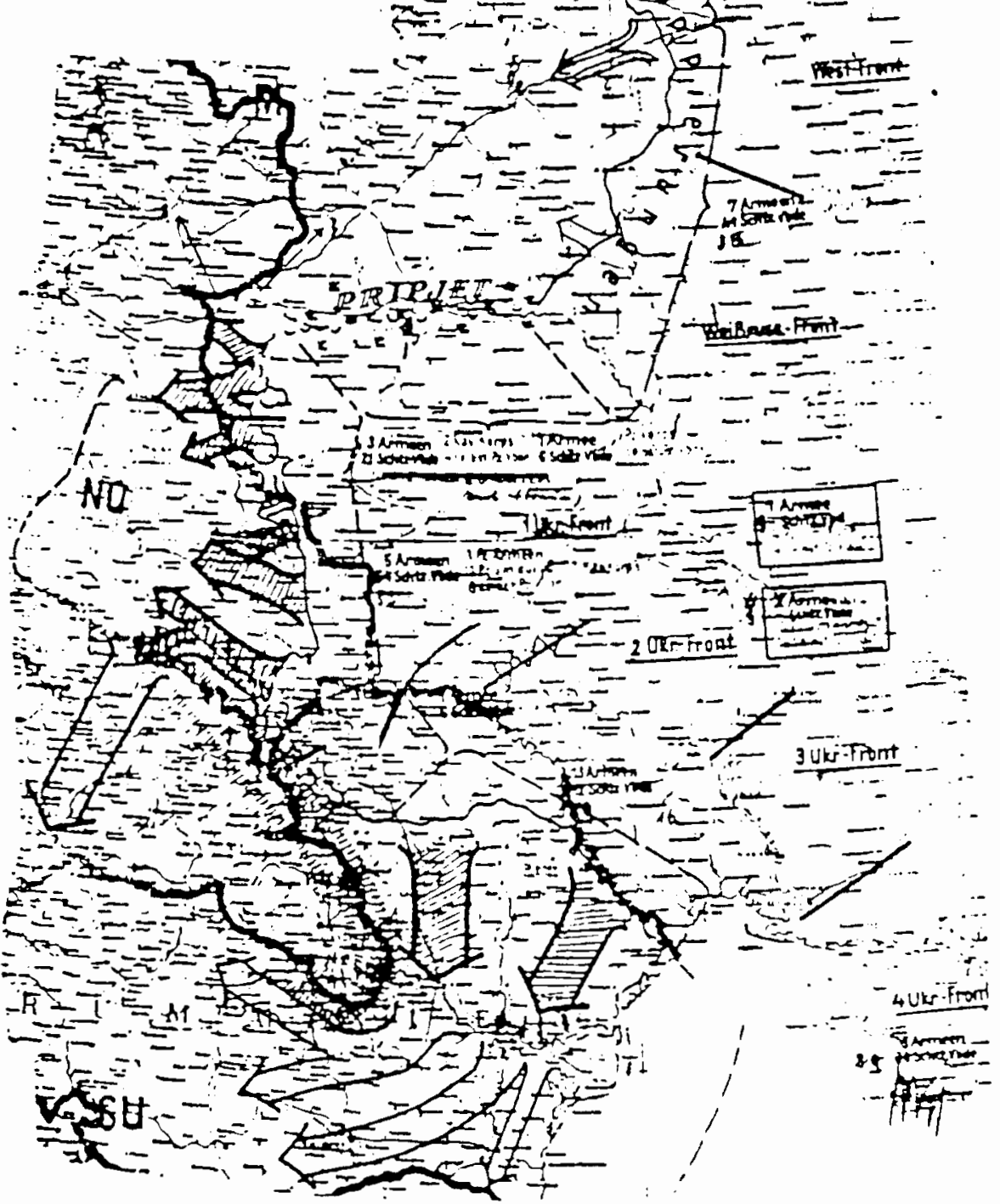

Figure 4. Probable Soviet Operational Directions and Current Enemy Force Deployment, May 3, 1944. Source: National Archives Microfilm Publication T-78, Roll 581. 


\section{Vermutliche sowj.russ.}

Operationsabsichten $-1 y$

und derzeitiger feindl. Krafteeinsătz y

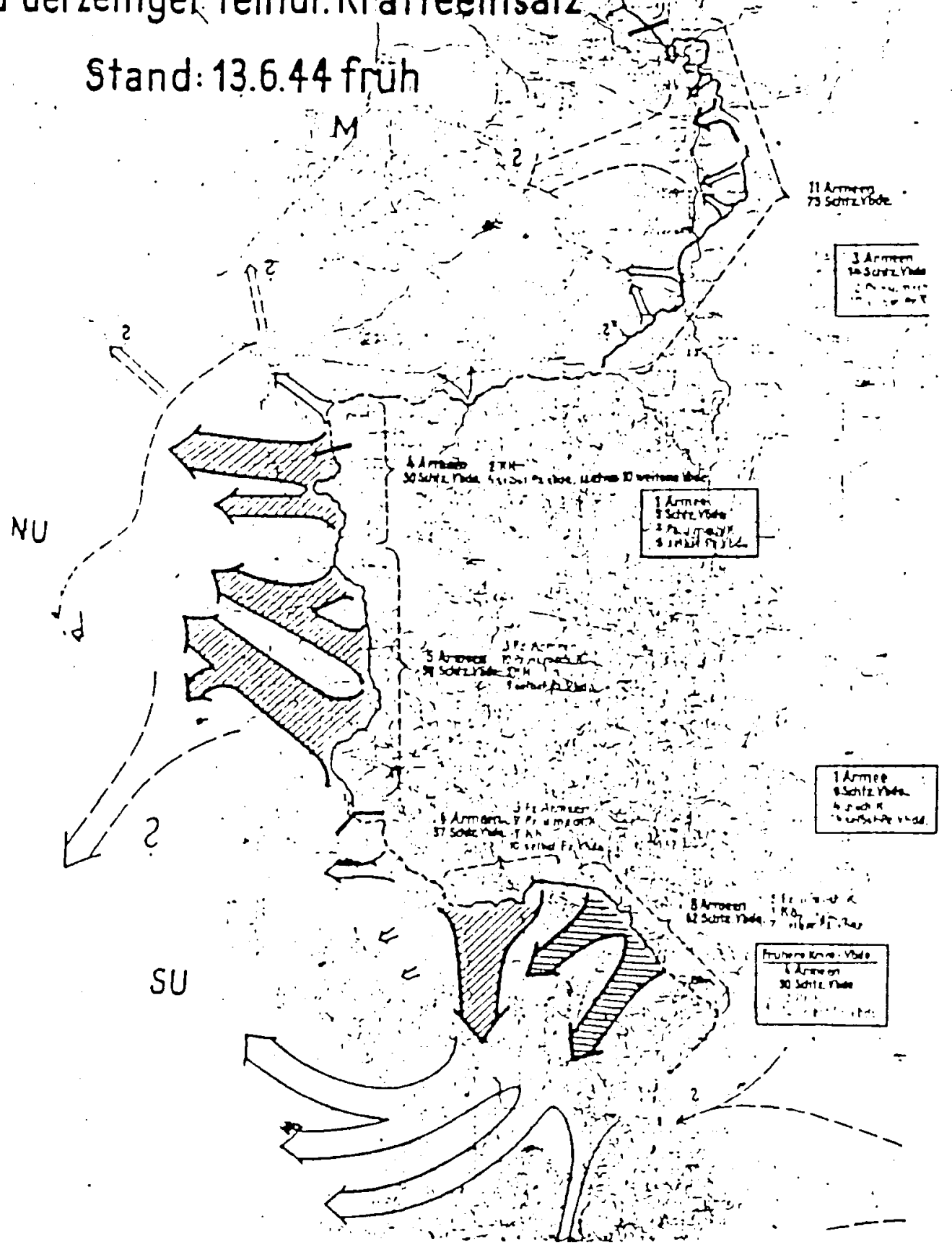

Figure 5. Probable Soviet Operational Intentions and Current Enemy Force Deployment, June 13, 1944. Source: National Archives Microfilm Publication T-78, Roll 587. 


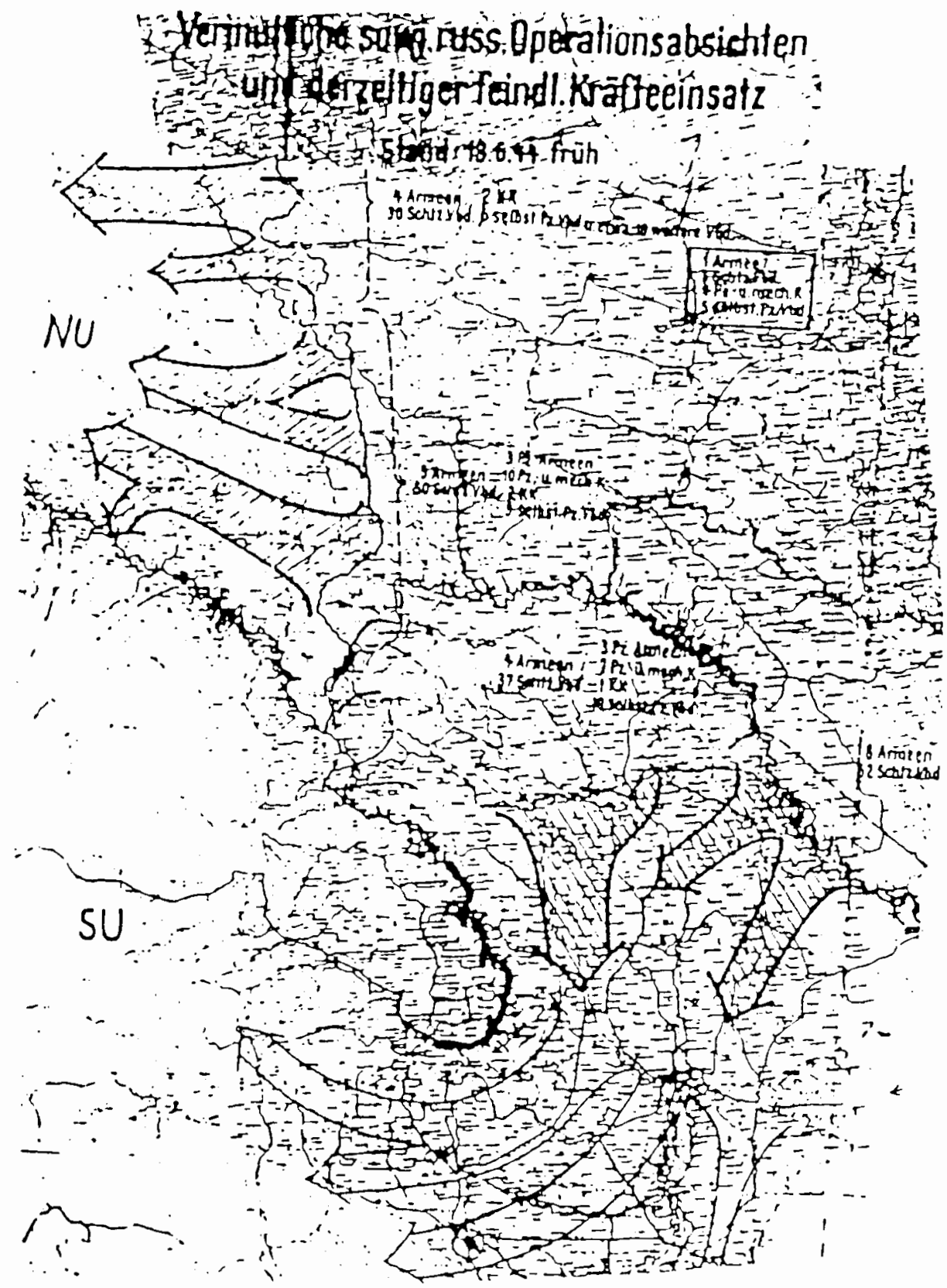

Figure 6. Probable Soviet Operational Intentions and Current Enemy Force Depioyment, June 13, 1944. Source: National Archives Microfilm Publication T-78, Roll 587. 


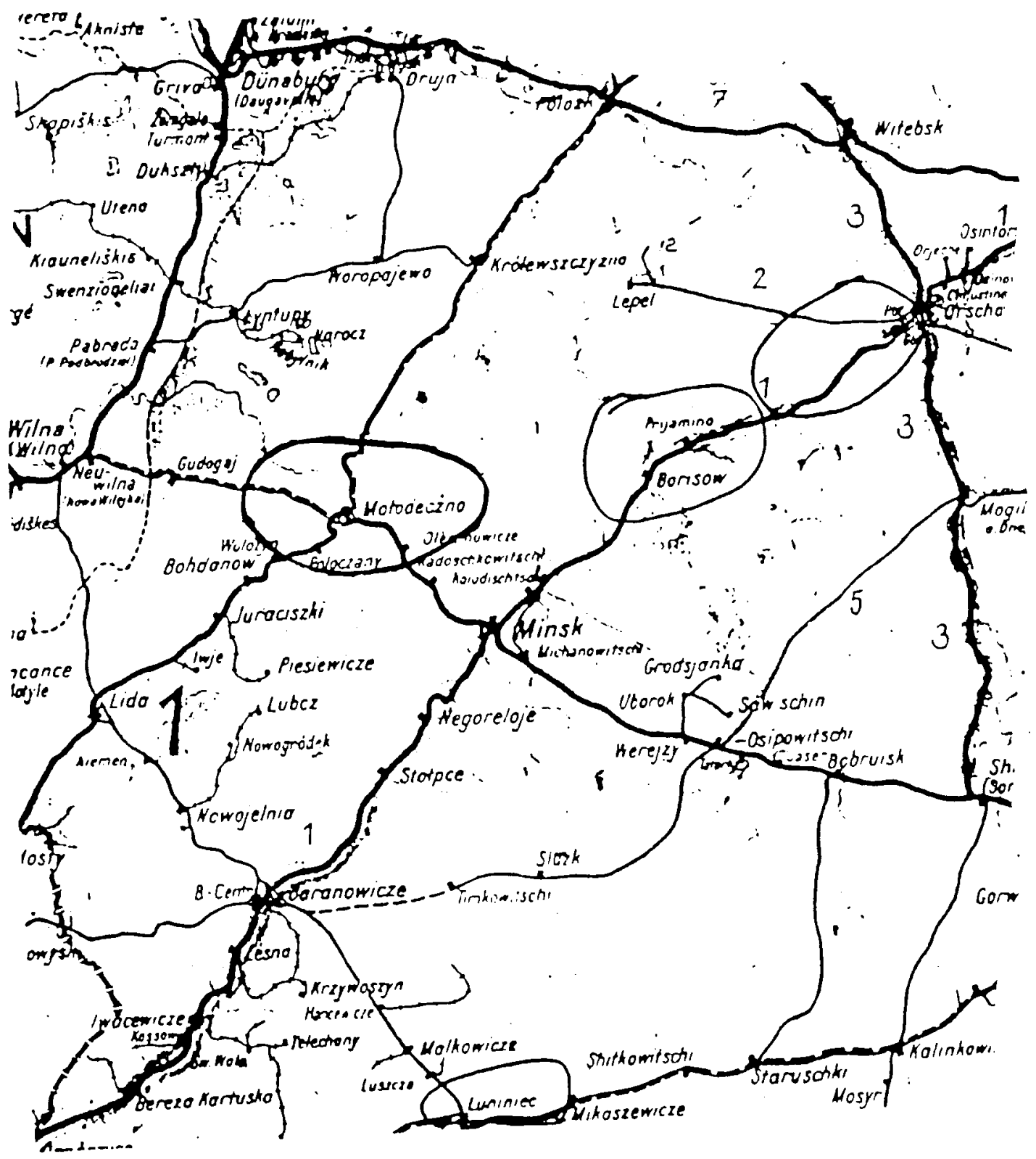

Figure 7. Belorussian Partisan Rail Attacks, June 1920, 1944. Source: National Archives Microfilm Publication T-78, Roll 113. 


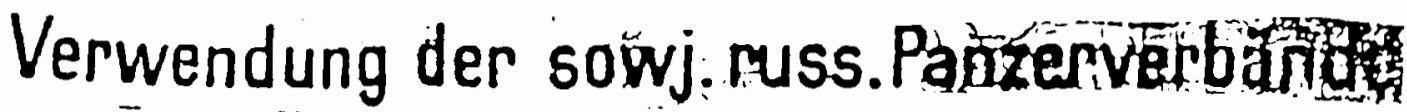 Dor deutscher Osffint}

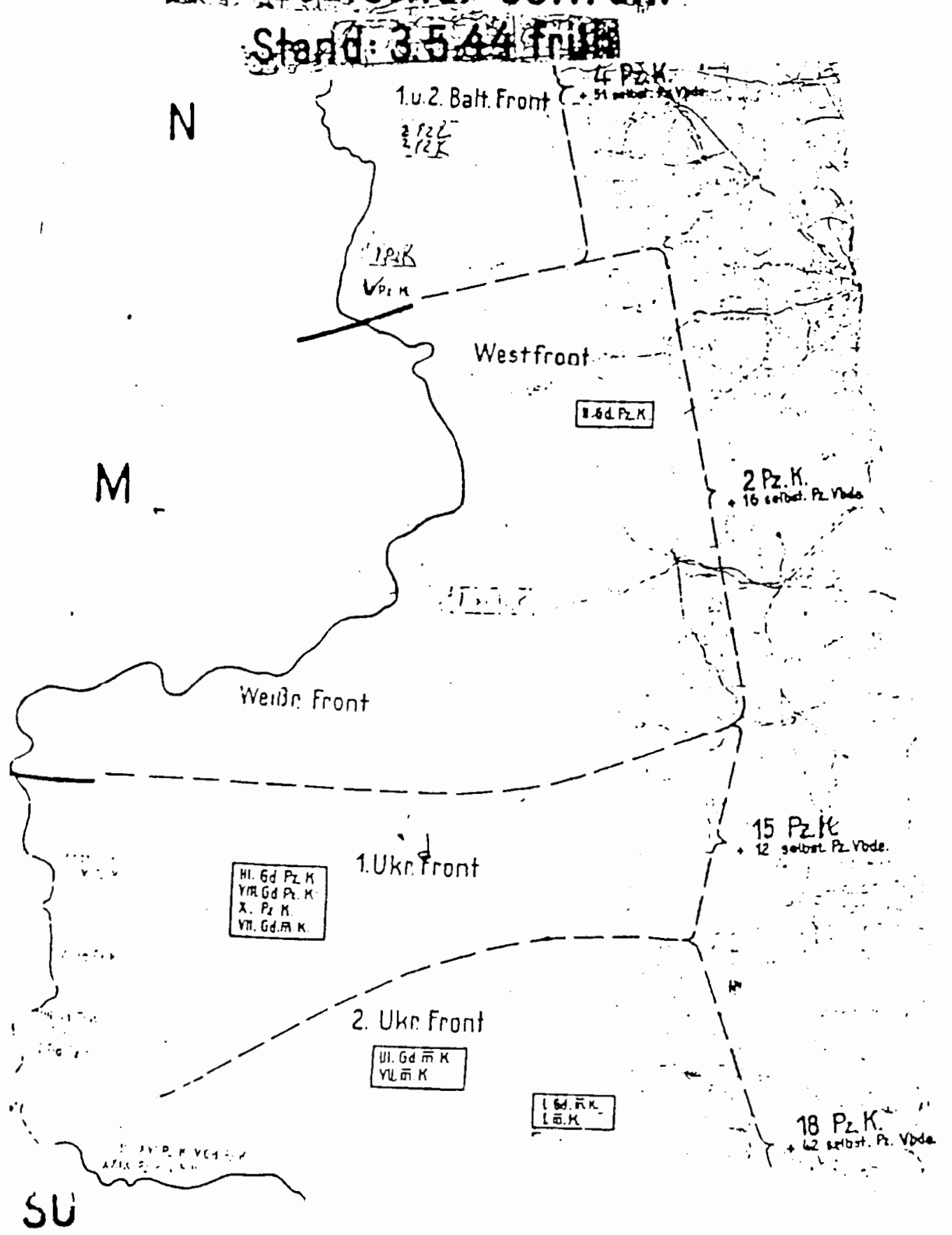

Figure 8. Employment of Soviet Tank Formations Opposite the German Eastern Front, May 3, 1944. Source: National Archives Microfilm Publication T-78, Roll 587. 

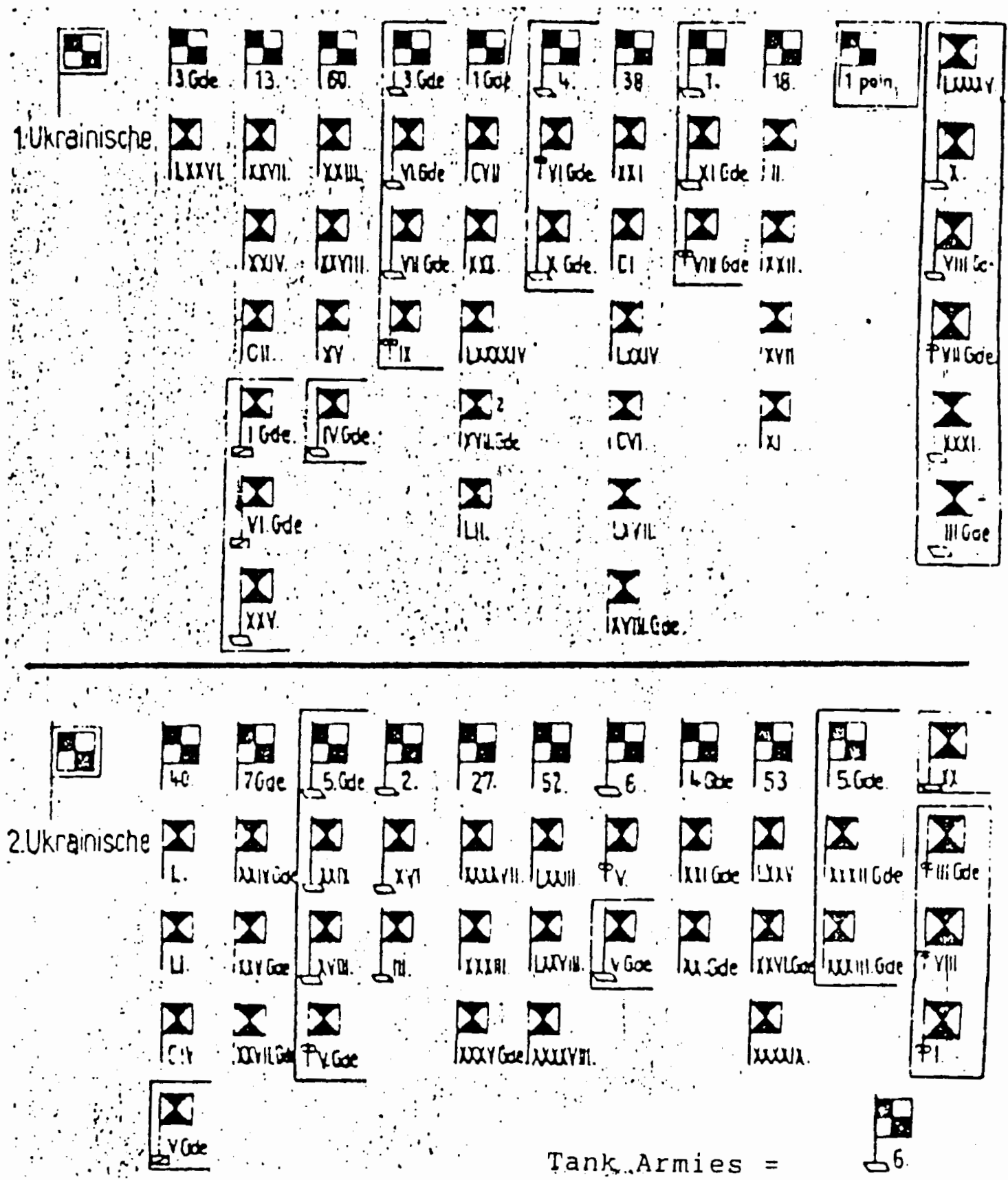

Figure 9. The Six Tank Armies of the Red Army, Order of Battle on June 17, 1944 as Noted by Fremde Heer Ost.

Source: Kommandobehoerden der Roten Armee. Gliederung 17.6.1944, National Archives Microfilm Publication T-78, Roll 588. 


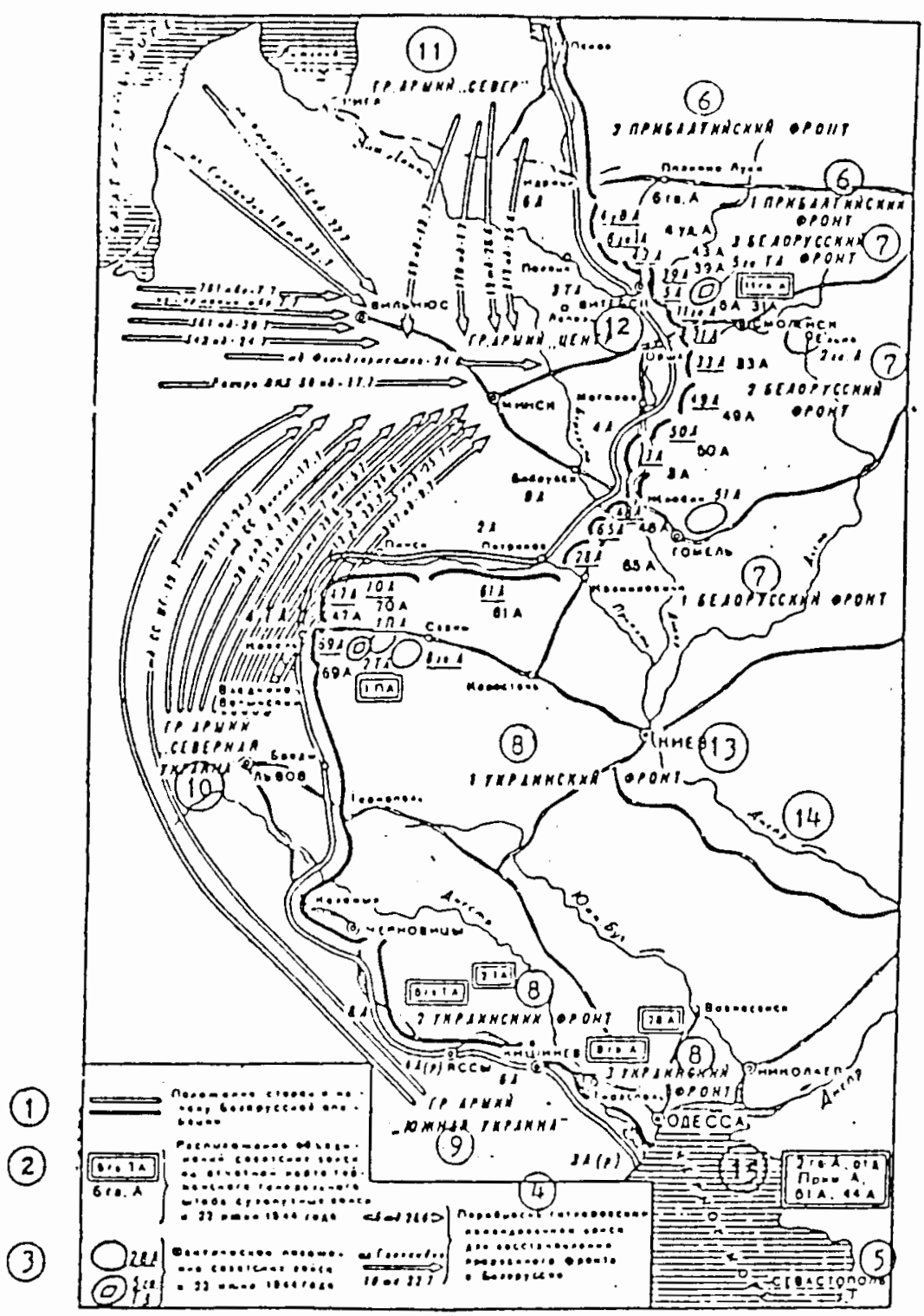

Figure 10. Deployment of Soviet Forces by the Start of the Belorussian Operation. Source: Colonel A. Shimanskiy, "1944 Summer-Fall Campaign On The Eastern Front," Joint Publications Research Service No. 46237 (20 August 1968), p. 6. 


\section{NOTES TO CHAPTER ॥}

1972), p. 41.

${ }^{1}$ General Reinhard Gehlen, The Service (New York: World Publishing Company,

2David Kahn, "An Intelligence Case History: The Defense of Osuga," Aerospace Historian Vol. 28 No. 4 (1981): 242-252.

3Gehlen, The Service, p. 96.

${ }^{4}$ Hans-Heinrich Wilhelm and Louis De Jong, Zwei Legenden Aus Dem Dritten Reich (Stuttgart: Deutsche Verlags-Anstalt GMBH, 1974), p. 59.

${ }^{5}$ Zusammenfassende Beurteilung der Feindlage vor deutscher Ostfront und Vermutete Feindabsichten im Grossen, 30.3.1944, National Archives Microfilm Publication T-78 Roll 497; Wichtige Abwehmeldungen der Letzen Zeit Ueber Sowjetrussische Operationsabsichten, 30.3.1944, National Archives Microfilm Publication T-78, Roll 581.

${ }^{6}$ Wilhelm and De Jong, p. 59.

7 Ibid.

8Ziemke, Stalingrad to Berlin: The German Defeat In The East (New York: Dorset Press, 1968), p. 313; Zusammenfassende Beurteilung der Feindlage vor deutscher Ostfront und Vermutete Feindabsichten im Grossen, 3.5.44, National Archives Microfilm Publication T-78, Roll 581.

9lbid.

10 Wilhelm and De Jong, p. 60.

${ }^{11}$ Entwicklung und Beurteilung der Feindlage im Raum Luzk-Kowel-Sarny fuer die Zeit vom 15.2.-10.5.44. National Archives Microfilm Publication T-78, Roll 582.

${ }^{12}$ Colonel A. Shimanskiy, "1944 Summer-Fall Campaign On The Eastern Front," Joint Publications Research Service No. 46237 (20 August 1968), p. 11.

${ }^{13}$ Ziemke, Stalingrad to Berlin: The German Defeat In The East, p. 313.

${ }^{14}$ Kurt Mehner, Die Geheimen Tagesberichte Der Deutschen Wehrmachtfuehrung Im Zweiten Weltkrieg 1939-1945 Vol. 10 (Osnabrueck: Biblio Veriag, 1985), p. 502. 
15Roger James Bender and Hugh Page Taylor, Uniforms. Organization And History Of The Waffen-SS Vol. 3 (San Jose, California: R. James Bender Publishing. 1972), pp. 48-61.

16 Mehner, p. 502.

17Gerd Niepold, Battle For White Russia: The Destruction Of Army Group Centre June 1944 (London: Brassey's Defense Publishers, 1987), p. 29.

18Ziemke, Stalingrad to Berlin: The German Defeat in The East , p. 314.

19 Mehner, p. 500.

${ }^{20}$ Shimanskiy, p. 4.

21Ziemke, Stalingrad to Berlin: The German Defeat In The East, p. 315.

22Shimanskiy, p. 4.

23 ibid., p. 8.

24 ibid.

25Ziemke, Stalingrad to Berlin: The German Defeat In The East, p. 315.

${ }^{26}$ Herman Gackenholz, "The Collapse of Army Group Centre in 1944," Decisive Battles of World War Il: The German View ed. H.A. Jacobsen and J. Rohwer (New York: G.P. Putnam's Sons, 1965), p. 362.

27 Niepold, Battle for White Russia: The Destruction of Army Group Centre June 1944, pp. 17-18.

${ }^{28}$ Grossabotage Auftrag fuer "Grischin", 12 June 1944, National Archives Microfilm Publication T-77, Roll 856.

${ }^{29}$ Alexander Werth, Russia At War 1941-1945 (New York: Caroll \& Graf Publishers, Inc., 1964), p. 717.

${ }^{30}$ Kurt Von Tippelskirch, Geschichte Des Zweiten Weltkriegs (Bonn: Athenaeum-Verlag, 1956), p. 460.

31 Wilhelm and De Jong, p. 60.

32Ibid.

33Gehlen, The Service, p. 96. 
34Ibid., pp. 96-97; Zusammenfassende Beurteilung der Feindlage vor deutscher Osttront und Vermutete Feindabsichten im Grossen, 13.6.1944, National Archives Microfilm Publication T-78, Roll 581.

35Ibid.

${ }^{36}$ Gehlen, The Service, p. 97.

37 Shimanskiy, p. 11; Zusammenfassende Beurteilung der Feindlage vor deutscher Ostfront und Vermutete Feindabsichten im Grossen, 13.6.1944, National Archives Microfilm Publication T-78, Roll 581.

38 ibid.

39Hermann Gackenholz, "Zum Zusammenbruch Der Heeresgruppe Mitte Im Sommer 1944" Vierteliahreshefte fuer Zeitgeschichte (July 1955), p. 321.

40Ziemke, Stalingrad to Berlin: The German Defeat In The East, p. 315.

${ }^{41}$ Gackenholz, "The Collapse of Army Group Centre in 1944," Decisive Battles of World War Il: The German View, p. 363.

42Niepold, The Battle of White Russia: The Destruction of Army Group Centre June 1944, p. 17; Zusammenfassende Beurteilung der Feindlage vor deutscher Ostfront und Vermutete Feindabsichten im Grossen. 13.6.1944, National Archives Microfilm Publication T-78, Roll 581; Wichtige Abwehrmeldungen und Gefangen Aussagen ueber Sowj. Russ. Operationsabsichten, 13.6 44, National Archives Microfilm Publication T-78, Roll 581.

${ }^{43}$ Niepold, The Battle of White Russia: The Destruction of Army Group Centre June 1944, p. 18; Zussamenfassende Beurteilung der Feindlage vor deutscher Ostfront und Vermutete Feindabsichten im Grossen, 13.6.1944, National Archives Microfilm Publication T-78, Roll 581.

${ }^{44}$ Rolf Hinze, Der Zusammenbruch der Heeresgruppe Mitte Im Osten 1944 (Stuttgart: Motorbuch Verlag, 1980), p. 29.

${ }^{45}$ Aussage Eines KGF Russen, 19 Juni 1944, National Archives Microfilm Publication T-77, Roll 856.

${ }^{46}$ Shimanskiy, p. 9.

47Gackenholz, "The Collapse of Army Group Centre in 1944," Decisive Battles of World War Il: The German View, p. 364. 
48Hermann Teske, Die Silbemen Spiegel (Heidelburg: Kurt Vowinckel Verlag, 1952), p. 218.

49 bid.

50Niepold, The Battle For White Russia: The Destruction of Army Group Centre June 1944, p. 25.

51 lbid.

52 ibid.

53 Sowjet Aktionen im Mittelabscnitt, 21 Juni 1944, National Archives Microfilm Publication T-77, Roll 856.

${ }^{54}$ Niepold, The Battle For White Russia: The Destruction of Army Group Centre 1944, p. 25.

55Mehner, p. 286.

56/bid., p. 289.

57Ibid., p. 292.

58 Shimanskiy, p. 10.

59Niepold, The Battle For White Russia: The Destruction of Army Group Centre 1944, pp. 24-25.

60 Shimanskiy, p. 10; Uebersicht ueber die Kommandobehoerden der Roten Armee 18.5.1944, 28.5.1944, 7.6.1944, 17.6.1944, National Archives Microfilm Publication T-78, Roll 588.

61 lbid.

62 Uebersicht veber die Kommandobehoerden der Roten Armee 18.5.1944, National Archives Microfilm Publication T-78, Roll 588.

63Uebersicht ueber die Kommandobehoerden der Roten Armee 28.5.1944, National Archives Microfilm Publication T-78, Roll 588.

64 Uebersicht ueber die Kommandobehoerden der Roten Armee 18.5.1944, National Archives Microfilm Publication T-78, Roll 588.

65Uebersicht ueber die Kommandobehoerden der Roten Armee 28.5.1944, National Archives Microfilm Publication T-78, Roll 588. 
66 Uebersicht ueber die Kommandobehoerden der Roten Armee 7.6.1944, National Archives Microfilm Publication T.78, Roll 588.

${ }^{67}$ Uebersicht ueber die Kommandobehoerden der Roten Armee 17.6.1944, National Archives Microfilm Publication T-78, Roll 588.

68 bid.

${ }^{69}$ Shimanskiy, p. 7.

70Niepold, The Battle For White Russia: The Destruction of Amy Group Centre June 1944, pp. 15-16.

${ }^{71}$ Generalmajor Peter Von Der Groeben, "Collapse of Army Group Center and its Combat Activity until Stabilization of the Front," MS\#T-31 World War II German Military Studies Vol. 16 (New York: Garland Publishing, Inc., 1979), p. 8.

72|bid., p. 9.

73!bid., p. 10.

${ }^{74}$ Niepold, The Battle For White Russia: The Destruction of Amy Group Centre June 1944, pp. 23-24; Oberst Worgitzky, Zusammenfassende Beurteilung der Feindlage. 19.6.44, National Archives Microfilm Publication T-311, Roll 234.

75 Niepold, The Battle For White Russia: The Destruction of Army Group Centre June 1944, p. 24.

76Ziemke, Stalingrad to Berlin: The German Defeat In The East, p. 316.

77John Deane, The Strange Alliance (New York: The Viking Press, 1946), p. 148.

78General Deane to the Joint Chiefs of Staff, "Red Army Offensive Action to Faciliate Overlord," 27 March 1944, (Reel 2:0012), Records of the Joim Chiefs of Staff Part 1: 1942-1945. The Soviet Union (University Publications of America, Inc., 1981), p. 7 (hereafter RJCS:USSR).

79 Ibid.

${ }^{80}$ Combined Chiets of Staft to U.S.and British Military Missions in Moscow, "Red Army Action to Faciliate Overiord," 3 April 1944,(Reel 2:0021), RJCS:USSR, p. 7. 
${ }^{82}$ Commision For The Publication Of Diplomatic Documents Under The Ministry Of Foreign Affairs Of The U.S.S.R., Correspondance Between The Chairman Of The U.S.S.R. And The Presidents of The U.S.A. And The Prime Ministers of Great Britain During The Great Patriotic War of 1941-1945 Vol. 1 (Moscow: Foreign Languages Publishing House, 1957), p. 215.

83Joint Intelligence Committee Memorandum for Information Number 74, "Developments on the Eastern Front and their Implications for Overlord," 25 May 1944,(Reel 10:0719), Records of The Joint Chiets of Staff Part 1: 1942-1945. The European Theater (University Publications of America, Inc., 1981), p. 45.

${ }^{84}$ Commision For The Publication Of Diplomatic Documents Under The Ministry Of Foreign Affairs Of The U.S.S.R., Correspondance Between The Chairman Of The Council Of Ministers of The U.S.S.R. And The Presidents Of The U.S.A. And The Prime Ministers Of Great Britain During The Great Patriotic War 1941-1945 Vol. 2 (Moscow: Foreign Languages Publishing House, 1957), p. 145.

85Ibid., Vol. 1, p. 226.

86/bid., pp. 23-231; Ibid., Vol. 2, p. 147.

${ }^{87}$ Ankara Vom 6.6. An Auswartiges Amt, 8 June 1944, National Archives Microfilm Publication T-77, Roll 856.

${ }^{88}$ Telegramm Botschaft Ankara Nr. 924 V. 9.6.44, 8 June 1944, National Archives Microfilm Publication T-77, Roll 856.

${ }^{89}$ Shimanskiy, p. 2.

90P.N. Pospelov et al, History Of The Great Patriotic War Of The Soviet Union 1941-1945 Vol. 4 trans. Foreign Technology Division: Air Force Systems Command, (Moscow: Publishing House "Voyennoye," 1962), p. 242. $393 e$.

${ }^{91}$ Barton Whaley, Strategm: Deception and Surprise in War, (1969) p. A-

92Teske, p. 210.

${ }^{93}$ Deane, The Strange Alliance, p. 146.

94Lt. Colonel Charles G. Fitzgerald, "Operation Bagration," Military Review, May 1964, p. 71.

95Marshal Ivan KH. Bagramian, "The Liberation of Byelorussia (Operation Bagration)," Soviet Generals Recall World War ll ed. Igor Vitukhin (New York: Sphinx Press, Inc., 1981), p. 292. 
96Ibid., p. 293.

97Shimanskiy, p. 5.

98Major Barney F. Slayton, "War in the Ether: Soviet Radio-Electronic Warfare," Military Review Vol. 60, January 1980, p. 62.

99John Erickson, The Road to Berlin (Boulder, Colorado: Westview Press, 1983), pp. 215-220. 


\section{CHAPTER III}

\section{GERMAN DEFENSIVE DOCTRINE IN 1944: \\ STANDING FAST VERSUS ELASTIC DEFENSE}

The German Army defensive doctrine of elastic defense found in the 1933 Truppenfuehrung manual remained in effect as the standard doctrinal reference throughout the war. ${ }^{1}$ However, elastic defense lost its elasticity due to Hitler's orders which confused and muddled German defensive practices. Hitler's inflexibility in how the defense should be conducted resulted in an operational rigidity which produced needless German losses and caused the encirclement amd the destruction of numerous German military formations. In the summer of 1944, elastic defense was the only hope for Army Group Center, but Hitler insisted on a rigid stand fast deployment which resulted in the destruction of twenty-eight divisions. ${ }^{2}$

\section{HITLER'S DOCTRINE OF STANDING FAST}

Hitler's standfast doctrine originated in the winter of 194142. The Wehrmacht had become stalled before Moscow and the Soviet counteroffensive threatened to overwhelm the German Army 
since it was unprepared for winter operations. Hitler forbid a general retreat which under the winter conditions probably saved the Wehrmacht from the fate of the Grande Armee in 1812. He ordered the Wehrmacht to stand fast. General Bock of Army Group Center was ordered to cease all withdrawals and defend its present positions. Hitler ordered that German soldiers were to follow his dictum: "not one single step back." 3 General withdrawal was declared out of the question. The stand fast orders established the framework of German defensive strategy under Hitler. The successful outcome of the stand fast policy in the winter of 1941 . 42 persuaded Hitler that his own instincts were superior to the collective wisdom of the front commanders and the General Staff. Will and determination replaced sound strategy. Hitler would order troops to stand fast against impossible odds and this resulted in needless loss of precious manpower in the Wehrmacht.

General Jodl described Hitler's actions after Stalingrad as follows:

From then on, he intervened more and more frequently in operational decisions often down to matters of tactical detail, in order to impose with unbending will what he thought the generals simply refused to comprehend: that one had to stand or fall, that each voluntary step backwards was an evil in itself. ${ }^{4}$

Field Marshal Erich Von Manstein described Hitler's belief in will:

The will for victory which gives a commander the strength to see a grave crisis through is something very different from Hitler's will which in the last analysis 
stemmed from a belief in his own "mission." Such a belief inevitably makes a man impervious to reason and leads him to think that his own will can operate beyond the limits of hard reality-whether these consist in the presence of far superior enemy forces, in the conditions of space and time, or meeting in the fact that the enemy also happens to have a will of his own. 5

Thus, the Fuehrer's fundamental principle was "to remain at all costs, on ground which has once been won." The new defensive tenet became "an inflexible stand." This principle according to General Blumentritt became responsible for the severe handicap under which German Commanders had to operate after 1941. According to Blumentritt, "without free, independent strategic resposibility--uninfluenced by pressure and fear--no general is in a position to gain successes in the field." 6 Furthermore, the Fuehrer even forbid the establishment of defensive lines in the rear which could have been established to free reserves for a more mobile defense. Hitler apparently believed that defensive lines in the rear exerted a magnetic force on soldiers, and that they should never be tempted by prematurely establishing defense lines behind them. ${ }^{7} \mathrm{He}$ believed soldiers would fight harder knowing there were no defensive lines to the rear, and this corresponded to his conception of the stand fast policy.

\section{HITLER'S WAVEBREAK DOCTRINE}

The stand fast doctrine was supplemented by what Percy Schramm, the writer of the OKW war diary, called the wavebreak 
doctrine in 1944.8 This doctrine tied the hands of the army commanders even further making it even more difficult to conduct an elastic defense. On March 8, 1944, Hitler issued Fuehrer Order No. 11:

In view of various incidents, $I$ issue the following orders:

1. A distinction will be made between Fortified Areas [feste Plaetze], each under a Fortified Area Commandant, and Local Strong-points [Ortsstuetzpunkte], each under a Battle Commandant.

The Fortified Areas will fulfil the function of fortresses in former historical times. They will ensure that the enemy does not occupy these areas of decisive operational importance. They will allow themselves to be surrounded, thereby holding down the largest possible number of enemy forces, and establishing conditions favourable for successful counterattacks. ${ }^{9}$

Based upon the above directive a whole series of fortresses were established in the East. Hitler's assumption was that the enemy required more forces to lay siege to the fortresses than were required for the defense. This presupposed that the enemy would have to take these fortresses, since he would require the road junctions and railway depots. In fact, the Soviets bypassed fortresses and surrounded others with inferior units. ${ }^{10}$ The Germans, on the other hand, tied up critical numbers of troops which were then later sacrificed in needless encirclements instead of being conserved and used in an elastic defense. 
ELASTIC DEFENSE AND STRATEGIC WITHDRAWAL:

THE LAST HOPE OF ARMY GROUP CENTER

Elastic defense is the application of depth, maneuver, firepower and counterattack to exhaust the attacker in the depth of the defense. Figure 11 delineates the concept of elastic defense as found in the Truppenfuehrung manuel. The Germans were strong enough in 1944 and possessed sufficient maneuvering space in Belorussia to apply an elastic defense to wear down the Soviets. General Wladyslaw Anders provides a description of the tactics of elastic defense:

This defense consists of the alternative use of premeditated retreat and sudden counter-stroke. The retreat enables the defender to avoid the blows of the attacker and to draw him on, while a sudden counterattack holds the chance of defeating the aggressor at the moment when his offensive begins to peter out. These tactics prove practicable if the defender has superiority over the attacker in both command and mobility. ${ }^{11}$

Therefore, Field Marshal Busch presented two alternatives of conducting an elastic defense: "kleinen Loesung" (Dnjepr Solution) and "grossen Loesung" (Beresina Solution). ${ }^{12}$ The first solution was a rearward adjustment to a relatively tankproof position which had been prepared along the line Polotsk--west of Vitebsk--the Dnjepr at Orsha--Mogilev. This solution would require a withdrawal of 55 kilometers and would shorten the front by 80 kilometers. The second solution was more sweeping involving a withdrawal behind the largely marshy length of the river Berezina between Polotsk 
and Bobruisk (see Figure 12). ${ }^{13}$ This would require a withdrawal of 140 kilometers and would shorten the front by 160 kilometers.

Field Marshal Busch proposed executing a withdrawal just prior to the Soviet summer offensive which would then require the Soviets to conduct an additional time consuming approach march to the next German defensive line. Both the "kleinen Loesung" and the "grossen Loesung" were part of an overall elastic defense plan which could grind down the Soviet offensive momentum, but would require the sacrifice of territory something that was unacceptable to Hitler. Hitler responded with the "Fuehrerbefehl Nr. 11. He declared certain cities in the area of Army Group Center "Festen Plaetzen": Bobruisk, Mogilev, Orsha, Vitebsk and Minsk (see Figure 13). ${ }^{14}$ This decision by Hitler tied up large numbers of troops in exposed positions that could be encircled thereby depriving Army Group Center of sufficient forces to adequately conduct an elastic defense. The demand by Hitler to hold Vitebsk which was the most tenuous of the cities prompted Field Marshal Busch to ironically declare according to the Fuehrer: "Our prestige is at stake! Vitebsk is the only Eastern Front town whose loss will cause the world to sit up and take notice."15

On May 20, 1944, Field Marshal Busch approached Hitler about shortening the front to strengthen the defense. Hitler accused Busch of "being another General who spent their whole time looking over their shoulder."16 Busch responded to Hitler's intimidation by mindlessly carrying out his instructions to execute a rigid positional defense. Busch held a conference on May 24, 1944 and 
instructed the army commanders and the Commander-in-Chief of Luftflotte 6 regarding Hitler's demand to hold the existing line at all costs. ${ }^{17}$ He demanded that all available effort be used to prepare the army group's present positions. Nevertheless, army commanders still insisted on operational freedom of action once the offensive began. But Busch had given up attempting to exercise independence from the Fuehrer's will and his headquarters obeyed the Fuehrer's orders to hold the front exactly where it was. The army commanders later found it necessary to undertake actions without support of the Commander of Army Group Center.

\section{THE LOST POTENTIAL OF ELASTIC DEFENSE}

Army Group Center in March 1943 had withdrawn appproximately 100 miles to the west because it was in an overexposed position. This withdrawal reduced a 530 kilometer front to 200 kilometers. The shrinkage of the front produced a reserve of 15 infantry divisions, two motorized infantry divisions, three panzer divisions, one SS cavalry division and several headquarters units. ${ }^{18}$ The withdrawals of 55 and 140 kilometers proposed by Field Marshal Busch would shorten the front only $\mathbf{8 0}$ and 160 kilometers respectively. Therefore, the corresponding number of divisions released as reserves would be much less. However, Army Group Center was in desperate need of reserves. The entire army group only had one Panzer division and three Panzer 
Grenadier divisions as mobile forces. Any infantry divisions that could have been pulled out of the front line for use as reserves would have improved the situation at the front.

The German Army was forced to fight in total defiance of basic principles of war which had been recognized in the eighteenth century. Clausewitz had defined the principles of defensive war which had influenced German thinking:

He holds his position in depth for at every level from division to battalion, his order of battle has reserves for unforseen events and to renew action. A substantial reserve, however--perhaps one quarter or one third of his whole force--is kept far to the rear, far enough to avoid any casualities from enemy fire and, if possible far enough to remain outside any possibility of envelopment. This reserve is meant to cover his flanks against any wider and larger turning movement and to protect him against the unexpected. In the final third of the battle, when the enemy has revealed his whole plan and spent the major part of his forces, the defender intends to fling this body against a part of the enemy forces, thus opening a minor offensive battle of his own using every element of attack--assault, suprise and flanking movements. All these pressures will be brought to bear on the battle's center of gravity while the outcome still hangs in the balance in order to produce a total reversal. ${ }^{19}$

Thus, Hitler defied military reality which had been recognized since the eighteenth century and supplanted it with the psychological principle of "will."

Even the Red Army expected the Germans to pursue a more rational defense. Colonel N. Loshchagin and Colonel A. Melnichuk writing in Krasnaya Zvezda (Red Star) on June 17, 1944 stated: 
The German command has a tendacy to have strong reserves, even at the cost of weakening the troops at the front. On the Soviet-German front the operational reserves average from one to three divisions in armies, and from two to five divisions in army groups. They are employed in a strictly centralized manner. 20

Furthermore, in defensive operations Germans were noted to have most of their operational reserves composed of mobile forces such as Panzer and Panzer Grenadier divisions which were to be used en masse to liquidate breakthroughs and stabilize the front. However, Army Group Center lacked the mobile reserves because these had been allocated to Army Group North Ukraine and France. The Army Group held a front of 1100 kilometers with 40 divisions (see Figure 14). ${ }^{21}$ This amounted to each division holding about 25 kilometers. This amounted to three to four times the frontage previously regarded as acceptable for a successful defense.22 Army Group Center also lacked heavy artillery, assault guns and antitank weapons to block possible tank approaches. Hitler's refusal to develop more defensive positions in depth caused a rigidity of defense because once the main defenses had been breached there were no series of defensive lines prepared to fall back on throughout Belorussia (see figure 15).

General Kurt Von Tippelskirch, Commander of the 4th Army, reported that all army commanders in Army Group Center begged for permission to withdraw to the Beresina line. This withdrawal would have taken the punch out of the Soviet offensive, but all such suggestions were rejected. Nevertheless, Tippelskirch displayed 
initiative despite Hitler's orders. He withdrew his forces back to the Dnieper on his sector, and this action allowed him to keep his front intact. But the fronts of the other armies to his north and south were ruptured producing a general collapse. Tippelskirch made the following assessment:

It would have been much wiser strategy to withdraw the whole front in time. The Russians always needed a long pause for preparation after any German withdrawal, and they always lost disproportionately when attacking. A series of withdrawals by adequately large steps would have worn down the Russian strength, besides creating opportunities for counter-strokes at a time when the German forces were still strong enough to make them effective...

The root cause of Germany's defeat was the way that her forces were wasted in fruitless efforts, and above all in fruitless resistance at the wrong time and place. That was due to Hitler. There was no strategy in our campaign. 23

Finally, defenders of Hitler's stand fast policy and critics of elastic and mobile defense argue that the loss of more territory in a mobile defense was hardly preferable to a static defense which produced the same result. ${ }^{24}$ However, what these apologists such as Martin Van Creveld overlook in Hitler's conduct of the war is the fact enormous amounts of men and material could have been conserved which then would have been available for reserves to prevent the collapse of the front which occurred numerous times as a result of Hitler's stand fast policy. General Heinz Guderian summed up the situation: 
The more critical the situation became, the more inflexible became the attitude of the German Command. The advanced positions had to be defended foot by foot, until encirclement. Heavy losses in personnel and material were suffered as a result. 25 


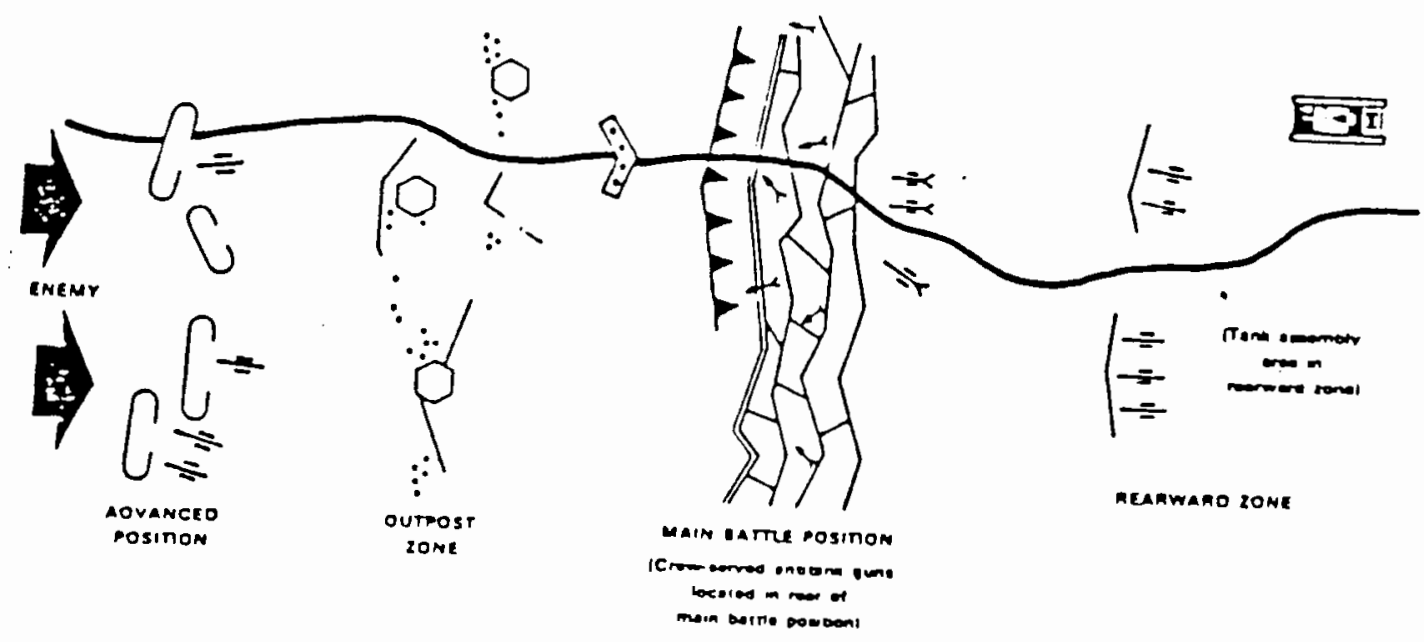

Figure 11. German Elastic Defense, 1933. Source: Major Timothy A. Wray, Standing Fast: German Defensive Doctrine on the Russian Front During World War II (Washington D.C.: U.S. Government Printing Office, 1986), p. 15. 
81

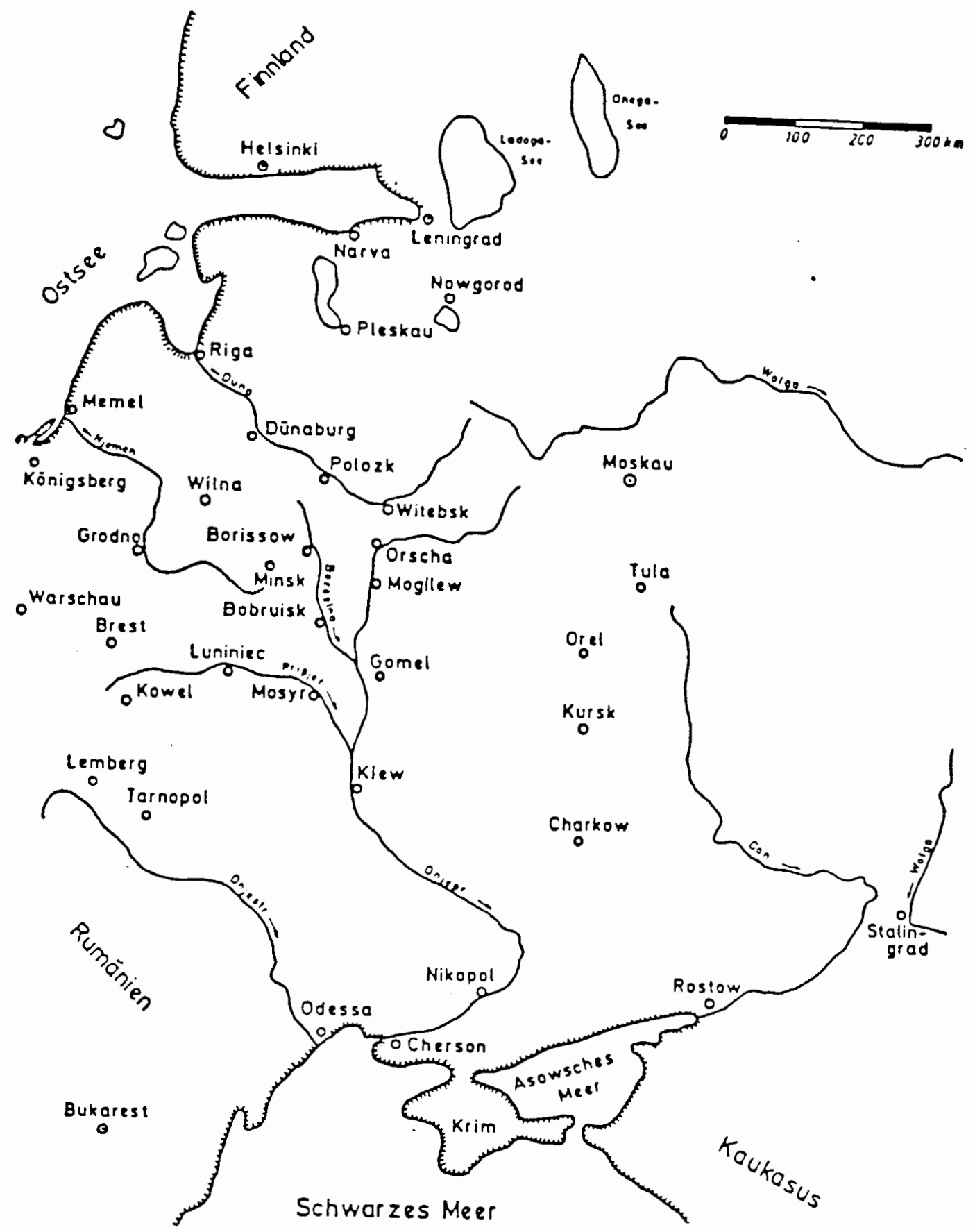

Figure 12. Western Russia. Source: Rolf Hinze, Der Zusammenbruch der Heeresgruppe Mitte im Osten 1944 (Stuttgart: Motorbuch Verlag, 1980), p. 10. 


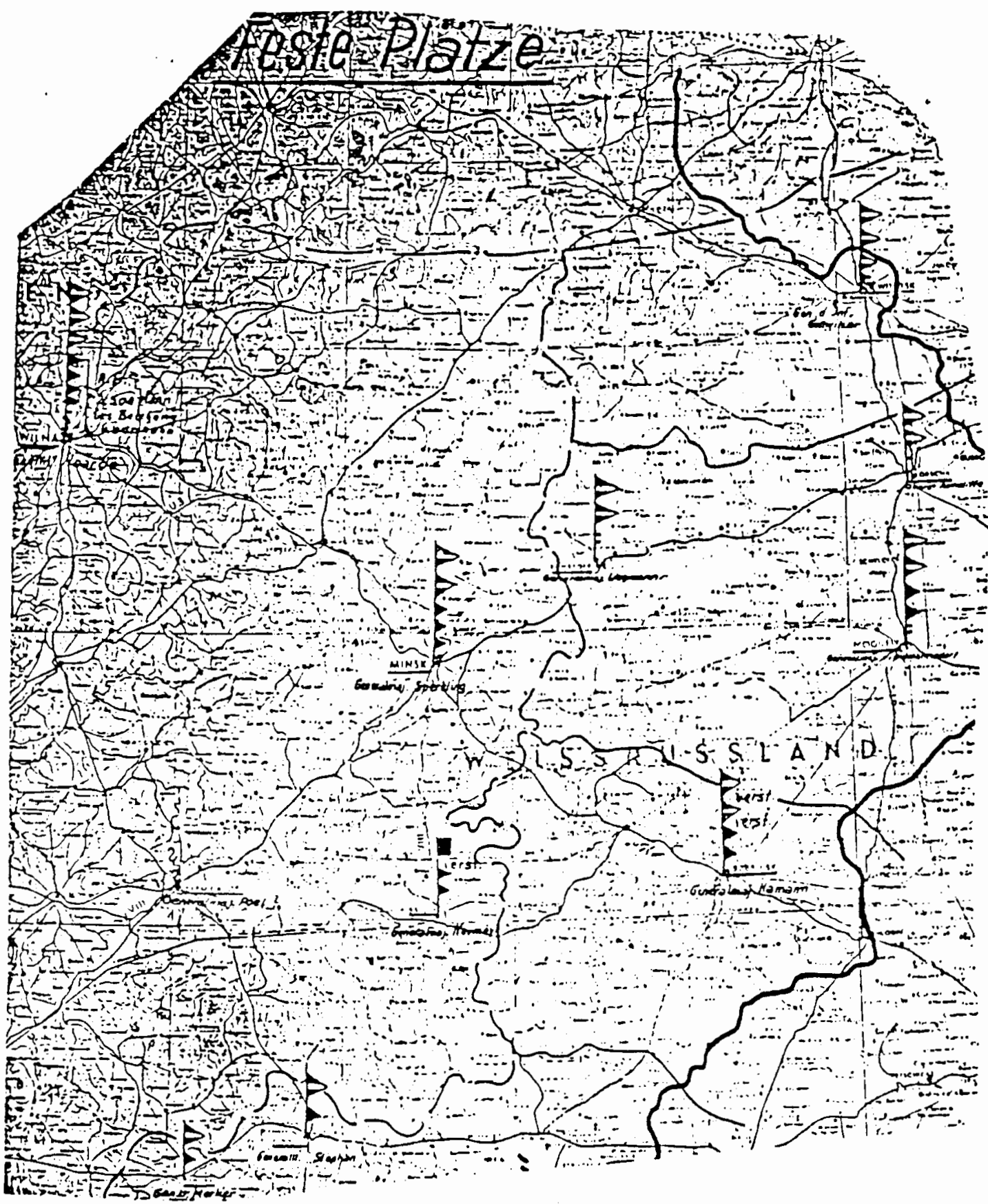

Figure 13. Fortresses In White Russia. Source: Oberkommando H. Gr. Mitte, Feste Plaetze National Archives Microfilm Publication T-311, Roll 228. 


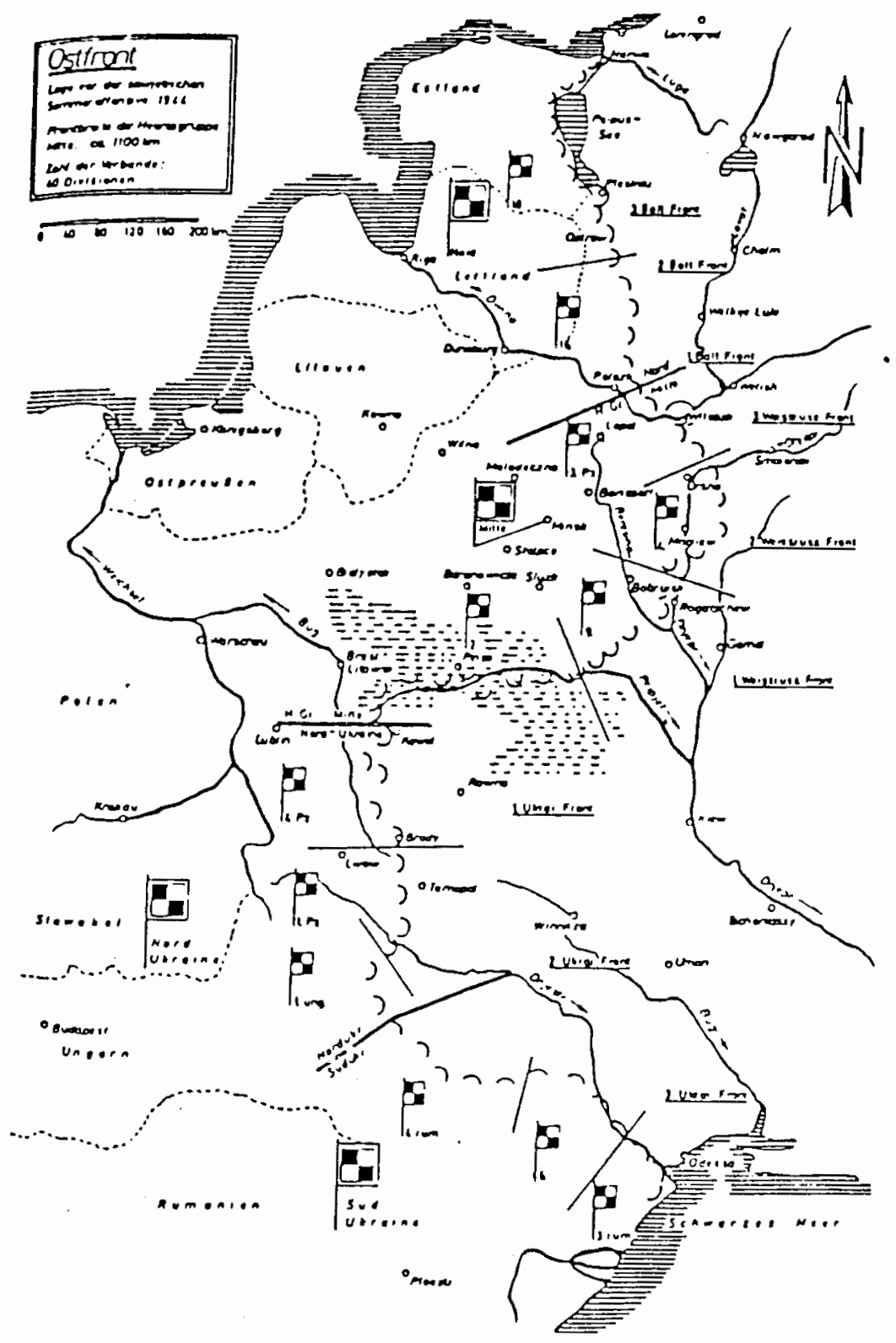

Figure 14. Ostfront. Source: Rolf Hinze, Der Zusammenbruch der Heeresgruppe Mitte im Osten 1944 (Stuttgart: Motorbuch Verlag, 1980), p. 19. 


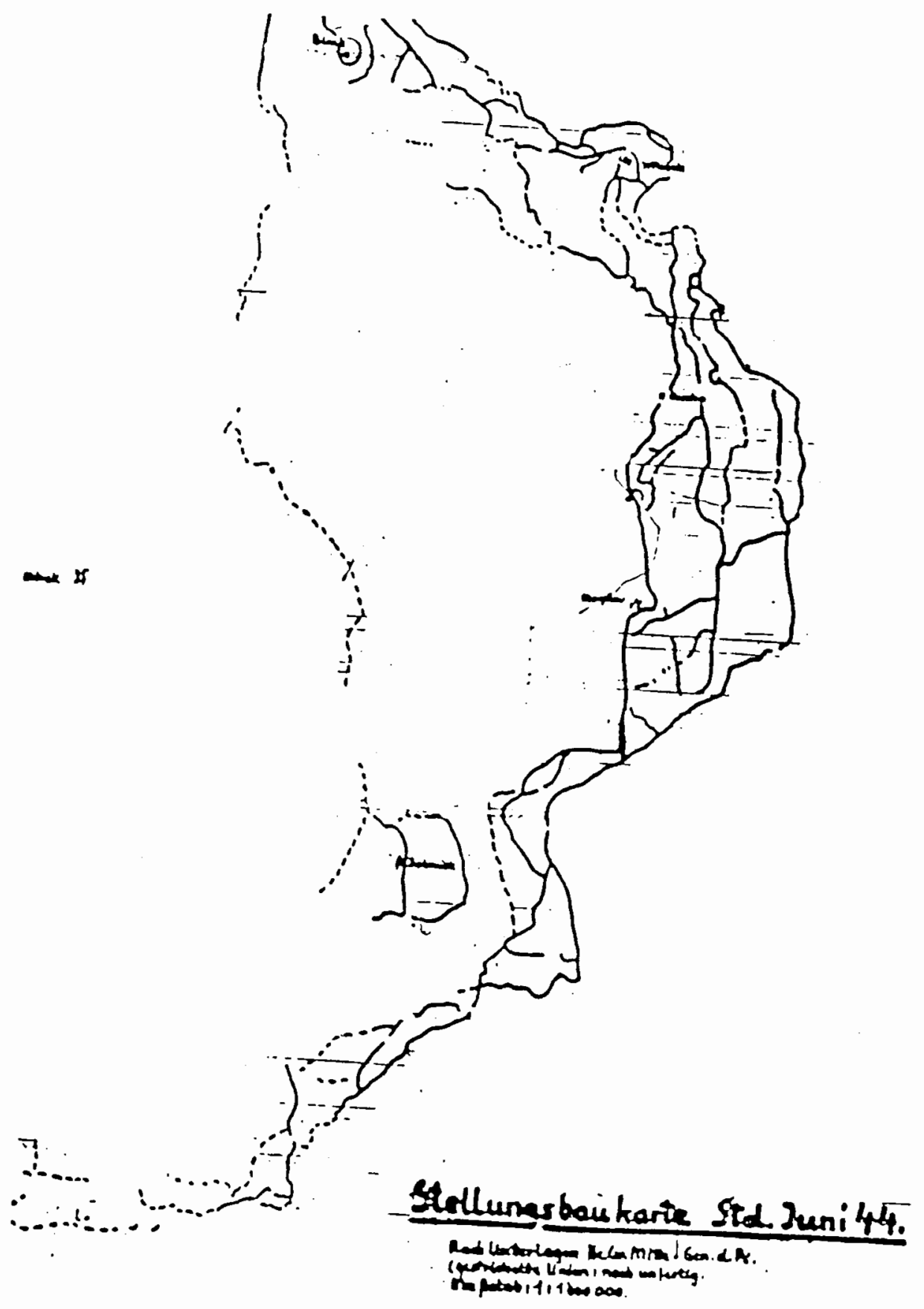

Figure 15. Stellungsbaukarte, June 1944. Source: National Archives Microfilm Publication T-311, Roll 219. 


\section{NOTES TO CHAPTER III}

${ }^{1}$ Major Timothy A. Wray, Standing Fast: German Defensive Doctrine on the Russian Front During World War II (Washington D.C: U.S. Government Printing Office, 1986), p. 171. 508.

2Paul Carell, Scorched Earth (London: George G. Harrap \& Co. LTD, 1970), p.

3 Wray, p.62.

4Percy Ernst Schramm, Hitler: The Man And The Military Leader (Chicago: Quadrangle Books, 1971), p. 110.

${ }^{5}$ Field Marshal Enich Von Manstein, Lost Victories (Novato, Californa: Presidio Press, 1982), p. 227.

6General Guenther Blumentritt, "Strategic Withdrawals," Military Review September, 1953, p. 32.

7Percy Ernst Schramm, Hitler: The Man And The Military Leader, p. 152.

8/bid., p. 158.

${ }^{9}$ H.R. Trevor-Roper, Hitler's War Directives 1939-1945 (London: Pan Books Ltd, 1966), p. 234.

10Percy Ernst Schramm, Hitler: The Man And The Military Leader, p. 158.

11 General Wladyslaw Anders, Hitler's Defeat in Russia (Chicago: Henry Regnery Company, 1953), p. 155.

12Hinze, Der Zusammenbruch der Heeresgruppe Mitte Im Osten 1944, p. 18.

${ }^{13}$ Niepold, Battle For White Russia: The Destruction of Army Group Centre June 1944, p. 13.

${ }^{14}$ Hinze, Der Zusammenbruch der Heeresgruppe Mitte Im Osten 1944, p. 18.

15/bid., p. 25.

${ }^{16}$ Niepold, Battle For White Russia: The Destruction of Army Group Centre June 1944, p. 14.

17 lbid. 
${ }^{18}$ Colonel-General Kurt Zeitzler, "Withdrawals of the German Army on the Eastern Front," Military Review August 1960, p. 82.

${ }^{19} \mathrm{Carl}$ Von Clausewitz, On War (Princeton, N.J.: Princeton University Press, 1976), p. 391.

${ }^{20}$ Colonel N. Loshchagin and Colonel A. Melnichuk, "Employment of Operational Reserves in the German Army," Military Review December 1944, p. 85.

${ }^{21}$ Generalmajor Peter Von der Groeben, "Collapse of Army Group Center And Its Combat Activity Until Stabilization of the Front," World War II German Military Studies Vol. 16 ed. Donald S. Detwiler, Charles B. Burdick and Juergen Rohwer (New York: Garland Publishing, Inc., 1979), p. 7.

22Ibid.

${ }^{23}$ B.H. Liddell Hart, The German Generals Talk (New York: William Morrow \& Co., 1948), pp. 217-218.

${ }^{24} \mathrm{M}$. Van Creveld, "War Lord Hitler: Some Points Reconsidered," European Studies Review Vol. 4 No. 1 January 1974, p. 75.

25General Heinz Guderian, "The Experiences of the War in Russia," Military Review, July 1957, p. 96. 


\section{CHAPTER IV}

\section{AIRPOWER: THE LUFTWAFFE LOSS OF SUPERIORITY}

The loss of air superiority on the Eastern Front was a result of fragmentation of Luftwaffe efforts in an ever widening war and the numerical and qualitative increase in the Soviet Air Force. The massive losses suffered by the German Army in the East required the Luftwaffe to concentrate its effort in ground support operations which prevented the strategic use of its assets against the Soviet Union. Essentially, the Luftwaffe air units had become "Fire Brigades" in support of a Wehrmacht in trouble." Luftwaffe General Hermann Plocher described the Luftwaffe dilemma this way:

Dispersal of its forces was the cardinal weakness of the Luftwaffe in these operations. No longer did German air units go ahead of the advancing ground forces. Instead, they were rapidly shifted from side to side wherever a crisis developed, often arriving too late to alleviate the danger. This continual transferring of air units was a result of numerical weakness in German air strength and the Luftwaffe's consequent inability to accomplish its missions all along an extended front. ${ }^{2}$

The Luftwaffe was placed at an increasing disadvantage as the war progressed. The Italian/Balkan front, the Western front 
and the air defense of the Reich siphoned off aircraft that would have potentially been available for combat on the Eastern front.

The multi-front problem was described by the Military History

Division of the Luftwaff General Staff in a 1944 study:

The Luftwaffe was no longer as in the past employed in concentration on only one front against only one enemy within the overall pattern of the whole war. Through its employment in a number of theaters simultaneously, it was compelled to dispatch its forces against the enemy in widely seperated areas. This necessarily resulted in a reduction of operable strengths available in the individual segments of the fronts. ${ }^{3}$

General der Flieger a. D. Paul Deichmann addressed the strategic failure of the Luftwaffe:

Because of its inferior strength, the strategic Luftwaffe was forced out of its real role in spite of a clear realization of the adverse results which would follow. Neither in Russia, nor in the Mediterranean and western theaters did German air superiority continue. As a result the initiative passed more and more to the enemy. Our own forces, however, found themselves implicated in air defense under the pressure of events of the war. 4

\section{LUFTWAFFE: STRATEGIC AIR WARFARE IN THE EAST}

Two main problems plagued the Luftwaffe in the East. The failure to conduct strategic warfare against the Soviet Union and the lack of a central command structure to unify and concentrate Luftwaffe resources. The strategic warfare issue had to be 
addressed early in the war to prevent the full weight of Soviet industry and resources from being utilized in the war effort.

The Luftwaffe Field Directive on the conduct of air warfare described three missions for the Luftwaffe:

1. Through combat against enemy air forces, the Luftwaffe weakens the enemy's military strength and thereby protects its own military forces, its civilian population, and its country.

2. Through intervention in operations and combat on the ground and at sea, the Luftwaffe provides direct support for the Army and Navy.

3. Through warfare against the sources of enemy military strength and through cutting off communication between these sources and the front, the Luftwaffe seeks to subdue the enemy force. ${ }^{5}$

Therefore, the Luftwaffe regarded strategic warfare as at least as important as the other two missions of the Luftwaffe. However, this was not recognized by $\mathrm{OKW}$ and $\mathrm{OKH}$. The German Air Force became tied to Army support when the goals should have been the destruction of the Soviet Air Force, armament works and the transportation network. 6 Even the production of aircraft indicated the lack of a strategic outlook. The Germans lacked a long range four-engine bomber and the plans for a "Ural bomber" had been dropped during 1936.7 The Luftwaffe as a result never had a satisfactory long-range bomber before or during the war. ${ }^{8}$

Finally, in late 1943 the Luftwaffe was to commence strategic bombing operations against the Soviet Union but it was already too late. The suicide of General Hans Jeschonnek, Chief of 
the General Staff of the Luftwaffe resulted in the promotion of General Guenther Korten to this position in September 1943. Korten initiated reforms to reduce Luftwaffe operations in support of the army. His goals were the creation of a strategic bomber force and a strategic fighter defense. ${ }^{9}$ Korten's reforms, however, weakened the Eastern Front. Zerstoerergeschwader 26 and 76 (twin-engine fighter units) and Jagdgeschwader $3,11,53$ and 27 were recalled from the Eastern Front for defense of the Reich.10 A Geschwader normally contained 150 aircraft. 11 But it is doubtful if these Geschwader were at full strength. On November 26, 1943, General Korten issued the directive which created a strategic bomber force known as IV Air Corps. The mission of this Air Corps was stated in the directive:

In order to carry out systematic bombardment of Russian armament industries, $I$ intend to unite the majority of the heavy bomber units assigned in the East--together with other special duty bomber units-under the command of the Headquarters, IV Air Corps.

These units will be assigned the mission of conducting air attacks against the Russian armaments industry with a view to destroying Soviet material resources-tanks, artillery, and aircraft--before they can be put to use at the front. In this way, the Luftwaffe will be able to provide greater relief for our hard pressed Eastern armies than by its commitment in groundsupport operations alone.12

In December 1943, eight bomber Gruppen were withdrawn from the Eastern Front and assigned to Flieger Korps IV which became independent of Luftflotte 4 with 250 aircraft for strategic 
employment. ${ }^{13}$ Previously, these bomber aircraft had not only been used for combat operations in a ground-support role but also served as troop carrying transports. ${ }^{14}$

The Minister of War Production and German Intelligence produced a comprehensive plan for attacking Soviet industry and resources. It was calculated that by selective bombing of key targets that $50-80$ percent of Soviet productive capacity could be eliminated. ${ }^{15}$ German Intelligence estimated that such bombing could eliminate 3,500 tanks and 3000 front-line aircraft per month. ${ }^{16}$ The new strategic thinking followed this reasoning:

Each Russian tank, each gun, each airplane, each railway locomotive which could be destroyed while still in the factory saved the German Army serious losses...a single successful air attack on the Russian tank factories would have destroyed the product of several weeks' work all at once and would have been sufficient to stop any further production for some time. It is difficult to stop a rushing stream; its source, however, can be dammed up with relatively little effort. ${ }^{17}$

During the spring of 1944 , the Flieger Korps IV conducted a series of attacks and some participants described the results as successful. ${ }^{18}$ However, 1944 was too late to begin strategic bombing with any hope of success. The fallacy of strategic bombing at this time was that the German lines had been pushed back so far that a major portion of the targets were out of range to German bombers. ${ }^{19}$ The aircraft engine works in Kuybishev, Kasas, and Ufa were critical to the increased production of Soviet aircraft. 20 However, these production centers were outside the 
range of German bomber aircraft and attacks had to be restricted to the Moscow-Yaroslavl area (see Figure 16). ${ }^{21}$

Luftwaffe General Deichman made the following observation concerning the belated attempts at strategic warfare on the Eastern Front:

The attempt to achieve lasting results by means of strategic air operations was nevertheless repeated frequently. Attacks were directed occasionally at militarily important factories in Gorki, Jaroslavl, Rybinsk, Moscow, and Leningrad. However, no telling results were achieved because the forces dispatched were too small and because the attacks took place at too long intervals. 22

In fact, the withdrawal of these Bomber Geschwader from ground support only served to accelerate the loss of territory on the Eastern Front.23 In March 1944, the IV Air Corps had a strength of 350 bombers consisting mostly of $\mathrm{He}-111$ 's and Ju-88's. ${ }^{24}$

The collapse of Army Group Center brought an end to strategic air operations in the East. The last strategic operation of IV Air Corps coincided with the beginning of the main Soviet summer offensive, Operation Bagration. The Luftwaffe's last strategic victory in the East was not against the Soviets, but surprisingly against the Americans. On June 21, 1944, the Americans landed 140 B-17's at Poltava and 56 P-51's at Mirgorod airfields (see Figure 17). 25 The IV Air Corps was ordered to destroy the American force. The Germans successfully bombed Poltava on June 22, 1944 and destroyed 47 B-17's and damaged 26 without a single German loss. ${ }^{26}$ Thus, ended the Strategic Air 
Force on the Eastern Front because with the coming of the Soviet summer offensive the German army desperately needed every aircraft in ground-support operations to stave off further collapse.

Flieger Korps IV was disbanded to provide ground support

\section{LUFTWAFFE AND SOVIET COMMAND AND CONTROL}

Another major problem for the Luftwaffe was the lack of coordination and concentration of its air power. The Luftwaffe was divided into several Luftlotten on several fronts (see Figure 18). The Luftflotten constituted the central organization of the Luftwaffe in its command structure (see Figure 19). Luftflotten were in fact independent air fleets. However, these Luftflotten were tied to the support of the German Army (see Figures $20 \& 21$ ). This was especially true in the East where these air fleets were committed deep in enemy territory which dissipated the air strength of the Germans. Luftwaffe General Deichman stated the solution to this problem:

After 1941 it would have been wise to withdraw the bomber wings from control by the individual air fleet headquarters and place them under suitable command staffs under a centralized bomber command. This was the only possible way to secure their commitment in concentration at decisively important points when necessary in support of the Army. Only if this had been done would the Luftwaffe have been in a position to exercise a decisive influence on military events. ${ }^{27}$ 
However, the Germans realized this only after it had become too late in 1944 to effect the course of events on the Eastern Front.

The Soviet Air Force (VVS: Voenno-vozdushnye sili) recovered from its disastrous defeats in 1941 and 1942 to gain numerical superiority over the Luftwaffe by the end of 1943 . The Soviets deployed 13 air armies on the German-Soviet Front: 1st, 2nd, 3rd, 4th, 5th, 6th, 7th, 8th, 13th, 14th, 15th, 16th, and 17th Air Armies. ${ }^{28}$ Each air army contained approximately 660 aircraft.29 Therefore, 13 air armies at full strength would contain 8,580 aircraft as compared to 2,312 aircraft deployed by the Germans on the Eastern Front. ${ }^{30}$ The Soviet Air Force was to increase its strength further in 1944 with increased aircraft production and lend lease aircraft. Meanwhile, Luftwaffe strength was dissipated on several fronts which prevented its forces from being used in a decisive manner against the Soviet Air Force. This resulted in a loss of air superiority on the Eastern Front during the summer of 1944 which proved critical to the German defeat.

\section{NUMERICAL COMPARISON OF THE LUFTWAFFE AND THE SOVIET AIR FORCE}

The Luftwaffe maintained an average of $42.8 \%$ of its total strength on the Eastern Front from August 1943 to November 1944. ${ }^{31}$ The number of Aircraft on the Eastern Front averaged 2,881 between August 1943 and November 1944.32 These statistics delineate the dilemma of the Luftwaffe fighting on 
several fronts. The Luftwaffe could not even concentrate half its strength on the Eastern Front. In August 1943, the Luftwaffe aircraft strength was distributed to the various fronts as delineated in Table II. In June 1944, Luftwaffe aircraft strength was deployed as listed in Table III

The Luftwaffe in August 1943 had $56.4 \%$ of its forces against the Anglo-American forces in the West. The situation remained approximately the same in June $1944 ; 56 \%$ of the Luftwaffe continued to be engaged in the West. Therefore, the Soviet Air Force only had to engage less than half of the total available German airpower. This aided the Soviets in gaining air superiority on their only front. Meanwhile, the Germans were spread thin on six different fronts.

The Luftwaffe strength on the Eastern Front was divided between the various Luftflotten (see Figure 22). In June 1944, the various types of aircraft were distributed in the Luftflotten as delineated in Table IV. Table IV also reveals the lack of combat aircraft that could be used to counter the Soviet summer offensive. Luftflotten 5, 1, 6, and 4 constituted the Luffflotten of the Eastern Front (see Figure 22). The four Luftflotten of the Eastern Front contained 3,267 aircraft in June 1944. However, this figure is deceptive because only $61 \%$ of the aircraft were combat aircraft. The following analysis shows the actual combat strength as delineated in Table IV: 
Single-Engine Fighters:

LF $5 \quad 29$

LF $1 \quad 91$

LF $6 \quad 137$

LF $4 \quad \frac{151}{408}$

Total: $\quad 408$

Night Fighters:

LF $5 \quad 0$

LF $1 \quad 5$

LF $6 \quad 47$

LF $4 \quad \underline{45}$

Total: $\quad 97$

Twin-Engine Fighters: LF 519

LF $1 \quad 0$

LF $6 \quad 0$

LF $4 \quad \underline{0}$

Total: $\quad 19$

Ground Attack

Aircraft:

LF $5 \quad 10$

LF 1

LF $6 \quad 152$

LF $4 \quad 374$

Total: $\quad 610$

Night Ground Attack

Aircraft:

LF $5 \quad 22$

LF $1 \quad 201$

LF $6 \quad 72$

LF $4 \quad \underline{97}$

Total: 392

Bomber Aircraft: LF 50

LF 19

LF $6 \quad 398$

LF $4 \quad \underline{55}$

Total: $\quad 462$

Total Combat Aircraft on the Eastern Front:

1,988

Even the 1,988 combat aircraft employed in the four Eastern Front Luftflotten does not reveal the complete picture of 
Luftwaffe weakness. This figure accounts for aircraft but does not indicate the operational status of the aircraft. Many aircraft were not operational because of needed repairs. Furthermore, when the Normandy invasion began 50 single-engine fighters were transferred from the central front to Germany. ${ }^{33}$ Bombers were also routinely used as transports instead of in a strategic bombing or close support role. 34

The lack of single-engine fighters in the East assured the Soviet Air Force of gaining superiority. The increased production of single-engine fighters (see Figures $23 \& 24$ ) was absorbed by the Anglo-American Fronts. Table IV denotes a single-engine fighter strength of 1,104 on the Anglo-American Fronts as compared to 408 on the Eastern Front. Therefore, the Luftflotten of the Eastern Front lacked fighter reserves and was forced to fight with an inadequate number of aircraft at a time of Soviet numerical superiority in the air and on the ground.

On July 3, 1944, the collapse of Army Group Center caused a redeployment of Luftwaffe resources to help plug the gaping hole in the front in Belorussia. Aircraft were thrown in from various fronts to stabilize the situation. Luftflotte Reich transfered 40 single-engine fighters to the central front. The Italian front yielded $85 \mathrm{FW} \mathrm{190's} \mathrm{and} 40 \mathrm{FW} 190$ 's were taken from the critical Normandy front. Another $70 \mathrm{FW} 190$ 's were transferred from Luftflotte 4 to Luftflotte 6 . Luftflotte 4 was nearly stripped of all ground attack aircraft by the end of July 1944.35 In June 1944, Luftflotte 4 contained 374 ground attack aircraft, but by August 
1944 it retained only 59 ground attack aircraft (see Table IV \& Table V).

The catastrophes on the Eastern Front did increase the overall percentage of Luftwaffe strength deployed in the East. In August 1944, $46.5 \%$ of German aircraft were employed on the Eastern Front compared to $44 \%$ in June 1944. However, the actual numbers of aircraft deployed shrank because the number of Luftwaffe aircraft after replacements declined by 1,078 aircraft in two months. ${ }^{36}$ This indicated heavy Luftwaffe losses during this summer period. In June 1944, 3,267 aircraft were on the Eastern Front in Luftilotten 5, 1, 6, and 4 compared to 2,948 in August 1944 (see Tables IV \& V).

The Soviet Air Force according to Luftwaffe Commanders had achieved a large numerical superiority in air power by the end of 1943.37 This superiority increased continually till the end of the war. Meanwhile, the Luftwaffe was forced onto the defensive with decreasing operable strength in front line units compounded by a growing German shortage of fuel (see Figure 25). ${ }^{38}$ Nevertheless, the Germans assert that absolute air superiority was not achieved by the Soviets because Soviet fighter pilots remained inferior to their German counterparts in air combat. ${ }^{39}$ This inferiority allowed German bomber and dive-bomber units to execute their assigned missions. Therefore, the Luftwaffe could assert local air superiority for brief periods of time, but overall lacked air superiority since the Germans could not prevent the Soviet Air Force from executing its primary function of ground support. 
The quality of Soviet aircraft almost equalled the Germans by the summer of 1944.40 Numerically, the Soviets had clearly surpassed the German Luftwaffe. The Soviet Air Force or VVS (Voenno-vozdushnye sili) grew in strength from 8,818 aircraft in January 1944 to 14,787 aircraft by June 1944.41 This amounted to an increase of 5,969 aircraft or a $68 \%$ increase in strength. The twelve frontal air armies contained 8,798 operational combat aircraft and 1,046 R-5 and PO-2 light night bombers. 42 Therefore, the Soviets had achieved more than a 7:1 advantage in total aircraft, 6:1 in operational aircraft, and more than 10:1 in fighters when compared to the operational front line strength of 2,085 aircraft. 43

\section{THE LUFTWAFFE ANTI-TANK SUPPORT}

The effect of Soviet dominance in the air proved deterimental to the Luftwaffe and to the Wehrmacht. It became extremely hazardous for JU 88, HE 111 and JU 87 aircraft to operate except at night. 44 The Wehrmacht which could formerly call on the "Fire Brigades" of the Luftwaffe for assistance was put under even greater pressure by the lack of Luftwaffe support and the increased attacks by the Soviet Air Force. The HS 129 and JU 87G had been important ground attack aircraft which had been in the past used to destroy Soviet tank formations. ${ }^{45}$ The JU 87G was equipped with two $3.7 \mathrm{~cm}$ cannon and the HS 129 was fitted with a 
$3 \mathrm{~cm}, 3.7 \mathrm{~cm}$ or $7.5 \mathrm{~cm}$ cannon. 46 These anti-tank cannons all fired solid-shot armor-piercing rounds. The most outstanding examples of this air support occurred during the summer of 1943 in Operation Zitadelle (see Figures $26 \& 27$ ). 47

However, this powerful striking force had its effectiveness reduced with the advent of massive Soviet aerial supremacy. The Panzerjaegerstaffeln were employed in the spring of 1944 to contain Soviet armored breakthroughs in the Ukraine (see Figure 28). These units suffered heavy losses during the Soviet spring offensive.48 Focke Wolfe 190's were adapted to the ground support role by equipping them with rockets known as Panzerschreck and Panzerblitz. ${ }^{49}$ In 1944 the production of FW 190's increased to allow conversion of the Schlachtgeschwader from JU 87 to the FW 190. The rate of conversion was 2 Gruppen every six weeks. Therefore, only one Gruppe (53 aircraft) (III/StG 2) of JU 87's remained active as a Schlachtgruppe for day operations at the end of 1944.50 The JU 87's were transferred to Nachtschlachtgeschwader (night close-air-support units). ${ }^{51}$ These aircraft, however, were not numerous enough to stem major Soviet offensive operations. Thus, German anti-tank support during the Soviet Belorussian campaign was weak. 
SOVIET AIR FORCE OBJECTIVES IN THE BELORUSSIAN CAMPAIGN AND COMPARISON OF GERMAN AND SOVIET SORTIE RATES

The Soviet Air Force in the Belorussian operation employed mass to overwhelm ground and air defenses. Five air armies (1st, 3rd, 4th, 6th and 16th) deployed a total of 5,683 operational aircraft or $64.6 \%$ of all frontal aircraft. 52 An additional 1000 bombers were deployed from the Long Range Air Arm known as ADD (Aviatsiya dal'nevo deistviya) which brought the total to 6,683 or $49.8 \%$ of all Soviet operational aircraft for the support of the the Soviet summer offensive. 53

The Soviet Air Force was assigned the following tasks: firmly retain air superiority; (2) support the ground forces during the breakthrough; (3) encirclement and destruction of the enemy units at Vitebsk and Bobruisk; (4) encirclement and destruction of Army Group Center west of Minsk; (5) interdiction of enemy movement of reserves; (6) disorganize the westward retreat of German units; and (7) provide continuous aerial reconnaissance.54 The skill of VVS commanders and planning was marked by maneuvering and redeployment of air strength along the entire front to achieve the desired concentrations of air power at the moment of critical offensive operations. This support was achieved along the front and in depth.55

In May and June 1944, the Luftwaffe was capable of 1000 sorties per day. 56 However, the fuel situation (see Figure 25) and 
the increased Soviet air superiority reduced the number of sorties by the Luftwaffe on the Eastern Front. On September 11, 1944, only 250 German sorties were flown against a Soviet sortie rate of 2,000-2,500.57 The Soviet Air Force sortie rate revealed overwhelming Soviet air power compared to the German sortie rate. The Soviet Air Force flew 153,545 sorties between June 22, 1944 and August 29, 1944 which was an average of more than 2,250 sorties daily. 58 This Soviet effort was unmatched in any other wartime operation.59 Thus, Soviet air superiority was firmly established with the onset of the Soviet summer offensive.

\section{COMPARISON OF EASTERN AND WESTERN FRONTS}

The air war in the Soviet Union while significant to the outcome of the war in the East was overshadowed by the AngloAmerican air war in the West where $53.5 \%$ of the Luftwaffe was concentrated. 60 The Luftwaffe total losses and damaged aircraft for the period of June to October 1944 demonstrate the effectiveness of the Anglo-American air war. Table VI delineates the German losses by front. The defense of the Reich involved $36.9 \%$ of all losses during this period. The defense of Western and Northern Europe accounted for $31.7 \%$ of Luftwaffe losses. The Italian and Balkan Theater involved only $6.8 \%$ of total air losses.

The total Luftwaffe losses inflicted by Anglo-American forces during the period of June to October 1944 amounted to 
11,182 aircraft destroyed or damaged. ${ }^{61}$ This amounted to $75.4 \%$ of all Luftwaffe losses during this period (see Table VI). The losses incurred on the German-Soviet Front amounted to 3,650 aircraft or $24.6 \%$ of total Luftwaffe losses for the same period (see Table VI). Therefore, Anglo-American efforts can be credited with assisting the Soviet Union in achieving air superiority on the Eastern Front.

The success of the Soviet summer offensive caused a readjustment of German Luftflotten on the Eastern Front as the Wehrmacht fell back into Eastern Europe. The Luftflotten were consolidated into three Luftflotten: Lufflotte $I$ isolated in Couriand; Luftflotte II covering East Prussia to Slovakia; and Luftflotte IV defending Austria, Hungary and northern Yugoslavia. 
TABLE ॥

LUFTWAFFE AIRCRAFT DISTRIBUTION BY FRONT, AUGUST 1943

FRONT

German-Soviet Front:

Western European Front:

Italian Front:

Balkan Front:

Norwegian Area:

Reich Air Defense:

Totals:
AIRCRAFT

2,896

744

841

451

203

1,498

6.633
PERCENT

$43.6 \%$

$11.3 \%$

$12.7 \%$

$6.8 \%$

$3.0 \%$

$\underline{22.6 \%}$

$100.0 \%$

Source: Olaf Groehler, "Staerke, Verteilung und Verluste der deutschen Luftwaffe im Zweiten Weltkrieg," Militaer Geschichte No. 3, 1978, p. 328.

TABLE III

LUFTWAFFE AIRCRAFT DISTRIBUTION BY FRONT, JUNE 1944

\section{FRONT}

German-Soviet Front:

Western European Front:

Italian Front:

Balkan Front:

Norwegian Area:

Reich Air Defense:

Totals:
AIRCRAFT

3,267

1,450

353

567

204

1.572

7,413
PERCENT

$44.0 \%$

$19.6 \%$

$4.8 \%$

$7.7 \%$

$2.7 \%$

$\underline{21.2 \%}$

$100.0 \%$

Source: Olaf Groehler, "Staerke, Verteilung und Verluste der deutschen Luftwaffe im Zweiten Weltkrieg," Militaer Geschichte No. 3, 1978, p. 328. 


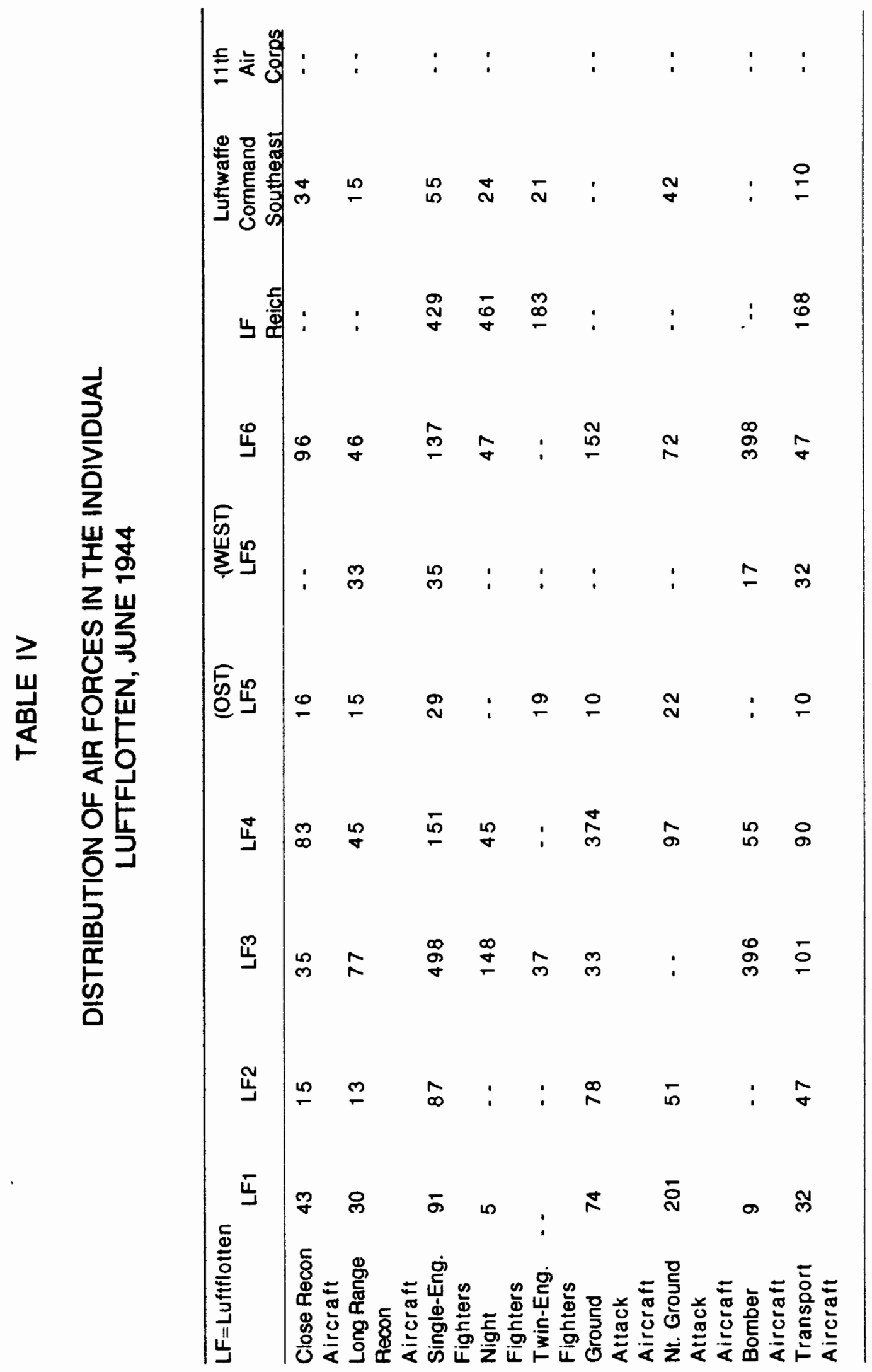




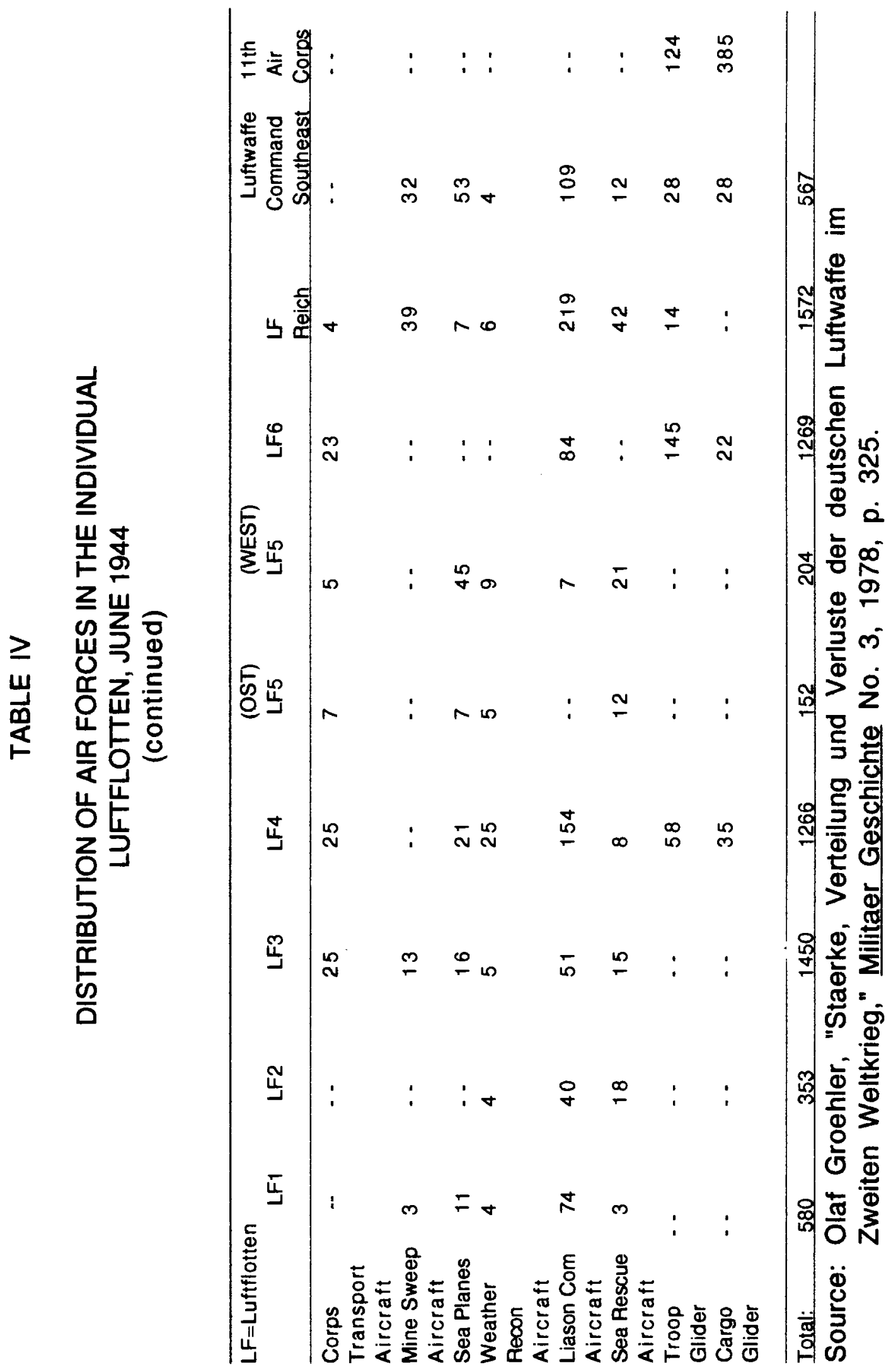




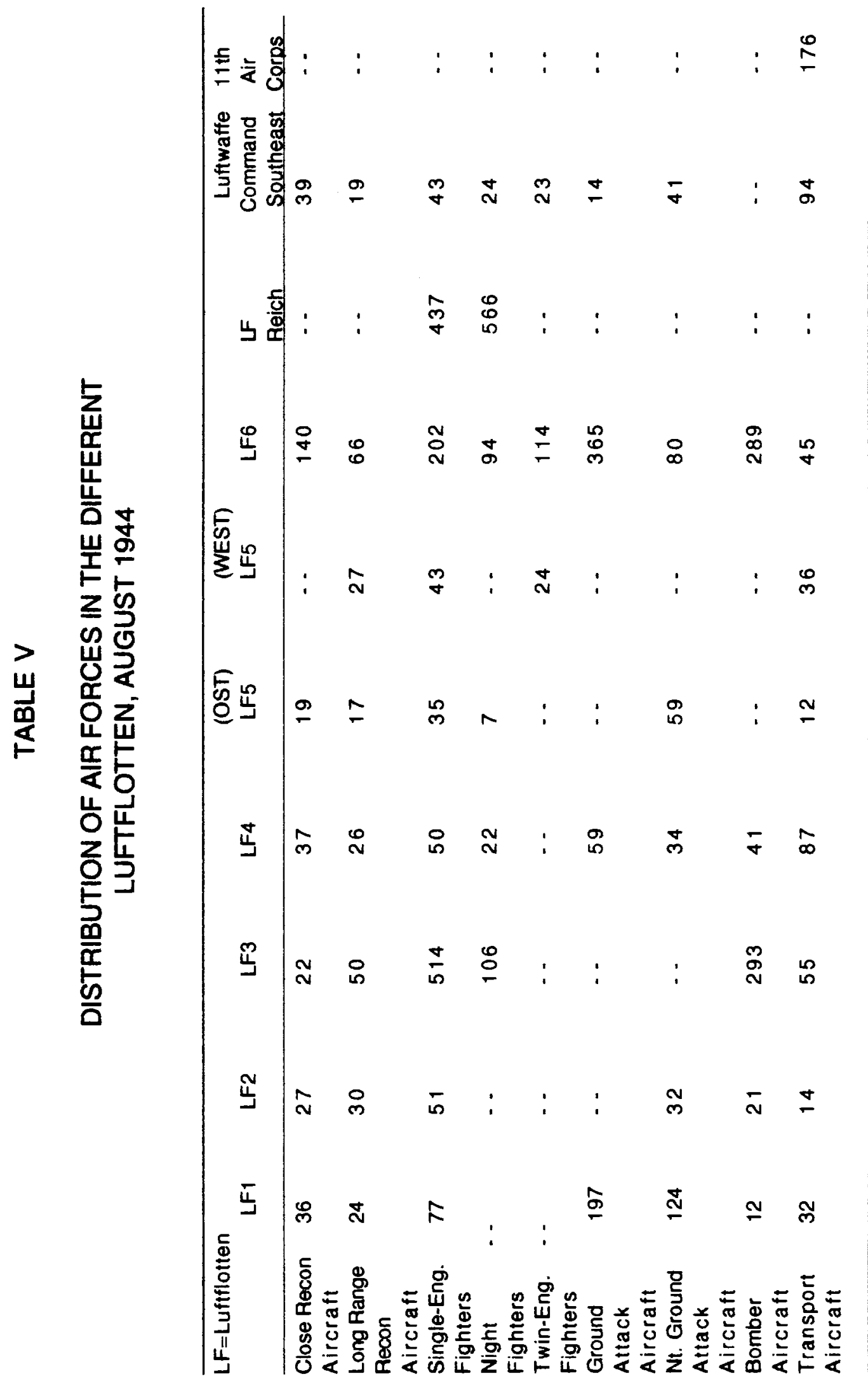




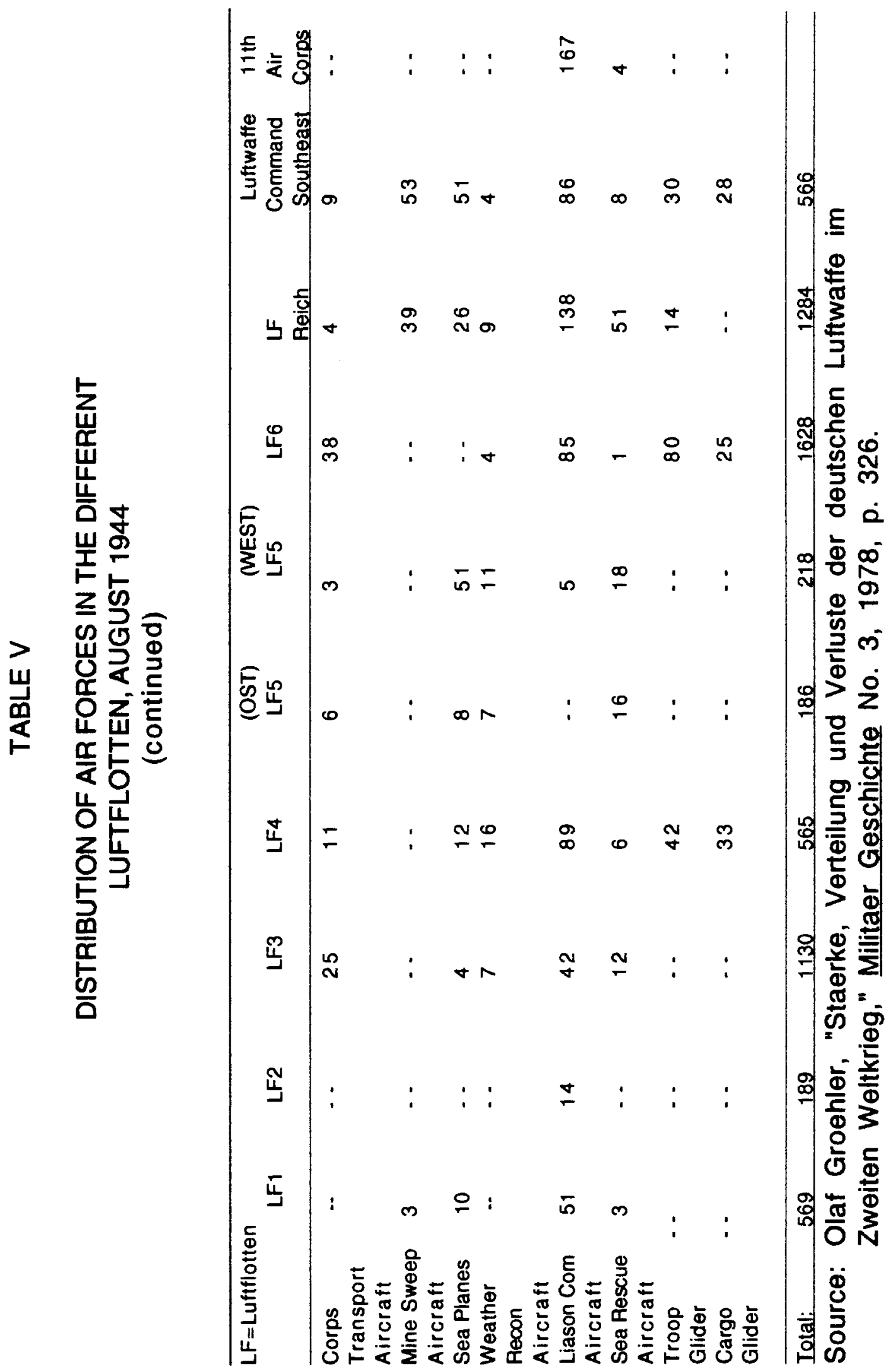




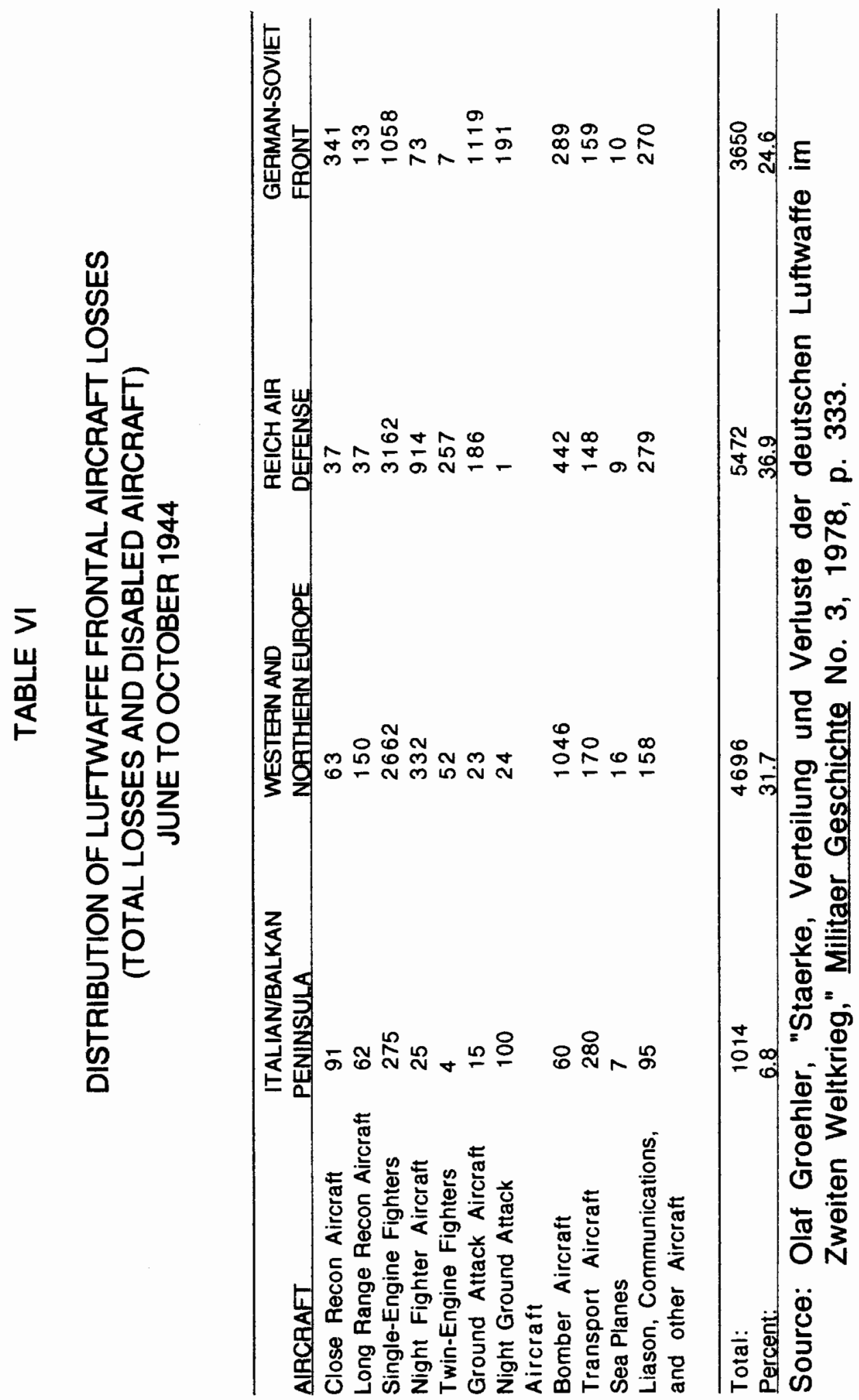




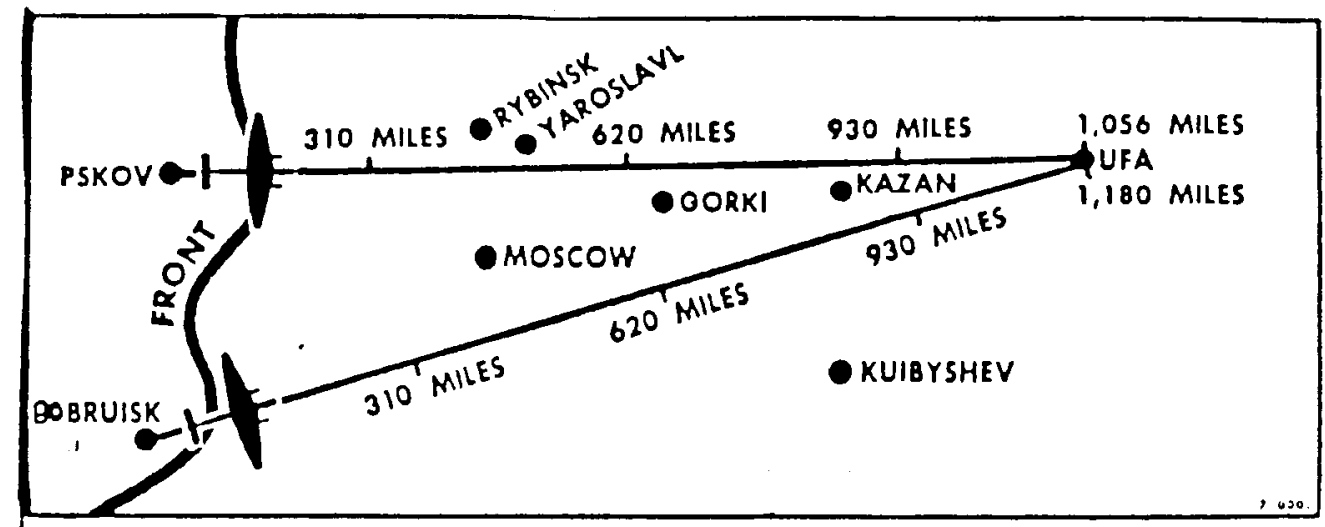

Figure 16. Soviet Production Centers. Source: General Hans-Detluf Herhudt von Rhoden, "The Last Great Attack of the German Bombers in the Eastern Theater of Operations," Military Review Vol. 31, September 1951, p. 74. 


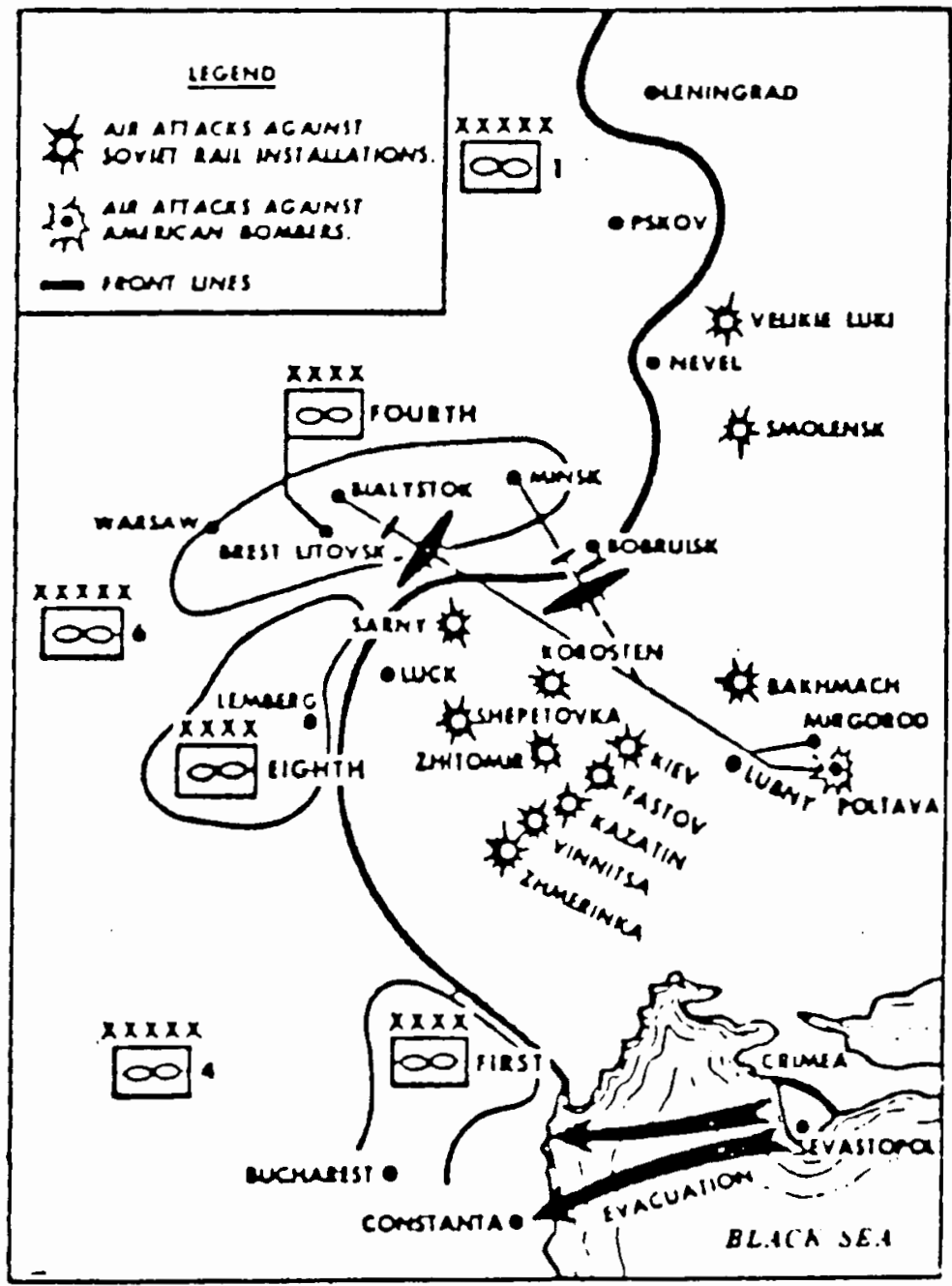

Figure 17. The Luftwaffe's Last Strategic Victory in the East. Source: General Hans-Detluf Herhudt von Rhoden, "The Last Great Attack of the German Bombers in the Eastern Theater of Operations," Military Review Vol. 31, September 1951, p. 76. 


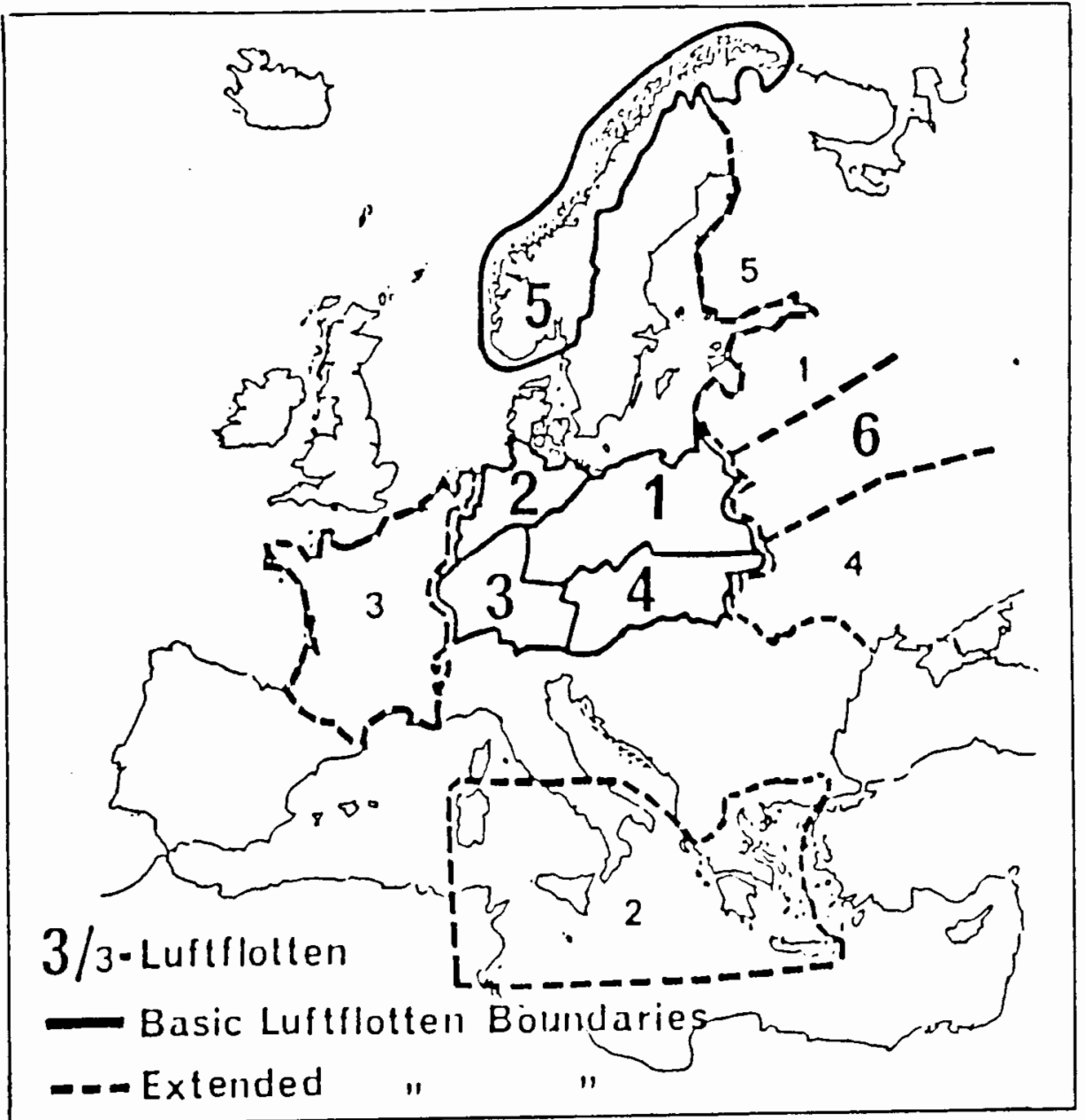

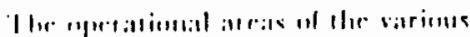

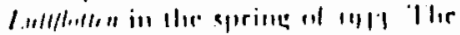

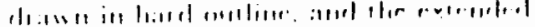

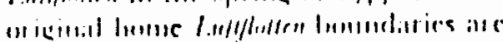

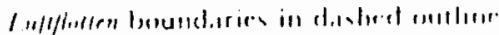

Figure 18. Luftflotten Boundaries. Source: Alfred Price, Luftwaffe Handbook 1939-1945 (New York: Charles Scribner's Son, 1977), p. 11. 
TAKTISCHE UNTERSTELLUMGSVERHALTMISSE IN DER DEUTSCHEN LUFTHAFFE

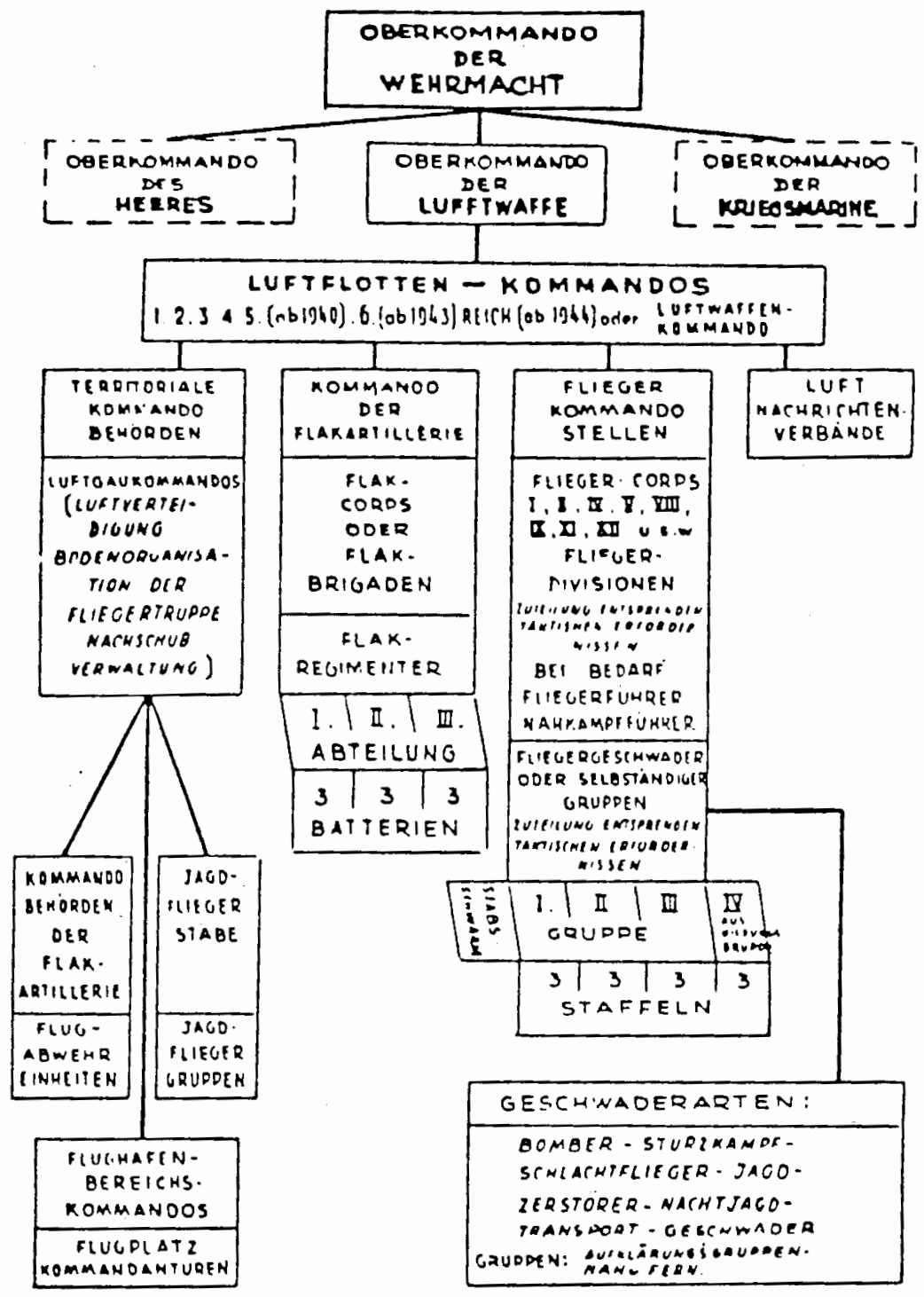

Figure 19. Tactical Subordinate Relationships in the German Air Force. Source: General der Flieger a. D. Paul Deichmann, German Air Force Operations in Support of the Army, USAF Historical Studies: No. 163 (New York: Arno Press, 1963), p. 207. 


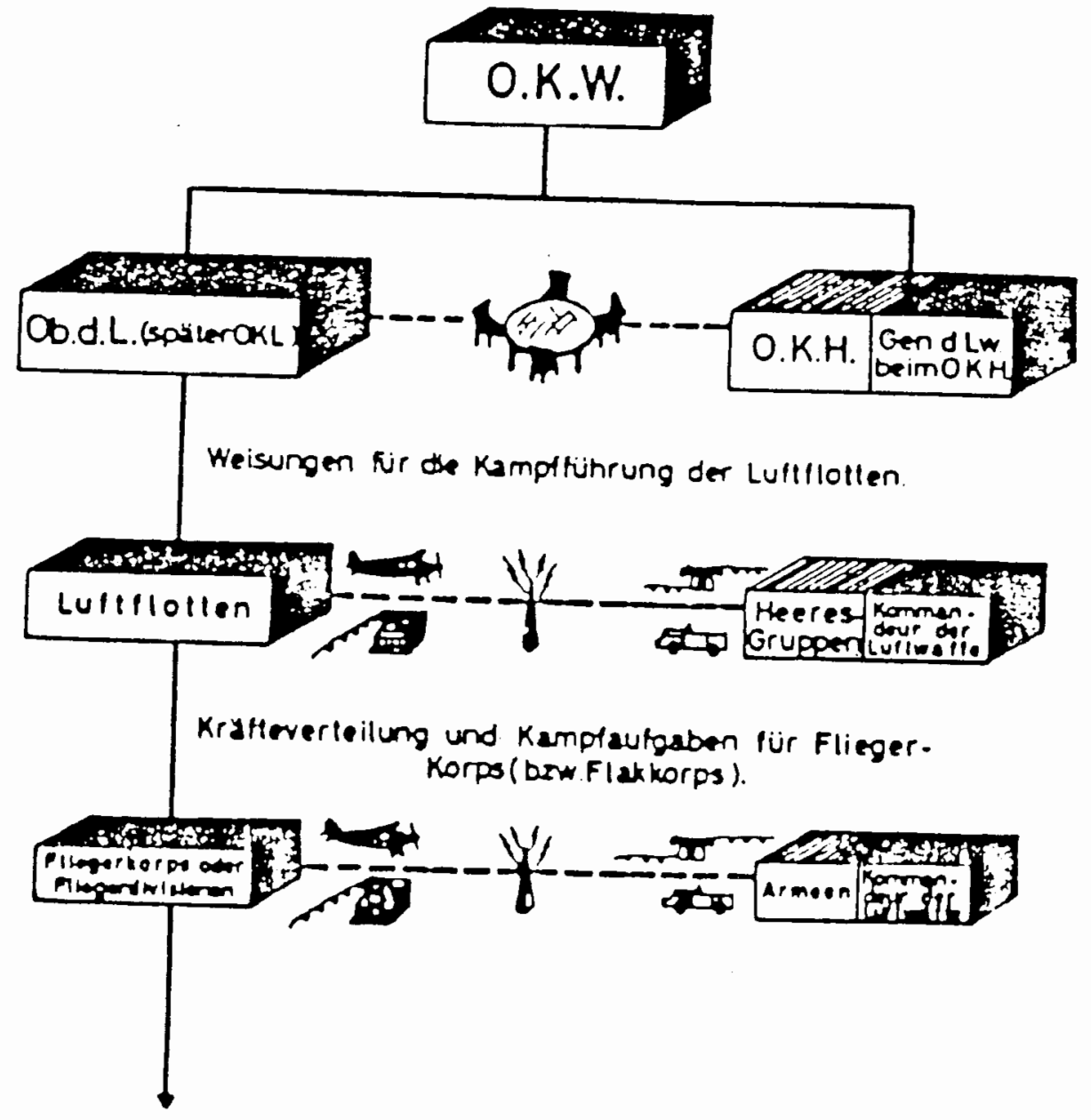

Figure 20. Command Organization and Chain of Command for Operations of Flying Units in Support of the Army by Interdiction of the Battlefield. Source: General der Flieger a. D. Paul Deichmann, German Air Force Operations in Support of the Army, USAF Historical Studies: No. 163 (New York: Arno Press, 1963), p. 188. 


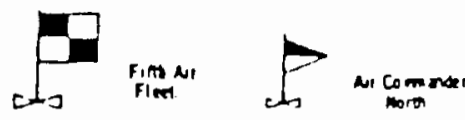

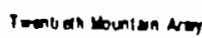

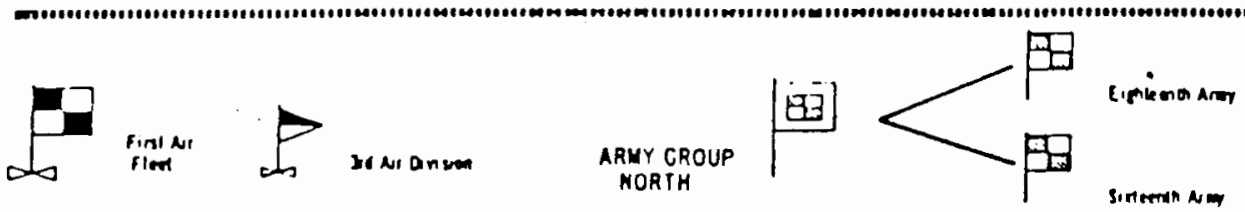

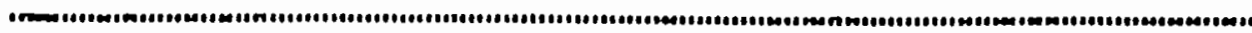
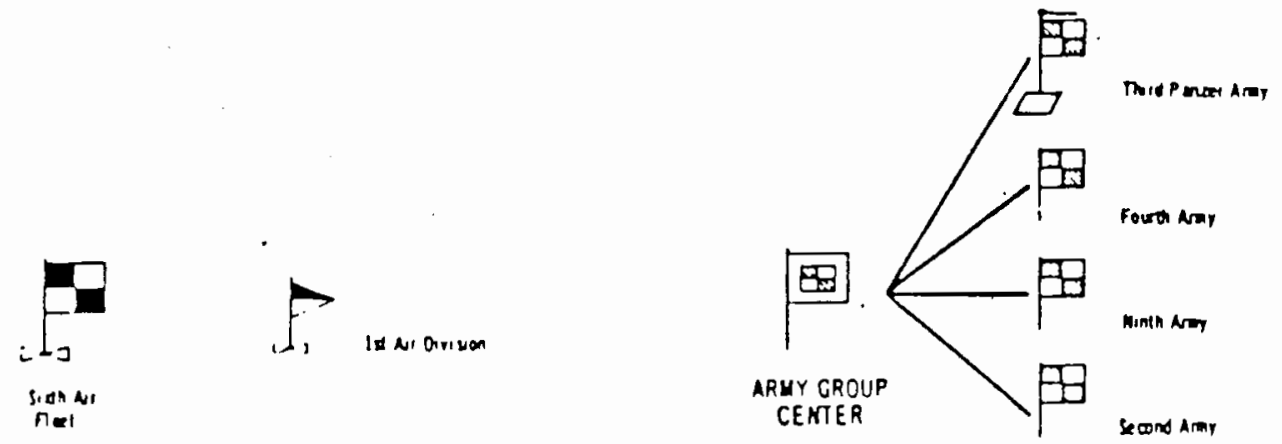

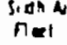

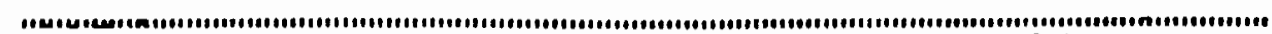
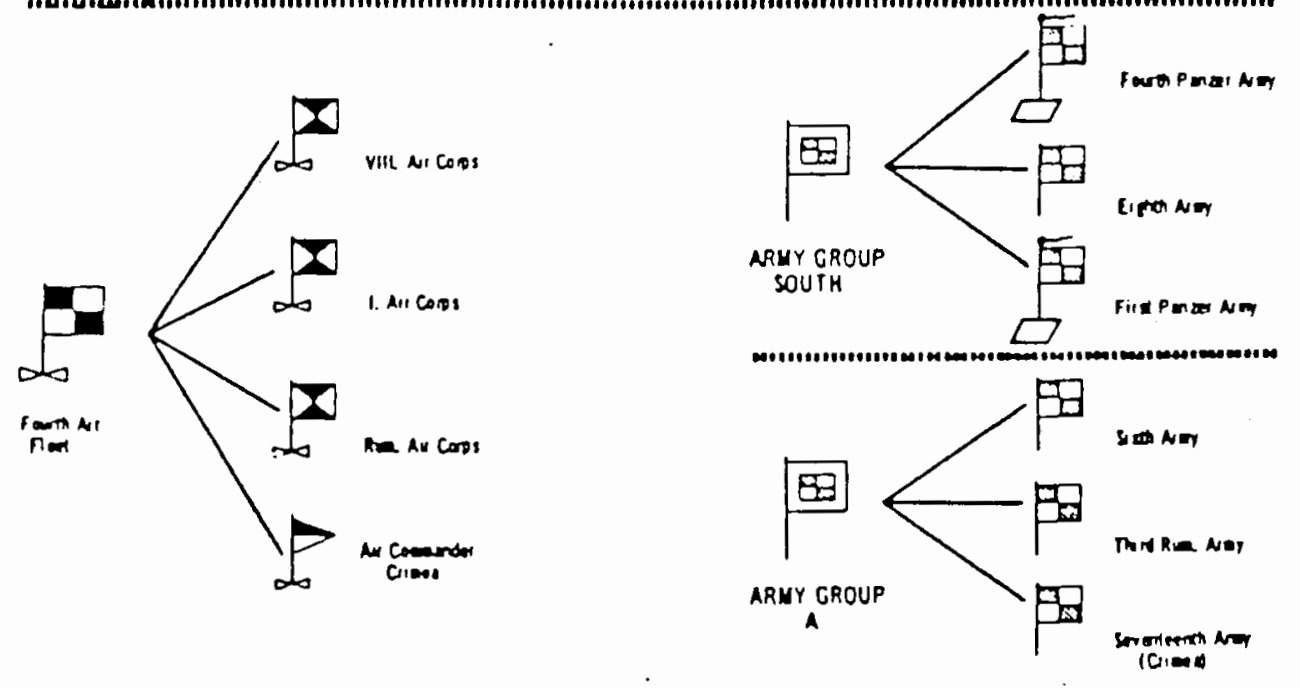

Figure 21. Command Relationships Between Luftwaffe And Army On The Eastern Front, 25 December 1943. Source: Generalleutnant Hermann Plocher, The German Air Force Versus Russia, 1943, USAF Historical Studies: No. 155, (New York: Arno Press, Inc., 1968), p. 364. 


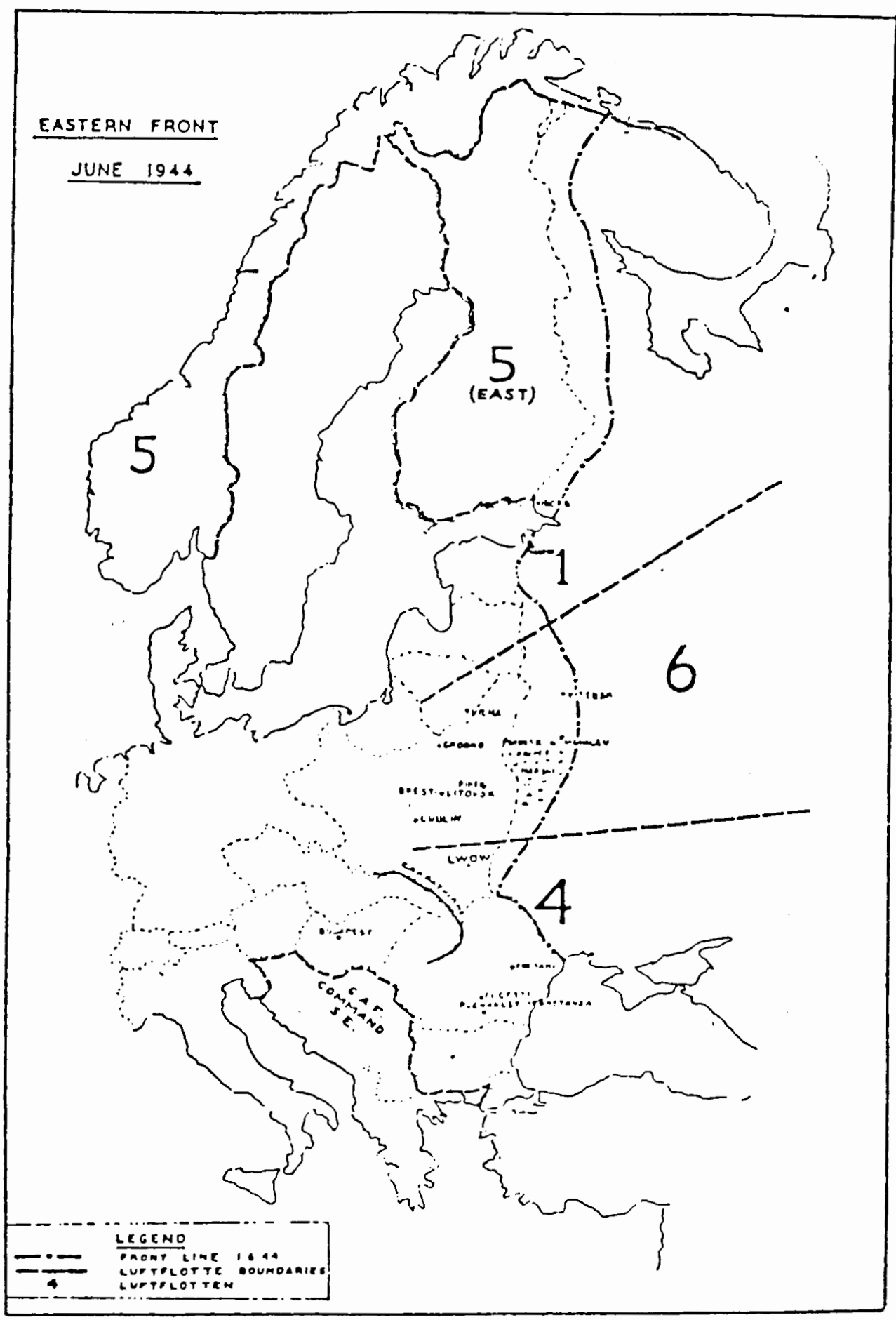

Figure 22. Luftflotten Eastern Front, June 1944. Source: Royal Air Force, Air Historical Branch, The Rise and Fall of the German Air Force 1933-1945 (New York: St. Martins Press, 1983), p. 360. 


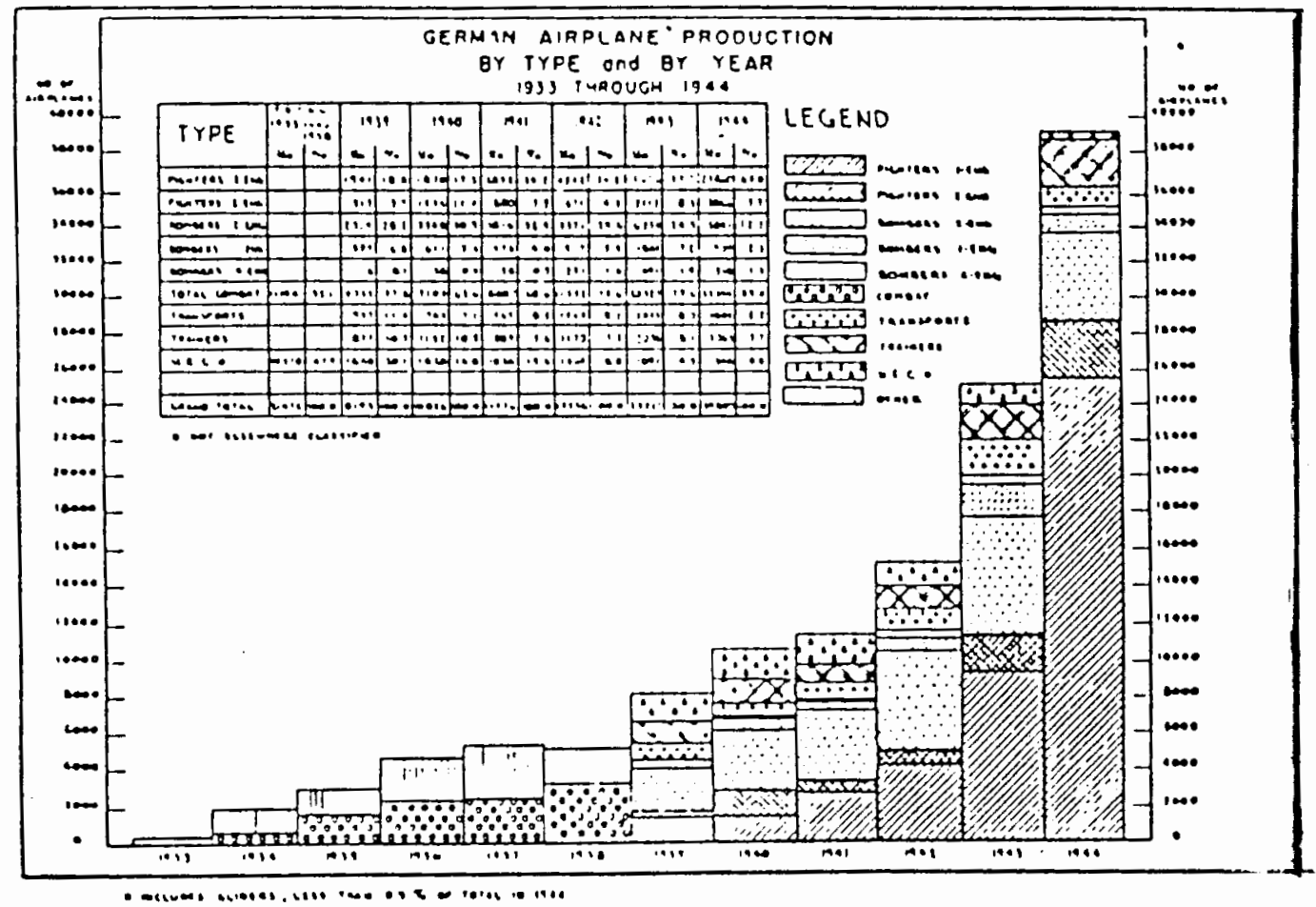

Figure 23. German Airplane Production By Type And By Year, 1933-1944. Source: The United States.Strategic Bombing Survey, Aircraft Division Industry Report, Aircraft Division, January 1947, Figure VI-I. 
NUMBER OF GERMAN AIRCRAFT PRODUCED BY .TYPES AKMUALLY $1939 \cdot 44$

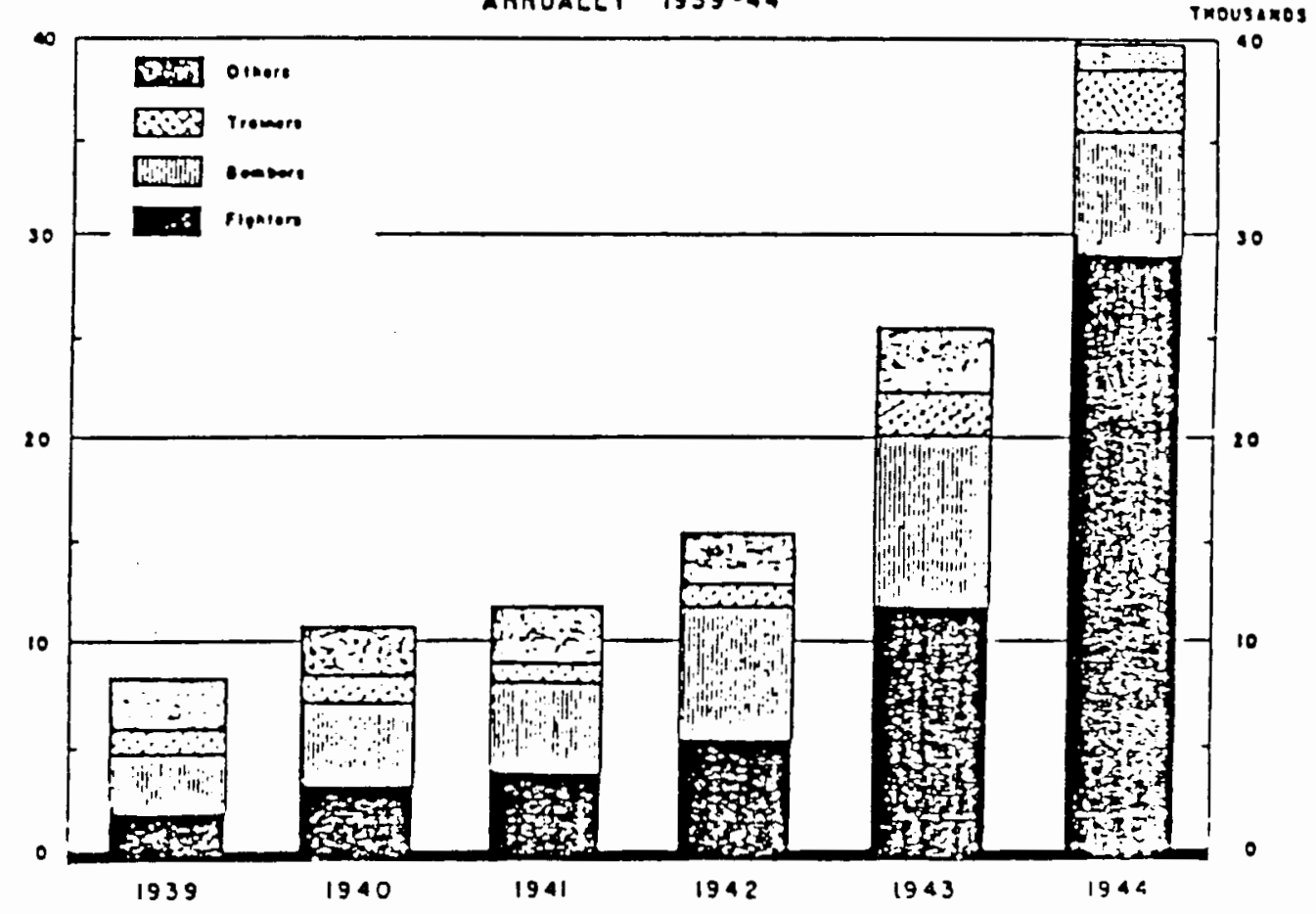

Figure 24. Number of German Aircraft Produced by Types, 1939-44. Source: The United States.Strategic Bombing Survey, Aircraft Industry Report, Aircraft Division, January 1947, Exhibit D-4. 


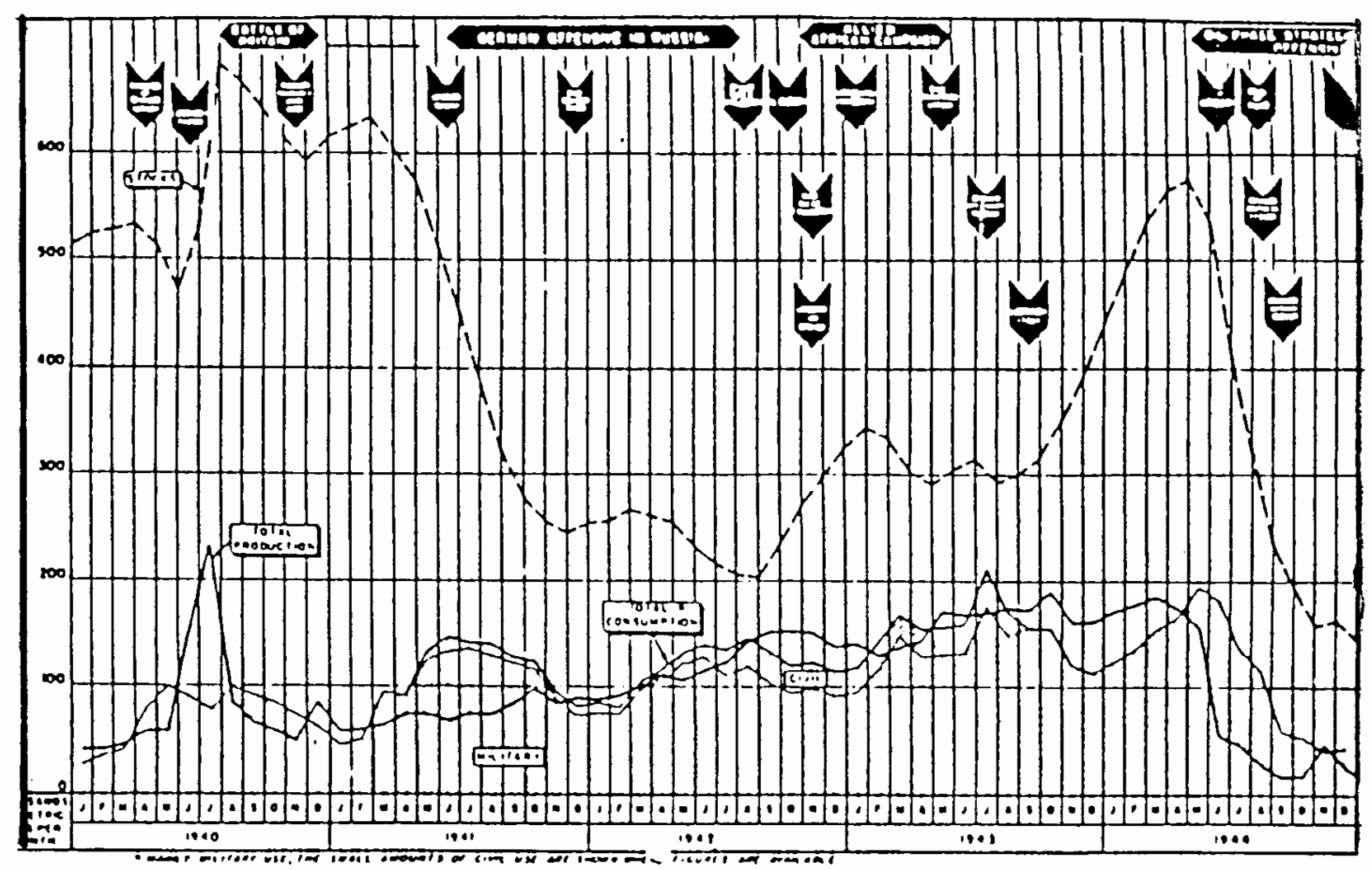

Figure 25. Aviation Gasoline Production, Consumption and Stocks, January 1940-April 1945. Source: The United States.Strategic Bombing Survey, Oil Division Final Report, Oil Division, January 1947, Figure 22. 
Einsatz der IV.Pz./S.G.9

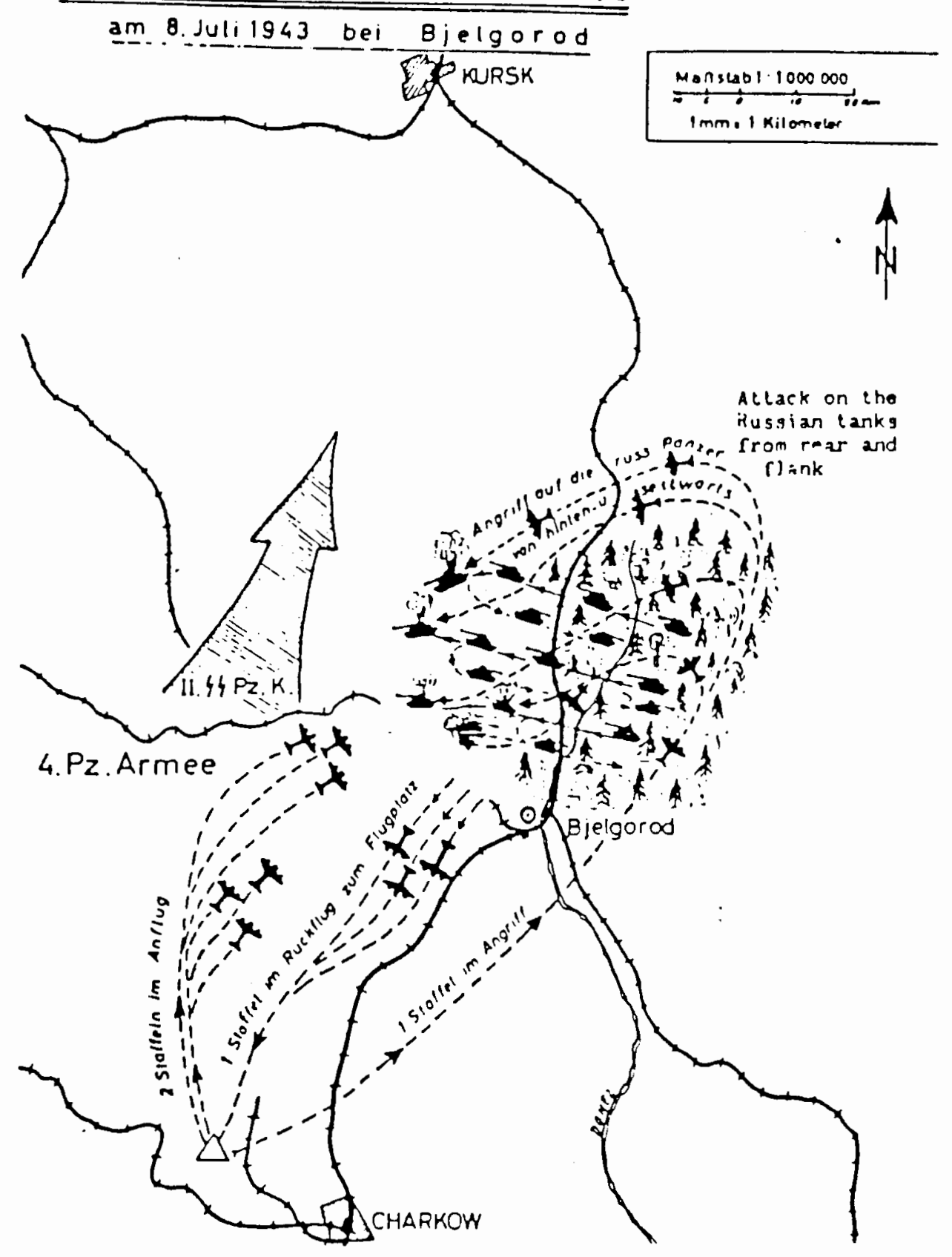

Figure 26. Operation of IV Panzer and 9th Ground Attack Wing on July 8, 1943 at Bjelgorod. Source: General der Flieger a. D. Paul Deichmann, German Air Force Operations in Support of the Army, USAF Historical Studies: No. 163 (New York: Arno Press, 1963), p. 202. 


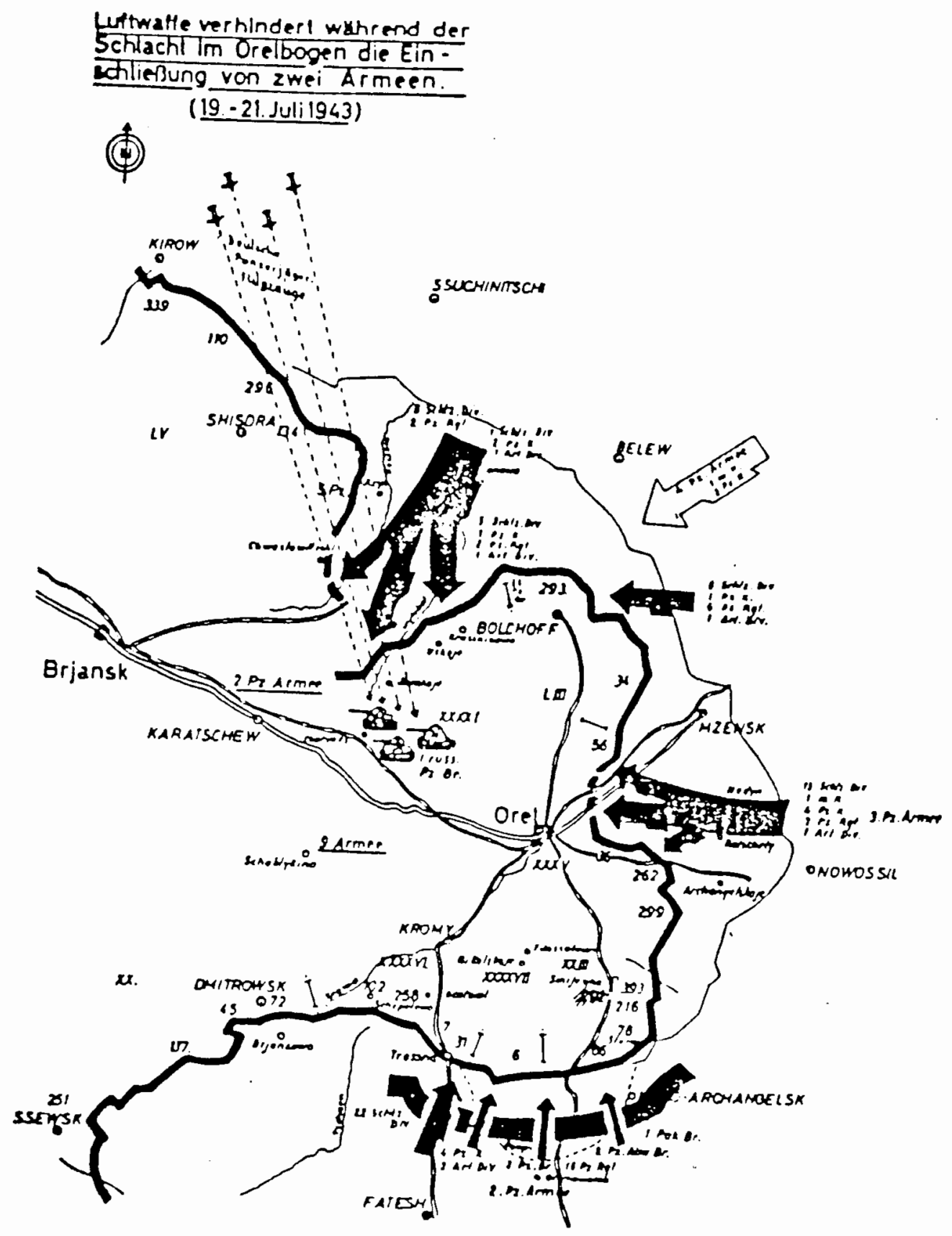

Figure 27. Luftwaffe Prevents The Union Of Two Armies During The Battle Of Orel Bend. Source: General der Flieger a. D. Paul Deichmann, German Air Force Operations in Support of the Army, USAF Historical Studies: No. 163 (New York: Arno Press, 1963), p. 201. 


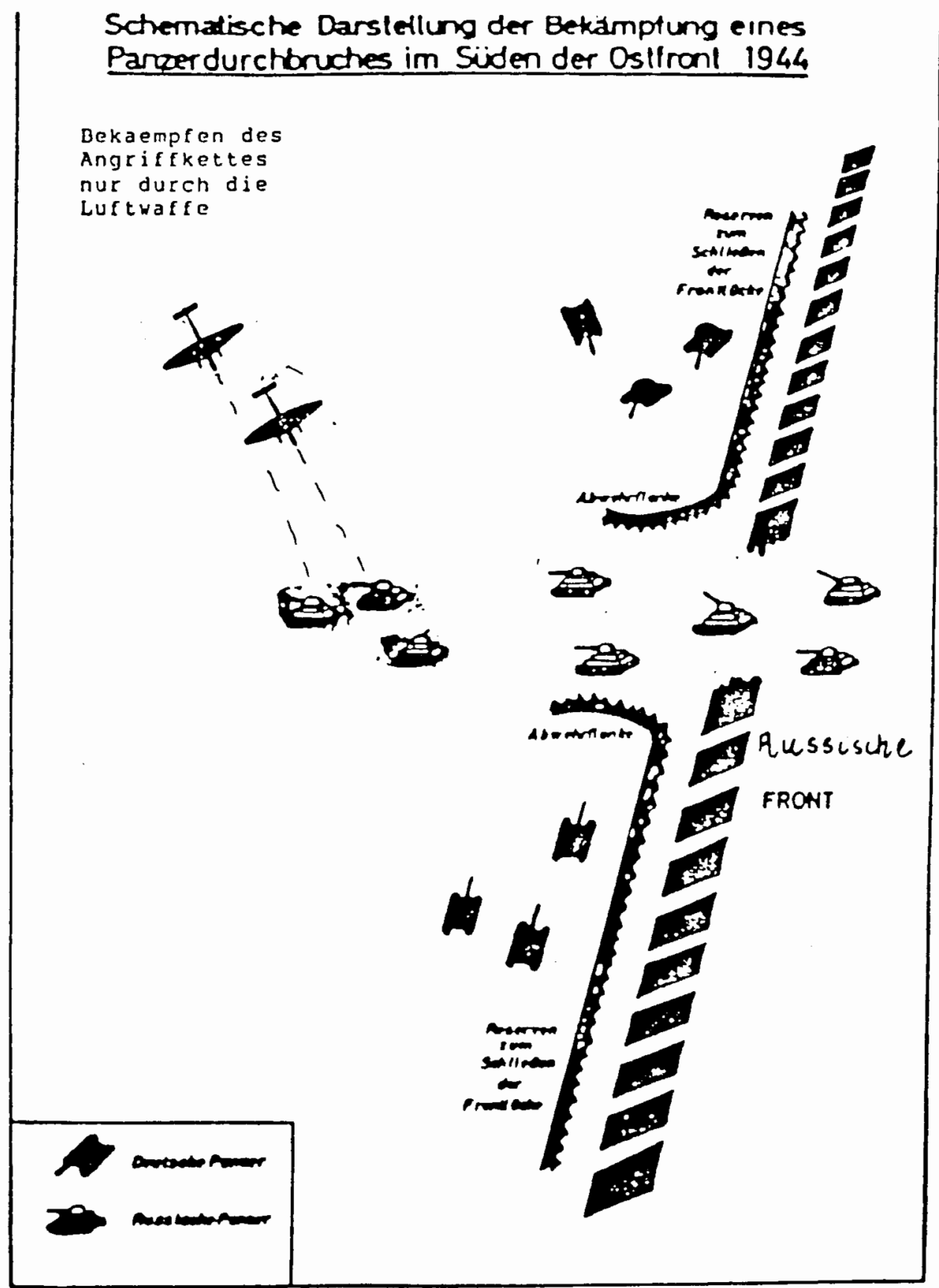

Figure 28. Schematic Presentation Of Control Of An Armored Breakthrough On The Eastern Front, South, 1944. Source: General der Flieger a. D. Paul Deichmann, German Air Force Operations in Support of the Army, USAF Historical Studies: No. 163 (New York: Arno Press, 1963), p. 204. 


\section{NOTES TO CHAPTER IV}

${ }^{1}$ Generalleutnant Hermann Plocher, The German Air Force Versus Russia. 1943, USAF Historical Studies: No. 155 (New York: Arno Press, 1968), p. 281.

2Ibid., p. 274.

${ }^{3}$ General der Flieger a. D. Paul Deichmann, German Air Force Operations in Support of the Army, USAF Historical Studies: No. 163 (New York: Arno Press, 1963), p. 165.

4 Ibid.

${ }^{5}$ Richard Suchenwirth, Historical Turning Points in the German Air Force War Effort, USAF Historical Studies: No. 189 (New York: Arno Press, 1963), p. 77.

Glbid., p. 76.

7 lbid.

8lbid.

${ }^{9}$ Royal Air Force Air Historical Branch, The Rise and Fall of the German Air Force 1933-1945 (New York: St. Martins Press, 1983), p. 240.

10 lbid.

${ }^{11}$ Lonnie O. Rately III, "A Comparison of the USAF Projected A-10 Employment in Europe and the Luftwaffe Schlachtgeschwader Experience on the Eastern Front in World War Two," (Master's Thesis, Naval Postgraduate School, California, March 1977 , p. 159.

12 Suchenwirth, pp. 88-89.

13Matthew Cooper, The German Air Force 1933-1945: An Anatomy of Failure (New York: Jane's Publishing Inc., 1981), p. 328.

${ }^{14}$ Royal Air Force Historical Branch, p. 243.

15Ibid., p. 240.

16 Ibid.

17 Suchenwirth, p. 90.

18/bid., p. 90. 
19Deichmann, p. 169.

${ }^{20}$ General Hans-Detlef Herhudt von Rhoden, "The Last Great Attack of the German Bombers in the Eastern Theater of Operations," Military Review Vol. 31, September 1951, p. 74.

21 lbid.

22Deichmann, pp. 165-166.

23ibid., p. 169.

${ }^{24}$ General Hans-Detlef Herhudt von Rhoden, p. 74.

25Ibid., p. 76.

26 lbid., p. 77.

27Deichmann, p. 171.

${ }^{28}$ Alexander Boyd, The Soviet Air Force Since 1918 (New York: Stein And Day Publishers, 1977), p. 153.

${ }^{29}$ Ibid., p. 185.

30Olaf Groehler, "Staerke, Verteilung und Verluste der Deutschen Luftwatfe im Zweiten Weltkrieg," Militaer Geschichte No. 3, 1978, p. 328.

31/bid.

32ibid.

${ }^{33}$ Royal Air Force Air Historical Branch, p. 358.

34lbid., p. 243.

35 bid., p. 358.

${ }^{36}$ Groehler, p. 268.

37Generalleutnant a. D. Walter Schwabedissen, The Russian Air Force in the Eyes of German Commanders, USAF Historical Studies: No. 175 (New York: Arno Press, 1960), p. 267.

$38 \mathrm{lbid}$.

39 lbid. 
40/bid., p. 268.

${ }^{41}$ Robin Higham and Jacob W. Kipp, Soviet Aviation and Air Power (Boulder, Colorado: Westview Press Inc., 1977), p. 114.

42Ibid., pp. 114-115.

43 lbid., p. 115.

${ }^{44}$ Paul J. Murphy, The Soviet Air Forces (Jefferson, North Carolina: Mcfarland \& Company Inc., 1984), p. 54.

45Alfred Price, Luftwatfe Handbook 1939-1945 (New York: Charles Scribner's Sons, 1977), pp. 43-45.

46Ibid., p. 43.

${ }^{47}$ Captain Lonnie O. Ratley III, "A Lesson for Today? Air Power at Kursk," Military Review Vol. 58, April 1978, pp. 58-60; Major William J. Dalecky, "Battlefield Air Interdiction by the Luftwaffe at the Battle of Kursk-1943," (Master's thesis, U.S. Army Command and General Staff College, Fort Leavenworth, Kansas, 1980), pp. 31-36; Paul Carell, Scorched Earth (London: George G. Harrap \& Co. LTD, 1970), pp. 75-76; Joseph E. Thach Jr., "The Battle of Kursk, July 1943: Decisive Turning Point on the Eastern Front," (PH.D Dissertation, Georgetown University. Washington D.C., 1971), pp. 306-329.

48Price, pp. 43-45.

49 lbid., p. 45.

50Lonnie O. Rately III, A Comparison of the USAF Projected A-10 Employment in Europe and Luftwaffe Schlachtgeschwader Experience on the Eastern Front in World War Two, p. 41.

51 Ibid.

52Murphy, p. 63.

53|bid., p. 62.

54Oleg Hoeffding, Soviet Interdiction Operations, 1941-1945, United States Air Force Project Rand Report, (Santa Monica, California: Rand Corporation, 1970), p. 16.

55Murphy, p. 63. 
${ }^{56}$ Von Hardesty, Red Phoenix (Washington D.C.: Smithsonian Institution Press, 1982), p. 181 .

${ }^{57}$ Royal Air Force Air Historical Branch, p. 362.

58Higham \& Kipp, p. 117.

59 lbid.

60 Groehler, p. 328.

61 Ibid., p. 333. 


\section{CHAPTER V}

\section{LEND-LEASE AND ITS IMPACT ON THE COLLAPSE OF THE WEHRMACHT IN THE EAST IN THE SUMMER OF \\ 1944}

Lend-Lease contributed greatly to the military success of the Red Army in 1944. Lend-Lease supplies which the Soviet Union had received in 1941 and 1942 had not contributed significantly to the military successes of the Soviet Union. However, Lend-Lease supplies that reached the Soviet Union in 1943 and 1944 were significant to Soviet military success and consequently the collapse of the German Army in the East in the summer of 1944.

Soviet writers fail to credit Lend-Lease with helping the Soviets achieve military victory over the Germans. They contend that Lend-Lease amounted to only 4 percent of Soviet industrial production although the proportion of western tanks is credited with 7 percent and 13 percent of aircraft. 1 Soviet writers take the position that "deliveries of this size could not have possibly had any marked effect on the course of the war," and Lend-Lease was "an insignificant supplementary source" of supplies. ${ }^{2}$ The supplies received after Stalingrad were "no longer needed," but during the critical first 6 months of the war Lend-Lease supplies amounted to only 0.1 percent of total Soviet production. ${ }^{3}$ 
Despite Soviet disclaimers about Lend-Lease aid, the importance of this aid can be readily established in the years 1943-1945. Lend-Lease aid was supplied by several routes (see Figure 29). The Northern Russia convoy route was the most dangerous and difficult (see Figure 30). The opening of the "Persian corridor, facilitated the delivery of Lend-Lease supplies (see Figure 31). In 1943, shipments through the "Persian corridor" included 920 tanks, more than 5000 aircraft, and almost 145,000 motor vehicles or nearly five times more than in 1942.4 The Soviet Union had received 173,000 vehicles and 4,300 tanks from the United States by the end of 1943.5 The gross tonnage had almost doubled and reached the level of 27 percent of all U.S. Lend-Lease (see Table VII).

According to Table VII, 63 percent of all Lend-Lease arrived during 1943 and 1944. In the last 14 months of the war the Soviets received almost 11.1 million tons of Lend-Lease supplies. 6 The Lend-Lease shipments of 1944 were approximately 30 percent greater than in 1943.7 However, the dollar value of the Lend-Lease supplies received during the twelve months ending in June 1944 exceeded the previous 12 months by 81 percent (see Table VIII \& IX). ${ }^{8}$ This level of assistance can be seen to have contributed to Soviet military power when the types of supplies are examined.

There are various opinions as to which Lend-Lease supplies contributed most to Soviet victory. The United States supplied the U.S.S.R. with $15,000,000$ pairs of boots between March 1941 to October 1945.9 The U.S.S.R. received 6 million pairs of boots by 
1944.10 Therefore, the Red Army marched in boots primarily provided by the United States and boots were essential to the mobility of Red Army infantry. Food has been ranked as also important. American Lend-Lease food could have provided one pound of concentrated ration per day for 6 million soldiers for the length of the entire war. ${ }^{11}$ Lend-Lease food prevented a substantial reduction in civilian food supplies. It has been estimated that average civilian caloric consumption would have declined by at least one-third without Lend-Lease. ${ }^{12}$ According to Secretary of State, Edward R. Stettinius, Jr. in 1944:

The best-fed group in Russia today is the Red Army. Everything has been sacrificed for the soldiers, and Lend-Lease food shipments have helped to keep their fighting strength high. ${ }^{13}$

Furthermore, Stettinius declared in 1944:

Planes and tanks are the most dramatic part of our Lend-Lease aid to Russia, but in the last analysis they are probably not the most important. As Admiral Akulin said soon after he arrived in this country, "by sending us raw materials and manufacturing equipment, you actually increase the combat strength of the Red Army considerably more than you do by the number of planes and tanks you send us." 14

\section{LEND-LEASE AIRCRAFT IN THE SOVIET UNION}

It is evident that Lend-Lease supplies assisted the Soviets in numerous areas. However, in the summer of 1944 the Red Army 
required mobility and air power to defeat the German Army in the East. Lend-Lease made significant contributions in both of these areas. Lend-Lease aircraft comprised about 15 percent of the Soviet Air Force in 1943.15 The Soviet Union had received 6,430 aircraft from the United States and 5,800 aircraft from Britain between June 22, 1941 and April 30, 1944.16 By October of 1944, Lend-Lease aircraft amounted to 8,734 U.S. and 6,015 British aircraft. 17 Soviet combat losses amounted to 1,500 per month or 18,000 aircraft per year. ${ }^{18}$ According to Table $X$ most of the U.S. Lend-Lease aircraft that arrived between June 22, 1941 and October 1944 were delivered after July 31, 1943. Therefore, between August 1943 and October 1944 the Soviet Union received 5,087 U.S. Lend-Lease aircraft or 58 percent of all U.S. aircraft deliveries made since June 22, 1941. The increased deliveries of . aircraft assisted the Soviet Union in replacing its combat losses of 1,500 aircraft per month and in establishing air superiority in 1944.

\section{THE IMPACT OF LEND-LEASE MOTOR VEHICLES IN THE SOVIET UNION}

The most significant impact of Lend-Lease on the collapse of the German Wehrmacht in the East was the delivery of motor vehicles to the Soviet Union which made it possible to motorize the Red Army. Table XI delineates in detail the number of vehicles delivered to the Soviet Union. Analysis of certain vehicle 
categories shows how important Lend-Lease was to the motorization of the Red Army. The following vehicle categories are summarized based upon the actual vehicles which arrived in the Soviet Union from U.S. Lend-Lease:

$\begin{array}{ll}\text { Jeeps } & 47,238 \\ \text { Trucks } & 362,288 \\ \text { Ordnance Service Vehicles } & 2,293 \\ \text { Light Tanks } & 1,239 \\ \text { Medium Tanks } & 4,957 \\ \text { Self-Propelled Guns } & 1,807 \\ \text { Half-Tracks } & 1,104 \\ \text { Armored Scout Cars } & 3,054 \\ \text { Motorcycles } & 32,200 \\ \text { Locomotives } & 1,966 \\ \text { Railway Cars } & 11,075\end{array}$

The vehicle totals given above represent the total U.S. Lend-Lease arrivals in the Soviet Union for the entire war. But most of the motor vehicles had reached the Soviet Union by the end of the Third Protocol period on June 30,1944 . Table XII shows the distribution of tonnage for trucks, other vehicles and railroad transportation equipment as shipped by period and protocol.

Railroad equipment played only a minor role since only 70,466 tons or 15 percent of Lend-Lease railroad equipment was shipped between July 1, 1943 and June 30, 1944. No other railroad equipment had been furnished prior to the third protocol period.

The analysis of motor vehicle tonnage revealed that a total tonnage of $1,406,564$ tons was shipped to the Soviet Union by June 30,1944 . This constituted 61 percent of all motor vehicle tonnage shipped to the Soviet Union. A total of 883,387 tons or 39 percent 
was received after June 30,1944 and of this amount 238,117 tons or 10.4 percent was received after Germany had surrendered.

Approximately 61 percent of all Lend-Lease vehicles were furnished to the Soviet Union before July 1, 1944. Between July 1, 1943 and June 30, 1944 approximately 742,337 tons or 32 percent of all Lend-Lease motor vehicles were received. The Soviet Union received 645,270 tons or 28 percent of all Lend-Lease vehicles Between July 1, 1944 and May 12, 1945. Therefore, the bulk of Lend-Lease motor vehicles were available for the Soviet summer offensive of 1944.

Lend-Lease motor vehicles "put the Red Army infantry on wheels for the first time in its history." 19 Previously, the Red Army infantry had to march into battle and during the course of offensive operations would lag behind the armored formations. The German Army would then isolate the exposed armored units and cut them off and seal the breach in their lines before the advancing Soviet infantry could reach the exposed armored units. However, with Lend-Lease trucks and vehicles the infantry could advance with the Soviet armored formations and effectuate strategic breakthroughs. According to the historian John Erickson:

In the offensive operations of 1942-3 the Red Army had been severely inhibited by the lack of lorries. Here Lend-Lease Supplies which pumped in 183,000 lorries and jeeps by mid-1943 (and a grand total of 430,000 by 1944), certainly relieved some of the Red Army's chronic lorry starvation. Every operation, both in preparation and execution, had been impeded by the 
shortage of lorries; every armored formation needed more lorries than it could muster. 20

Red Army Officers told U.S. Ambassador William Averell Harriman in the summer of 1944 that without Lend-Lease American trucks the Red Army could not have advanced so rapidly. 21 The retreating Wehrmacht had systematically destroyed railways and bridges. Therefore, the advancing Red Army was extremely dependent on motor vehicles to move their troops around and through devastated areas. According to an American official report Lend-Lease trucks carried "half of the highway-borne supplies for the advancing Soviet armies in the great offensives of this (1944) spring and summer on the Eastern Front."22 British observers noted that Lend-Lease vehicles were important to the Red Army's success. ${ }^{23}$ The British observed that the success of the Red Army artillery was dependent on transport which was primarily LendLease trucks. 24 The British believed that of all the Lend-Lease aid, "the most valuable was probably the vast number of trucks."25

U.S. Military Attache, General John R. Deane claimed that truck transportation and combat vehicles were the most important Lend-Lease items. ${ }^{26}$ On a trip to the Russian front in July 1944, General Deane noted:

We encountered American trucks everywhere. They appeared to be the only sort of vehicles used for convoy work. The roads were jammed with transportation of all descriptions, but except for American trucks there did not appear to be enough of any one kind to set up convoys which could be moved as units. They were easily recognized by the blue "U.S." and the American serial number stenciled on the hood of each... We saw 
thousands of American trucks on the road. They were the only vehicles which appeared to be organized into transportation units. Many of them carried troops... ${ }^{27}$

General Deane delineated the significance of Lend-Lease aid by comparing the Soviet and German armies:

It was apparent that the Russian victories were won by superior mobility. The combined bomber offensive of the Western Allies was taking its toll of German oil, and the German artillery and much of the transport we saw was mostly horsedrawn. The Russians with their preponderance of motorized and mechanized equipment were thus able to outmaneuver the Germans. Here again one could see the results of American assistance. 28

The large numbers of four and six wheeled American trucks enabled the Soviet tank and motorized formations to move crosscountry while the German armor and motorized units were tied to the roads because of the lack of motorization in these formations. ${ }^{29}$ Many Panzer divisions were forced to rely on horsedrawn panje columns for supply and baggage transport. ${ }^{30}$ According to historian Albert Seaton:

The German equivalent to the Red Army quarter-ton jeep for commander or messenger remained the horse. The counterpart of the Studebaker or Dodge six-wheeled drive truck was the horse-drawn panje wagon. 31

Thus, the Red Army had achieved not only numerical superiority but also a superiority in motorization and mechanization over the Wehrmacht. 
SOVIET AND GERMAN MOTOR VEHICLE PRODUCTION

The importance of Lend-Lease trucks in the Red Army becomes more apparent when Soviet and German truck production is compared. Soviet domestic production averaged 8000 trucks per month while Lend-Lease imports averaged 11,500.32 Lend-Lease allowed the Soviet Union to de-emphasize vehicle production so that it could concentrate on tank and aircraft production. German truck production averaged 9,500 trucks per month (see Figure 32). ${ }^{33}$ However, according to OKW records 109,113 trucks were lost on the various fronts between January and August 1944.34 This amounted to 39 percent of the entire military stock available and was the entire production for 1943.35 Despite allied bombing German production of motor vehicles in 1944 was considerable (see Table XIII). Germany also received motor vehicles from the industries of occupied countries in Europe (see Table XIV). It becomes clear from Table XIV that Germany was the primary producer of German Army vehicles. The production of motor vehicles by the Soviet Union remained inferior to Germany and its supply from the occupied countries. Therefore, Lend-Lease provided the margin of superiority to the Red Army so that it achieved mechanized and motorized superiority over the Wehrmacht. The significance of this motorized superiority in the summer of 1944 was noted by one historian:

It is also doubtful that the Soviet Union could have conducted its immense offensives without Western aid. 
The assistance to transport and communications systems gave the Soviet forces a special advantage in massing their forces quickly, sustaining them during the "buildup" phase of an attack, and supporting them during offensives which ranged 300-400 miles in depth. ...Without Western aid in this phase of the war the Soviet Union would still have survived, and probably eventually would have won. But without Lend-Lease, victory would have been postponed, and the Soviet share of victory and presence in eastern and central Europe reduced. 36

Soviet truck production was very inadequate and was cut in half during the war. ${ }^{37}$ When American trucks became abundant Soviet production was scaled back even further. Soviet domestic truck production from 1942-1945 was approximately 197,100.38 The tremendous numbers of Lend-Lease trucks, jeeps, motorcycles and other vehicles provided not only the mobility for the Red Army, but permitted the Soviet Union to concentrate productive capacity in the manufacture of tanks and aircraft. ${ }^{39}$

\section{SOVIET AND GERMAN TANK PRODUCTION}

Soviet industry freed from the constraints of having to produce masses of trucks was able to concentrate on tank production. The Soviet Union produced 79,611 tanks compared to 25,006 produced by Germany. 40 The total number of tanks and selfpropelled guns produced by the Soviet Union was approximately 112,952 (see Table XV).41 Total German production of tanks and self-propelled guns amounted to 46,742 vehicles or 41 percent of the total Soviet production (see Table XVI). ${ }^{42}$ Table XVII delineates 
the Soviet superiority in tank production as compared to German tank production during the war. Lend-Lease armored vehicle shipments to the Soviet Union were extremely small (see Table XI) when compared to motor vehicle shipments. Thus, Lend-Lease aid permitted the Soviets to maintain and increase their tank strength (see Figure 33) by continued concentration on tank production since trucks and other motor transport were provided mostly by the United States. 
TABLE VII

ANNUAL LEND-LEASE SHIPMENTS TO THE SOVIET UNION (THOUSANDS OF TONS AND PERCENTAGE OF SOVIET TOTAL)

\begin{tabular}{llc} 
Year & Tons & Percent \\
\hline 1941 & 404 & 2 \\
1942 & 2,747 & 14 \\
1943 & 5,370 & 27 \\
1944 & 6,964 & 36 \\
1945 & $\underline{4,115}$ & $\underline{21}$ \\
Totals & 19,600 & 100 \\
\hline
\end{tabular}

Source: Hubert Paul Van Tuyll, "Lend-Lease And The Great Patriotic War, 1941-1945," (PH.D Thesis, Texas A \& M. University, December 1986), p. 105. 
TABLE VIII

LEND-LEASE SHIPMENTS TO THE USSR, JULY 1942-JUNE 1943 (THOUSANDS OF DOLLARS)

Lend-Lease Shipments

Ordnance and ammunition Aircraft and parts

Tanks and parts

Watercraft

Motor Vehicles and parts

Machinery and parts

Agricultural products

Total
Cost

$\$ 266,684$

$\$ 400,362$

$\$ 101,135$

$\$ 52,281$

$\$ 256,120$

$\$ 524,295$

$\$ 330.200$

Source: Hubert Paul Van Tuyll, "Lend-Lease And The Great Patriotic War, 1941-1945," (PH.D Thesis, Texas A \& M University, December 1986), p. 132; U.S. President, Reports to Congress Lend-Lease Operations, No. 16 (Washington D.C.: Government Printing Office, 1943-45), p. 30 . 
TABLE IX

LEND-LEASE SHIPMENTS TO THE USSR, JULY 1943-JUNE 1944 (THOUSANDS OF DOLLARS)

Lend-Lease Shipments

Ordance and ammunition

Aircraft and parts

Tanks and parts

Motor Vehicles and parts Industrial machinery and parts Agricultural products Naval equipment

Total

Source: Hubert Paul Van Tuyll, "Lend-Lease And The Great

Patriotic War, 1941-1945," (PH.D Thesis, Texas A \& M University, December 1986), p. 135; U.S. President, Reports to Congress Lend-Lease Operations, No. 16 (Washington D.C.: Government Printing Office, 1943-45), p. 30 .
$\$ 398,502$

$\$ 659,732$

$\$ 134,795$

$\$ 500,607$

$\$ 1,094,483$

$\$ 610,114$

$\$ 91.519$

$\$ 3,489,752$
Cost 


\section{TABLE $X$}

\section{AIRCRAFT DELIVERIES TO THE SOVIET UNION 1 OCTOBER 1941 - 31 JULY 1943}

\begin{tabular}{ll} 
Item & Number \\
\hline Pursuit planes & 1,555 \\
Bombers & 1,901 \\
Other aircraft & $\frac{191}{3,647}$ \\
Total & \\
\hline
\end{tabular}

Source: Hubert Paul Van Tuyll, "Lend-Lease And The Great Patriotic War, 1941-1945," (PH.D Thesis, Texas A \& M University, December 1986), p. 133. 
TABLE XI

VEHICLES DELIVERED TO THE SOVIET UNION UNDER THE LEND-LEASE PROGRAM

\begin{tabular}{llllll} 
Items & $\begin{array}{l}\text { Lend-Lease } \\
\text { Export }\end{array}$ & $\begin{array}{c}\text { Total } \\
\text { Exports }\end{array}$ & Arrived & $\begin{array}{l}\text { Lost } \\
\text { En Route }\end{array}$ & Diverted \\
\hline $\begin{array}{l}\text { Jeeps: } \\
1 / 4 \text { ton }\end{array}$ & 47,993 & 48,993 & 43,728 & 3,657 & 1,378 \\
$\begin{array}{l}4 \times 4 \\
\text { amphib. }\end{array}$ & 3,510 & 3,510 & 3,510 & 0 & 0 \\
Total & 51,503 & 52,503 & 47,238 & 3,657 & 1,378
\end{tabular}

Trucks:

$3 / 4$ ton

25,240

$25,240 \quad 24,564$

78

598

$11 / 2$ ton 153,415

$159,494 \quad 148,664$

6,660

1,826

$21 / 2$ ton 190,952

$21 / 2$ ton 589

193,603

182,938

4,300

589

586

3

1,130

amphib.

5 ton plus

special

858

814

0

0

\section{purpose}

Truck

2,792

2,792

2,784

8

0

0

tractors

1,941

1,960

1,938

6

0

w/o

trailer

Total

$375,781 \quad 384,536$

362,288

11,055

3,554 


\section{TABLE XI}

VEHICLES DELIVERED TO THE SOVIET UNION UNDER THE LEND-LEASE PROGRAM

(continued)

Items

Lend-Lease

Total

Arrived

Lost

Diverted

Export

Exports

En Route

Ordance

Service

Vehicles:

Field

1,543

1,543

1,543

9

0

repair

trucks

Tank

130

130

130

0

0

recovery

units

Tank

655

655

629

26

0

transporters

Total

2,328

2,328

2,293

35

0

Combat

Vehicles:

Light

1,682

1,682

1,239

443

0

tanks

Medium

5,374

5,374

4,957

417

0

tanks 
TABLE XI

VEHICLES DELIVERED TO THE SOVIET UNION

UNDER THE LEND-LEASE PROGRAM

(continued)

Items

Lend-Lease

Export

Arrived

Lost

Diverted

En Route

Self-

propelled

guns

AT

$75 \mathrm{~mm}$

AT

5

5

5

0

0

$57 \mathrm{~mm}$

650

650

650

0

0

AT 3in.

52

52

52

0

0

AT

100

100

100

0

0

$37 \mathrm{~mm}$

AA

1,000

1,000

1,000

0

0

$50 \mathrm{cal}$.

Half-

1,158

1,158

1,104

54

0

tracks

Armored

3,282

3,282

3,054

288

0

scout

cars

Total

13,303

13,303

12,161

1,142

0

Motor-

35,170

35,170

32,200

1,870

1,100

cycles

Track-

8,071

8,074

7,570

253

0

laying

tractors 
TABLE XI

VEHICLES DELIVERED TO THE SOVIET UNION

UNDER THE LEND-LEASE PROGRAM

(continued)

\begin{tabular}{|c|c|c|c|c|c|}
\hline Items & $\begin{array}{l}\text { Lend-Lease } \\
\text { Export }\end{array}$ & $\begin{array}{c}\text { Total } \\
\text { Exports }\end{array}$ & Arrived & $\begin{array}{l}\text { Lost } \\
\text { En Route }\end{array}$ & Diverted \\
\hline $\begin{array}{l}\text { Railway } \\
\text { Units: }\end{array}$ & & & & & \\
\hline $\begin{array}{l}\text { Steam } \\
\text { loco- } \\
\text { motives }\end{array}$ & 1,911 & 1,911 & 1,900 & 11 & 0 \\
\hline $\begin{array}{l}\text { Diesel } \\
\text { electric } \\
\text { loco- } \\
\text { motives }\end{array}$ & 70 & 70 & 66 & 4 & 0 \\
\hline $\begin{array}{l}\text { Flat cars } \\
\text { Tank } \\
\text { cars }\end{array}$ & $\begin{array}{l}10,000 \\
120\end{array}$ & $\begin{array}{l}10,000 \\
120\end{array}$ & $\begin{array}{l}9,920 \\
120\end{array}$ & $\begin{array}{l}80 \\
0\end{array}$ & $\begin{array}{l}0 \\
0\end{array}$ \\
\hline $\begin{array}{l}\text { Dump } \\
\text { cars }\end{array}$ & 1,000 & 1,000 & 1,000 & 0 & 0 \\
\hline $\begin{array}{l}\text { Heavy } \\
\text { machine } \\
\text { cars }\end{array}$ & 35 & 35 & 35 & 0 & 0 \\
\hline Total & 13,136 & 13,136 & 13,041 & 95 & 0 \\
\hline
\end{tabular}

Source: Robert Huhn Jones, The Roads to Russia: United States Lend-Lease to the Soviet Union (Norman: University of Oklahoma Press, 1969), Appendix A, Table IV; U.S.

Department of State. Protocol and Area Information Staff of the U.S.S.R. Branch of the Division of Research and Reports. "Report on war Aid Furnished by the United States to the U.S.S.R." Foreign Economic Section, Office of Foreign Liquidation, Department of State, November 28, 1945, pp. 19-21. 


\section{TABLE XII}

MOTOR VEHICLES AND RAILROAD TRANSPORTATION EQUIPMENT JUNE 22, 1941 - SEPTEMBER 2, 1945

Time Period June 22, 1941-Sept. 30,1941

Type of Cargo

Trucks and other

Vehicles

R.R. Transportation 0

Equipment

Oct. 1, 1941-June 30, 1942

Trucks and other

Vehicles
R.R. Transportation 0

Equipment

July $1,1942-J u n e$ 30,1943

Trucks and other

Vehicles

R.R. Transportation 0

Equipment

July $1,1943-J u n e$ 30,1944
Trucks and other

Vehicles

R.R. Transportation 70,466

Equipment Total Tonnage

\section{1,575}

214,164

448,488

742,337

July 1
1945
645,270

1944-May 12,

\section{Vehicles}

R.R. Transportation $\quad 355,739$ 


\section{TABLE XII}

MOTOR VEHICLES AND RAILROAD TRANSPORTATION EQUIPMENT JUNE 22, 1941 - SEPTEMBER 2, 1945

(continued)

Time Period

May 13, 1945-Sept.

2, 1945
Type of Cargo

Trucks and other

Vehicles

R.R. Transportation

Equipment
Total Tonnage

238,117

41,380

Total Tonnage:

Trucks and other Vehicles

R.R. Transportation Equipment

Source: Robert Huhn Jones, The Roads to Russia: United States Lend-Lease to the Soviet Union (Norman: University of Oklahoma Press, 1969), Appendix A, Table I; U.S. Department of State. Protocol and Area Information Staff of the U.S.S.R. Branch of the Division of Research and Reports. "Report on war Aid Furnished by the United States to the U.S.S.R." Foreign Economic Section, Office of Foreign Liquidation, Department of State, November 28, 1945, pp. 1-8. 
TABLE XIII

GERMAN PRODUCTION OF MOTOR VEHICLES 1944

Product

Quantity

\section{Trucks:}

Up to \& incl. 1.5-ton

3-ton (incl. "Mules")

4.5-ton \& up (incl. "Mules")

Caterpillar truck (RSO)

Total
22,383

43,062

10,711

$\underline{11.942}$

88,088

Half-tracks and special vehicles 17,736

Automobiles

21,656

Motorcycles

30,372

Motorcycle half-tracks

4,490

Tractors 1.013

Source: The United States Strategic Bombing Survey, German Motor Vehicles Industry Report, Munitions Division, January 1947, p. 13. 
TABLE XIV

MOTOR VEHICLE PRODUCTION IN OCCUPIED COUNTRIES

Country and Type 1943 1944

FRANCE:

2-Ton Trucks

3.5-Ton Trucks

4.5-Ton Trucks

Total Trucks

ITALY:

3-Ton Trucks

4.5-Ton Trucks

Total Trucks

Tractors
3,228

4,757

1.374

9,359

0

0

0

0
0

3,674

784

4,458

CZECHOSLOVAKIA:

3-Ton Trucks

Automobiles

Motorcycles
1,376

1,261 498
5,402

$\underline{646}$

6,048

172

Source: The United States Strategic Bombing Survey, German Motor Vehicles Industry Report, Munitions Division, January 1947, Exhibit E, pp. 1-2. 
TABLE XV

SOVIET ARMORED VEHICLE PRODUCTION IN THE SECOND WORLD WAR

\begin{tabular}{|c|c|c|c|c|c|c|}
\hline Type & 1940 & 1941 & 1942 & 1943 & 1944 & 1945 \\
\hline $\begin{array}{l}\text { Misc. } \\
\text { T-226 }\end{array}$ & $\begin{array}{l}125 \\
1549\end{array}$ & & & & & \\
\hline $\begin{array}{l}\text { T-26 } \\
\text { BT -8 }\end{array}$ & $\begin{array}{l}1,049 \\
706\end{array}$ & & & & & \\
\hline T.28 & 12 & & & & & \\
\hline$T-40$ & & 41 & 181 & & & \\
\hline$T-50$ & & 48 & 15 & & & \\
\hline$T-60$ & & 1,818 & 4,474 & & & \\
\hline$T-70$ & & & 4,883 & 3,343 & & \\
\hline$T-80$ & & & & 120 & & \\
\hline$T-34$ & 117 & 3,014 & 12,553 & 15,712 & 3,723 & \\
\hline $\begin{array}{l}T-34- \\
85\end{array}$ & & & & 100 & 11,000 & 18,330 \\
\hline T. 44 & & & & & & 200 \\
\hline$K V-1$ & 141 & 1,121 & 1,753 & & & \\
\hline$K V-2$ & 102 & 232 & & & & \\
\hline$K V-1 S$ & & & 780 & 452 & & \\
\hline$K V-85$ & & & & 130 & & \\
\hline IS-2 & & & & 102 & 2,252 & 1,500 \\
\hline SU -76* & & & 26 & 1,928 & 7,155 & 3,562 \\
\hline SU-122 & & & 25 & 630 & 493 & \\
\hline SU-85 & & & & 750 & 1,300 & \\
\hline SU-100 & & & & & 500 & 1,175 \\
\hline SU-152 & & & & 704 & & \\
\hline ISU-122 & & & & 35 & 2,510 & 1,530 \\
\hline
\end{tabular}

\begin{tabular}{lllllll} 
Totals & 2,752 & 6,274 & 24.690 & 24.006 & 28.933 & 26,297 \\
\hline
\end{tabular} *SU-76 figures include small number of ZSU-37 production; 1945 figures refer only to first six months.

Source: Steven J. Zaloga and James Grandsen, Soviet Tanks And Combat Vehicles of World War Two (London: Arms and Armour Press, 1984), p. 225. 


\section{TABLE XVI}

GERMAN PANZER PRODUCTION: TANKS, ASSAULT GUNS AND SELF-PROPELLED GUNS

\begin{tabular}{|c|c|c|c|c|c|c|}
\hline PANZERS & 1940 & 1941 & 1942 & 1943 & 1944 & 1945 \\
\hline $\begin{array}{l}\text { Mark I and II } \\
\text { Mark III }\end{array}$ & $\begin{array}{l}9 \\
895\end{array}$ & $\begin{array}{l}233 \\
1.845\end{array}$ & $\begin{array}{l}306 \\
2.555\end{array}$ & $\begin{array}{l}77 \\
349\end{array}$ & 7 & \\
\hline $\begin{array}{l}\text { Mark IV } \\
\text { Tank Destroyer } \\
\text { IV }\end{array}$ & 280 & 480 & 964 & 3,073 & $\begin{array}{l}3,371 \\
1,764\end{array}$ & $\begin{array}{l}417 \\
458\end{array}$ \\
\hline $\begin{array}{l}\text { Assault Gun } \\
\text { III/IV }\end{array}$ & 184 & 550 & 828 & 3,319 & 5,884 & 1,061 \\
\hline $\begin{array}{l}\text { Panther } \\
\text { Jagd-Panther }\end{array}$ & & & & 1,850 & $\begin{array}{l}3,964 \\
215\end{array}$ & $\begin{array}{l}469 \\
166\end{array}$ \\
\hline Tiger I & & & 75 & 647 & 623 & \\
\hline Tiger II & & & & & 377 & 112 \\
\hline $\begin{array}{l}\text { Jagd-Tiger } \\
\text { Self-Propelled } \\
\text { Guns }\end{array}$ & & & 1,248 & $\begin{array}{l}2 \\
2,557\end{array}$ & $\begin{array}{l}51 \\
1,248\end{array}$ & $\begin{array}{l}26 \\
87\end{array}$ \\
\hline $\begin{array}{l}\text { Total German } \\
\text { Panzers }\end{array}$ & 1,368 & 3,108 & 5,979 & 11,874 & 17,504 & 2,796 \\
\hline $\begin{array}{l}\text { Jagd }-38 \\
38 \mathrm{t} \\
\text { Total Panzers }\end{array}$ & $\begin{array}{l}275 \\
1,643\end{array}$ & $\begin{array}{l}698 \\
3,806\end{array}$ & $\begin{array}{l}195 \\
6,174\end{array}$ & $\begin{array}{l}87 \\
11,961\end{array}$ & $\begin{array}{l}1,598 \\
124 \\
19,226\end{array}$ & 1,136 \\
\hline
\end{tabular}

*German 1945 figures refer only to the first three months.

Source: The United States Strategic Bombing Survey, Tank Industry Report, Munitions Division, January 1947, Exhibit A. 
TABLE XVII

COMPARISON OF SOVIET AND GERMAN ARMORED VEHICLE PRODUCTION

1940-1945

\begin{tabular}{lcc} 
Year & Soviet Production & German Production \\
\hline 1940 & 2,752 & 1,643 \\
1941 & 6,274 & 3,806 \\
1942 & 24,690 & 6,174 \\
1943 & 24,006 & 11,961 \\
1944 & 28,933 & 19,226 \\
1945 & $\underline{26,297}$ & 3,932 \\
Totals & 112,952 & 46,742 \\
\hline
\end{tabular}

"Soviet 1945 figures refer only to the first six months;

German 1945 figures refer only to the first three months.

Source: The United States Strategic Bombing Survey, Tank Industry Report, Munitions Division, January 1947, Exhibit A; Steven J. Zaloga and James Grandsen, Soviet Tanks and Combat Vehicles of World War Two (London: Arms and Armour Press, 1984), p. 225. 


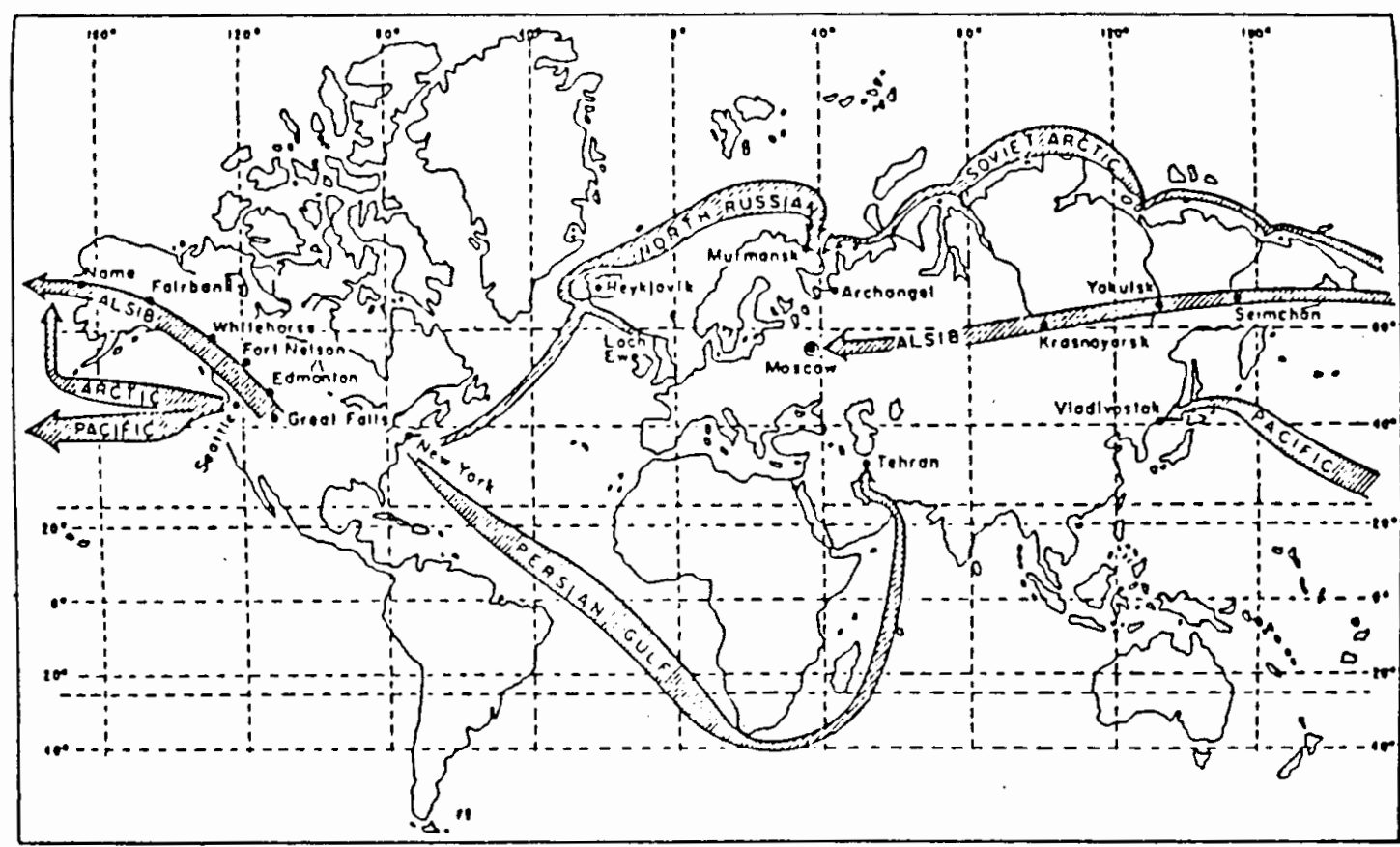

Figure 29. Routes To Russia. Source: Robert Huhn Jones, The Roads to Russia: United States Lend-Lease to the Soviet Union (Norman: University of Oklahoma Press, 1969), p. 83. 


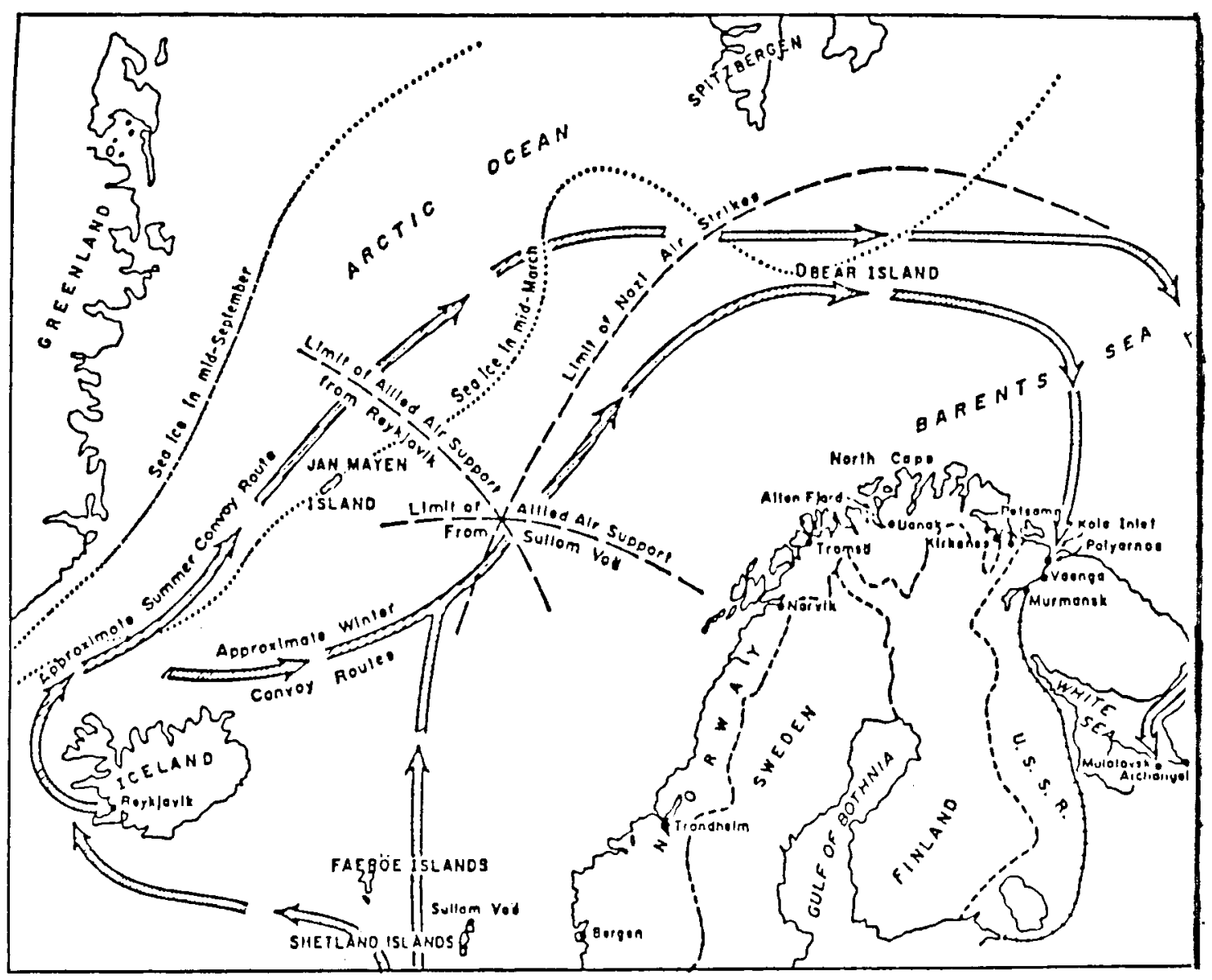

Figure 30. Convoy Routes To North Russia. Source:

Robert Huhn Jones, The Roads to Russia: United States Lend-Lease to the Soviet Union (Norman: University of Oklahoma Press, 1969), p. 101. 


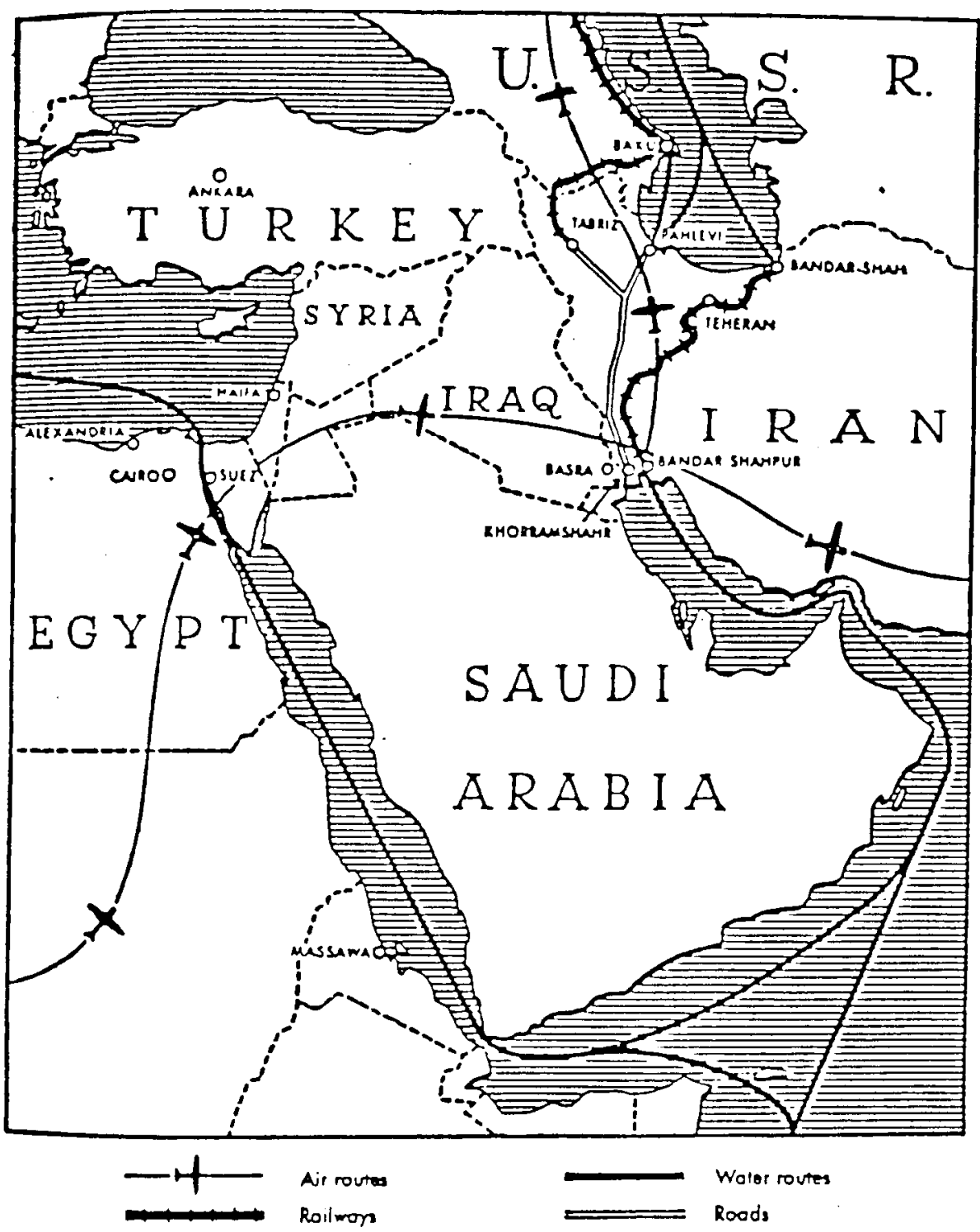

Figure 31. Middle East Supply Routes. Source: Edward R. Stettinius, Jr., Lend-Lease (New York: The Macmillan, Company, 1944), p. 137. 


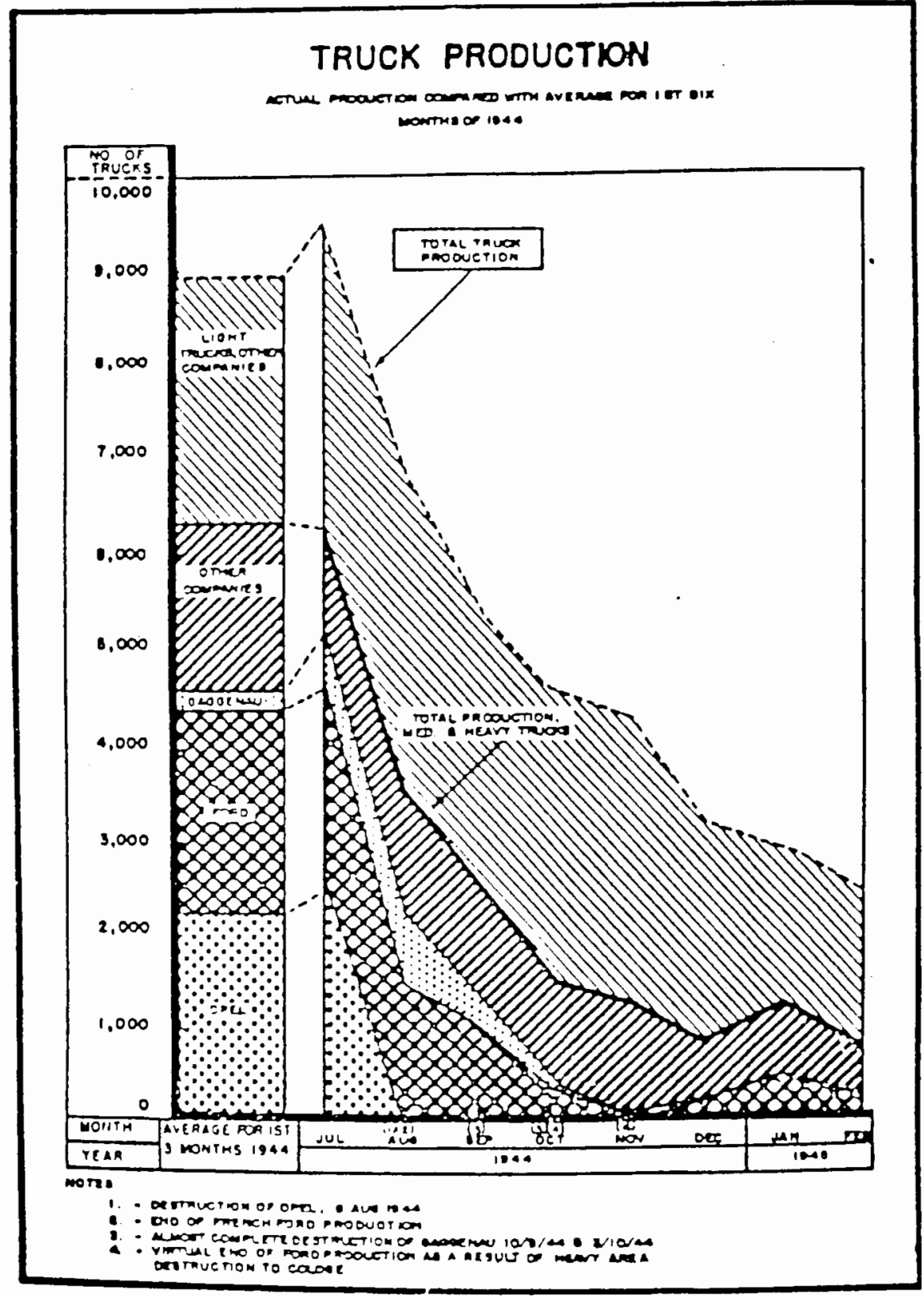

Figure 32. German Truck Production. Source: The United States Strategic Bombing Survey, German Motor Vehicles Industry Report, Munitions Division, January 1947, Figure 3. 


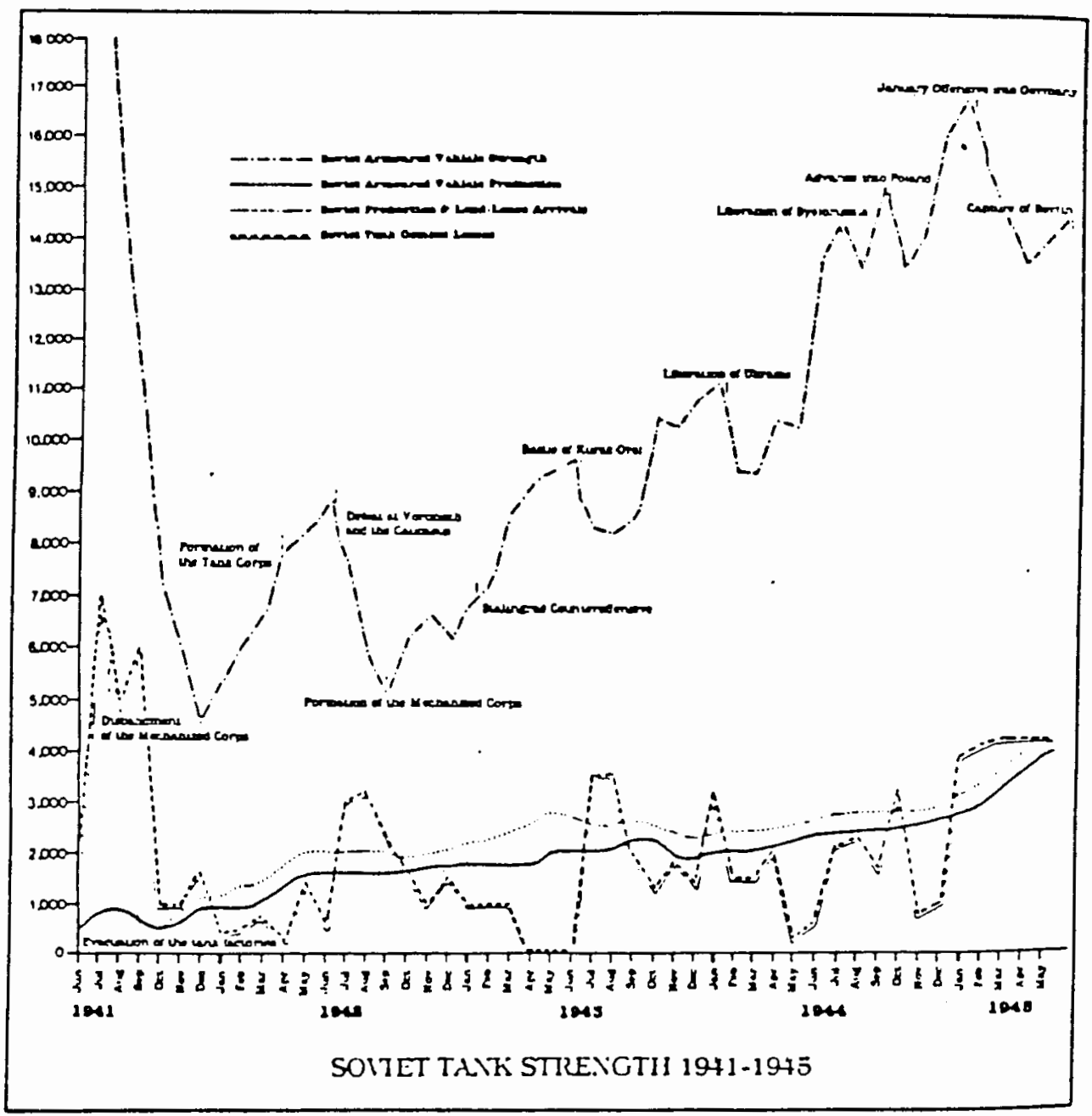

Figure 33. Soviet Tank Strength 1941-1945. Source: Steven J. Zaloga and James Grandsen, Soviet Tanks And Combat Vehicles of World War Two (London: Arms and Armour Press, 1984), p. 224. 


\section{NOTES TO CHAPTER V}

1Hubert Paul Van Tuyll, "Lend-Lease And The Great Patriotic War, 1941. 1945," (PH.D Thesis, Texas A\&M University, December 1986), p. 72; Alexander Werth, Russia At War 1941-1945 (New York: Carroll \& Graf Publishers, Inc., 1964), p. 627.

2Van Tuyll, p. 72; Oleg Rzheshevsky, World War II: Myths and the Realties (Moscow: Progress Publishers, Inc., 1964), p. 185.

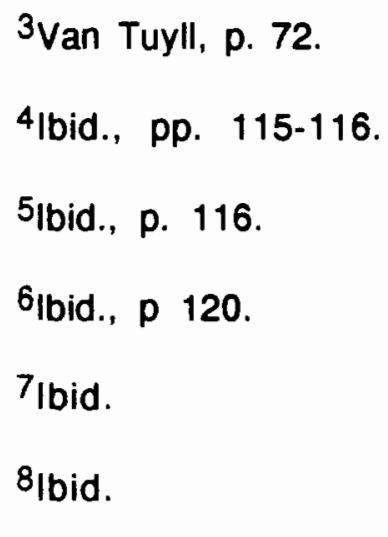

9John Keegan, The Second World War (New York: Viking Penguin Books Inc., 1990), p. 122.

${ }^{10}$ Van Tuyll, p. 116

$11_{\text {Ibid., p. } 226 .}$

12 Ibid., p. 227.

${ }^{13}$ Edward R. Stettinius, Jr., Lend-Lease (New York: The Macmillan Company, 1944), p. 226.

14 ibid., p.222.

15Van Tuyll, p. 119.

16 Werth, p. 625.

17Walter Schwabedissen, The Russian Air Force in the Eyes of German Commanders (New York: Arno Press, 1960), p. 385.

${ }^{18}$ Alexander Boyd, The Soviet Air Force Since 1918 (New York: Stein and Day Publishers, 1977), p. 180; Robert A. Kilmarx, A Histroy of Soviet Air Power (New York: Frederick A. Praeger, Inc., 1962), p. 191. 
${ }^{19}$ Alan Clark, The Russian-German Conflict 1941-45 (New York: William Morrow and Company inc., 1965), p. 372.

20 John Erickson, The Road to Berlin (Boulder, Colorado: Westview Press, 1983), p. 81.

21George C. Herring, Jr., Aid To Russia 1941-1946 (New York: Columbia University Press, 1973), p. 118.

22Van Tuyll, p. 124; U.S. President, Report on Operations of the Foreign Economic Administration (Washington, D.C.: Government Printing Office, 1944), pp. 29-30.

${ }^{23}$ Noel F. Mason, "Observing the Russians at War," Military Review, No. 28 (May 1948), p. 101.

24/bid.; Van Tuyll, p. 123.

25Ibid.

26John R. Deane, The Strange Alliance (New York: The Viking Press, 1947), p. 93.

27|bid., pp. 93-94, 206.

28 ibid., p. 207.

29Albert Seaton, The Russo-German War 1941-45 (New York: Praeger Publishers, Inc., 1972), p. 421.

30lbid.

31 Ibid., p. 352.

320.S.S., "Postwar Economic Policies and Capabilities of the U.S.S.R.," Joint Chiefs of Staff (November 1, 1945), p. 18; O.S.S., "Relative Capabilities on the Eastern Front," 0. S.S. State Department Intelligence and Research Reports. Part VI: The Soviet Union, 1941-1949 (Frederick, M.D.: University Publications of America, 1977), (May 1, 1944), p. 10.

33The United States Strategic Bombing Survey, German Motor Vehicles Industry Repert, Munitions Division, January 1947, p. 14.

34 Ibid., p. 17.

$35 \mathrm{Ibid}$. 
36Van Tuyll, pp. 128-129.

37Ibid., p. 196.

${ }^{38}$ Roger Munting, "Lend-Lease and the Soviet War Effort," Joumal of Contemporary History Vol. 19, No. 3 (July 1984), p. 500; E. Zaleski, Stalinist Planning for Economic Growth 1932-52 (Chapel Hill, 1980), p. 604.

${ }^{39}$ Robert Huhn Jones, The Roads to Russia: United States Lend-Lease to the Soviet Union (Norman: University of Oklahoma Press, 1969), p. 237.

${ }^{40}$ Steven J. Zaloga and James Grandsen, Soviet Tanks And Combat Vehicles of World War Two (London: Arms and Armour Press, 1984), p. 222.

${ }^{41}$ lbid., p. 225.

42The United States Strategic Bombing Survey, Tank Industry Report, Munitions Division, January 1947, Exhibit A. 
CHAPTER VI

\section{THE SECOND FRONT: THE IMPACT ON GERMAN MOBILE RESERVES}

The necessity of fighting on several fronts reduced the concentration of military forces on any one front. The Soviet Union benefited from the dispersion of German forces. Both the Soviet and Anglo-American forces had the good fortune to only have to fight against a portion of the German Army on any given front while the Germans had to face the full brunt of each of the allied armies on their respective fronts. In the summer of 1944, the Soviets would have had to confront a much larger and more mobile German Army if there had not been an active Anglo-American second front. The Anglo-American forces tied down sufficient German infantry, Panzer Grenadier and Panzer divisions that the Soviet summer offensive achieved much of its success because the German reserves which could have been used to halt the offensive were engaged against Anglo-American forces. The most significant reserves the Wehrmacht had to prevent Soviet breakthroughs were its mobile formations and 49 percent of these units were located in the West. However, if the 2nd Hungarian Panzer Division and the 1st Rumanian Panzer Division are excluded and only German mobile 
units are compared then the ratio becomes 51 percent in the West and 49 percent in the East when the Soviet summer offensive began (see Tables XVIII \& XX). If the mobile formations in the West had been available in the East during the summer of 1944 the outcome of the Soviet summer offensive would have been different.

\section{GERMAN ORDER OF BATTLE IN THE WEST AND THE EAST IN THE SUMMER OF 1944}

The German military had 79 infantry divisions, 9 Luftwaffe field divisions, 5 parachute divisions, 1 air landing division, 5 Jaeger divisions, 5 mountain divisions, 2 cavalry divisions, 8 Panzer Grenadier divisions, and 15 Panzer divisions located in the West in June 1944 (see Tables XVIII \& XIX). The German and Axis order of battle in the East contained 130 German infantry divisions, 4 German Luftwaffe field divisions, 7 German Jaeger divisions, 5 German mountain divisions, 6 German Panzer Grenadier divisions, 16 German Panzer divisions, 11 Hungarian infantry divisions, 1 Hungarian Panzer division, 18 Rumanian infantry divisions, 2 Rumanian mountain divisions, 1 Rumanian Panzer division and 1 Slovakian infantry division (see Tables $X X \& X X I$ ).

A comparison of non-mobile divisions in the West and the East as delineated in Table XIX and Table XXI show the bulk of nonmobile divisions to be in the East. According to Tables $X I X$ and $X X I$, 58 percent of German non-mobile divisions were located in the East and 42 percent were in the West in June 1944. However, when all 
Eastern European Axis divisions are also calculated into the total axis military force then the percentage of military power in the West declines in comparison to the East. A ratio of German and Axis Allies in the East when compared to the West shows that 63 percent of all German and Axis non-mobile divisions were in the East compared to 37 percent in the West.

Therefore, the majority of German and Axis divisions were deployed in the East. However, 51 percent of all German mobile divisions and 42 percent of all non-mobile German divisions were located in the West. This military deployment in the West amounted to 128 divisions of which more than half would have been available to fight in the East if there had been no second front. Soviet success in the East was achieved because of German weakness and German weakness resulted from fighting a two-front war. If the German forces in the West had been mostly available to fight in the East then the outcome of the war in the East would have been different. German mobile reserves were absolutely critical to the success of German defense against Soviet breakthroughs and half of these reserves were needed to prevent an Anglo-American breakthrough in the West. Therefore, the second front pinned down the critical reserves needed to prevent the Soviet breakthrough in the East in the summer of 1944. 
TABLE XVIII

GERMAN MOBILE DIVISIONS, ORDER OF BATTLE IN THE WEST

JUNE 1944

Country and Army

DENMARK

Mobile Divisions

233rd Reserve Panzer Division

O.B. WEST

NETHERLANDS

19th Panzer Division

FRANCE:

Army Group B

2nd Panzer Division

116th Panzer Division

9th SS Panzer Division

"Hohenstaufen"

10th SS Panzer Division

"Frundsberg"

15th Army:

1st SS Panzer Division

"Leibstandarte SS Adolf Hitler"

7th Army:

21st Panzer Division

12th SS Panzer Division

"Hitlerjugend"

17th SS Panzer Grenadier

Division "Goetz Von

Berlichingen"

Panzer Lehr Division

Army Group G:

2nd SS Panzer Division "Das

Reich"

9th Panzer Division

1st Army:

11th Panzer Division

O.B. SOUTHWEST

ITALY

14th Army:

3rd Panzer Grenadier Division 29th Panzer Grenadier Division 90th Panzer Grenadier Division 26th Panzer Division

10th Army: 1st Fallschirm Panzer Division "Herman Goering" 


\section{TABLE XVIII}

GERMAN MOBILE DIVISIONS, ORDER OF BATTLE IN THE WEST

JUNE 1944

(continued)

Country and Army

10th Army:

Army Detachment Von Zangen:

O.B. SOUTHEAST
Mobile Divisions

15th Panzer Grenadier Division

16th SS Panzer Grenadier

Division "Reichsfuehrer SS"

18th SS Panzer Grenadier

Division "Horst Wessel"

Army Group E

GRECE

4th SS Panzer Grenadier

Division "Polizei"

Total Mobile Divisions:

Panzer Grenadier Divisions

8 Divisions

Panzer Divisions

15 Divisions

Total Mobile Divisions

23 Divisions

Source: Kurt Mehner, Die Geheimen Tagesberichte Der Deutschen Wehrmachtfuehrung Im Zweiten Weltkrieg 1939-1945 Vol. 10 (Osnabrueck: Biblio Verlag, 1985), pp. 502-504; lan V. Hogg, German Order of Battle 1944 (New York: Hippocrene Books Inc., 1975), pp. D2-D136; Samuel W. Mitchum, Jr. Hitler's Legions: The German Army Order of Battle. World War II (Now York: Stein and Day Publishers, 1985), pp. 41473; Rolf Stoves, Die Gepanzerten und Motorisierten Deutschen Grossverbande 1935-1945 (Friedburg: PodzunPallas-Verlag GmbH, 1986), pp. 11-276; W. Victor Madej, German Army Order of Battle 1939-1945 Vols. I-II, Supplement (Allentown, Pennsylvania: Game Marketing Company, 1981); W. Victor Madej, Southeastern Europe Axis Armed Forces Order of Battle (Allentown, Pennsylvania: Game Marketing Company, 1982), pp. 26-46; Der Grosse Durchbruch bei Heeresgruppe Mitte Von 21.6. 10.8.44, National Archives Microfilm Publication T.78 Roll 136. 
TABLE XIX

GERMAN ORDER OF BATTLE IN THE WEST FOR INFANTRY PARACHUTE, AIR LANDING, JAEGER, MOUNTAIN, CAVALRY, AND LUFTWAFFE FIELD DIVISIONS

IN JUNE 1944

Country and Army
NORWAY

DENMARK

O.B. WEST

NETHERLANDS
Divisions

89th Infantry Division

196th Infantry Division

199th Infantry Division

230th Infantry.Division

269th Infantry Division

270th Infantry Division

274th Infantry Division

280th Infantry Division.

295th Infantry Division

702nd Infantry Division

710th Infantry Division

14th Luftwaffe Field Division

160th Reserve Infantry Division

166th Reserve Infantry Division

363rd Infantry Division

416th Infantry Division

347th Infantry Division

719th Infantry Division

16th Luftwaffe Field Division

FRANCE

15th Army: 47th Infantry Division 


\section{TABLE XIX}

GERMAN ORDER OF BATTLE IN THE WEST FOR INFANTRY PARACHUTE, AIR LANDING, JAEGER, MOUNTAIN, CAVALRY, AND LUFTWAFFE FIELD DIVISIONS

IN JUNE 1944

(continued)

Country and Army 15th Army:

7th Army
Divisions

48th Infantry Division

49th Infantry Division

84th Infantry Division

85th Infantry Division

165th Reserve Infantry Division

182nd Reserve Infantry Division

245th Infantry Division

326th Infantry Division

331st Infantry Division

344th Infantry Division

346th Infantry Division

348th Infantry Division

711th Infantry Division

712th Infantry Division

17th Luftwaffe Field Division

18th Luftwaffe Field Division

77th Infantry Division

91st Air Landing Division

243rd Infantry Division

265th Infantry Division

266th Infantry Division

275th Infantry Division

319th Infantry Division

343rd Infantry Division

352nd Infantry Division

353rd Infantry Division

709th Infantry Division

716th Infantry Division

2nd Parachute Division 
TABLE XIX

GERMAN ORDER OF BATTLE IN THE WEST FOR INFANTRY PARACHUTE, AIR LANDING, JAEGER, MOUNTAIN, CAVALRY, AND LUFTWAFFE FIELD DIVISIONS

IN JUNE 1944

(continued)

Country and Army

7th Army

Army Group G

1st Army

19th Army

O.B. SOUTHWEST

ITALY

14th Army

10th Army
Divisions

3rd Parachute Division

5th Parachute Division

189th Reserve Infantry Division

158th Reserve Infantry Division

159th Reserve Infantry Division

276th Infantry Division

708th Infantry Division

148th Reserve Infantry Division

157th Reserve Infantry Division

242nd Infantry Division

244th Infantry Division

271st Infantry Division

272nd Infantry Division

277th Infantry Division

338th Infantry Division

715th Infantry Division

65th Infantry Division

92nd Infantry Division

162nd Infantry Division

356th Infantry Division

362nd Infantry Division

19th Luftwaffe Field Division

20th Luftwaffe Field Division

4th Parachute Division

71st Infantry Division

94th Infantry Division

278th Infantry Division

305th Infantry Division

334th Infantry Division 


\section{TABLE XIX}

GERMAN ORDER OF BATTLE IN THE WEST FOR INFANTRY PARACHUTE, AIR LANDING, JAEGER, MOUNTAIN, CAVALRY, AND LUFTWAFFE FIELD DIVISIONS IN JUNE 1944 (continued)

Country and Army

10th Army
Army Detachment Von Zangen
O.B. SOUTHEAST

2nd Panzer Army
Army Group $E$ GPECE
Divisions

1st Parachute Division 5th Mountain Division 114th Jaeger Division 42nd Jaeger Division 19th Luftwaffe Field Division 98th Infantry Division 1st Mountain Division 8th SS Cavalry Division "Florian Geyer" 181st Infantry Division 264th Infantry Division 297th Infantry Division 369th Infantry Division 373rd Infantry Division 392nd Infantry Division 1st Cossack Cavalry Division 118th Jaeger Division "Brandenburg "

7th SS Mountain Division "Prinz Eugen"

13th SS Mountain Division

"Handschar" (Croation \#1)

21st SS Mountain Division (Albanian \#1)
22nd Infantry
41st Fortress Division
133rd Fortress Division
104th Jaeger Division
117th Jaeger Division 
TABLE XIX

GERMAN ORDER OF BATTLE IN THE WEST FOR INFANTRY PARACHUTE, AIR LANDING, JAEGER, MOUNTAIN, CAVALRY, AND LUFTWAFFE FIELD DIVISIONS IN JUNE 1944

(continued)

Country and Army

Divisions

Army Group $E$

GRECE

440th Assault Division "Rhodos"

11th Luftwaffe Field Division

TOTAL DIVISIONS:

Infantry Divisions: $\quad 79$

Luftwaffe Field Divisions: 8

Parachute Divisions: 5

Air Landing Divisions: 1

Jaeger Divisions: 5

Mountain Divisions: 5

Cavalry Divisions: $\underline{2}$

Total: $\quad 105$

Source: Kurt Mehner, Die Geheimen Tagesberichte Der Deutschen Wehrmachtfuehrung Im Zweiten Weltkrieg 1939-1945 Vol. 10 (Osnabrueck: Biblio Verlag, 1985), pp. 502-504; Ian V. Hogg, German Order of Battle 1944 (New York: Hippocrene Books Inc., 1975), pp. D2-D136; Samuel W. Mitchum, Jr. Hitler's Legions: The German Army Order of Battle. World War II (New York: Stein and Day Publishers, 1985), pp. 41473; Rolf Stoves, Die Gepanzerten und Motorisierten Deutschen Grossverbande 1935-1945 (Friedburg: PodzunPallas-Verlag GmbH, 1986), pp. 11-276; W. Victor Madej, German Army Order of Battle 1939-1945 Vols. I-II, Supplement (Allentown, Pennsylvania: Game Marketing Company, 1981); W. Victor Madej, Southeastern Europe Axis Armed Forces Order of Battle (Allentown, Pennsylvania: Game Marketing Company, 1982), pp. 26-46; Der Grosse Durchbruch bei Heeresgruppe Mitte Von 21.6. 10.8.44, National Archives Microfilm Publication T-78 Roll 136. 


\section{TABLE XX}

GERMAN MOBILE DIVISIONS, ORDER OF BATTLE IN THE EAST JUNE 1944

Army Group and Army

ARMY GROUP NORTH

Army Detachment Narva

ARMY GROUP CENTER

4th Army

9th Army

ARMY GROUP NORTH UKRAINE 1st Hungarian Army

1st Panzer Army

4th Panzer Army

ARMY GROUP SOUTH UKRAINE 6th Army

8th Army

4th Rumanian Army
Mobile Divisions

12th Panzer Division

11th SS Panzer Grenadier

"Nordland"

60th Panzer Grenadier Division "Feldherrnhalle"

18th Panzer Grenadier Division 25th Panzer Grenadier Division 20th Panzer Division

16th Panzer Division

2nd Hungarian Panzer Division

1st Panzer Division

7th Panzer Division

8th Panzer Division

17th Panzer Division

20th Panzer Grenadier Division

4th Panzer Division

5th Panzer Division

1st Rumanian Panzer Division

3rd Panzer Division

10th Panzer Grenadier Division

13th Panzer Division

23rd Panzer Divsion

Panzer Division

"Grossdeutschland"

3rd SS Panzer Division

"Totenkopf" 


\section{TABLE $X X$}

GERMAN MOBILE DIVISIONS, ORDER OF BATTLE

IN THE EAST JUNE 1944

(continued)

Army Group and Army

4th Rumanian Army

TOTAL MOBILE DIVISIONS

Panzer Greandier Divisions

Panzer Divisions

Total German Mobile divisions

2nd Hungarian Panzer Division

1st Rumanian Panzer Division

Total Mobile Divisions
Mobile Divisions

14th Panzer Division

24th Panzer Division

Source: Kurt Mehner, Die Geheimen Tagesberichte Der Deutschen Wehrmachtfuehrung Im Zweiten Weltkrieg 1939-1945 Vol. 10 (Osnabrueck: Biblio Verlag, 1985), pp. 502-504; lan V. Hogg, German Order of Battle 1944 (New York: Hippocrene Books Inc., 1975), pp. D2-D136; Samuel W. Mitchum, Jr. Hitler's Legions: The German Army Order of Battle. World War II (New York: Stein and Day Publishers, 1985), pp. 41473; Rolf Stoves, Die Gepanzerten und Motorisierten Deutschen Grossverbande 1935-1945 (Friedburg: PodzunPallas-Verlag GmbH, 1986), pp. 11-276; W. Victor Madej, German Army Order of Battle 1939-1945 Vols. I-II, Supplement (Allentown, Pennsylvania: Game Marketing Company, 1981); W. Victor Madej, Southeastern Europe Axis Armed Forces Order of Battle (Allentown, Pennsylvania: Game Marketing Company, 1982), pp. 26-46; Der Grosse Durchbruch bei Heeresgruppe Mitte Von 21.6. 10.8.44, National Archives Microfilm Publication T-78 Roll 136. 
TABLE XXI

GERMAN AND AXIS ORDER OF BATTLE IN THE EAST FOR

INFANTRY, JAEGER, MOUNTAIN AND LUFTWAFFE

FIELD DIVISIONS IN JUNE 1944

Army Group

FINLAND

20th Mountain Army

ARMY GROUP NORTH

16th Army

Divisions

163rd Infantry Division
169th Infantry Division
210th Infantry Division
2nd Mountain Division
6th Mountain Division
7th Mountain Division

Field Training Division "Nord" 21st Infantry Division

23rd Infantry Division

24th Infantry Division

30th Infantry Division

32nd Infantry Division

69th Infantry Division

81st Infantry Division

83rd Infantry Division

87th Infantry Division

93rd Infantry Division

121st Infantry Division

126th Infantry Division

132nd Infantry Division

205th Infantry Division

207th Infantry Division

212th Infantry Division

215th Infantry Division

218th Infantry Division 
TABLE $X X \mid$

GERMAN AND AXIS ORDER OF BATTLE IN THE EAST FOR

INFANTRY, JAEGER, MOUNTAIN AND LUFTWAFFE

FIELD DIVISIONS IN JUNE 1944

(continued)

Army Group

16th Army

Army Detachment Narva

ARMY GROUP CENTER

3rd Panzer Army
Divisions

263rd Infantry Division

281st Infantry Division

285th Security Division

290 Infantry Division

300th Division Z.B.V.

329th Infantry Division

389th Infantry Division

15th SS Waffen-Grenadier

Division (Latvian \#1)

19th SS Waffen-Grenadier

Division (Latvian \#2)

12th Luftwaffe Field Division

21st Luftwaffe Field Division

11th Infantry Division

58th Infantry Division

61st Infantry Division

122nd Infantry Division

170th Infantry Division

225th Infantry Division

227th Infantry Division

285th Security Division

20th SS Waffen-Grenadier

Division (Estonian \#1)

390th Field training Division

14th Infantry Division

707th Infantry Division

95th Infantry Division

197th Infantry Division

201st Security Division

206th Infantry Division 
TABLE XXI

GERMAN AND AXIS ORDER OF BATTLE IN THE EAST FOR INFANTRY, JAEGER, MOUNTAIN AND LUFTWAFFE FIELD DIVISIONS IN JUNE 1944

(continued)

Army Group 3rd Panzer Army

4th Army

9th Army

2nd Army
Divisions

221st Security Division

246th Infantry Division

252nd Infantry Division

256th Infantry Division

299th Infantry Division

391st Security Division

4th Luftwaffe Field Division

6th Luftwaffe Field Division

12th Infantry Division

31st Infantry Division

57th Infantry Division

78th "Sturm" Division

110th Infantry Division

260th Infantry Division

267th Infantry Division

286th Security Division

337th Infantry Division

6th Infantry Division

35th Infantry Division

36th Infantry Division

45th Infantry Division

102nd Infantry Division

129th Infantry Division

134th Infantry Division

292nd Infantry Division

296th Infantry Division

383rd Infantry Division

7th Infantry Division

137th Infantry Division

203rd Security Division

211th Infantry Division 
TABLE XXI

GERMAN AND AXIS ORDER OF BATTLE IN THE EAST FOR INFANTRY, JAEGER, MOUNTAIN AND LUFTWAFFE

FIELD DIVISIONS IN JUNE 1944

(continued)

Army Group

2nd Army

Divisions

251st Infantry Division

5th Jaeger Division

1st Hungarian Infantry Division

5th Hungarian Reserve Infantry

Division

12th Hungarian Reserve Infantry

Division

23rd Hungarian Reserve Infantry

Division

ARMY GROUP NORTH UKRAINE 4th Panzer Army

26th Infantry Division

72nd Infantry Division

88th Infantry Division

131st Infantry Division

183rd Infantry Division

214th Infantry Division

217th Infantry Division

253rd Infantry Division

291st Infantry Division

339th Infantry Division

340th Infantry Division

342nd Infantry Division

361st Infantry Division

454th Security Division

1st Ski Jaeger Division

28th Jaeger Division

1st Panzer Army

1st Infantry Division

75th Infantry Division

96th Infantry Division

168th Infantry Division 


\section{TABLE XXI}

\section{GERMAN AND AXIS ORDER OF BATTLE IN THE EAST FOR INFANTRY, JAEGER, MOUNTAIN AND LUFTWAFFE \\ FIELD DIVISIONS IN JUNE 1944 \\ (continued)}

Army Group

1st Panzer Army

1st Hungarian Army

ARMY GROUP SOUTH UKRAINE
Divisions
208th Infantry
254th Infantry Division
349th Infantry Division
357th Infantry Division
359th Infantry Division
367th Infantry Division
371st Infantry Division
100th Jaeger Division
20th Hungarian Infantry Division
68th Infantry Division
101st Jaeger Division
16th Hungarian Infantry Division
18th Hungarian Reserve Infantry
Division
19th Hungarian Reserve Infantry
Division
24th Hungarian Infantry Division
25th Hungarian Infantry Division
27th Hungarian Infantry Division

153rd Field Training Division

1st Slovakian Infantry Division

8th Rumanian Infantry Division

Army Group General Dumitrescu 3rd Rumanian Army

9th Infantry Division 
TABLE XXI

GERMAN AND AXIS ORDER OF BATTLE IN THE EAST FOR INFANTRY, JAEGER, MOUNTAIN AND LUFTWAFFE FIELD DIVISIONS IN JUNE 1944

(continued)

Army Group

3rd Rumanian Army

6th Army

Army Group General Woehler 8th Army

Divisions

304th Infantry Division

2nd Rumanian Infantry Division

9th Rumanian Infantry Division

15th Rumanian Infantry Division

21st Rumanian Infantry Division

4th Rumanian Mountain Division

15th Infantry Division

17th Infantry Division

38th Infantry Division

62nd Infantry Division

106th Infantry Division

123rd Infantry Division

161st Infantry Division

257th Infantry Division

258th Infantry Division

282nd Infantry Division

293rd Infantry Division

294th Infantry Division

302nd Infantry Division

306th Infantry Division

320th Infantry Division

335th Infantry Division

355th Infantry Division

370th Infantry Division

384th Infantry Division

97th Jaeger Division

4th Mountain Division

14th Rumanian Infantry Division

79th Infantry Division

376th Infantry Division 


\section{TABLE XXI}

GERMAN AND AXIS ORDER OF BATTLE IN THE EAST FOR INFANTRY, JAEGER, MOUNTAIN AND LUFTWAFFE

FIELD DIVISIONS IN JUNE 1944

(continued)

Army Group

8th Army

4th Rumanian Army
Divisions

3rd Rumanian Infantry Division

5th Rumanian Infantry Division

11th Rumanian Infantry Division

46th Infantry Division

76th Infantry Division

198th Infantry Division

8th Jaeger Division

3rd Mountain Division

1st Rumanian "Guards" Division

1st Rumanian Infantry Division

4th Rumanian Infantry Division

5th Rumanian Infantry Division

6th Rumanian Infantry Division

7th Rumanian Infantry Division

8th Rumanian Infantry Division

13th Rumanian Infantry Division

20th Rumanian Infantry Division

18th Rumanian Mountain

Division

TOTAL DIVISIONS:

GERMAN DIVISIONS:

Infantry Divisions

Luftwaffe Field Divisions

130

Jaeger Divisions

4

7

Mountain Divisions

5

Total German Divisions

AXIS DIVISIONS

SLOVAKIA

Infantry Divisions

HUNGARY

Infantry Divisions 


\section{TABLE XXI}

\section{GERMAN AND AXIS ORDER OF BATTLE IN THE EAST FOR INFANTRY, JAEGER, MOUNTAIN AND LUFTWAFFE \\ FIELD DIVISIONS IN JUNE 1944 \\ (continued)}

Army Group

Divisions

\section{RUMANIA}

Infantry Divisions

Mountain Divisions

Total Axis Divisions

Total German and Axis Divisions
18

2

* Note Finnish military divisions have been omitted from table.

Source: Kurt Mehner, Die Geheimen Tagesberichte Der Deutschen Wehrmachtfuehrung Im Zweiten Weltkrieg 1939-1945 Vol. 10 (Osnabrueck: Biblio Verlag, 1985), pp. 502-504; lan V. Hogg, German Order of Battle 1944 (New York: Hippocrene Books Inc., 1975), pp. D2-D136; Samuel W. Mitchum, Jr. Hitler's Legions: The German Army Order of Battle. World War II (New York: Stein and Day Publishers, 1985), pp. 41473; Rolf Stoves, Die Gepanzerten und Motorisierten Deutschen Grossverbande 1935-1945 (Friedburg: PodzunPallas-Verlag GmbH, 1986), pp. 11-276; W. Victor Madej, German Army Order of Battle 1939-1945 Vols. I-II, Supplement (Allentown, Pennsylvania: Game Marketing Company, 1981); W. Victor Madej, Southeastern Europe Axis Armed Forces Order of Battle (Allentown, Pennsylvania: Game Marketing Company, 1982), pp. 26-46; Der Grosse Durchbruch bei Heeresgruppe Mitte Von 21.6. 10.8.44, National Archives Microfilm Publication T-78 Roll 136 . 


\section{CHAPTER VII}

\section{PRELUDE TO THE BELORUSSIAN SUMMER OFFENSIVE: THE WINTER BATTLES OF THE FOURTH ARMY \\ AND THIRD PANZER ARMY IN THE WINTER OF 1943-1944}

The Soviet High Command had attempted during the winter battles of 1943-1944 to push back the Belorussian salient occupied by Army Group Center without much success. Army Group Center had achieved for the most part a defensive success by the use of mobile reserves and a creative shifting of troops in the front lines along lateral roads and railways to prevent enemy breakthroughs. Therefore, the Soviet High Command was forced to adopt new tactics and a more coordinated offensive plan so as to prevent the German shifting of mobile reserves and army level reserves to prevent breakthroughs. The evolution of the operational planning for the Summer Belorussian Offensive stemmed from the previous Soviet failures to breakthrough Army Group Center's Belorussian salient in the winter battles of 19431944. An examination of the German 4th Army's defense of the Orsha-Mogilev sector and 3rd Panzer Army's protracted defense of the Vitebsk-Polotsk sector during the winter of 1943-1944 delineates the problem the Soviet High Command faced in trying to 
penetrate well prepared defensive positions backed up with mobile reserves.

\section{FOURTHARMY}

The German Command of Army Group Center anticipated a major Soviet offensive during November 1943 against the 4th Army. On November 4, 1943 the Kriegstagebuch of Army Group Center noted that all signs of a major enemy offensive were present in the 4th Army sector. ${ }^{1}$ The enemy was noted to have 22 Rifle Divisions, 1 Guard Tank Corps and 1 Artillery Corps concentrated in this sector (See Appendix B for Soviet corps, divisional, and non-divisional unit structures). ${ }^{2}$ The German order of battle on October 26, 1943 in the 4th Army sector contained roughly 16 divisions although some were not at their authorized strength (see Table XXII). Ten days later the long awaited offensive began along both sides of the river Dnieper and the autobahn in the 4th Army area (see Figure 34).

November 14,1943

The Soviets attacked after strong artillery preparation with 15 Rifle Divisions supported by numerous tanks. ${ }^{3}$ The German 4th Army had only 12 divisions in the 4th Army sector as of November 8, 1943 (see Table XXIII) to meet this attack. This attack achieved several breakthroughs which were liquidated in a counterattack. But the Soviets achieved two breakthroughs which resisted the 
German counterattacks at Kostjany and north of the autobahn at Nowoje Sselo. The Kostjany penetration was 3 kilometers wide and 2 kilometers deep extending into the German main battle line. ${ }^{4}$

November 15,1943

The Soviets continued their attack with heavy reinforcements but all attacks from Bobrowa to Kirijewo were repulsed. 5 The breakthrough position at Kostjany was sealed off and the position at Nowoje Sselo was reduced by the capture of the town. 6

November 16,1943

The Soviet attacks were repulsed and the breakthroughs moped up. Penetrations north of Guraki and Chandogi were thrown back in a counterattack. ${ }^{7}$ The enemy attacks in the area around Nowoje Sselo were defeated. The Kriegestagebuch of Army Group Center reflected that the German defensive success was achieved at the cost of high casualties and the situation was becoming strained as a result of German losses, enemy numerical superiority, and the continuous intensity of the tank attacks. ${ }^{8}$

\section{November 17,1943}

The Soviets renewed their battle along both sides of the Dnieper river in full strength with 30 Rifle Divisions and strongly massed tank forces. 9 The objective of the attack was to force a breakthrough at Orsha. The main concentration of the attack was 
against Nowoje Sselo which was lost in the course of the battle but in general all other attacks were repulsed.10 The Soviets lost 94 tanks in this attack before they were repulsed.11 The Headquarters of Army Group Center noted that despite the defensive victory achieved the loss of strength of German units and the exhaustion of the troops made the situation critical in the 4th Army sector. 12

November 18-21, 1943

The Soviets continued their major attack without success and they lost 31 tanks. ${ }^{13}$ Soviet attacks decreased in strength on November 19th and an attempted breakthrough in the XXVII Corps sector was defeated. ${ }^{14}$ On November 20th there was a general decrease in Soviet attacks and the German line was held. Major Soviet attacks ceased on November 21, 1943 after seven days of non-stop breakthrough attempts. The Kriegstagebuch of Army Group Center noted that the 4th Army had achieved a defensive success in the third Battle of the Smolensk Autobahn. ${ }^{15}$

\section{November 22-29, 1943}

A nine day lull settled in on the 4th Army sector. The Soviets launched local attacks against the front of the 337th Infantry Division in an attempt to prevent the breakthrough at Asarowa from being liquidated and the disengagement from the front by the 95th Infantry Division. ${ }^{16}$ However, by November 29th the Asarowa 
position had been cleared up and the 95th Infantry Division disengaged from the front.

\section{November 30,1943}

The fourth Battle of the Smolensk Autobahn commenced with the renewal of the major Soviet offensive against the left flank of the 4th Army east of Orsha. 17 The main concentration of effort was south of the Dnieper river and north of the Autobahn in the XXVII Corps sector. Despite considerable numerical superiority the Soviets were repulsed and only achieved a breakthrough position at Chandogi and Bobrowo in the 18th Panzer Grenadier Division's sector. ${ }^{18}$

\section{December 1. 1943}

The Soviets attacked along both sides of the Autobahn with 28 divisions in an attempt to breakthrough to Orsha. ${ }^{19}$ The Soviets failed to make a breakthrough toward Orsha and penetrations north of the Dnieper river were eliminated by German counterattack.

\section{December 2, 1943}

The Soviets resumed the attack on both sides of the Autobahn and the Dnieper river with 31 divisions. ${ }^{20}$ In the 18th Panzer Grenadier Division's sector the Soviets broke into Krassnaja Ssloboda. 21 In the sectors of the 78th Sturm Division and the 25th Panzer Grenadier Division all Soviet attacks were smashed.22 
December 3, 1943

The Soviets continued their offensive east of Orsha on both sides of the Autobahn. However, the Soviets lost Krassnajea Ssloboda to a counterattack by the 18th Panzer Grenadier Division.23 The 4th Army was achieving defensive success against Soviet attacks but the strength of the Army was reduced to 9 divisions as of December 3rd (see Table XXIV).

December 4, 1943

The Soviets ceased offensive operations after four days of offensive battles which resulted in high Soviet casualties and failure to breakthrough to Orsha.24 Army Group Center's Kriegstagebuch noted that the 4th Army had achieved a defensive victory in the 4th Battle of the Smolensk Highway. ${ }^{25}$ The Kriegstagebuch noted that the Soviets still had considerable tank forces which had not yet been employed in battle and that the enemy had probably not given up his objective of taking Orsha. ${ }^{26}$

December 14, 1943

Therefore, the 4th Army was reinforced as indicated by the December 14, 1943 order of battle (see Table XXV). The XXIII Corps was transferred from the 9th Army to the 4th Army. 


\section{THIRD PANZER ARMY}

The Third Panzer Army was in an extremely exposed position during the winter of 1943-1944. It was the northern most army in Army Group Center. One of the Soviet major goals of the 19431944 Winter Campaign was the routing of German forces at Vitebsk see Figures $35 \& 36$ ) 27 The German forces in the Third Panzer Army amounted to 8 Infantry Divisions, 4 Luftwaffe Field Divisions, and 1 Panzer Division (see Table XXVI). Severe battles were waged by the Soviets against the Third Panzer Army from December 13, 1943 to February 17, 1944. Despite tremendous Soviet pressure and some loss of ground the Third Panzer Army held Vitebsk and a line between Orsha in the southeast and Polotsk to the northwest (see Figure 37).

\section{December 11,1943}

The Kriegstagebuch of Army Group Center noted that the Soviets were prepared to attack from recognized concentration points along the front of Third Panzer Army. ${ }^{28}$

December 12,1943

Soviet reinforcements were reported to have arrived in the area east of Vitebsk. 29 


\section{December 13, 1943}

The major Soviet offensive commenced against the northeast front of the Third Panzer Army. 30 The numerically superior Soviet forces attacked the front of the 129th Infantry Division's sector in the Puljachi-Krizkije area (see Figure 38). ${ }^{31}$ The Soviets achieved a breakthrough onto the highway Pobki in the west. The attack between Bernewo and Tschernowo Lake was successful (see Figure 38). The northern bank of Tschernowo lake was reached on the right and the left attack group broke through in the direction of Wyrowljca (see Figure 38). ${ }^{32}$ The 20th Panzer Division in a counterattack brought the Soviet attack to a halt on the line Krelina-Chobnja-Jakuschenki-Radtschenki. 33

\section{December 14, 1943}

The IX Army Corps front was in danger of collapsing. The Soviets penetrated the front of the 129th Infantry Division at Puljachi and could not be repulsed till the Soviets had reached the intersection south of Wjasowki. ${ }^{34}$ The local command had exhausted its reserves placing the IX Army Corps in a critical situation. The following day the Soviets attacked the sectors of the 129th Infantry Division, 87th Infantry Division and the 20th Panzer Division. The Soviets enlarged the breakthrough from the northeast and southwest where the spearheads of their forces joined in the area of Bytschicha encircling the 87th Infantry Division and part of the 129th Infantry Division (see Figure 39). ${ }^{35}$ Both divisions were ordered to breakout to the southeast. The 
129th Infantry Division was pressed back to the hills south of Mechewoje where the counterattack of the 20th Panzer Division located in the town Malaschenki secured the hills south of Mechewoje. Soviet attacks were supported by an unusually high number of aircraft sorties which exceeded 1100.36

\section{December 16, 1943}

The Soviets succeeded in pinching off a large portion of the Nevel salient. The 129th Infantry Division withdrew along the line Dobrino-Mechowoje and the Soviets pursued the retreating Germans taking Dobrino, Mechowoje, and in the evening they occupied Bytschicha. ${ }^{37}$ The remnants of the 87th Infantry Division broke through the encirclement to Malaschenki (see Figure 40) on the same afternoon. ${ }^{38}$ The division had been reduced in strength to 5000-6000 men without heavy weapons and almost no vehicles. ${ }^{39}$ The 20th Panzer Division was able to hold their positions along the rail line stretching from Malaschenki to the Tschernowo lake (see Figure 40).

\section{December 17,1943}

The Soviets pushed back the 129th Infantry Division to the line Dobrino-Kleschowo-Schilakowo causing it to lose contact with the 6th Luftwaffe Field Division on its right flank. ${ }^{40}$ The 20th Panzer Division engaged in heavy battles along the rail line lost Schljuchi, Blochi, and Ambrossenki on the same day (see Figure 40). ${ }^{41}$ The crisis on this front even attracted the attention of 
Adolf Hitler and a Fuehrerbefehl was issued on December 17th allowing the Third Panzer Army to withdraw to the line Trofimenki-Tscherny-Wyschedki-Kusmino.42 The withdrawal of the IX Army Corps would free 1-2 divisions which could be used to strengthen the front while reserves were brought up to the area of Vitebsk-Polotsk. The 5th Jaeger Division and the 60th Panzer Grenadier Division were transfered to the 3rd Panzer Army area. ${ }^{43}$

\section{December 19,1943}

The Soviets shifted their attack to the northeast of Vitebsk against the right flank of the 14th Division between Borok and Wymno Lake achieving deep breakthroughs in five places (see Figure 41).44 The withdrawal of the LIII Army Corps on the night of December 18th resulted in the Soviets attacking the 6th Luftwaffe Field Division and breaking through to occupy part of the new main battle line northwest of Ssmolowka. The breakthrough east of the Tschernowo Lake could not be sealed off. The Soviets attempted to breakthrough on the road Surash-Vitebsk and to cross the road south of Bitowka with tank support. However, the Germans employed their last reserves and knocked out 60 Soviet tanks in the course of blocking the Soviet attack.45 Between Ssmolowka and the Koscho Lake all attacks were repulsed. A deep breakthrough on both sides of the Tschernowo Lake was repulsed. 


\section{December 20,1943}

During the night the 3rd Luftwaffe Field Division and the 129th Infantry Division were withdrawn under the cover of darkness to the Gorodok blocking position.

\section{December 21, 1943}

The Third Panzer Army was attacked from two sides. Heavy attacks were launched against the right flank of 14th Infantry Division, but despite Soviet pressure the road Vitebsk-Surash was cleared. The Soviets succeeded in breaking through the 3rd Luftwaffe Field Division's sector at Rudnja, Gribali and Lapuschnizy.46 A Soviet night attack brought about the loss of Wystawka, Mischutki and Karmolity which the Germans had just recaptured during the day.47 According to the Kriegstagebuch of Army Group Center, the Third Panzer Army had from December 1321, 1943 destroyed 247 Soviet tanks and 8 assault guns.48 The 14th Infantry Division was responsible for destroying 116 of the 247 Soviet tanks. 49

\section{December 23, 1943}

The Soviets shifted their attack to the southeast against the VI Army Corps. The attack was launched against the boundaries of the German 246th Infantry and 206th Infantry Divisions between the Liosno-Vitebsk road and the railroad (see Figure 42). 50 Despite a German counterattack with reserves the front remained torn open with a 1 kilometer gap opened by the Soviets. 51 The LIII Army 
Corps faced powerful Soviet attacks between Ssjubowowka and the Koscho Lake. The 3rd Luftwaffe Field Division and the 129th Infantry Division were pulled back from Gorodok (see Figure 42) while the Soviets continued an attack from the area north of Ssirotino.

\section{December 24, 1943}

The 3rd Panzer Army faced another day of crisis on the front. The Soviets ruptured the boundaries of the 246th and 206th Infantry Divisions and reached the Liosno-Vitebsk railroad and proceeded west and cut the vehicle road. 52 In the north Gorodok was given up by the 3rd Luftwaffe Field Division and the 129th Infantry Division. On the right flank of IX Army Corps the Soviets advanced on both sides of Filipenki on the road Vitebsk-Polotsk. The 20th Panzer Division in a counterattack blocked a Soviet advance on Ssirotino (see Figure 42). The Fuehrer ordered the withdrawal of the 14th Infantry Division to the Loswiza blocking position on the night of December 24-25.53 The 60th Panzer Grenadier Division "Feldherrnhalle" and the 5th Jaeger Division were released from Army Group Center reserve status and placed at the disposal of the 3rd Panzer Army to restore the situation southeast and northeast of Vitebsk (see Figure 42).

\section{December 25. 1943}

The "Feldherrnhalle" Panzer Grenadier Division prevented a deep breakthrough on the right flank of the 246th Infantry Division 
on Christmas day thereby momentarily stabilizing the southeastern front. 54 The 6th Luftwaffe Field Division lost Grabniza and a hole was punched through the inner flanks of the LIII and IX Corps which permitted the Soviets to cross the road Vitebsk-Ssirotino to the south (see Figure 42).55 The right flank of the IX Army Corps was pressed back clinging to both sides of the Gorodok-Ssirotino road up to the town Igumenschtschina.

\section{December 26, 1943}

The critical situation on the northern flank of the 3rd Panzer Army caused the Army High Command OKH to transfer the 16th Panzer Division from the south flank of the 9th Army to the 3rd Panzer Army. 56 The Soviets achieved a deep breakthrough south of Duena and rolled up the front line to the "Bear Position" located on left flank of the 14th Infantry Division and the right flank of the 4th Luftwaffe Field Division. 57 The Soviets widened their breakthrough in the southeast by collapsing the right flank of the 6th Luftwaffe Field Division so that it had to withdraw to the edge of the woods south of Ssilki.58 The 3rd Panzer Army despite continued Soviet pressure contained the Soviet attacks with its new reinforcements (see Table XXVII).

\section{December 27-28, 1943}

German intelligence noted the Soviet strength in the area of Vitebsk to be 42 Rifle Divisions, 2 Rifle Brigades, 15 Tank Brigades, 4 Tank Regiments, and 4 Mechanized Brigades. 59 The 
Soviets continued to attempt a breakthrough between the vehicle road and the Liosno-Vitebsk road (see Figure 43). A counterattack by the Panzer Grenadier Division "Feldherrnhalle" repulsed the Soviet breakthrough group at Roshnowo and threw it back over the railroad track. A breakthrough into the main battle line of the 206th Infantry Division was cleared up by deployment of the last reserves. The Soviets achieved a penetration through the occupation of the strong points in the main battle line of the 129th Infantry Division and the 6th Luftwaffe Field Division in the wooded terrain southeast of Zygany. The 5th Jaeger Division was tied down by a Soviet attack in the flank at Masurino.

The Panzer Grenadier Division "Feldherrnhalle" threw the Soviets back across the vehicle road and retook the controlling hill 219.6.60 In the sector of the 129th Infantry Division and the 6th . Luftwaffe Field Division the Soviets penetrated the wooded terrain to the west bank of the Loswiza Lakes. The road had to be cleared from the village Losswida to the south so parts of the 129th Infantry Division could be withdrawn to a new defensive position.

\section{December 29, 1943}

All Soviet attacks against the LIII and IX Army Corps were repulsed. The 3rd Panzer Army from December 13-19, 1943 had destroyed 520 Soviet tanks, disabled 29 tanks, and captured 2 tanks. 61 
December 30. 1943

The focal points of the defensive battle of Vitebsk continued to be in the breakthrough areas southeast and northeast of the city. The Soviets attacked on a wide front against the northern front of the 246th Infantry Division, Panzer Grenadier Division "Feldherrnhalle," and the right right flank of the 206th Infantry Division. The Soviets broke through between Dymanowo and Roshnowo to the vehicle road.62 In the afternoon the road was finally cleared by the counterattacks of the last reserves with assault guns. A breakthrough toward Gribuny was blocked by a counterattack.

December 31, 1943

The Germans made further progress in a counterattack by the Panzer Grenadier Division "Feldherrnhalle" supported by reinforcements from the 4th Army in pressing the Soviets further back to the East away from the vehicle road (see Figure 44). The Soviet attack between Loswiza Lake and the road Vitebsk-Polotsk was repulsed.63 The 5th Jaeger Division on the right flank of the IX Army Corps gained control of the hills southeast of Tschisti bringing the Soviet penetration area up to Saronowskoje Lake under fire by German guns (see Figure 44).

January 1-8, 1944

On January 1, 1944, the Soviets cut the vehicle road southeast of Vitebsk and held onto a stretch of the road through 
January 2nd.64 Northwest of Vitebsk the Soviets captured Jermatschki on January 3rd. Between January 4-6, 1944 the Soviets attempted breakthroughs to the southeast and northwest of Vitebsk which were thrown back in German counterattacks (see Figure 45). On January 5th 42 Soviet tanks were destroyed.65 On January 7,1944 , the main offensive of the Soviet forces shifted to the northwest of Vitebsk between Loswiza and Saranowskoje Lake. The Soviets achieved success against the 206th Infantry Division and captured Lushino, Saranowskoje Lakes and Sslobodka.66 The Soviet attack on January 8th achieved a breakthrough in the wooded area north of Kossatschi which crossed over the vehicle road to Makarowo and proceeded on to Lutschessa and Perewos. On this day Soviet tank losses amounted to 159.67

\section{January 11,1944}

The Germans launched a major counterattack to recapture the vehicle road which was only partly successful (see Figure 46). The 299th Infantry Division lead the counterattack and recaptured Makarowo and the 131st Infantry Division retook Majaklowo (see Figure 46). 68 According to the Kriegstagebuch of Army Group Center 945 Soviet tanks were destroyed and 74 disabled in the 3rd Panzer Army area from December 13, 1943 to January 11, 1944.69

\section{January 12, 1944}

German counterattacks in the southwest and to the west of the vehicle road attained an improvement in the front. The 299th 
Infantry Division's counterattack reached the high terrain east of the line Makarowo-Mjaklowo in the evening. The Soviets attacked northwest of Vitebsk with 6 divisions and 2 tank brigades (see Appendix B) along both sides of the Vitebsk-Ssirotino road but did not achieved success. ${ }^{70}$ The Germans destroyed 43 Soviet tanks in the course of the day on the 3rd Panzer Army Front. 71

\section{January 13. 1944}

The Soviets launched a counterattack against the 299th Infantry Division in the sector of Makarowo-Mjaklowo. The hills northwest of Makarowo were lost in the 12th Infantry Division's sector and the Soviets occupied the isthmus on the south end of the Saranowskoje Lake. 72

\section{January 14,1944}

The 12th Infantry Division pushed back the Soviets and reoccupied the isthmus on the south end of the Saranowskoje Lake. ${ }^{73}$ On the southeast front the Soviets attempted to envelope Kartaschewa by an attack against the front of the 246th Infantry Division and the right flank of the 131st Infantry Division. ${ }^{74}$

\section{January 15,1944}

Soviet attacks to the northwest of Vitebsk subsided. However, Soviet attacks continued to the southeast against the 246th Infantry Division. The Soviets acquired the woods southeast 
of Krjukowo and both sides of the communication road with a penetration to hill Souch. Krynki.

January 16, 1944

The northwest front of the 3rd Panzer Army remained quiet, but the Soviets pressed their attack in the southeast with numerous tank formations. The focal point of the attack remained the 246th Infantry Division. The Soviets widened their penetrations and acquired both sides sides of the communication road and occupied the railroad station Krynki. ${ }^{75}$ The Soviets tore a hole in the front which the Germans could not close until evening.

\section{January 17. 1944}

The sector northwest of Vitebsk remained quiet while the Soviet offensive continued southeast of Vitebsk (see Figure 47). The Soviet attack at Kryukowo was repulsed, but a hole was achieved in the front southwest of the railroad station Krynki. 76 The Soviets broke through to Tscherkassy, but were thrown back by a German counterattack which knocked out 36 Soviet tanks and restored the situation. ${ }^{77}$

January 18, 1944

The Kriegstagebuch of Army Group Center noted that the first phase of the Battle of Vitebsk appeared to be finished.78 The only further Soviet offensive activity was an attempt to push back the front of the 246th Infantry Division to the south. 
January 23, 1944

The Soviet resumed offensive operations on the southeast front after a five day pause. The 246th Infantry Division received the brunt of the Soviet attack and the Soviets broke through south of Krynki. The attack reached the woods northeast of Schugajewo.

\section{February 2. 1944}

The 3rd Panzer Army Front had remained quiet for almost one week when the Soviets resumed offensive operations. The 87th and 12th Infantry Divisions were attacked after a 30 minute artillery preparation by 6 Soviet divisions on a 12 kilometer wide front. 79 The Germans repelled the attack inflicting heavy losses on the Soviets.

\section{February 3.1944}

The Soviet offensive against Vitebsk was resumed in full strength. Heavy artillery preparation preceded the Soviet attack against the front of the 299th, 131st, and the right flank of the 206th Infantry Division (see Figure 48). 80 The Soviets achieved numerous breakthroughs in the German defensive positions (see Figure 48). German units were surrounded and forced to conduct a defense from all sides. German counterattacks achieved only limited success and both sides suffered heavy losses. The Soviet attack northwest of Vitebsk was preceded by a 2 hour 30 minute artillery preparation. The Soviets attacked with 10 divisions supported by tanks against the LIII Army Corps (see Figure 48).81 
In extremely bitter battles the Soviets broke through the German defensive positions and captured the rail line.82 The Germans threw in all available reserves to form a makeshift defensive front in the secondary positions during the afternoon. The Soviets occupied the railroad to the south with the support of 20 tanks.

\section{February $4-17,1944$}

German counterattacks finally gained momentum and halted the Soviet breakthroughs southeast and northwest of Vitebsk. All further enemy attacks were repulsed and all breakthroughs were liquidated by German counterattacks along the 3rd Panzer Army's Front (see Figure 49). On February 17, 1944 the second Battle of Vitebsk ended in an outstanding defensive success for the 3rd Panzer Army. ${ }^{83}$ The Soviets had recklessly employed 6 armies with a total of 53 infantry divisions and 13 tank brigades with strong artillery support to breakthrough from the southeast and northwest of Vitebsk to destroy the German divisions in "Fortress Vitebsk." 84 The Soviets not only failed to choke off and destroy the German forces in Vitebsk, but they also failed to sever the railroad line Orsha-Vitebsk and the road between Vitebsk and Lepel. The cost of the Soviet defeat in the second Battle of Vitebsk from February 317, 1944 was tabulated as the following: 832 prisoners; 68 deserters; 352 tanks destroyed; 31 tanks immobilized; 24 artillery pieces captured; 15 mortars captured; 266 machine guns captured; and 40 Soviet aircraft shot down. 85 


\section{SOVIET RESOURCES AND STRATEGY IN THE}

WINTER BATTLES OF 1943-1944

The Soviets continued attacks intermittently till March 29, 1944 when the Soviets finally went over to the defensive. Soviet attacks had failed in the 4th Army and 3rd Panzer Army areas because of a lack of resources, concentration of forces and coordination. The 1st Baltic Front consisting of the 4th Shock, 11th Guards, 39th, 43rd, 51st Armies and the 3rd Air Army had operated against the Vitebsk area.86 The Western Front contained the 5th, 10th, 31st, 33rd, 49th, 50th, 61st, 63rd, 65th Armies and the 1st Air Army which had operated against the Orsha area.87

Both of these fronts, however, did not receive the same quantity of reinforcements, artillery and tanks as the fronts operating in the Leningrad and Ukraine sectors. ${ }^{88}$ According to Soviet sources the 1st Baltic Front, the Western Front and the Belorussian Front received only $19 \%$ of all reserve reinforcements, $26 \%$ of all guns and mortars, and only $4.2 \%$ of the tanks and assault guns. 89 The Western Front had failed to take Orsha in the November and December 1943 winter battles. The 1st Baltic Front attempted to seize Vitebsk by the employment of the 4th Shock, 11th Guards, 43rd and 39th Armies. ${ }^{90}$ However, the Soviets failed to take Vitebsk with the 1st Baltic Front and the battle that had begun on December 13, 1943 ended on January 18, 1944. The Soviets eliminated the Nevel salient northwest of Vitebsk. But the 
tenacity of the 3rd Panzer Army in holding Vitebsk required the Soviets to change their strategy.

The Soviets tried to take Vitebsk by employing two fronts against the 3rd Panzer Army. The 39th Army was transferred from the 1st Baltic Front to the Western Front. On February 3, 1944, the Battle for Vitebsk resumed with the 1st Baltic Front attacking northwest and the Western Front attacking southwest of Vitebsk. This offensive continued until February 17, 1944 when Soviet operations subsided. The Soviets had failed to take Vitebsk, but they had cut the Vitebsk-Orsha highway to the south of the city and the Vitebsk-Ssirotino road to the northwest of Vitebsk (see Figure 50). 91 Thus, the Soviets were faced with the problem of overcoming the fortified, entrenched, defensive positions of Army Group Center during the Summer of 1944. Soviet strategy and tactics in the planning of the Belorussian summer offensive were shaped as a result of the Soviet failures on the Central Front.

\section{GERMAN DEFENSIVE STRATEGY}

The Germans were for the most part tied to a system of defense in place which worked during the winter of 1943-1944 with the use of mobile reserves and the shifting of forces. German mobile reserves consisted of panzer units, assault gun battalions, and motorized antitank units (see Appendix A). 92 Artillery and rocket projector regiments were also made available to meet 
Soviet attacks (see Appendix A). The shifting of German forces to the focal point of the Soviet attacks occurred on a battalion by battalion basis. When Soviet attacks were at full intensity the Germans transferred up to two battalions per day from an individual division in the army area.93 During the night one or two battalions were pulled out and the adjacent sectors extended. These battalion sectors were extended each night as another one or two battalions were withdrawn until the entire division was withdrawn to the threatened sector. 94 The Germans maintained their divisional integrity by this method rather then transferring single battalions from different divisions. 95 However, when the Soviet pressure was at its peak it was often necessary to pull several battalions from several divisions at once temporarily causing mixing of divisions until divisional integrity could be restored. 96 The Germans achieved remarkable results using these defensive tactics. In the 4th Army area the Germans consistently defeated numerically superior Soviet forces that outnumbered them by a $10: 1$ ratio. 97

The Commander of the 4th Army General Heinrici attributed his defensive success to three factors:

In my opinion, there were three main factors that contributed to the success of the defense. First, I formed narrow divisionsal sectors, with a high ratio of force to space, on the actual frontage of the Russian assault. Secondly, I managed to form a very powerful artillery grouping, of 380 guns, to cover the threatened sector. This was controlled by a single commander, at Army Headquarters, and was able to concentrate its 
fire on any required point of that 20 kilometer frontage.

The Russian offensives were supported by up to a thousand guns, but their fire was not so concentrated. Thirdly, the losses of the German divisions engaged-which had to be reckoned as the equivalent of about one battalion per division in each day of battle--were compensated by a system of drawing battalions from divisions on other parts of the Army front. I always tried to have three fresh battalions--one for each of the divisions holding the battle front--ready behind this before the attack started. The other battalion of the regiment from which it was drawn would follow, together with the regimental staff, and in this way 1 would get complete fresh regiments incorporated in the front, and then complete fresh divisions. The temporary mixing of divisions was inevitable, and part of the price of the defensive success, but I always tried to restore their integrity as soon as possible. 98

\section{SOVIET TACTICAL FAILURES}

A more creative Soviet plan of attack would have overcome such German defensive tactics by diversionary attacks against the critically extended sectors of the front outside of the main area of attack. The Soviets could also have shifted their attacks from one area to another area causing confusion for the German High Command. Instead, the Soviets in the winter battles of 1943-1944 in Belorussia most often renewed their attacks at the identical spot where they had attacked previously. 99 Soviet artillery was extremely effective on the first day of offensive operations, but after a breakthrough had been achieved the use of artillery became very disorganized and disjointed. 100 Troops in the breakthrough 
zone were deprived of effective artillery support which caused them to be more susceptible to German counterattack. These Soviet weaknesses were to be corrected in the Belorussian Summer Campaign of 1944. 


\section{TABLE XXII}

GERMAN 4TH ARMY ORDER OF BATTLE, OCTOBER 26, 1943

Army Corps

4th Army Reserve

XII Corps

XXXIX Panzer Corps

XXVII Corps

Army Group Center Reserve
Formations

286th Security Division

KG 35th Infantry Division

KG 56th Infantry Division

262nd Infantry Division

330th Infantry Division

342th Infantry Division

25th Panzer Grenadier Division

95th Infantry Division

KG 113 Infantry Division

252nd Infantry Division

337th Infantry Division

18th Panzer Grenadier Division

26th Infantry Division

52nd Infantry Division

KG 78th Assault Division

197th Infantry Division

1st SS Motorized Brigade

Cavalry Regiment

*See Appendix A for German Divisional and Non-Divisional Unit Structures.

Source: Kurt Mehner, Die Geheimen Tagesberichte Der Deutschen Wehrmachtfuehrung Im Zweiten Weltkrieg 1939-1945 Vol. 8 (Osnabrueck: Biblio Verlag, 1988), p. 582. 


\section{TABLE XXIII}

\section{GERMAN 4TH ARMY ORDER OF BATTLE,} NOVEMBER 8, 1943

Army Corps

4th Army Reserve

XII Corps

XXXIX Panzer Corps

XXVII Corps
Formations

286th Security Division

Corps Detachment D: 56th

Infantry Division and 262nd

Infantry Division

KG 35th Infantry Division

342nd Infantry Division

26th Infantry Division

95th Infantry Division

337th Infantry Division

18th Panzer Grenadier Division

25th Panzer Grenadier Division

78th Assault Division

197th Infantry Division

1st SS Motorized Brigade

*See Appendix A for German Divisional and Non-Divisional Unit Structures.

Source: Kurt Mehner, Die Geheimen Tagesberichte Der Deutschen Wehrmachtfuehrung Im Zweiten Weltkrieg 1939-1945 Vol. 8 (Osnabrueck: Biblio Verlag, 1988), p. 586. 


\section{TABLE XXIV}

GERMAN 4TH ARMY ORDER OF BATTLE, DECEMBER 3, 1943

Army Corps

4th Army Reserve

XII Corps

XXXIX Panzer Corps

XXVII Corps
Formations

286th Security Division

KG 35th Infantry Division

342nd Infantry Division

26th Infantry Division

337th Infantry Division

18th Panzer Grenadier Division

25th Panzer Grenadier Division

78th Assault Division

197th Infantry Division

"See Appendix A for German Divisional and Non-Divisional Unit Structures.

Source: Kurt Mehner, Die Geheimen Tagesberichte Der Deutschen Wehrmachtfuehrung Im Zweiten Weltkrieg 1939-1945 Vol. 9 (Osnabrueck: Biblio Verlag, 1988), p. 501. 
TABLE XXV

GERMAN 4TH ARMY ORDER OF BATTLE, DECEMBER 14, 1943

Army Corps

4th Army Reserve

XXIII Corps

XII Corps

XXXIX Panzer Corps

XXVII Corps
Formations

286th Security Division

95th Infantry Division

110th Infantry Division

131st Infantry Division

260th Infantry Division

267th Infantry Division

Corps Detachment D: 56th and 262nd Infantry Division 35th Infantry Division 342nd Infantry Division 18th Panzer Grenadier Division 26th Infantry Division 337th Infantry Division 25th Panzer Grenadier Division 78th Assault Division 197th Infantry Division

"See Appendix A for German Divisional and Non-Divisional Unit Structures.

Source: Kurt Mehner, Die Geheimen Tagesberichte Der Deutschen Wehrmachtfuehrung Im Zweiten Weltkrieg 1939-1945 Vol. 9 (Osnabrueck: Biblio Verlag, 1988), p. 505. 
TABLE XXVI

GERMAN 3rd PANZER ARMY ORDER OF BATTLE, DECEMBER 14, 1943

Army Corps

3rd Panzer Army Reserve

IX Corps

LIII Corps

VI Corps
Formations

201st Security Division

2nd Luftwaffe Field Division

6th Luftwaffe Field Division

20th Panzer Division

87th Infantry Division

129th Infantry Division

252nd Infantry Division

3rd Luftwaffe Field Division

4th Luftwaffe Field Division

14th Infantry Division

206th Infantry Division

211th Infantry Division

246th Infantry Division

256th Infantry Division

*See Appendix A for German Divisional and Non-Divisional Unit Structures.

Source: Kurt Mehner, Die Geheimen Tagesberichte Der Deutschen Wehrmachtfuehrung Im Zweiten Weltkrieg 1939-1945 Vol. 9 (Osnabrueck: Biblio Verlag, 1988), p. 505. 


\section{TABLE XXVII}

GERMAN 3RD PANZER ARMY ORDER OF BATTLE, DECEMBER 26, 1943

Army Corps

3rd Panzer Army Reserve

IX Corps

LIII Corps

VI Corps
Formations

201st Security Division

5th Jaeger Division

20th Panzer Division

87th Infantry Division

2nd Luftwaffe Field Division

3rd Luftwaffe Field Division

6th Luftwaffe Field Division

129th Infantry Division

252nd Infantry Division

4th Luftwaffe Field Division

14th Infantry Division

60th Panzer Grenadier Division

"Feldherrnhalle"

197th Infantry Division

206th Infantry Division

211th Infantry Division

246th Infantry Division

256th Infantry Division

`See Appendix A for German Divisional and Non-Divisional Unit Structures.

Source: Kurt Mehner, Die Geheimen Tagesberichte Der Deutschen Wehrmachtfuehrung Im Zweiten Weltkrieg 1939-1945 Vol. 9 (Osnabrueck: Biblio Verlag, 1988), p. 509. 


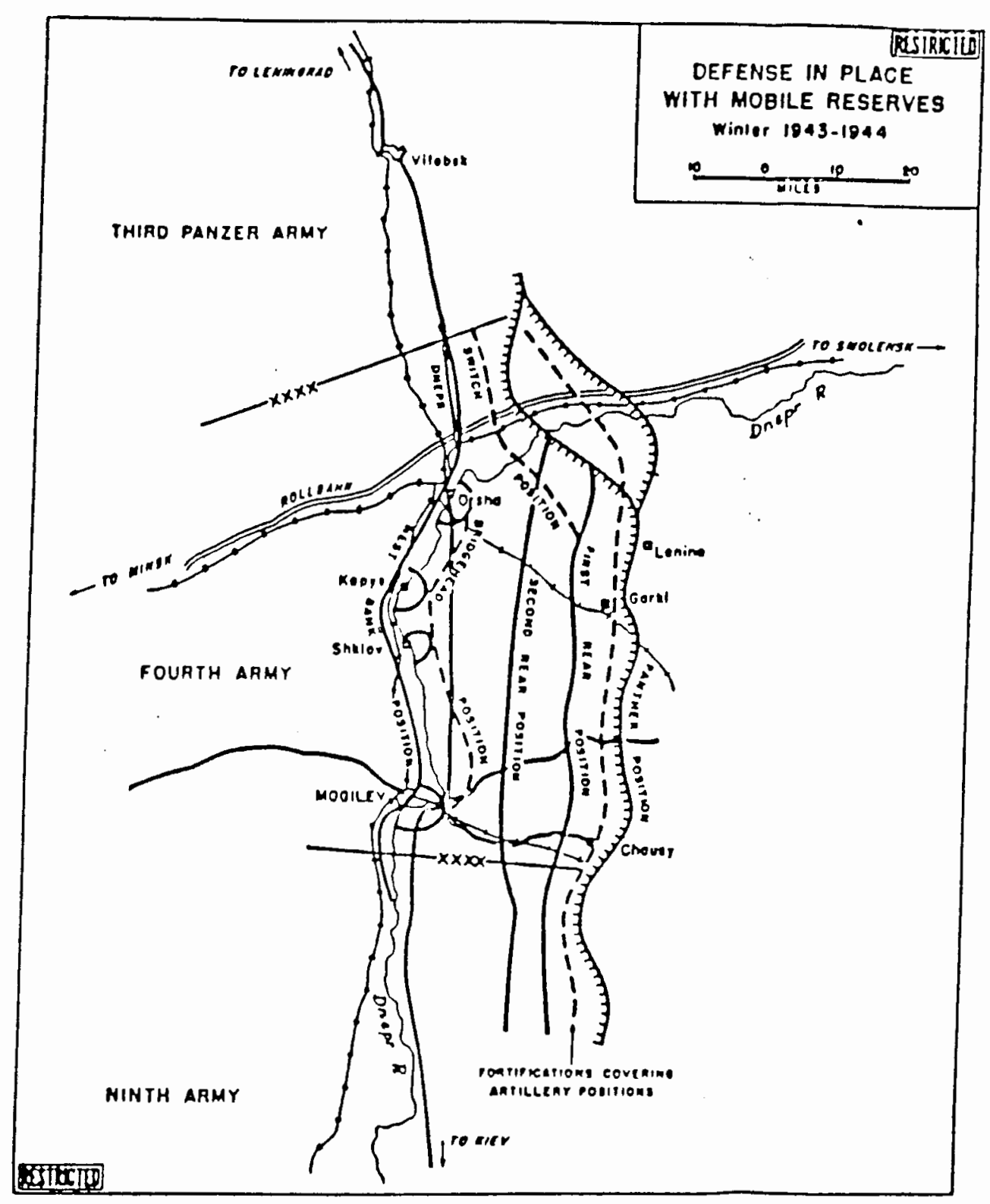

Figure 34. German Defense In Place With Mobile Reserves: Winter 1943-1944. Source: Department of the Army, German Defense Tactics Against Russian Break-Throughs (Washington D.C.: Department of the Army, October, 1951), Map No. 6. 


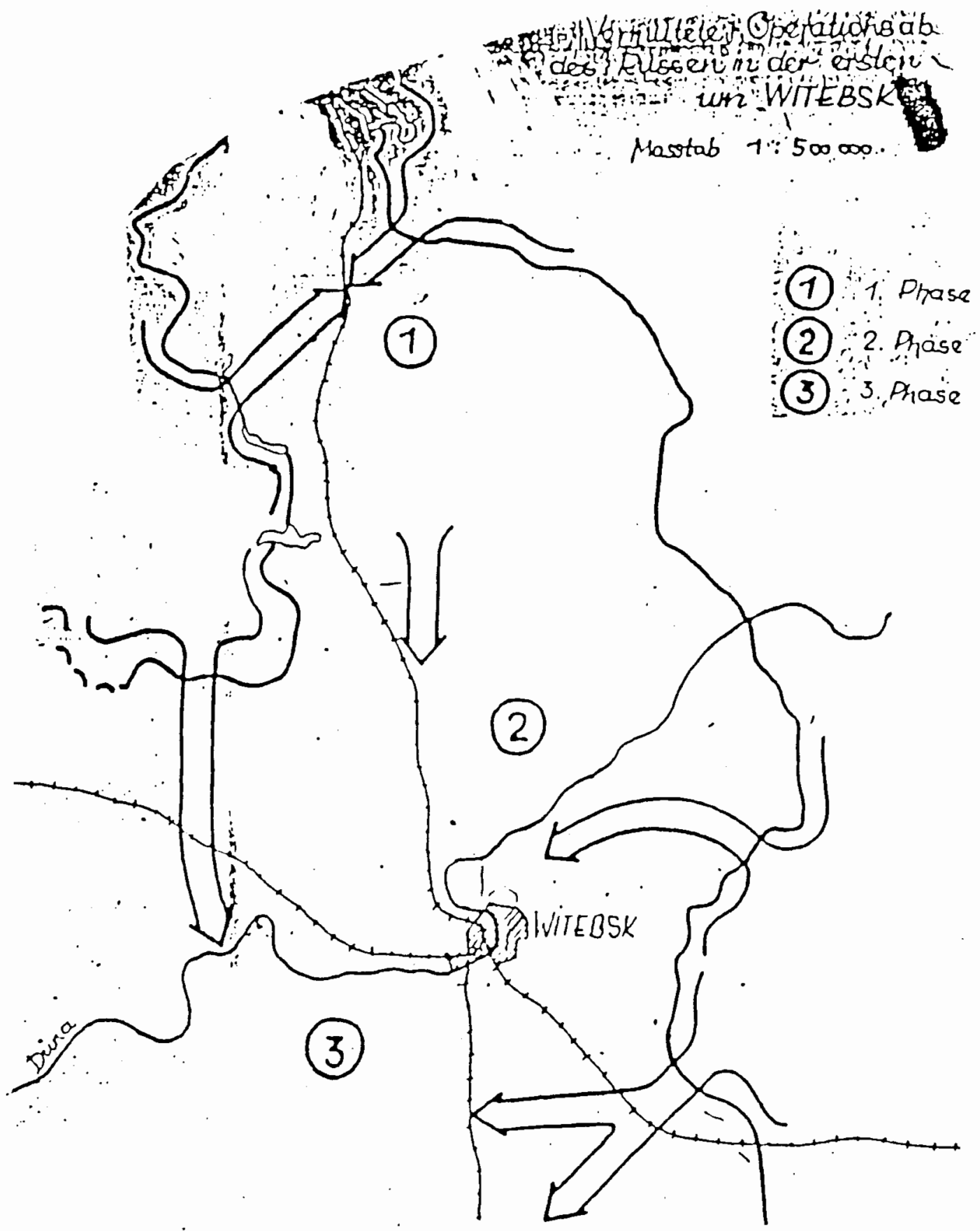

Figure 35. Probable Russian Operational Objectives in the First Battle of Vitebsk. Source: Pz.A.O.K. 3, Die Abwehrschlachten um Witebsk vom 13.12.43 bis 17.2.44. National Archives Microfilm Publication T-313 Roll 291. 


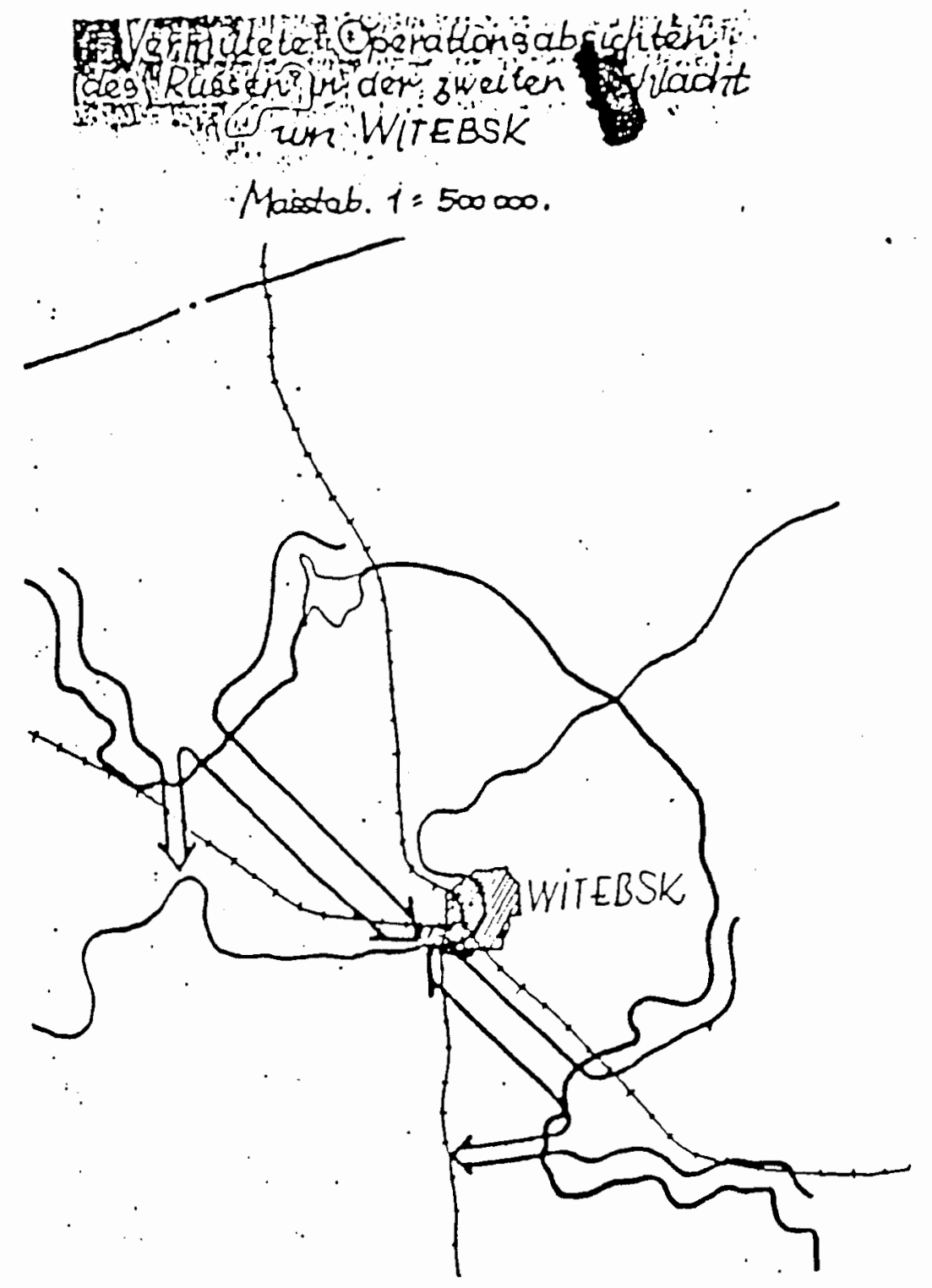

Figure 36. Probable Russian Operational Objectives in the Second Battle of Vitebsk. Source: Pz.A.O.K. 3, Die Abwehrschlachten um Witebsk vom 13.12.43 bis 17.2.44. National Archives Microfilm Publication T-313 Roll 291. 


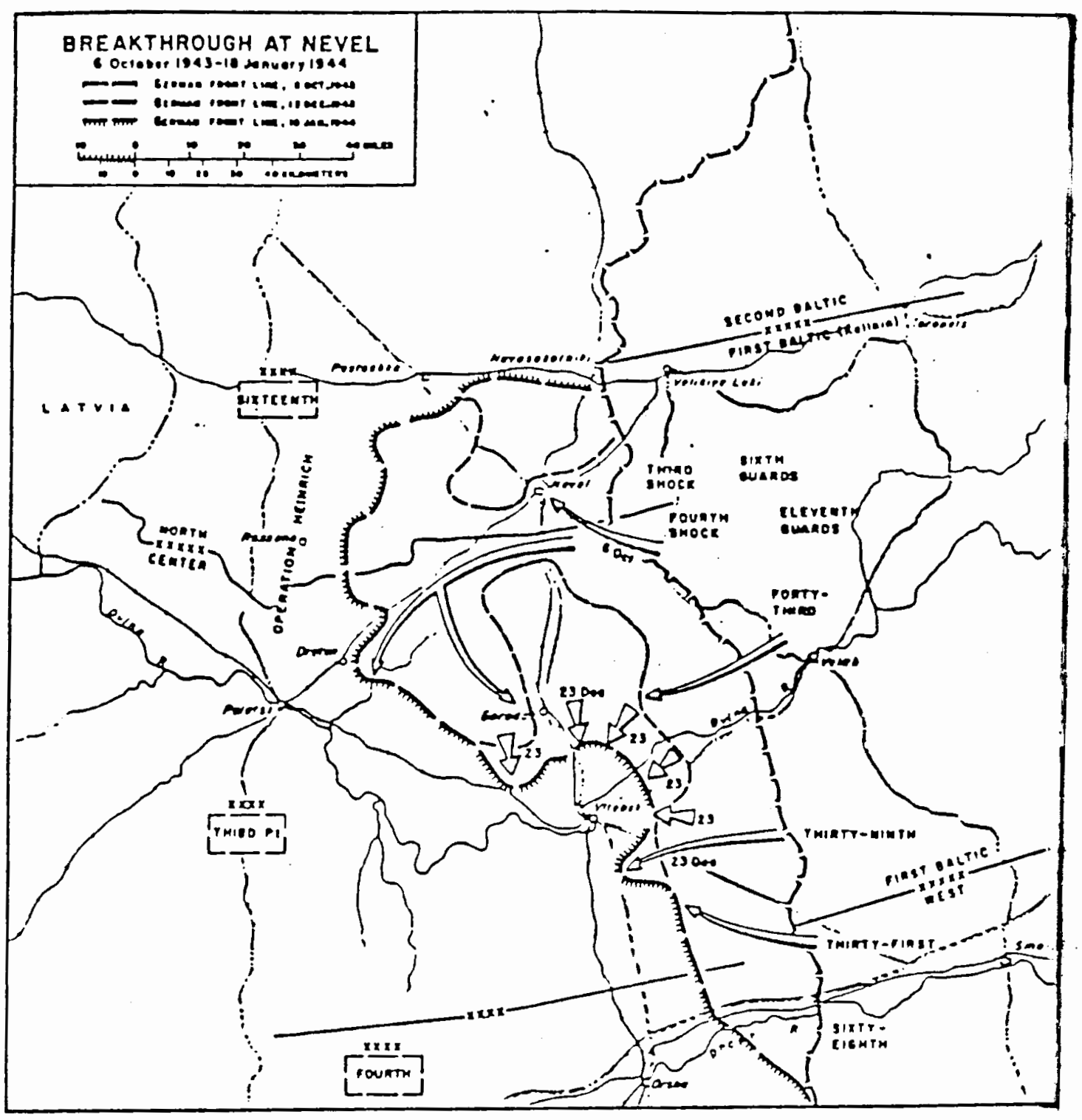

Figure 37. Breakthrough At Nevel. Source: Earl F. Ziemke, Stalingrad To Berlin: The German Defeat In The East (New York: Dorset Press, 1968), p. 198. 


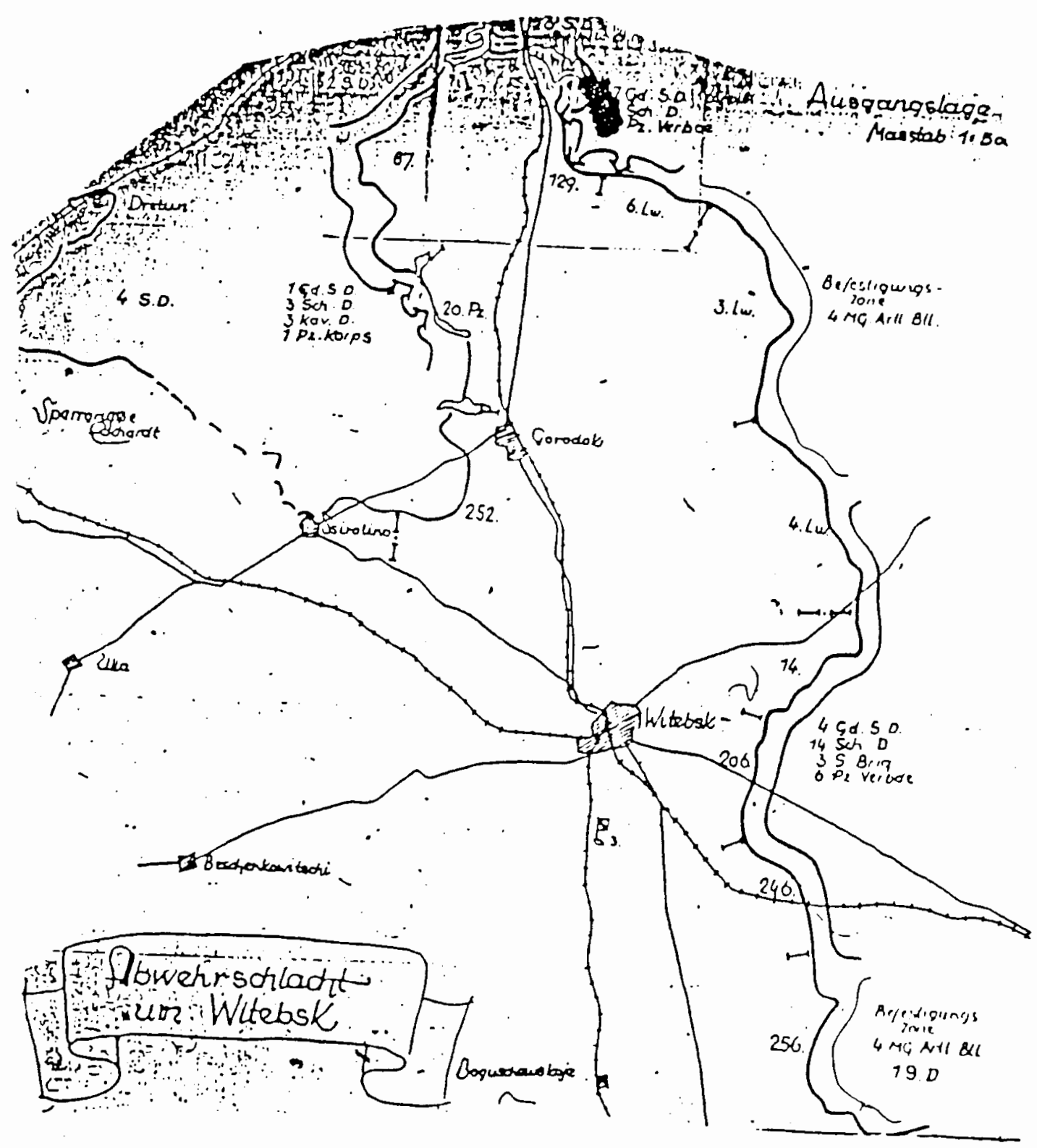

Figure 38. Battle of Vitebsk, December 13, 1943. Source: Pz.A.O.K. 3, Die Abwehrschlachten um Witebsk vom 13.12.43 bis 17.2.44. National Archives Microfilm Publication T-313 Roll 291. 


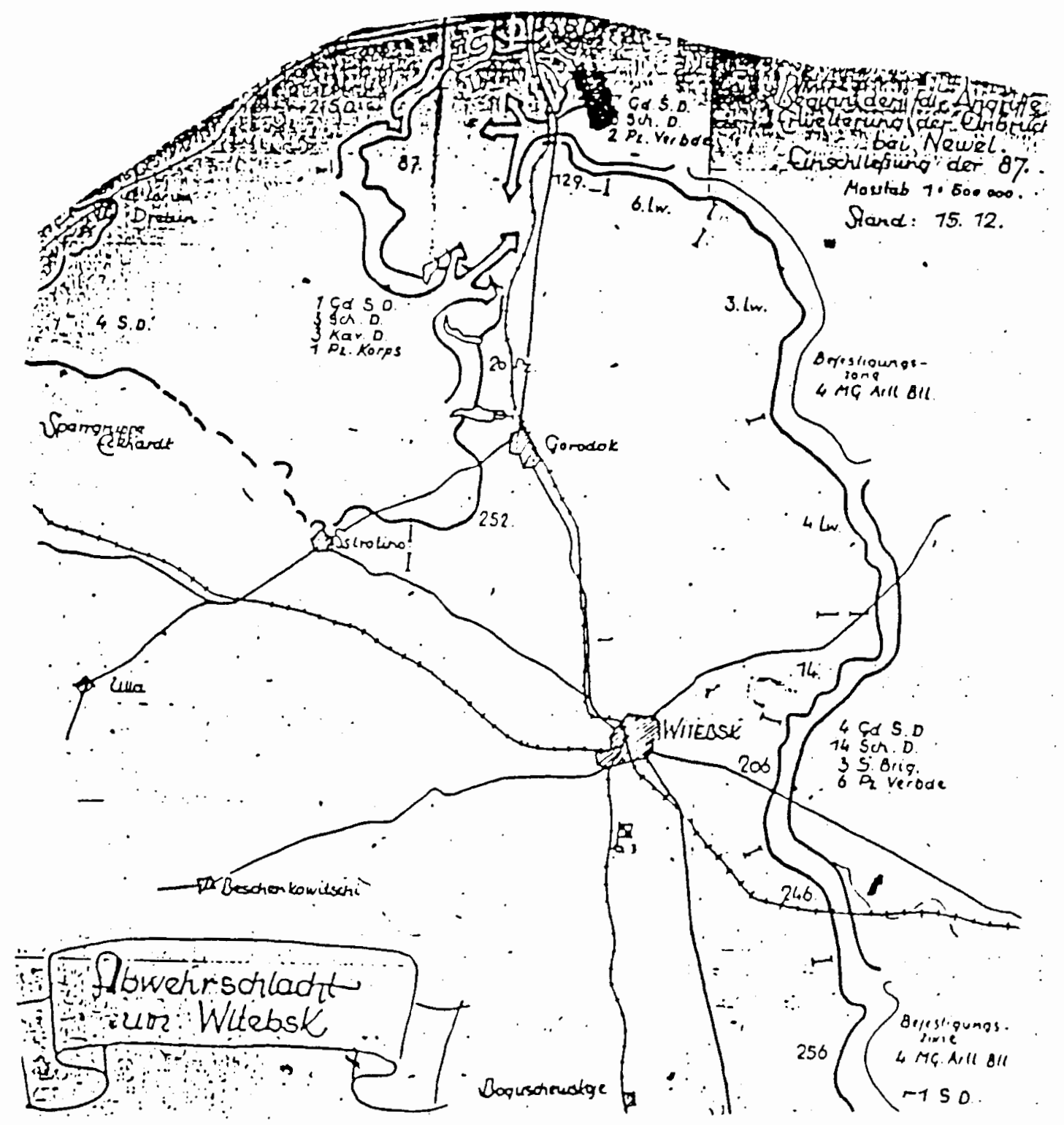

Figure 39. Battle of Vitebsk, December 15, 1943.

Source: Pz.A.O.K. 3, Die Abwehrschlachten um Witebsk vom 13.12.43 bis 17.2.44. National Archives Microfilm Publication T-313 Roll 291. 


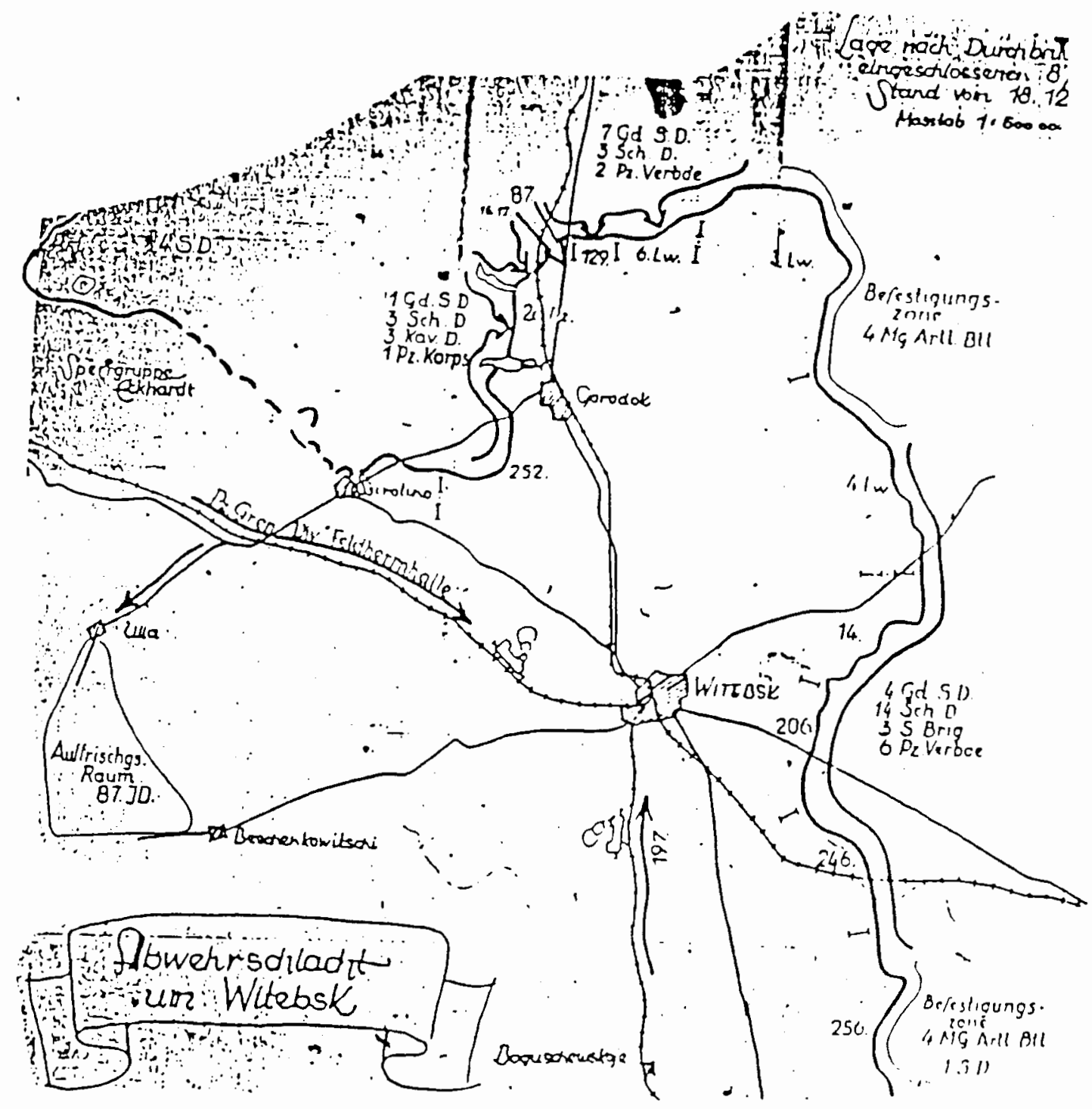

Figure 40. Battle of Vitebsk, December 18, 1943. Source: Pz.A.O.K. 3, Die Abwehrschlachten um Witebsk vom 13.12.43 bis 17.2.44. National Archives Microfilm Publication T-313 Roll 291. 


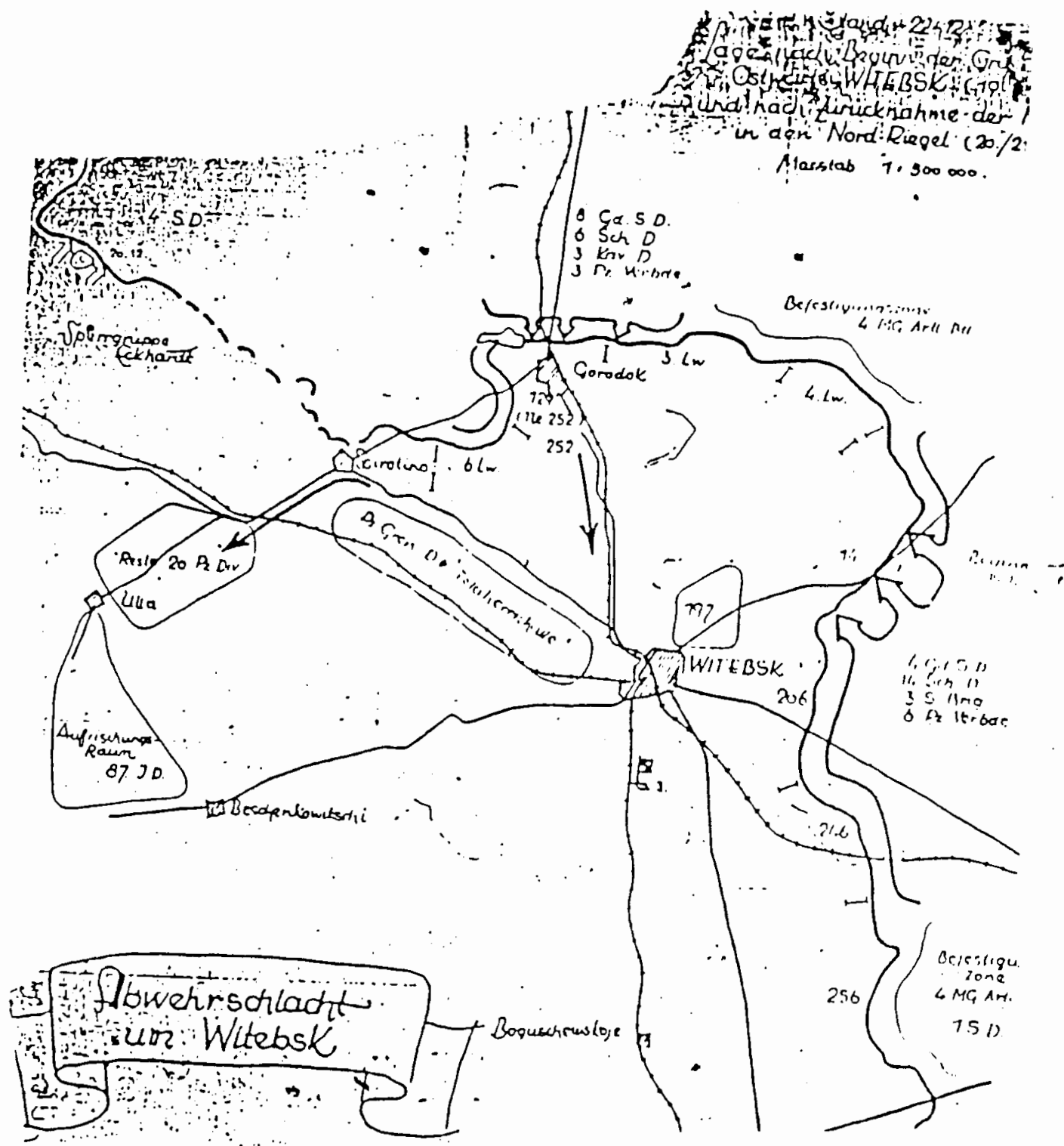

Figure 41. Battle of Vitebsk, December 19-22, 1943. Source: Pz.A.O.K. 3, Die Abwehrschlachten um Witebsk vom 13.12.43 bis 17.2.44. National Archives Microfilm Publication T-313 Roll 291. 


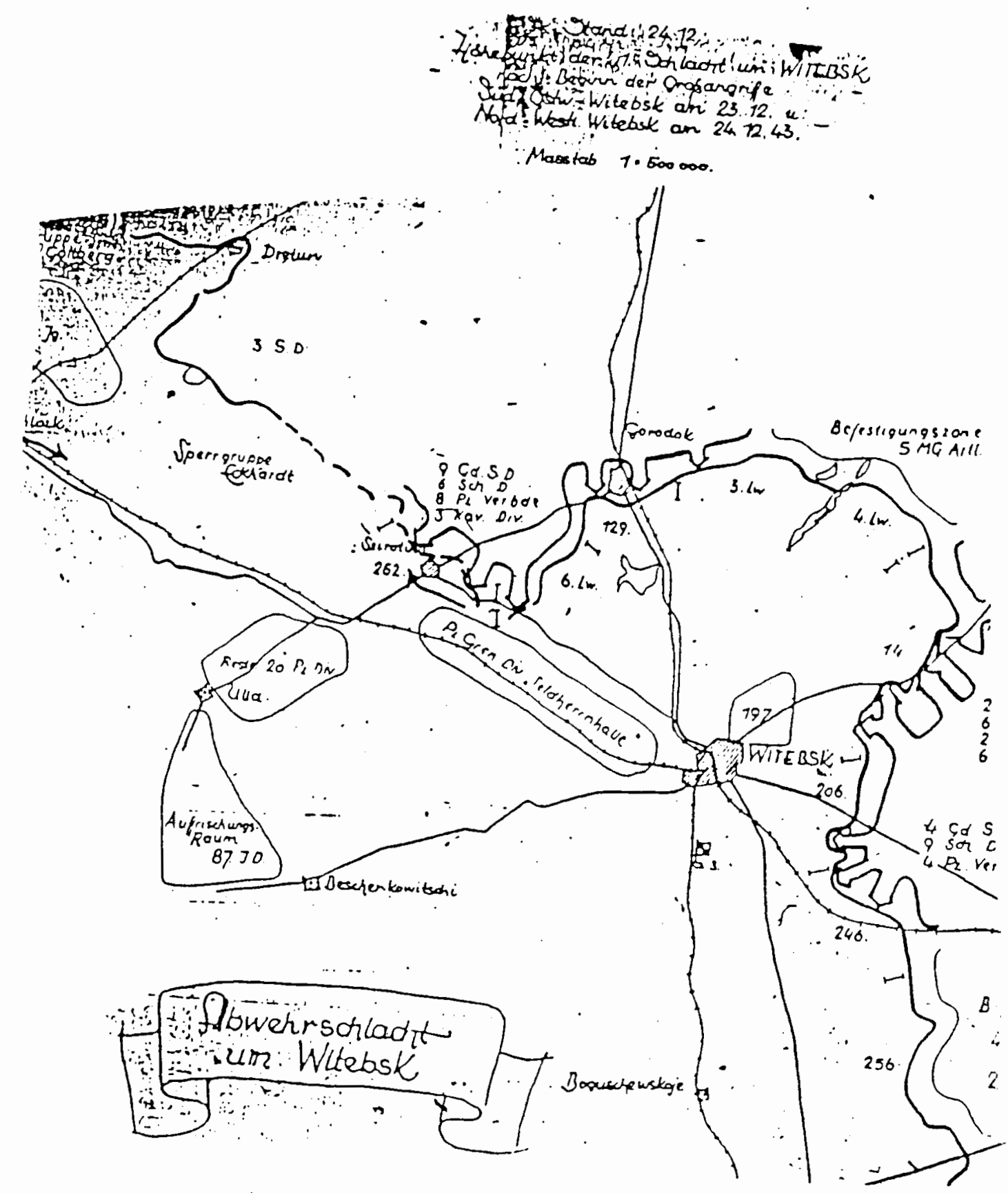

Figure 42. Battle of Vitebsk, December 23-24, 1943. Source: Pz.A.O.K. 3, Die Abwehrschlachten um Witebsk vom 13.12.43 bis 17.2.44. National Archives Microfilm Publication T-313 Roll 291. 


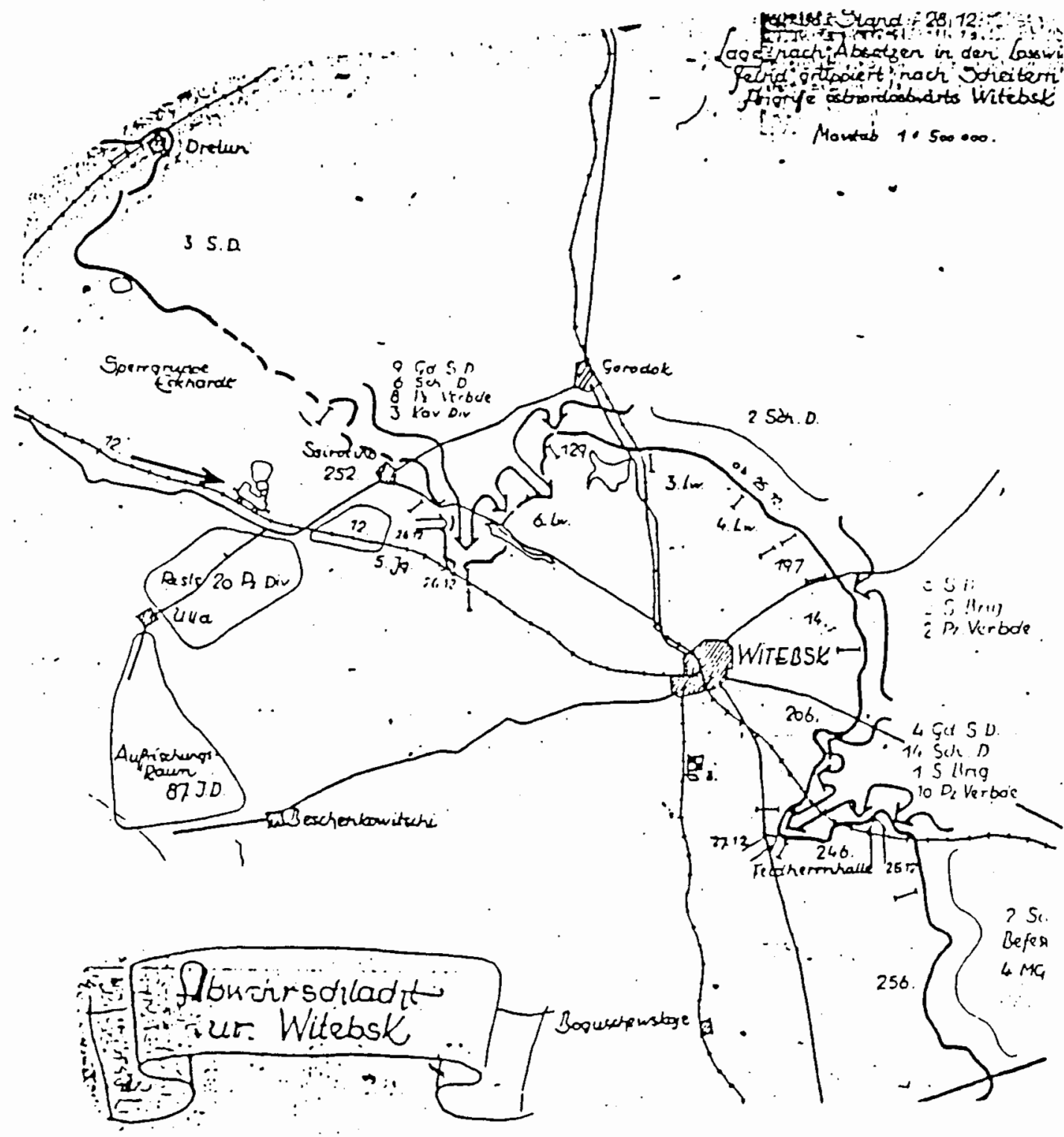

Figure 43. Battle of Vitebsk, December 28, 1943.

Source: Pz.A.O.K. 3, Die Abwehrschlachten um Witebsk vom 13.12.43 bis 17.2.44. National Archives Microfilm Publication T-313 Roll 291. 


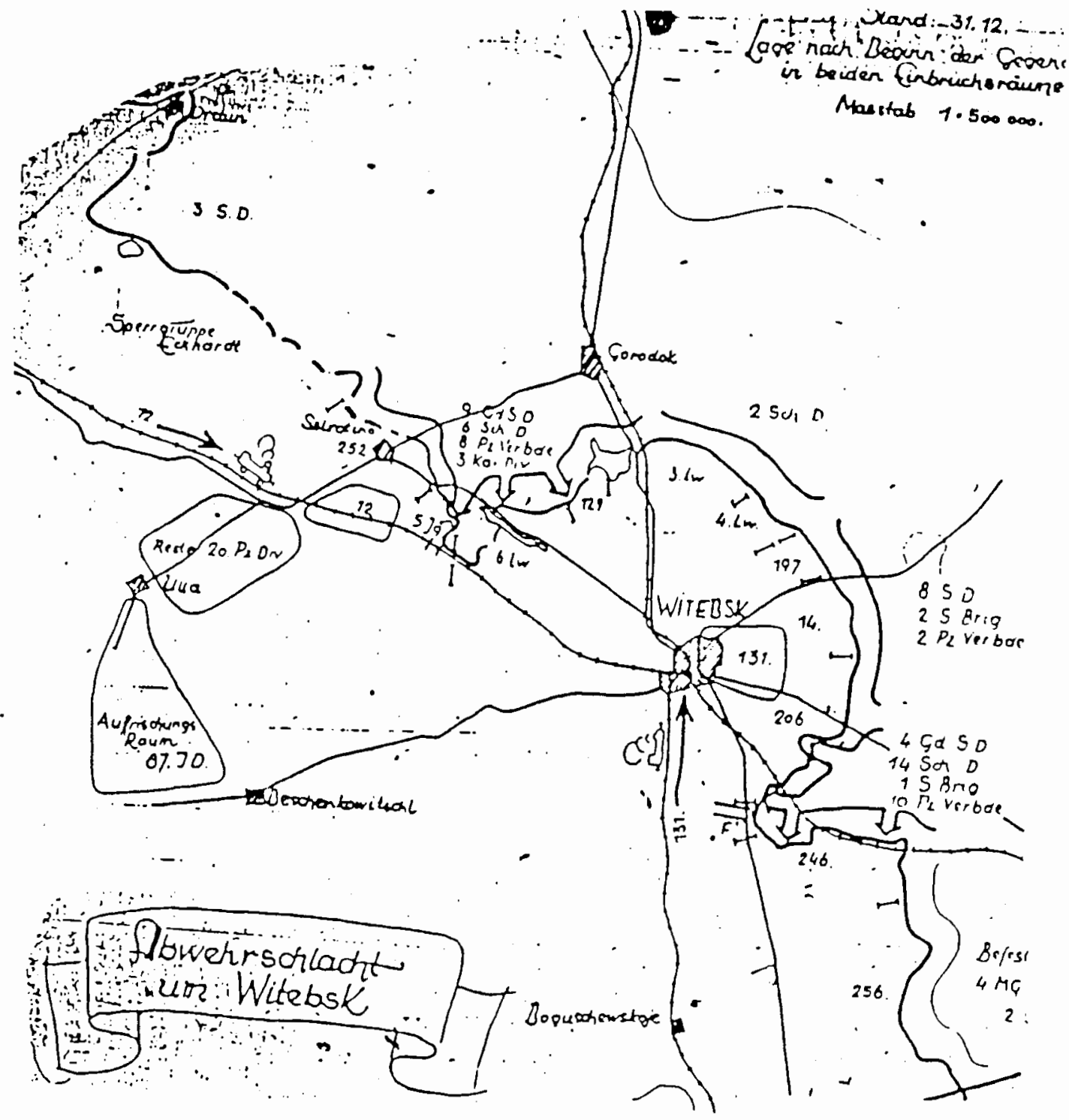

Figure 44. Battle of Vitebsk, December 31, 1943. Source: Pz.A.O.K. 3, Die Abwehrschlachten um Witebsk vom 13.12.43 bis 17.2.44. National Archives Microfilm Publication T-313 Roll 291. 


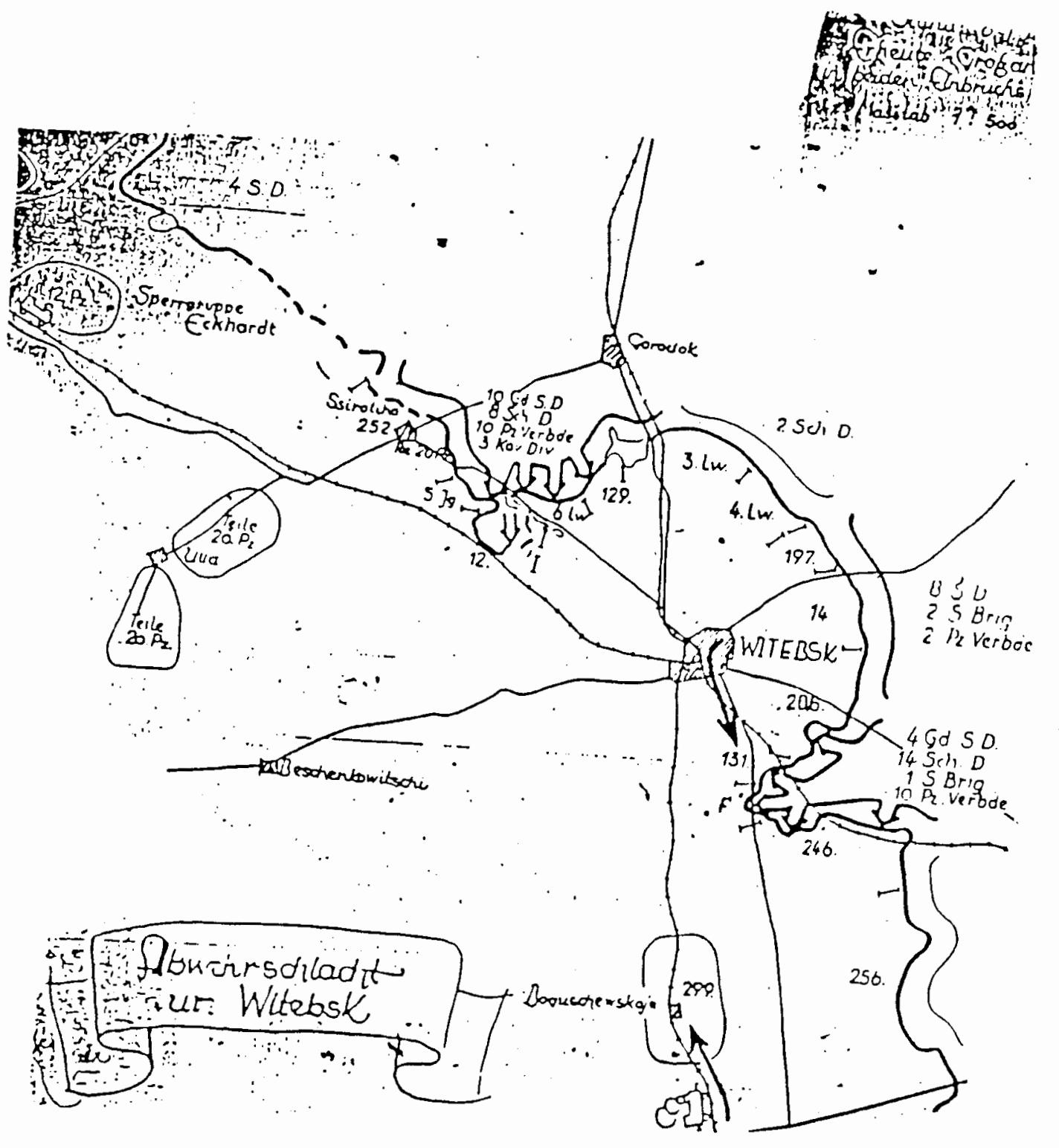

Figure 45. Battle of Vitebsk, January 6, 1944. Source:

Pz.A.O.K. 3, Die Abwehrschlachten um Witebsk vom

13.12.43 bis 17.2.44. National Archives Microfilm Publication T-313 Roll 291. 


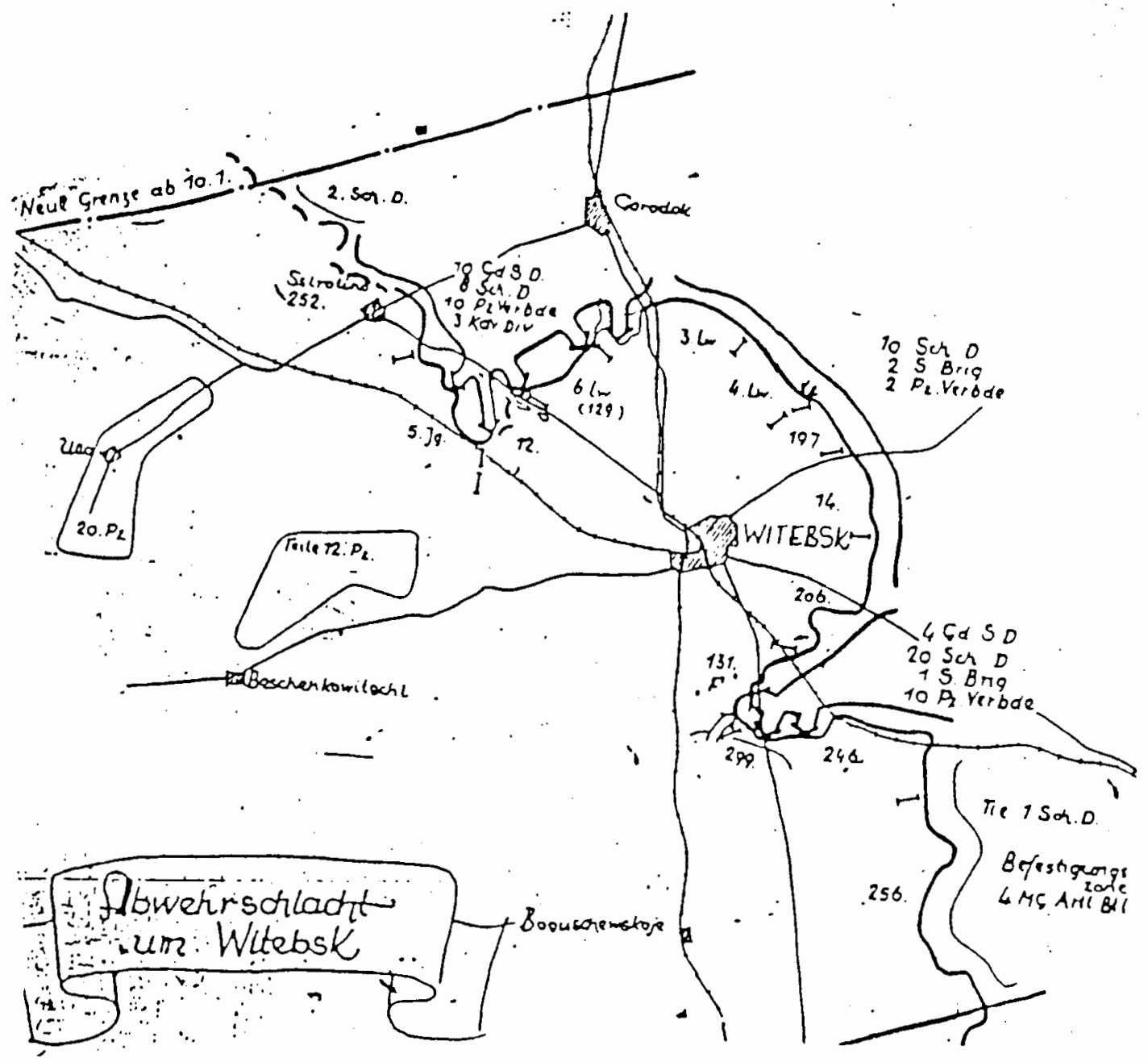

Fiqure 46. Battle of Vitebsk, January 11, 1944. Source: Pz.A.O.K. 3, Die Abwehrschlachten um Witebsk vom 13.12.43 bis 17.2.44. National Archives Microfilm Publication T-313 Roll 291. 


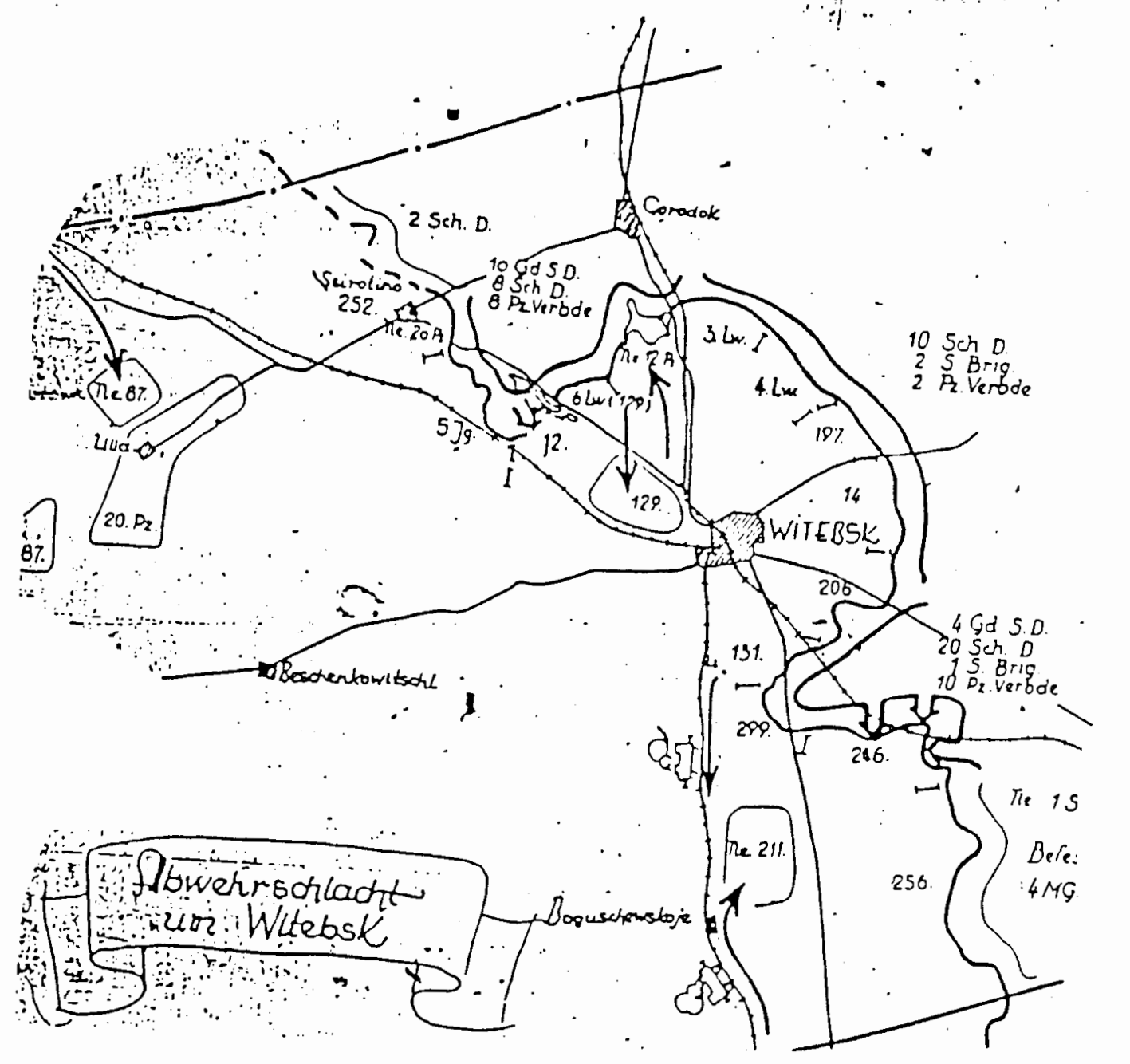

Figure 47. Battle of Vitebsk, January 17, 1944. Source: Pz.A.O.K. 3, Die Abwehrschlachten um Witebsk vom 13.12.43 bis 17.2.44. National Archives Microfilm Publication T-313 Roll 291. 


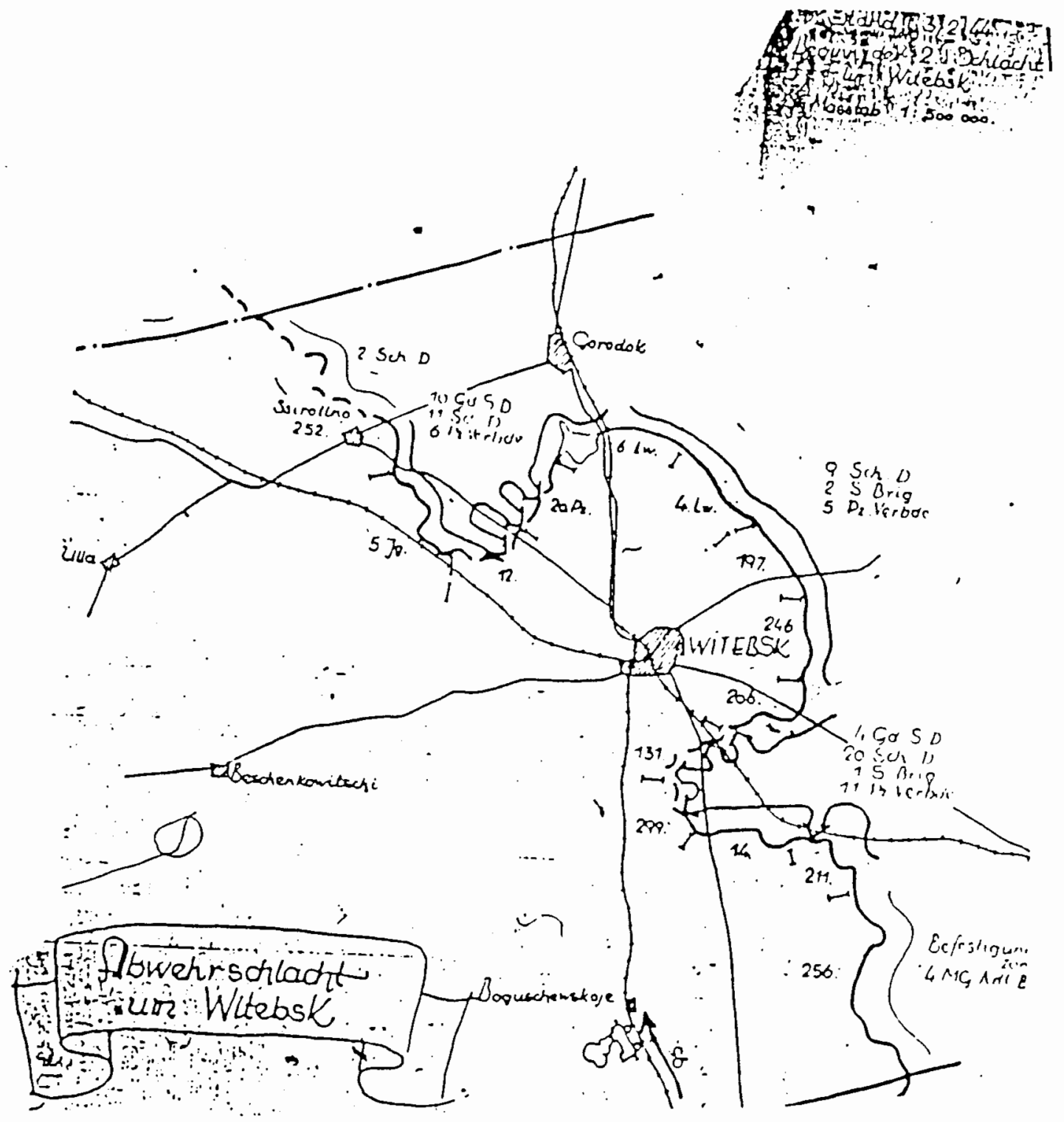

Figure 48. Battle of Vitebsk, February 3, 1944. Source: Pz.A.O.K. 3, Die Abwehrschlachten um Witebsk vom 13.12.43 bis 17.2.44. National Archives Microfilm Publication T-313 Roll 291. 


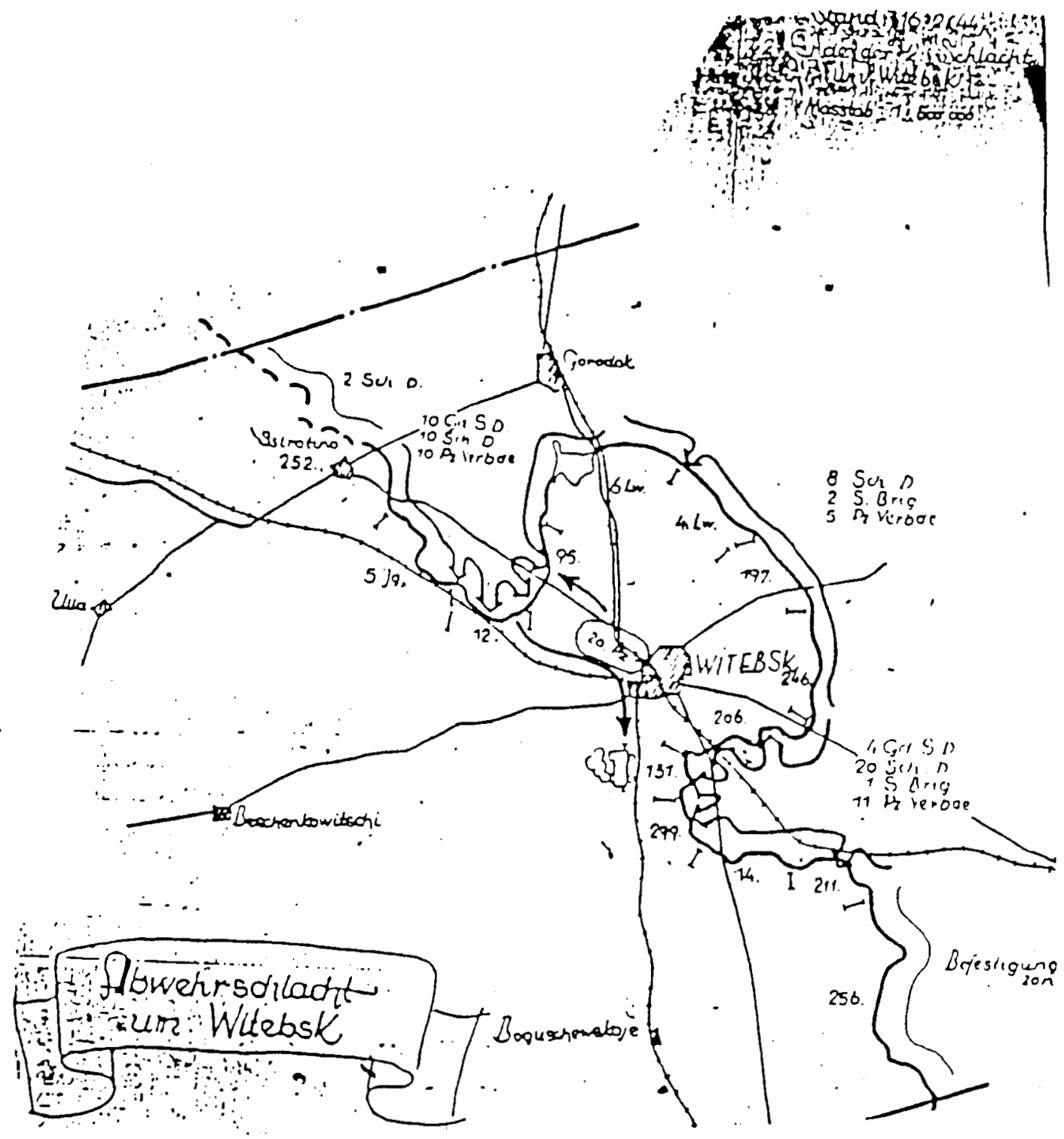

Figure 49. Battle of Vitebsk, February 16, 1944. Source: Pz.A.O.K. 3, Die Abwehrschlachten um Witebsk vom 13.12.43 bis 17.2.44. National Archives Microfilm Publication T-313 Roll 291. 


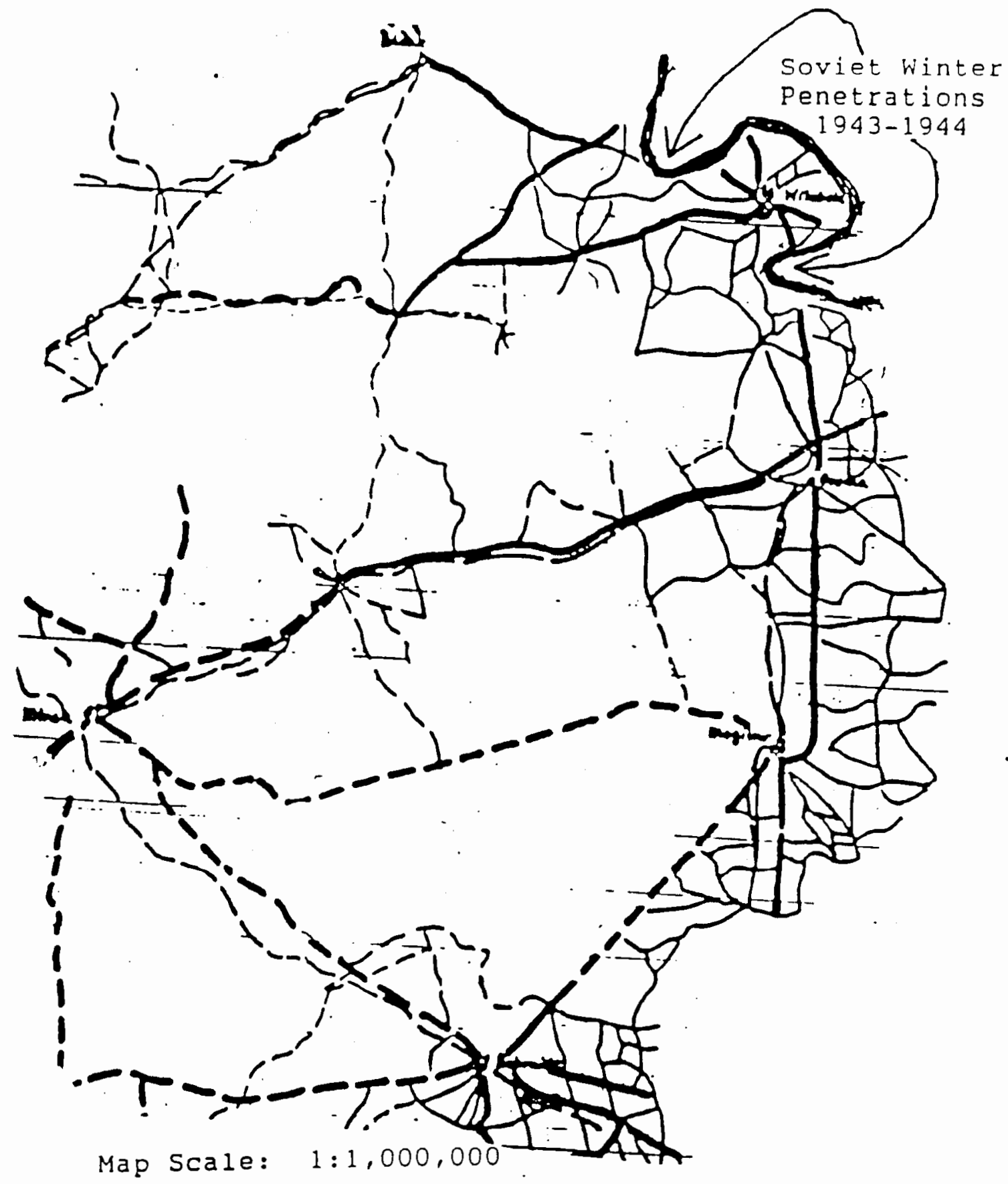

Figure 50. Soviet Winter Penetrations Around Vitebsk, 1943-1944. Source: Verkehrslage-Std.: 22.5.44., National Archives Microfilm Publication T-311 Roll 219. 


\section{NOTES TO CHAPTER VII}

'Kurt Mehner, Die Geheimen Tagesberichte Der Deutschen Wehrmachtfuehrung Im Zweiten Weltkrieg 1939-1945 Vol. 8 (Osnabrueck: Biblio Verlag, 1988), p. 343.

2ibid.

3lbid., p. 400.

4 Ibid.

5Ibid., p. 406 .

6lbid.

7lbid., p. 412.

8lbid., pp. 406 \& 412.

9 lbid., p. 417.

10 lbid.

11 lbid.

12 ibid.

13 lbid., p. 423.

14 /bid., p. 428.

15/bid., p. 437.

16 Ibid., p. 470

17 Ibid., p. 485.

18 /bid.

${ }^{19}$ Kurt Mehner, Die Geheimen Tagesberichte Der Deutschen

Wehrmachtfuehrung Im Zweiten Weltkrieg 1939-1945 Vol. 9 (Osnabrueck: Biblio Verlag, 1987), p. 4.

20Ibid., p. 10.

21 lbid. 
22!bid.

23/bid., p. 15.

24Ibid., p. 21.

25Ibid.

${ }^{26} \mathrm{bid}$.

27P.N. Posepelov et al, History Of The Great Patriotic War of The Soviet Union 1941-1945 Vol. 4 trans. Foreign Technology Division: Air Force Systems Command, (Moscow: Publishing House "Voyennoye," 1962), p. 187.

28 Mehner, Vol. 9, p. 59.

29 lbid., p. 65.

30ibid., p. 69.

31 lbid.

32 Ibid.

33lbid.

34 Ibid., p. 74.

35 Ibid., p. 79.

36 bid.

37/bid., p. 85 .

38 Ibid.

39 ibid.

40/bid., p. 90.

41 Ibid.

${ }^{42}$ lbid.

43lbid. 
44Ibid., p. 100.

45lbid., p. 105.

46|bid., p. 111.

47 lbid.

${ }^{48}$ Ibid.

49 lbid.

50/bid., p. 117.

51 Ibid., p. 122

52/bid., p. 126.

53lbid., pp. 125-126.

54/bid., p. 130.

55 lbid.

56!bid., p. 133.

57/bid., p. 134.

58 Ibid.

59/bid., p. 138.

60lbid., pp. 142-143.

61 bid., p. 147.

62 ibid., p. 151.

63Ibid., p. 156.

64lbid., pp. 161-164.

65 Ibid., p.174.

66 lbid., p. 182. 
67ibid., p. 190.

68/bid., p. 196.

69 lbid.

70lbid., p. 200.

${ }^{71}$ lbid.

72/bid., p. 102

73/bid., p. 207.

74 lbid.

75/bid., p. 215.

76/bid., p. 219.

77 lbid.

78/bid., pp. 222-223.

79/bid., pp. 288-289.

80 lbid., p. 292.

81 lbid.

82 lbid.

83/bid., p. 343.

${ }^{84}$ Ibid.

85 jbid.

86P.N. Pospelov et al, p. 186

87lbid., p. 187.

88 lbid.

89 Ibid. 
90lbid., p. 188

91 Ibid.

92Department Of The Army, German Defense Tactics Against Russian BreakThroughs (Washington, D.C.: Department Of The Army, October 1951), p. 30.

93 bid.

94 Ibid.

95 Ibid.

96 B.H. Liddell Hart, The German Generals Talk (New York: William Morrow \& Co., 1948), pp. 214-215.

97Department Of The Army, German Defense Tactics Against Russian Breakthroughs, p. 30 .

98 Hart, The German Generals Talk, pp. 214-215.

${ }^{99}$ Department Of The Army, German Defense Tactics Against Russian BreakThroughs, p. 31.

100 Ibid., pp. 31-32 
CHAPTER VIII

SOVIET OPERATIONAL PLANNING, NUMERICAL SUPERIORITY AND THE USE OF MASS IN THE BELORUSSIAN SUMMER OFFENSIVE

\section{SOVIET OPERATIONAL PLANNING}

The Soviet General Staff reviewed the situation on the Central Front facing the 1st Baltic, 3rd Belorussian, 2nd Belorussian and 1st Belorussian Fronts after the failure of the winter offensives of 1943-1944 against Army Group Center. Stavka recognized that a fresh approach was required to break the back of the German defense in Belorussia. The Soviet General Staff recognized the need to coordinate the offensive along all four fronts simultaneously to achieve the maximum results. Airpower and artillery support also had to be coordinated to obtain the most optimal conditions for offensive breakthroughs and subsequent exploitation of breaches in the German defensive line by each of the four fronts. The German line had to be breached in several locations simultaneously to tie down German reserves and prevent the German Command from shifting their battalions to breakthrough sites by extending the frontages held by the remaining divisions not under extreme pressure. If this could be achieved the Soviet 
breakthroughs were certain to be successful and could not be blocked effectively.

On April 17-19, 1944, Stavka issued orders for all the fronts to go over to the defensive except for the 2nd and 3rd Ukrainian Fronts. 1 The order stated: "the transition to the defense is a temporary measure to prepare the troops for the subsequent advance operations. ${ }^{2}$ The input and analysis of Front Commanders was considered in the formation of the plan for the Belorussian Summer offensive.

A preliminary plan was formulated under General A.N. Antonov, Deputy Chief of the General Staff of the Red Army on May 20, 1944.3 The plan was code named "Bagration" after General Peter Bagration, the hero of the Battle of Borodino in 1812.4 This plan consisted of two phases. It advocated three main thrusts on the flanks of Army Group Center to liquidate the German salient in the region of Vitebsk-Orsha-Bobruisk-Minsk. ${ }^{5}$ The 3rd Belorussian Front in the north and 1st Belorussian Front in the south were designated to conduct a major pincer movement to encircle most of Army Group Center east of Minsk (see Figure 51). ${ }^{6}$ The third major Schwerpunkt of the Soviet plan was to be conducted by the 1st Baltic Front with an advance northwest of Vitebsk to take Molodechino (see Figure 51). ${ }^{7}$ Once the destruction of the German forces in the German salient of Vitebsk-Orsha-Bobruisk-Minsk had occurred the Soviet advance was to reach the line of Disna, Molodechno, Stolbsty and Starobin. ${ }^{8}$ 
During the May 22-30, 1944 period the initial "Bagration" plan was modified to reflect the lessons learned from the winter battles of 1943-1944 in Belorussia. Three significant changes were made to the original "Bagration" plan:

1. The 1st Baltic Front instead of advancing to Molodechno was to advance along the Western Dvina river to prevent German Army Group North from reinforcing Army Group Center. This action would help complete the Soviet encirclement of German forces east of Minsk.

2. The depth of the operation was extended further to the west. The phase one objectives to be completed by July 15 th were moved further west to the line Druya-Svencionys-StolbtsyZhitkovichi (see Figure 52). 9 Phase two objectives provided for the left wing of the 1st Belorussian Front to join the offensive and the combined fronts were to reach the line Rezekne-DaugavpilsGrodno-Lublin by August 15, 1944 (see Figure 52). ${ }^{10}$ The total operation was projected for an advance of 550 to 600 kilometers to the west. ${ }^{11}$

3. The number of divisions was increased in the main breakthrough areas from 77 to 97 divisions. ${ }^{12}$ The 1st Baltic, 3rd and 1st Belorussian Fronts were to first surround and destroy the flanks of Army Group Center in the area of Vitebsk and Bobruisk. The 3rd and 2nd Belorussian Fronts were to attack in the center toward Orsha and Mogilev. Once the flanks had been destroyed the three Belorussian Fronts were to converge on Minsk surrounding the German 4th and 9th Armies east of the city. ${ }^{13}$ Finally, Stavka 
decided that six breakthroughs in the German front in widely separated sectors were required. ${ }^{14}$ The six separate breakthroughs were to dismember the German defense; breakup the German forces; and scatter the German reserves so they could not concentrate to repel the Soviet breakthroughs. The four attacking fronts each were assigned a breakthrough area with the 3rd and 1st Belorussian Fronts receiving two assigned breakthrough areas.

\section{First Breakthrough Sector}

The 1st Baltic Front was to breach the German defense line with two armies southwest of Gorodok and take the area of Beshenkovichi. ${ }^{15}$ A portion of this force was to assist the right flank of the 3rd Belorussian Front in seizing Vitebsk. Once this front was secure then the advance on Lepel was to proceed.

\section{Second and Third Breakthrough Sectors}

The 3rd Belorussian Front was assigned two breakthrough points. Two armies were to penetrate from the area west of Liozno to take Senno and then proceed to take Vitebsk in cooperation with the 1st Baltic Front. ${ }^{16}$ The second area was also assigned two armies which were to advance along the Minsk main highway and take Borisov. Once the cities of Senno and Orsha had fallen the Front's mobile forces were to break through to the western bank of the Berezina river in the area of Borisov. 


\section{Fourth Breakthrough Sector}

The 2nd Belorussian Front was assigned the task of taking Mogilev and breaking through to the Berezina river in cooperation with the 3rd and 1st Belorussian Fronts. ${ }^{17}$ This front was to employ one reinforced army to take Mogilev and then advance along the Mogilev-Minsk highway to the Berezina. ${ }^{18}$

\section{Fifth and Sixth Breakthrough Sectors}

The 1st Belorussian Front was assigned two breakthrough areas. The fifth breakthrough was to be made by two armies from the area of Rogachev to Bobruisk-Osipovichi. ${ }^{19}$ The sixth breakthrough was to employ two armies from the area of Ozarichi in an advance toward Slutsk.20 The Front was to surround and destroy the Germans in Bobruisk and seize the region of BobruiskGlusha-Glusk. ${ }^{21}$ The advance was then to proceed to OsipovichiPukhovichi and on to Slutsk.

The Soviet plan utilized two combined armies to make each penetration except for the penetration on the 2nd Belorussian Front. Therefore, a total of 11 armies were to make the initial penetrations against Army Group Center (see Figure 53). The combined effect of this offensive by 11 armies with mechanized and tank forces in reserve to exploit the initial breakthroughs was certain to shatter the German main defense line. 
Soviet Reinforcements

The Soviet General Staff made the decision to reinforce the four fronts for the Summer Belorussian Offensive. During a twomonth period the Soviets redeployed three combined armies and one rifle corps (totaling 28 to 30 divisions), two tank armies, three tank corps, one mechanized corps and two cavalry corps to the four fronts assigned to Operation "Bagration."22 The 1st Tank Corps was transfered to the 1st Baltic Front. The 11th Guards Army and the 2nd Guards Tank Corps were added to the 3rd Belorussian Front. The 2nd Belorussian Front was reinforced with the 81st Rifle Corps. The right wing of the 1 st Belorussian Front received the 28th Army, the 9th and 1st Guard Tank Corps, the 1st Mechanized and the 4th Guards Cavalry Corps. The left wing of the 1st Belorussian Front received the 8th Guards, 2nd Tank Army and the 2nd Guards Cavalry Corps. The 3rd Belorussian Front received the 5th Guards Tank Army. ${ }^{23}$ Stavka reserves from the Crimea consisting of the 2nd Guards and 51st Armies were moved to the Smolensk area.24 The airpower in the 4 air armies supporting the four fronts were increased. Eleven air force corps and five air force divisions were added to the four air armies.

The four Soviet fronts had a total of 166 divisions, 9 rifle brigades and fortified regions, 31,000 artillery guns and mortars (76-millimeter and above), 5,200 tanks and self-propelled guns, 6000 frontal aircraft, and approximately 1000 aircraft from the Long Range Air Force.25 If the southern wing of the 1st Belorussian Front is not counted because it would not participate in the first 
phase of "Bagration" then the actual number of Soviet divisions participating in the start of the offensive drops to 124 divisions, 9 rifle brigades and fortified regions, 24,400 artillery weapons and mortars (76-millimeter and above), 4,000 tanks and self-propelled guns, and 5,300 frontal aircraft (excluding the aircraft of the Long Range Air force). 26 According to Soviet sources the Soviet High Command had concentrated $38 \%$ of its rifle and $40 \%$ of its tank and mechanized formations, and $47 \%$ of all frontal aircraft in the four Soviet fronts which were to launch Operation "Bagration."27 This commitment of resources would permit the Soviet fronts to achieve the success that they had failed to achieve in the winter of 1943-1944 in Belorussia.

\section{FINAL STAVKA PLAN}

The Stavka plan emerged as summarized in Figure 54. Stavka issued formal directives to the four attacking front commanders and they made the decisions on how to execute the directives in operations on their respective fronts. ${ }^{28}$

\section{1st Baltic Front}

General Bagramyan, Commander of the 1st Baltic Front assigned the 6th Guards Army under General Chistyakov and the 43rd Army under General Beloborodov to breach the German defense line southwest of Gorodok along a 25 kilometer sector. The armies were to occupy Beshenkovichi and cross the Western Dvina. A 
portion of the 43rd Army would participate with the 39th Army of the 3rd Belorussian Front in surrounding and capturing Vitebsk. ${ }^{29}$ Once the Polotsk-Vitebsk railroad had been seized the 1st Tank Corps was to exploit the breach and cross the Western Dvina and attack Beshenkovichi along with the advancing armies. ${ }^{30}$ Lepel was also assigned to be captured.

\section{3rd Belorussian Front}

General Chernyakhovskiy, Commander of the 3rd Belorussian Front formed two strike groups within the front. The northern group consisted of the 39th, 5th Armies, and a mounted mechanized group which contained the 3rd Cavalry and 3rd Mechanized Guard Corps. ${ }^{31}$ The southern group consisted of the 11th Guards and 31st Armies (see Figure 55). ${ }^{32}$

The northern strike group was assigned to breach an 18 kilometer sector southeast of Vitebsk. The 39th Army under General Lyudnikov on the right flank was to take Gnezdilovichi and in cooperation with the 43rd Army of the 1st Baltic Front surround and seize Vitebsk.33 The 5th Army under General Krylov was to advance along the Bogushevsk-Senno axis and in cooperation with the Ilth Guards Army destroy the German 4th Army at Orsha. ${ }^{34}$ Once this objective was achieved the 5th Army was to emerge at the Berezina river. When the 5th Army had secured the Luchesa river the Mounted Mechanized group under General Oslikovskiy was to exploit the breakthrough and secure crossings on the Berezina river northwest of Borisov. ${ }^{35}$ 
The southern strike group was ordered to break a 15 kilometer sector of the German front before Orsha with the IIth Guards Army under General Galitskiy and the 31st Army under General Glagolev.36 Both armies were assigned to seize Orsha and advance along the Minsk highway to Borisov. The mobile group of the 11th Guards Army and the 2nd Guards Tank Corps were to exploit the breakthrough and advance to the Berezina near Chernyavka.

The 5th Guards Tank Army commanded by Marshal Rotmistrov was to exploit the advance of the Ilth Guards Army and advance along the Minsk main highway to Borisov or advance through the breach created by the 5th Army toward Bogushevsk-TolochinBorisov. Rotmistov's 5th Guards Tank Army would be employed along either axis depending on which route offered the most opportunity for advancing.

\section{2nd Belorussian Front}

General Zakharov, Commander of the 2nd Belorussian Front assigned the 49th Army under General Grishin to liberate Mogilev and then advance to the Berezina river. ${ }^{37}$ The 50th Army under General Boldin and 33rd Army under General Kryuchenkina were ordered to hold their present lines. However, the 50th Army was to have one rifle corps in reserve to exploit any breakthrough by the 49th Army toward Chausy or Blagovichi. 


\section{1st Belorussian Front}

General Rokossovskiy, Commander of the 1st Belorussian Front divided his armies into northern and southern strike groups. The northern group was assigned to penetrate a 17 kilometer sector north of Rogachev. ${ }^{38}$ The southern group was ordered to breakthrough on a 15 kilometer front to the south of Parichi. ${ }^{39}$ The coordinated attacks by these two groups were to achieve the encirclement and destruction of the German 9th Army at Bobruisk with a subsequent advance toward Pukhovichi and Slutsk.

The northern group assigned to attack north of Rogachev consisted of the 3rd Army under General Gorbatov and the 48th Army under General Romanenko. ${ }^{40}$ The 9th Tank Corps under General Bakharov constituted the Mobile Group of the 3rd Army. It was assigned to move into the Bobruisk area and cut off the German lines of communication after a breakthrough in the main German defensive line had been achieved.

The southern strike group contained the 65th Army under General Batov, the 28th Army under General Luchinskiy and the Mounted Mechanized group which included the 4th Guards Cavalry and the 1st Mechanized Corps under the command of General Pliyev. ${ }^{41}$ The Mounted Mechanized group was assigned to enter the breach achieved at the boundary of the 65th and 28th Armies. It was to advance on Slutsk, Osipovichi or Bobruisk depending on circumstances.

Meanwhile, the forces on the left flank of the 1st Belorussian Front were to conduct active operations to prevent German units 
from being transferred to the Minsk sector as reinforcements. This group of forces was to be held in reserve for the subsequent advance toward the Kovel-lyublin direction.

\section{Dnieper Military Flotilla}

The Dnieper Military flotilla was assigned the task of assisting the southern strike group of the 1st Belorussian Front. It was to serve as floating artillery and as transport for the 48th Army in crossing over to the west bank of the Berezina.42 It was also assigned to block the Germans from retreating behind the Berezina at river crossings.

\section{Soviet Airpower}

The four fronts undertaking the summer offensive in Belorussia were supported by air armies assigned specifically to each front and by Long Range Aircraft.

3rd Air Army. The 1st Baltic Front was supported by the 3rd Air Army. ${ }^{43}$ The 3rd Air Army's air assault division was assigned to neutralize the German artillery and mortar positions. The fighter aircraft were to provide air cover for the advancing ground forces.

1st Air Army. The 3rd Belorussian Front was supported by the 1st Air Army. ${ }^{44}$ The 1st Air Army was divided into two air force groups: one air force group supported the northern strike group and the southern strike group was supported by the larger air force group which was to assist the troops advancing toward Orsha. 
The 1st Air Army was also tasked to help breach German lines; destroy the German forces surrounded at Vitebsk; and support the Mobile Group operating in depth in the German rear. ${ }^{45}$

\section{4th Air Army. The 4th Air Army supported the 2nd}

Belorussian Front.46 The 4th Air Army operations were planned for ohly the first day of the offensive. One night bomber division and two bomber corps of long distance aircraft were to bomb the forward edge of the German defense line the night preceding the offensive. The advancing strike group on the ground was to receive support from one fighter and two assault air divisions.

16th and 6th Air Armies. The 16th Air Army assigned to support the 1st Belorussian Front was divided into two air force groups: one northern group which was to be the strongest group and the southern group. 47 This division of airpower reflected the division of ground forces into their two respective groups. In addition the 6th Air Army was transferred from the general reserve to the 1st Belorussian Front.48 Two night bomber divisions and long distance aircraft were to bomb the main centers of German defense on the night preceding the offensive.

Long Range Aviation. The long range aircraft held in the general Soviet reserve were also employed in the Belorussian offensive. 1000 aircraft were committed to the task of neutralizing the German Luftflotte 6 at the following airfields: Belostock, Brest, Luninets, Baranovichi, Bobruisk, Minsk, and Orsha which comprised 60 per cent of the 6th Air Fleets aircraft. ${ }^{49}$ Ten days before the start of the Belorussian Operation long range 
aviation conducted a night air operation lasting four nights between June 13-18, 1944 where heavy bombers flew 1,472 sorties to neutralize the German 6th Air Fleet.50 The German rail lines were also targeted for bombing. The long range aircraft were assigned to bomb the German defenses in the six breakthrough sectors on the night preceding the Soviet main offensive. ${ }^{51}$

The total Soviet aircraft deployed in the five Soviet air armies amounted to 6,000 planes including more than 1,100 day and night bombers and 2,000 ground attack aircraft.52 In addition, 1,000 bombers from Long Range Aviation were included in the Soviet offensive operations. Ten air corps and eight air divisions were dispatched to reinforce the five Soviet air armies during the first half of June 1944 which required the additional construction of 70 airfields. 53

The 1st Air Army in the 3rd Belorussian Front and the and the 16th Air Army in the 1st Belorussian Front received 70 per cent of all planes and all day bombers. ${ }^{54}$ Three air corps and two independent air divisions were massed in the 1st and 16th Air Armies. The 16th Air Army was divided into two groups: 13 air divisions in the northern group and 7 air divisions in the southern group.55 The 1st Air Army was also divided into two groups: 6 air divisions were to operate in the Bogushevsk sector and 11 air divisions in the Orsha sector.56 The Soviet High Command desired to maximize the effect of their air power resources by postponing the offensive of the 1st Belorussian Front by one day so that aircraft of the Long Range Aviation could be concentrated totally in 
support of the 1st Baltic, 3rd Belorussian, and 2nd Belorussian Fronts on the first day of offensive operations. 57 On the second day of the offensive the long range aircraft were transferred to support the 1st Belorussian Front which commenced its offensive. ${ }^{58}$

\section{Soviet Partisans}

The partisans were assigned several tasks in the German rear areas. The main tasks were to attack the German lines of communication, cut and hold certain roads and railroad junctions, capture bridges, seize river crossings and hold them till units of the Red Army arrived. Specifically, the partisan units behind the German lines opposing each of the four fronts: 1st Baltic, 3rd Belorussian, 2nd Belorussian, and 1st Belorussian were to attack German lines of communication. Railroads were the chief means of moving supplies throughout the Russian campaign for both the Germans and the Soviets. ${ }^{59}$ Therefore, an attack on the railroads constituted a significant threat to German defensive and offensive operations (see Figure 56).

Partisan units with approximately 71,000 members located directly in the rear area of Army Group Center in June 1944 (see Figure 57) constituted a serious threat. There were approximately 143,000 Belorussian partisans organized into 150 brigades and 49 separate detachments throughout Belorussia.60 Figure 58 delineates the partisan strength in Belorussia as of March 1944. However, the partisan strength was reduced by German antipartisan operations between April and June 1944. Operations Regenschauer, 
Fruehlingsfest, and Kormoron (see Figure 59) eliminated approximately 27,000 partisans with several thousand escaping the areas of German antipartisan operations.61 This weakened the partisans prior to the start of the Belorussian Offensive. The partisan bands generally were organized into groups of 3000 to 5000 men each.62 Partisan operations were almost always conducted at night. Such operations included: (1) mining main highways; (2) demolition of railroad tracks; (3) mining railroad beds; and (4) surprise attacks on trains and truck convoys. ${ }^{63}$ The partisan units were ordered to attack and completely paralyze German rail activity beginning on June 20, 1944 with massive demolition of the main rail lines.64 The main railroad targets were the Polotsk-Molodechno, Glubokoye-Vilnius, Minsk-Orsha, MinskBrest and Pinsk-Brest rail lines. 65

The partisan attack on the night of June 19-20, 1944 constituted the largest attack of the war by partisans against the German lines of communication. 66 The partisans attempted 15,000 demolitions on the railroad lines behind Army Group Center (see Figure 60 ) on the night of June 19-20, 1944.67 10,500 demolitions were successful in the course of one night.68 This number of demolitions on one night amounted to $2 / 3$ of the total demolitions for the month of May 1944.69 The double-tracked rail lines were blocked for 24 hours and single-tracked rail lines were interrupted for over 48 hours. ${ }^{70}$ The Commander of the Railroad Engineer Brigade \#2 in Army Group Center on June 20, 1944 reported 600 demolitions on the Orsha-Mogilev rail line and 580 demolitions on 
the Minsk-Orsha rail line. ${ }^{71}$ Reconstruction was undertaken immediately. On June 21,1944 at 1300 the railroad engineers had restored the eastward railroad line between Orsha and Mogilev. ${ }^{72}$ The Minsk-Orsha rail line had one rail line open as of 2030 on June 20, $1944 .{ }^{73}$ Both eastern and western rail lines between Minsk and Orsha were operational by 1800 on June 22, $1944 .{ }^{74}$

The partisans struck again on the night of June 20-21, 1944. However, there were 90 per cent fewer rail line demolitions. ${ }^{75}$ There were no demolitions on the night of June 22-23, 1944.76 Apparently, the partisans ran out of explosives thereby allowing the Germans a 48 hour period to restore their rail lines prior to the start of the Soviet offensive in Belorussia. 77 The German rail lines Dvinsk-Molodechno, Minsk-Orsha and Minsk-Bobruisk were all open as of June $27,1944 .{ }^{78}$ Reinforcements and supplies were moving from one sector to the next sector. Thus, Soviet planning of partisan action against German lines of communication was poor. Soviet directives should have targeted the rail lines simultaneously with the general offensive to achieve the maximum effect.

\section{NUMERICAL SUPERIORITY}

The Soviets had achieved numerical superiority on the Belorussian Front. The Soviets had massed 14 combined arms armies, 1 tank army, 8 tank and mechanized Corps, 2 cavalry corps 
and 4 air armies (see Table XXVIII). ${ }^{79}$ Soviet equipment amounted to 30,916 artillery guns, multiple rocket launchers, anti-aircraft guns and mortars, 4,070 tanks and self propelled guns (see Table $X X(X)$, and 5,327 aircraft in addition to over 1000 long range aircraft (see Table XXX). ${ }^{80}$ Between January 1, 1944 and June 1, 1944 the number of German troops opposing the Soviets declined by $900,000.81$ Soviet sources put their overall superiority at 1.7:1 in troops; $1.8: 1$ in Guns and Mortars (antiaircraft artillery excluded); 1.6:1 in tanks and assault guns and 4.9:1 in operational aircraft. ${ }^{82}$ However, on the Belorussian Front Soviet superiority reached levels that exceeded 2:1 in all categories of military manpower and equipment. (see Figure 61) This level of numerical superiority does not reflect the actual situation on the respective Soviet Fronts facing German Army Group Center. On the 1st Baltic and 1st Belorussian Front troop strengths reached 3:1 and on all fronts tank strength exceeded 3:1 (see Figure 61).

The order of battle of German forces as of June 22, 1944 showed the Soviets being opposed by only 39 infantry divisions, 3 Panzer Grenadier divisions, 1 Panzer division, and 6 security divisions. ${ }^{83}$ This German strength contrasted with the Soviet strength in Table XXVIII delineates a substantial Soviet numerical superiority in Soviet formations. The actual numerical strength of the Soviet Fronts is enumerated in Table XXIX. Soviet numerical superiority was clearly established by numbers, but it was the concentration of this Soviet mass that was to produce such spectacular success in the Belorussian Operation. 
CONCENTRATION AND MASS IN THE SOVIET OFFENSIVE IN BELORUSSIA

\section{German Defensive Concentration}

The German formations in Army Group Center were forced to hold sectors of the front line which were too wide to be effectively defended. The 29 divisions in the front line each had to hold a frontage of between 24 and 32 kilometers. ${ }^{84}$ There were few divisions which had a smaller sector to hold. The 25th Panzer Grenadier Division had the smallest sector to hold which was 17 kilometers. ${ }^{85}$ According to German sources there was an average density of 80 men per kilometer. ${ }^{86}$ German divisional artillery had ranges of $12.3 \mathrm{~km}$ and $13.3 \mathrm{~km}$ for their light and heavy guns. Therefore, German divisional artiliery was not able to mass their fire on every sector of the divisional front line. In addition, there was a shortage of artillery ammunition which prevented really effective artillery bombardments. ${ }^{87}$ German infantry was supported on an average by two to three artillery tubes and one or two assault guns or tanks per kilometer of front. 88

\section{Soviet Concentration of Mass in the Offensive}

The Soviets achieved an overwhelming superiority in the breakthrough sectors despite an overall 3:1 superiority of forces along the front. It was the bold concentration of forces that permitted the Soviets to shatter even the most formidable German defenses (see Figure 62 for an example of German defenses that could be found on the Belorussian Front). ${ }^{89}$ The four Soviet 
attacking fronts had an average total divisional frontage of 5.8 kilometers per division (see Table $X X X 1$ ) compared to 24 to 32 kilometers for the German divisions.90 The concentration of Soviet forces was compressed further in the breakthrough sectors. The average divisional frontage of 5.8 kilometers was compressed to $1.5 \mathrm{~km}$ per division in the breakthrough sectors (see Table $X X X \mathrm{X}$ ). Soviet divisions were organized into two echelons (see Table XXXII) in order to use mass in the breakthrough sectors. The use of more than one echelon was a main factor in determining the success of the breakthrough operation and in maintaining the rapidity of the tempo in the attack. The second and succeeding echelons were committed once the fighting in the first defensive positions had been completely liquidated.91 The second echelon would then be committed to battle which facilitated the forward movement of the breakthrough. This allowed the Soviets to follow up the initial attacks of the first echelon with fresh follow on attacks from the second echelon. The overwhelming superiority achieved by the Soviets can be best described in terms of an attacking rifle division. A leading rifle division in the breakthrough sector with nine rifle battalions of 380 men each each attacking on a frontage of 2.5 to 3 kilometers would achieve a superiority of 10:1.92 The first wave of infantry would put 750 Soviet infantrymen in battle with 80 German soldiers. ${ }^{93}$

The Germans in the past had been able to withstand such pressure and defeat the Soviets. However, the concentration of artillery, armor, airpower, and coordinated flank attacks would 
prove too much for the tenacious German defenders. In many cases, the Soviet attacking frontage was actually 1.5 kilometers, and Soviet troop superiority reached $15: 1$ in the breakthrough sectors. ${ }^{94}$

\section{Soviet Armor}

The Soviet superiority in armor in the breakthrough sectors amounted to $20: 1.95$ The Soviets had allocated $38 \%$ of the available armored vehicles for close support of the infantry in the breakthrough sector. 96 The remaining $62 \%$ of the armored forces were located in the four tank corps, two cavalry/mechanized groups, and the 5th Guards Tank Army. ${ }^{97}$ These formations were formed into mobile groups which were held in reserve until a breakthrough had been achieved. These mobile groups would then exploit breakthroughs to penetrate the front in depth to encircle German forces and reach deep objectives in the German rear area. Soviet armor concentrations in the breakthrough area were massive. The number of tanks in the breakthrough area averaged 35.6 tanks per kilometer (see Table XXXIII). However, the range of Soviet armor concentration varied from 22 per kilometer in the 1st Baltic Front to 45 tanks per kilometer in the 1st Belorussian.98

\section{Soviet Artillery}

The majority of the Soviet Artillery was concentrated on the breakthrough sectors. In fact, $71 \%$ to $80 \%$ of all artillery in the 1 st Baltic, 3rd Belorussian, and 1st Belorussian Fronts targeted the breakthrough sectors which covered only $11-20 \%$ of the general 
offensive area.99 In the 2nd Belorussian Front's attack sector only $50 \%$ of the artillery was concentrated in the attack sector. 100 The Soviets developed an artillery superiority of $35: 1.101$ On the average 5 German guns and rocket launchers opposed 178 Soviet artillery guns or rocket launchers. ${ }^{102}$ The Soviet artillery density per kilometer ranged from 151 to 204 tubes per kilometer depending on the attacking front (see Table XXXIV). ${ }^{103}$ Thus, Soviet artillery was used on a massive scale compared to German artillery.

\section{Soviet Artillery Preparation}

The artillery preparation was of a weight and intensity not previously experienced in this war. ${ }^{104}$ Artillery and mortar preparation lasted from 120 to 140 minutes. ${ }^{105}$ The northern fronts commenced firing between 0600 to 0700 and the 1 st Belorussian Front commenced firing a day later between 0400 and 0500 hours. The fire plan called for three areas of concentration:

(1) 15 minute concentration on defensive positions $3 \mathrm{~km}$ in depth;

(2) 90 minutes of fire on preplanned, observed targets, artillery and heavy weapons positions; (3) 20 minutes of concentration on the main defensive works starting with $25 \%$ of the guns firing with 5 minute incremental increases in intensity till $100 \%$ of the guns were firing intensely. 106 When the troops were to launch an attack they were to be preceded by a rolling barrage reaching out to 2 kilometers. 107 The Soviet advance was closely coordinated with the artillery preparation so that the gap between the artillery 
preparation and the beginning of the infantry assault could be avoided. The intensity of the artillery barrage increased toward the end and when the fire was at its most intense moment the tanks and infantry were already approaching the wall of fire. The tanks maintained a distance of $80-100$ meters from the wall of fire while the infantry maintained a 150 to 200 meter distance. 108

\section{Soviet Use of Mass in the Four Attacking Fronts}

The overall frontage of the four attacking fronts was 690 kilometers, but the six major breakthrough areas only made up 112 $\mathrm{km}$ or $16.3 \%$ of the total front. 109 In this area the Soviets had concentrated $65 \%$ of their rifle divisions, $72.3 \%$ of their guns and mortars, and $86.6 \%$ of their tank and mechanized Brigades. ${ }^{110}$ This permitted an attack with the use of echelons in depth. The 1st Baltic Front was to attack on a 25 kilometer front with 16 divisions, 151 guns and mortars per $\mathrm{km}$, and 22 tanks per km. ${ }^{111}$ The 3rd Belorussian Front was attacking on northern and southern sectors. The northern breakthrough sector was $17.5 \mathrm{~km}$ wide. Ten rifle divisions were assigned to this sector. The southern breakthrough area was $19.5 \mathrm{~km}$ wide with 15 rifle divisions, 175 guns and mortars per km, and 44 tanks per km. ${ }^{112}$ The 2nd Belorussian Front's attack sector was $12 \mathrm{~km}$ with 10 rifle divisions, 181 guns and mortars per $\mathrm{km}$, and 19 tanks and assault guns per km.113 The 1st Belorussian Front's northern group was attacking on a 17 kilometer sector with 13 divisions. The southern group employed 13 divisions on a 21 kilometer sector. Both groups 
had approximately 204 guns and mortars and 45 tanks per kilometer.114 Thus, the Soviets had achieved the mass and concentration of forces in the six breakthrough areas necessary to overcome the German defenses in Belorussia. 
TABLE XXVIII

SOVIET ORDER OF BATTLE, JUNE 1944

SOVIET FRONTS

1st Baltic Front

3rd Belorussian Front

2nd Belorussian Front

1st Belorussian Front (right wing)
SOVIET FORMATIONS

4th Shock Army

6th Guards Army

43rd Army

1st Tank Corps

5th Army

31st Army

39th Army

11th Guards Army

2nd Guards Tank Corps

5th Guards Tank Army

Cavalry/Mechanized Group:

3rd Guards Cavalry Corps

3rd Guards Mechanized Corps

3rd Guards Tank Corps

29th Tank Corps

33rd Army

49th Army

50th Army

Front Mobile Group

3rd Army

28th Army

48th Army

65th Army

9th Tank Corps

Cavalry/Mechanized Group:

1st Guards Tank Corps

4th Guards Cavalry Corps

1st Mechanized Corps

Source: Gerd Niepold, Battle For White Russia: The Destruction of Army Group Centre June 1944 (London: Brassey's Defense Publishers, 1987), p. 48. 
TABLE XXIX

MEN AND EQUIPMENT OF SOVIET FRONTS

JUNE 20, 1944

\section{$1 \mathrm{st}$}

Men And 1st 3rd 2nd Belorussian

Equipment Baltic Belorussian Belorussian (rt. wing) Total

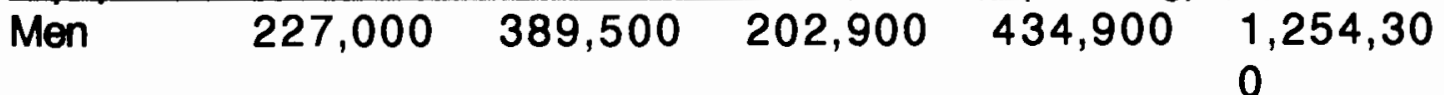

$\begin{array}{lllll}\text { Machine } \quad 8,432 & 13,214 & 5,750 & 16,035 & 43,431\end{array}$

Guns

Tanks

Assault 126

$1,169 \quad 102$

883

2,715

Guns

Anti-

778

641

174

414

1,355

Guns (45-

1,175

833

1,444

4,230

$57 \mathrm{~mm}$ )

Field

2,133

2,893

1,768

3,769

10,563

Guns

(76mm

and

larger)

Mortars

2,213

3,552

1,957

3,792

11,514

$(82 \mathrm{~mm}$

and

$120 \mathrm{~mm}$ )

MRLs

604

689

264

749

2,306

AAA Guns 420

792

329

762

2,303

Aircraft 902

1,864

528

2,303

5,327

Trucks

19,537

16,208

7,727

17,177

60,649

Source: Colonel T.N. Dupuy and Paul Martell, Great Battles on the Eastern Front: The Soviet-German War 1941-1945 (New York: The Bobbs-Merril Company, Inc., 1982), p. 157. 
TABLE $X X X$

SOVIET EFFECTIVE AIRCRAFT STRENGTH IN THE SOVIET AIR ARMIES PRIOR TO THE OPENING OF THE BELORUSSIAN OFFENSIVE

\begin{tabular}{|c|c|c|c|c|c|}
\hline Aircraft & \multicolumn{5}{|c|}{3 Air Army 1 Air Army 4 Air Armv 16 Air Army Total } \\
\hline Fighters & 403 & 767 & 196 & 952 & 2318 \\
\hline $\begin{array}{l}\text { Ground } \\
\text { Attack }\end{array}$ & 368 & 547 & 193 & 636 & 1744 \\
\hline Bombers & - & 392 & -- & 263 & 655 \\
\hline $\begin{array}{l}\text { Night } \\
\text { Bombers }\end{array}$ & 79 & 81 & 121 & 150 & 431 \\
\hline $\begin{array}{l}\text { Recon } \\
\text { Long } \\
\text { range } \\
\text { Bombers }\end{array}$ & 52 & 77 & 18 & 32 & $\begin{array}{r}179 \\
1007\end{array}$ \\
\hline $\begin{array}{l}\text { Total } \\
\text { Aircraft }\end{array}$ & 902 & 1864 & 528 & 2033 & 6334 \\
\hline
\end{tabular}

Source: Gerd Niepold, Battle For White Russia: The Destruction of Army Group Centre June 1944 (London: Brassey's Defense Publishers, 1987), p. 64. 
TABLE XXXI

OPERATIONAL DENSITY OF SOVIET TROOPS

ON THE BELORUSSIAN FRONT

\begin{tabular}{|c|c|c|c|c|c|c|}
\hline \multirow[b]{2}{*}{ Front } & \multicolumn{3}{|c|}{ Total Frontage } & \multicolumn{2}{|c|}{ Attack Sector } & \multirow[b]{2}{*}{$\begin{array}{r}\text { Density } \\
(\mathrm{km} / \text { div) }\end{array}$} \\
\hline & $\begin{array}{l}\text { Frontage } \\
(\mathrm{km})\end{array}$ & $\begin{array}{l}\text { Rifle Divs. } \\
\text { (no) }\end{array}$ & $\begin{array}{r}\text { Density } \\
\text { (km/div) }\end{array}$ & $\begin{array}{l}\text { Frontage } \\
(\mathrm{km})\end{array}$ & $\begin{array}{l}\text { Rifle Divs } \\
\text { (no) }\end{array}$ & \\
\hline 1 Baltic & 160 & 24 & 6.6 & 25 & 16 & 1.5 \\
\hline $\begin{array}{l}3 \text { Belo- } \\
\text { russian }\end{array}$ & 140 & 33 & 4.2 & 37 & 25 & 1.5 \\
\hline $\begin{array}{l}2 \text { Belo- } \\
\text { russian }\end{array}$ & 160 & 22 & 7.3 & 12 & 10 & 1.2 \\
\hline $\begin{array}{l}1 \text { Belo- } \\
\text { russian } \\
\text { (right) }\end{array}$ & 230 & 39 & 5.8 & 38 & 26 & 1.5 \\
\hline $\begin{array}{l}\text { Totall } \\
\text { Average }\end{array}$ & 690 & 118 & 5.8 & 112 & 77 & 1.46 \\
\hline
\end{tabular}

Source: Gerd Niepold, Battle For White Russia: The Destruction of Army Group Centre June 1944 (London: Brassey's Defense Publishers, 1987), p. 53. 
TABLE XXXII

SOVIET ATTACKING ECHELONS AGAINST

ARMY GROUP CENTER

\begin{tabular}{|c|c|c|c|c|}
\hline Front & $\begin{array}{l}\text { Armies } \\
\text { Within Front }\end{array}$ & $\begin{array}{l}\text { Corps } \\
\text { Within Armies }\end{array}$ & $\begin{array}{l}\text { Divisions } \\
\text { Within Corps }\end{array}$ & $\begin{array}{l}\text { Regiments } \\
\text { Within Divs }\end{array}$ \\
\hline 1st Baltic & 1 echelon & $\begin{array}{l}\text { 39th Army } \\
2 \text { echelons } \\
43 \text { rd Army } \\
1 \text { echelon }\end{array}$ & $\begin{array}{l}2 \text { echelons } \\
2 \text { echelons }\end{array}$ & $\begin{array}{l}1 \text { to } 2 \\
\text { echelons } \\
1 \text { to } 2 \\
\text { echelons }\end{array}$ \\
\hline \multirow[t]{4}{*}{$\begin{array}{l}\text { 3rd Belo- } \\
\text { russian }\end{array}$} & 1 echelon & $\begin{array}{l}39 \text { th Army } \\
2 \text { echelons }\end{array}$ & 2 echelons & 2 echelons \\
\hline & & $\begin{array}{l}\text { 5th Army } \\
1 \text { echelon }\end{array}$ & 2 echelons & 1 echelon \\
\hline & & $\begin{array}{l}\text { 11th Guards } \\
\text { Army } \\
1 \text { echelon }\end{array}$ & 2 echelons & 1 echelon \\
\hline & & $\begin{array}{l}\text { 31st Army } \\
1 \text { echelon }\end{array}$ & 2 echelons & 2 echelons \\
\hline \multirow{5}{*}{$\begin{array}{l}\text { 2nd Belo- } \\
\text { russian } \\
\text { 1st Belo- } \\
\text { russian } \\
\text { (right wing) }\end{array}$} & 1 echelon & $\begin{array}{l}\text { 49th Army } \\
1 \text { echelon }\end{array}$ & 3 echelons & 1 echelon \\
\hline & 1 echelon & $\begin{array}{l}\text { 3rd Army } \\
2 \text { echelons }\end{array}$ & 2 echelons & $\begin{array}{l}2 \text { to } 3 \\
\text { echelons }\end{array}$ \\
\hline & & $\begin{array}{l}\text { 48th Army } \\
1 \text { echelon }\end{array}$ & 2 echelons & 1 echelon \\
\hline & & $\begin{array}{l}\text { 65th Army } \\
1 \text { echelon }\end{array}$ & 2 echelons & 1 echelon \\
\hline & & $\begin{array}{l}\text { 28th Army } \\
1 \text { echelon }\end{array}$ & 2 echelons & 2 echelons \\
\hline
\end{tabular}

Source: Gerd Niepold, Battle For White Russia: The Destruction of Army Group Centre June 1944 (London: Brassey's Defense Publishers, 1987), p. 54. 
TABLE XXXIII

SOVIET ARMORED DENSITY OPPOSITE

ARMY GROUP CENTER,

JUNE 20, 1944

\begin{tabular}{|c|c|c|c|c|c|c|c|}
\hline \multirow[b]{2}{*}{ Fronts } & \multicolumn{2}{|c|}{ Frontage (km) } & \multicolumn{3}{|c|}{ Tanks \& SU Guns } & \multicolumn{2}{|c|}{ Density (AFVs/km) } \\
\hline & Total & $\begin{array}{l}\text { Attack } \\
\text { Sector }\end{array}$ & Total & $\begin{array}{l}\text { Attack } \\
\text { Sector }\end{array}$ & $\%$ Total & Overall & $\begin{array}{l}\text { Attack } \\
\text { Sector }\end{array}$ \\
\hline $\begin{array}{l}1 \mathrm{st} \\
\text { Baltic }\end{array}$ & 160 & 25 & 687 & 535 & 77.8 & 4 & 22 \\
\hline $\begin{array}{l}3 \text { rd } \\
\text { Belo- } \\
\text { russia }\end{array}$ & 140 & 33 & 1810 & 1466 & 80.9 & 13 & 44 \\
\hline $\begin{array}{l}\text { 2nd } \\
\text { Belo- } \\
\text { russia }\end{array}$ & 160 & 12 & 276 & 227 & 82.2 & 2 & 19 \\
\hline $\begin{array}{l}1 \text { st } \\
\text { Belo- } \\
\text { russia } \\
\text { (right) }\end{array}$ & 230 & 29 & 1297 & 1297 & 100.0 & 5.6 & 45 \\
\hline $\begin{array}{l}\text { Totall } \\
\text { Aver. }\end{array}$ & 690 & 99 & 4070 & 3525 & 86.6 & 5.9 & 35.6 \\
\hline
\end{tabular}

*SU Guns are assault guns or self-propelled guns.

Source: Gerd Niepold, Battle For White Russia: The Destruction of Army Group Centre June 1944 (London: Brassey's Defense Publishers, 1987), p. 60. 
TABLE XXXIV

SOVIET ARTILLERY DENSITY AND FRONTAGES

OPPOSTTE ARMY GROUP CENTER,

JUNE 20, 1944

\begin{tabular}{|c|c|c|c|c|c|c|c|}
\hline \multirow[b]{2}{*}{ Fronts } & \multicolumn{2}{|c|}{ Frontage (km) } & \multicolumn{2}{|c|}{ Guns \& Mortars } & & \multicolumn{2}{|c|}{ Density (Tubes/km } \\
\hline & Total & $\begin{array}{l}\text { Attack } \\
\text { Sector }\end{array}$ & Total & $\begin{array}{l}\text { Attack } \\
\text { Number }\end{array}$ & $\%$ Total & Overall & $\begin{array}{l}\text { Attack } \\
\text { Sector }\end{array}$ \\
\hline $\begin{array}{l}\text { st } \\
\text { Baltic }\end{array}$ & 160 & 25 & 4,950 & 3,768 & 76.1 & 31 & 151 \\
\hline $\begin{array}{l}\text { 3rd } \\
\text { Belo- } \\
\text { russia }\end{array}$ & 140 & 33 & 7,134 & 5,764 & 80.1 & 51 & 175 \\
\hline $\begin{array}{l}\text { 2nd } \\
\text { Belo- } \\
\text { russia }\end{array}$ & 160 & 12 & 3,989 & 2,168 & 54.3 & 30 & 181 \\
\hline $\begin{array}{l}1 \text { st } \\
\text { Belo- } \\
\text { russia } \\
\text { (right) }\end{array}$ & 230 & 29 & 8,310 & 5,929 & 71.3 & 36 & 204 \\
\hline $\begin{array}{l}\text { Totall } \\
\text { Aver. }\end{array}$ & 690 & 99 & 24,383 & 17,629 & 72.3 & 35 & 178 \\
\hline
\end{tabular}

"Multiple Rocket Lauchers are included in figures.

Source: Gerd Niepold, Battle For White Russia: The Destruction of Army Group Centre June 1944 (London: Brassey's Defense Publishers, 1987), p. 60. 


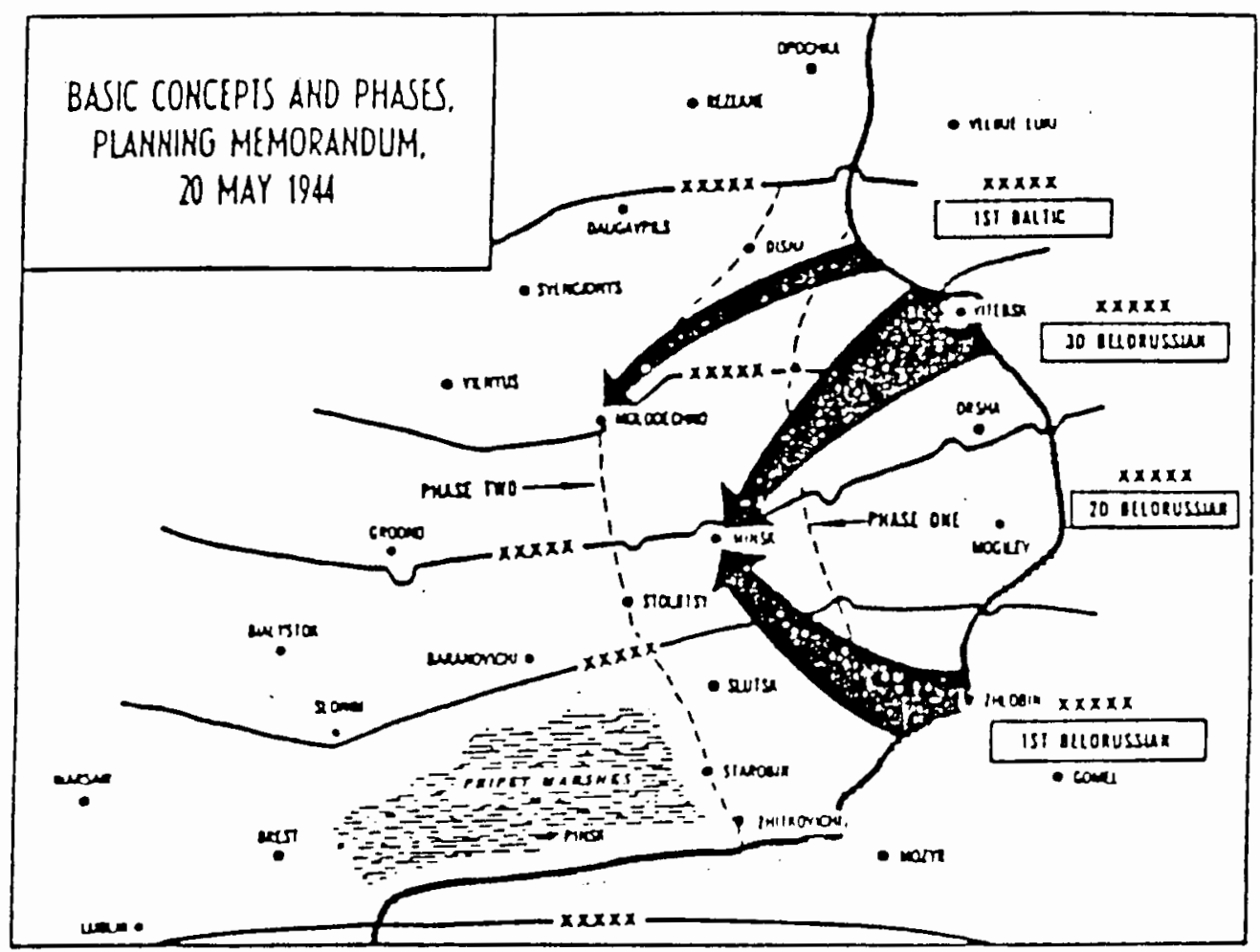

Figure 51. Basic Concepts And Phases, Planning Memorandum, 20 May 1944. Source: Lt. Colonel Charles G. Fitzgerald, "Operation Bagration," Military Review, Vol. XLIV, No. 5, May 1964, p. 64. 


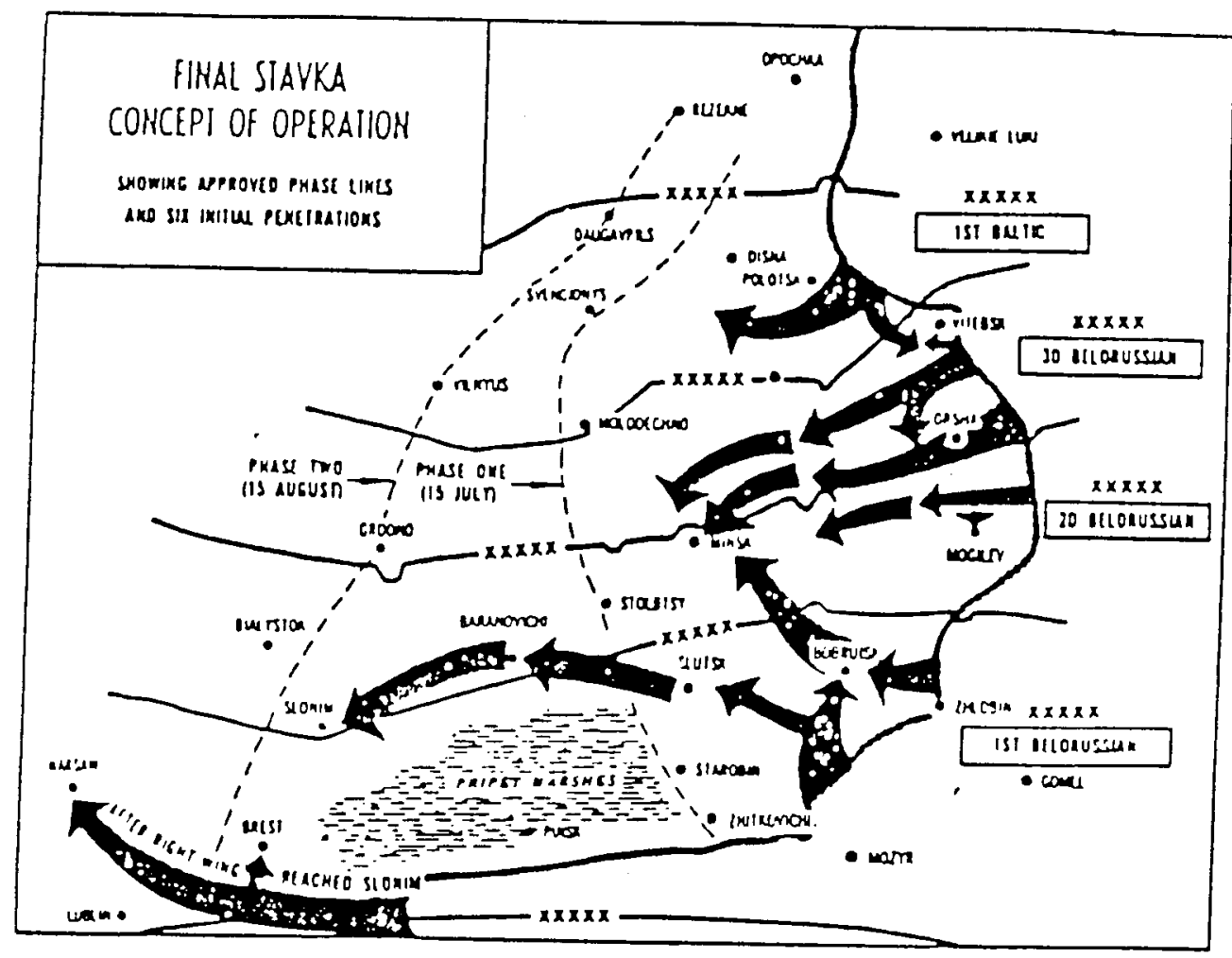

Figure 52. Final Stavka Concept Of Operation. Source: Lt. Colonel Charles G. Fitzgerald, "Operation Bagration," Military Review, Vol. XLIV, No. 5, May 1964, p. 65. 


\begin{tabular}{|c|c|c|c|c|c|}
\hline \multicolumn{6}{|c|}{ MAJOR ELEMENTS OF FRONT PLANS } \\
\hline Front & $\begin{array}{l}\text { Tolal } \\
\text { Widlh of } \\
\text { Frontage } \\
\text { (kilo- } \\
\text { meter) }\end{array}$ & $\begin{array}{c}\text { H'idth } \\
\text { of } \\
\text { Penetra- } \\
\text { fion } \\
\text { (kilo- } \\
\text { meter) }\end{array}$ & $\begin{array}{c}\text { Formations } \\
\text { Haking } \\
\text { Penetrations }\end{array}$ & $\begin{array}{c}\text { Exploilation } \\
\text { Force }\end{array}$ & Remark. \\
\hline $\begin{array}{l}\text { Ist } \\
\text { Baltic }\end{array}$ & 160 & 25 & $\begin{array}{l}\text { 6th Guards } \\
\text { Army; } 43 d \\
\text { Army } \\
\end{array}$ & $\begin{array}{l}\text { 1st Tank } \\
\text { Corps }\end{array}$ & \\
\hline $\begin{array}{l}\text { Jd } \\
\text { Belorussian }\end{array}$ & 130 & 15 & $\begin{array}{l}\text { a. Northern } \\
\text { Shock } \\
\text { Group } \\
\text { 3yth Army; } \\
\text { Bth Army } \\
\\
\text { b. Southern } \\
\text { Shock } \\
\text { Group } \\
\text { 11th Guards } \\
\text { Army: 31st } \\
\text { Army }\end{array}$ & $\begin{array}{l}\text { Mechanized } \\
\text { Cavalry } \\
\text { Group (3d } \\
\text { Cavalry and } \\
\text { 3d Cuards } \\
\text { Mechanized } \\
\text { Corps) } \\
\text { 2d Guards } \\
\text { Tank Corps }\end{array}$ & $\begin{array}{l}\text { 5th Guards Tank } \\
\text { Army to be com- } \\
\text { mitted as the } \\
\text { front's main ex- } \\
\text { ploiting force in } \\
\text { zone of group } \\
\text { enjoying greater } \\
\text { saccess }\end{array}$ \\
\hline $\begin{array}{l}\text { 2d } \\
\text { Belorugsian }\end{array}$ & 160 & .15 & 49th Army & $\begin{array}{l}\text { 1st Rifle } \\
\text { Corps }\end{array}$ & $\begin{array}{l}\text { Initially, this } \\
\text { front had limited } \\
\text { objective of seiz- } \\
\text { ing Mogilev }\end{array}$ \\
\hline $\begin{array}{l}\text { let } \\
\text { Belorussian }\end{array}$ & $\begin{array}{c}650 \\
(250)\end{array}$ & 16 & $\begin{array}{l}\text { a. Northern } \\
\text { Shock } \\
\text { Group } \\
\text { 3d Army: } \\
\text { 48th Army } \\
\text { 6. Southern } \\
\text { Shock } \\
\text { Group } \\
\text { 65th Army: } \\
\text { 28th Army } \\
\text { Mechanized } \\
\text { Cavalry } \\
\text { Group }\end{array}$ & $\begin{array}{l}\text { 9th Tank } \\
\text { Corps } \\
\text { 1st Guards } \\
\text { Tank Corps }\end{array}$ & $\begin{array}{l}\text { Initially, only } \\
\text { right wing of } \\
\text { this front (four } \\
\text { armies) were to } \\
\text { be committed } \\
\text { Four a rmies had } \\
\text { a frontage of } \\
250 \text { kilometers. }\end{array}$ \\
\hline
\end{tabular}

Figure 53. Major Elements Of Front Plans. Source: Lt. Colonel Charles G. Fitzgerald, "Operation Bagration," Military Review, Vol. XLIV, No. 5, May 1964, p. 67. 


\section{TIME TABLE: OPERATION BAGRATION}

17.1J April Simlint transmitted directives to all fiont commanders to usiume the defense.

Jo April Starlia completed initial diaft of concept of operation.

Plaming directives based on Stavia concept issued to front commadiders.

$15 \mathrm{Maly}$

Four front commanders submitled their plans to sfortite.

:0 May

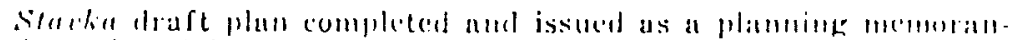

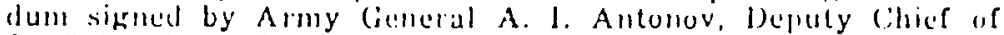
Staff for Operations of the Cieneral Stalf of the Red Army and Navy.

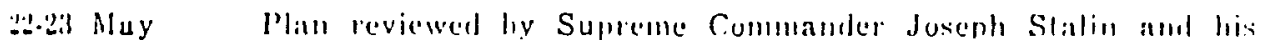
depulies ulung with the four front commanders and their thiefs of stall.

It:i10 May Sfama revised draft plan.

II Misy

Slavka issued revised planning directives to front commanters.

1 J June Fivit plans finalized and reviewed by Stalkil.

?u June

By this date the four frontis had received all their reinfurcing troopls ant compleced training.

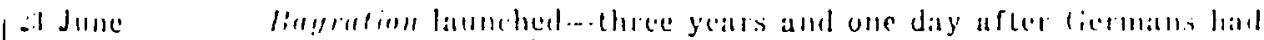
first allaclical Belorussia.

Figure 54. Time Table: Operation Bagration. Source: Lt. Colonel Charles G. Fitzgerald, "Operation Bagration," Military Review, Vol. XLIV, No. 5, May 1964, p. 67. 


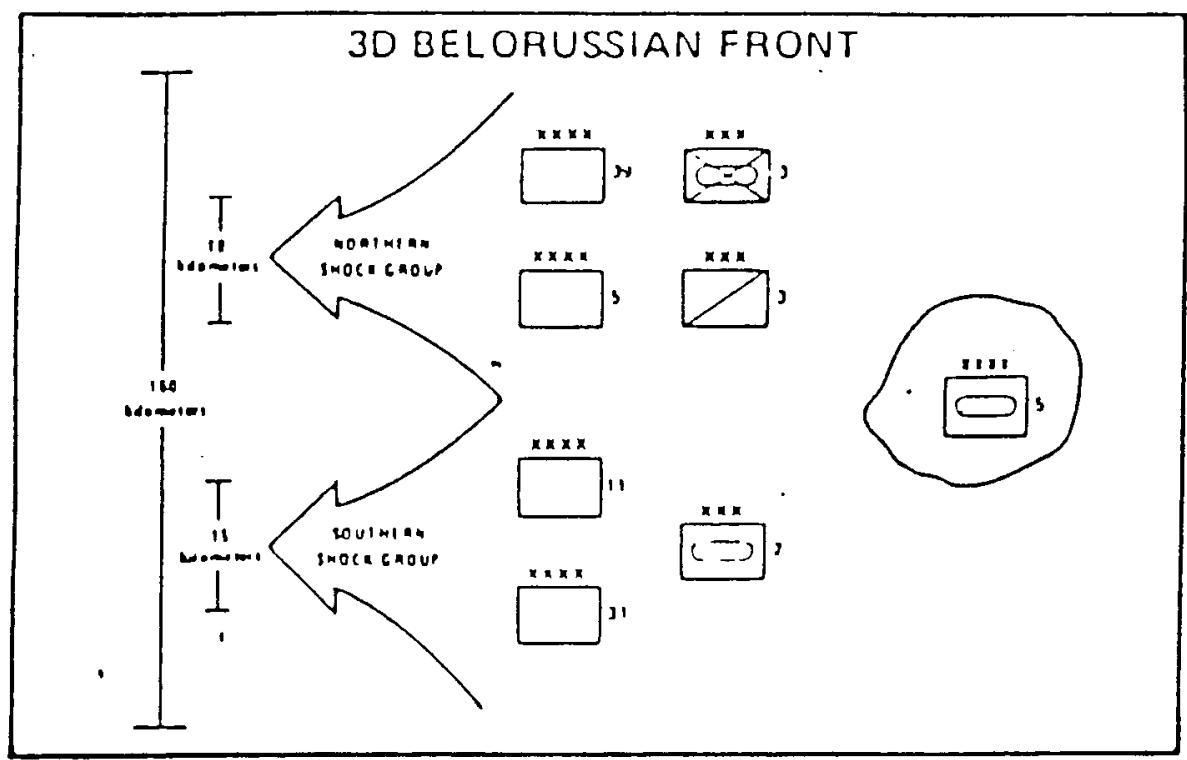

Figure 55. 3rd Belorussian Front Shock Groups. Source: Major Joseph C. Arnold, "Current Soviet Tactical Doctrine: A Reflection of the Past," Military Review Vol. 57, July 1977, p. 20. 


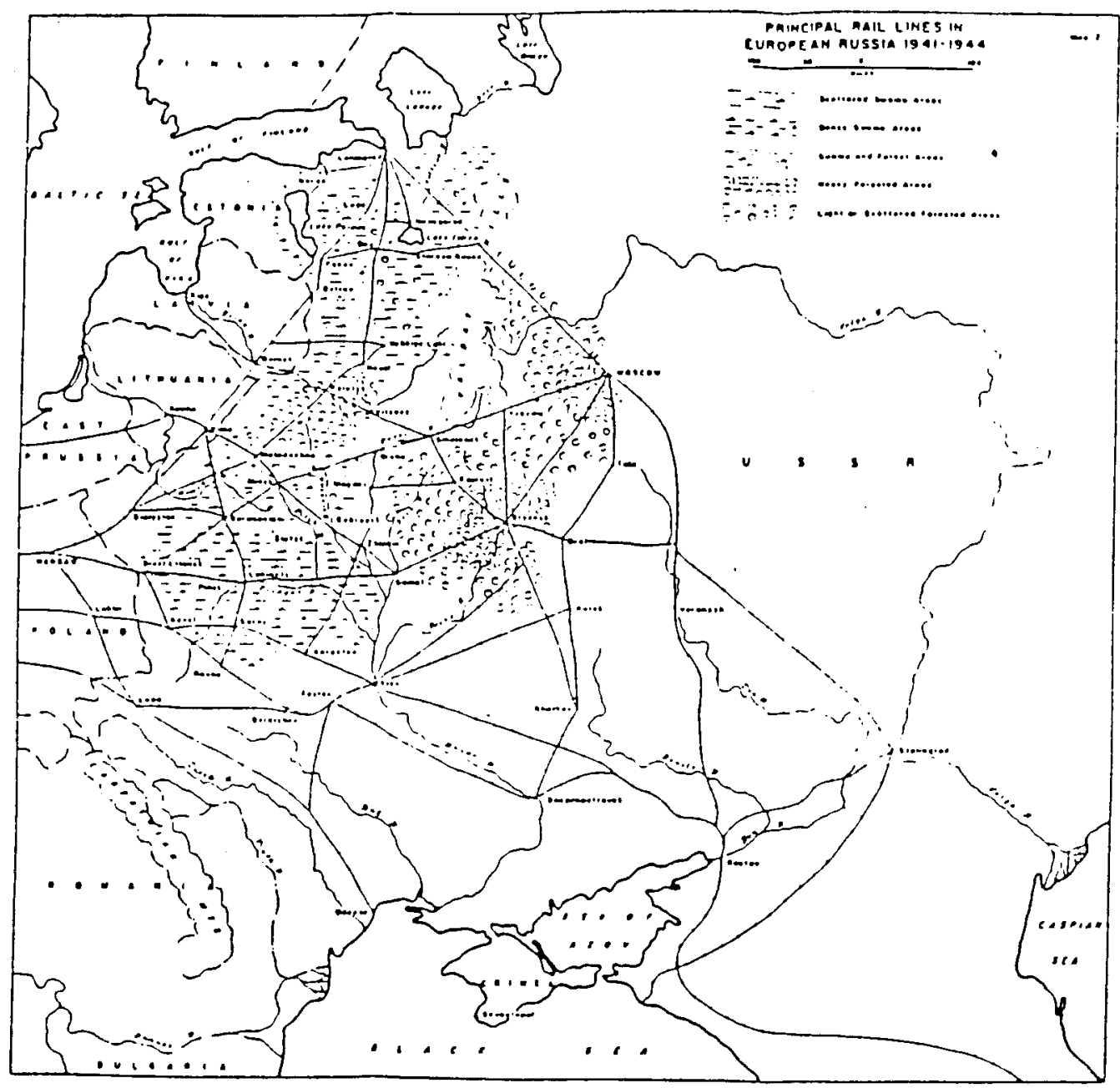

Figure 56. Principal Rail Lines in European Russia 1941-1944. Source: Edgar M. Howell, The Soviet Partisan Movement 1941-1944 (Washington, D.C.: Department of the Army, August 1956), Map 2. 


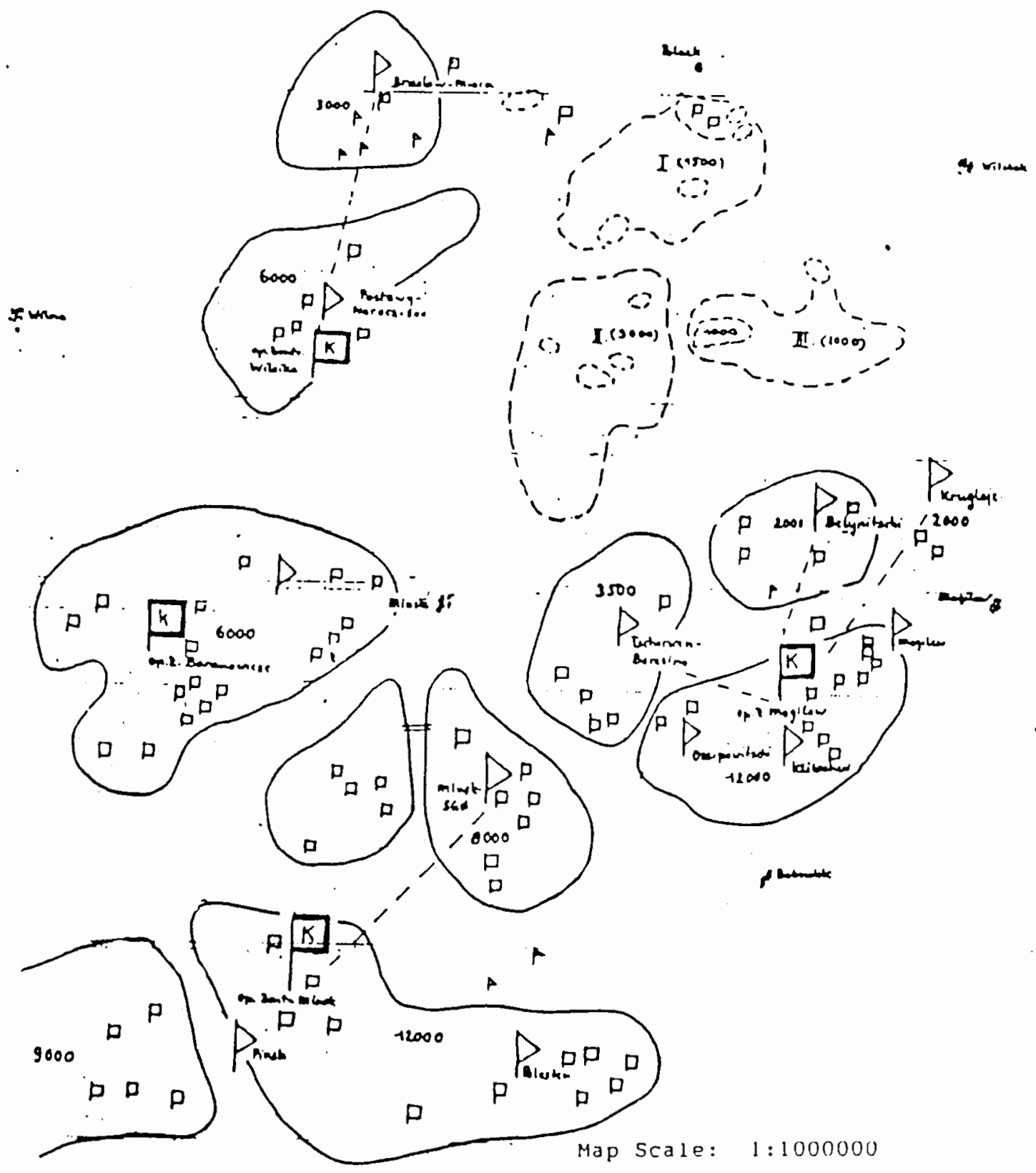

Figure 57. Partisan Situation June 1944. Source:

Bandenlagenkarte Std. Juni 44. Heeresgruppe Mitte National Archives Microfilm Publication T-311, Roll 219. 


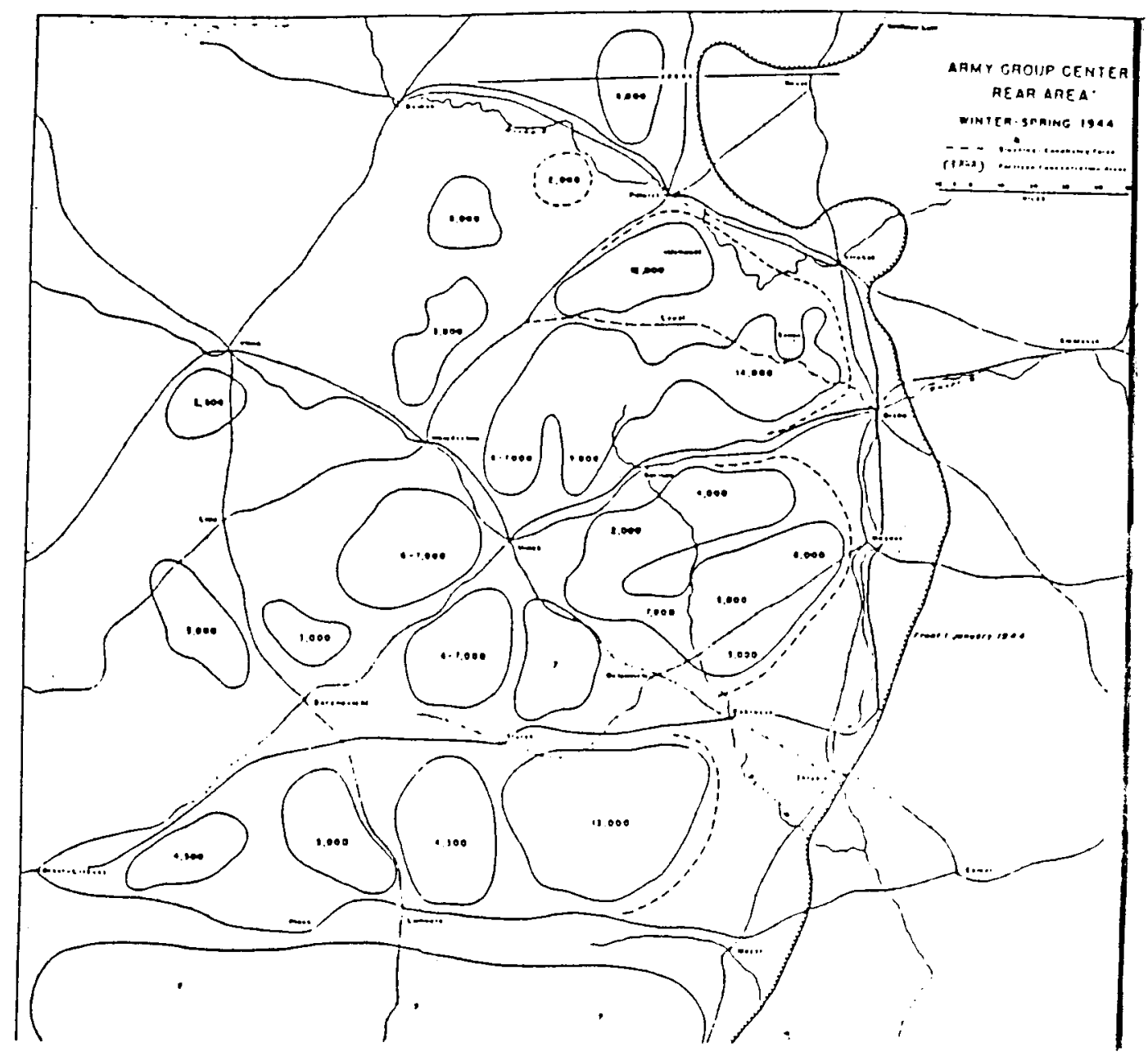

Figure 58. Partisans in the Army Group Center Rear Area, November 1943-March 1944. Source: Edgar M. Howell, The Soviet Partisan Movement 1941-1944 (Washington, D.C.: Department of the Army, August 1956), Map 9. 


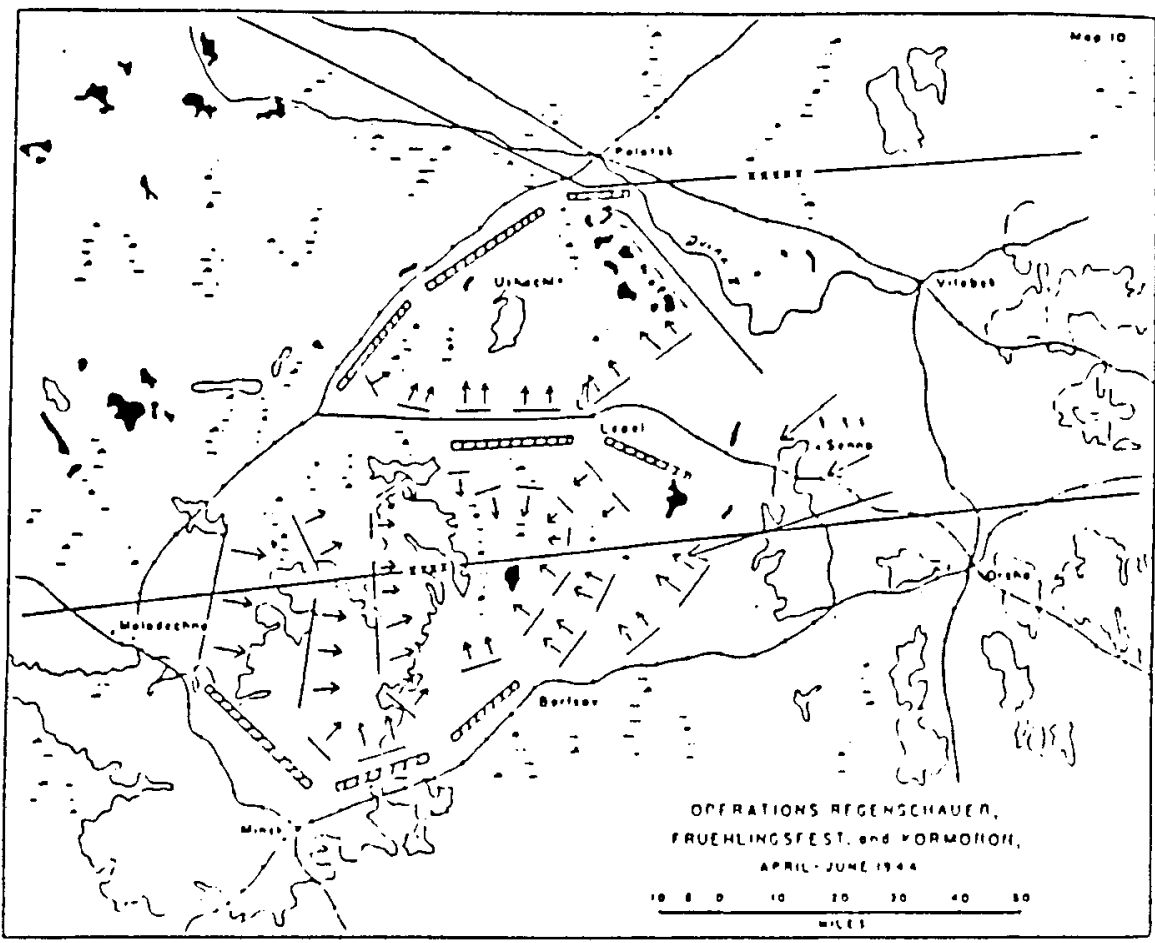

Figure 59. Operations Regenschauer, Fruehlingsfest, and Kormoron, April-June 1944. Source: Edgar M. Howell, The Soviet Partisan Movement 1941-1944 (Washington, D.C.: Department of the Army, August 1956), Map 10. 


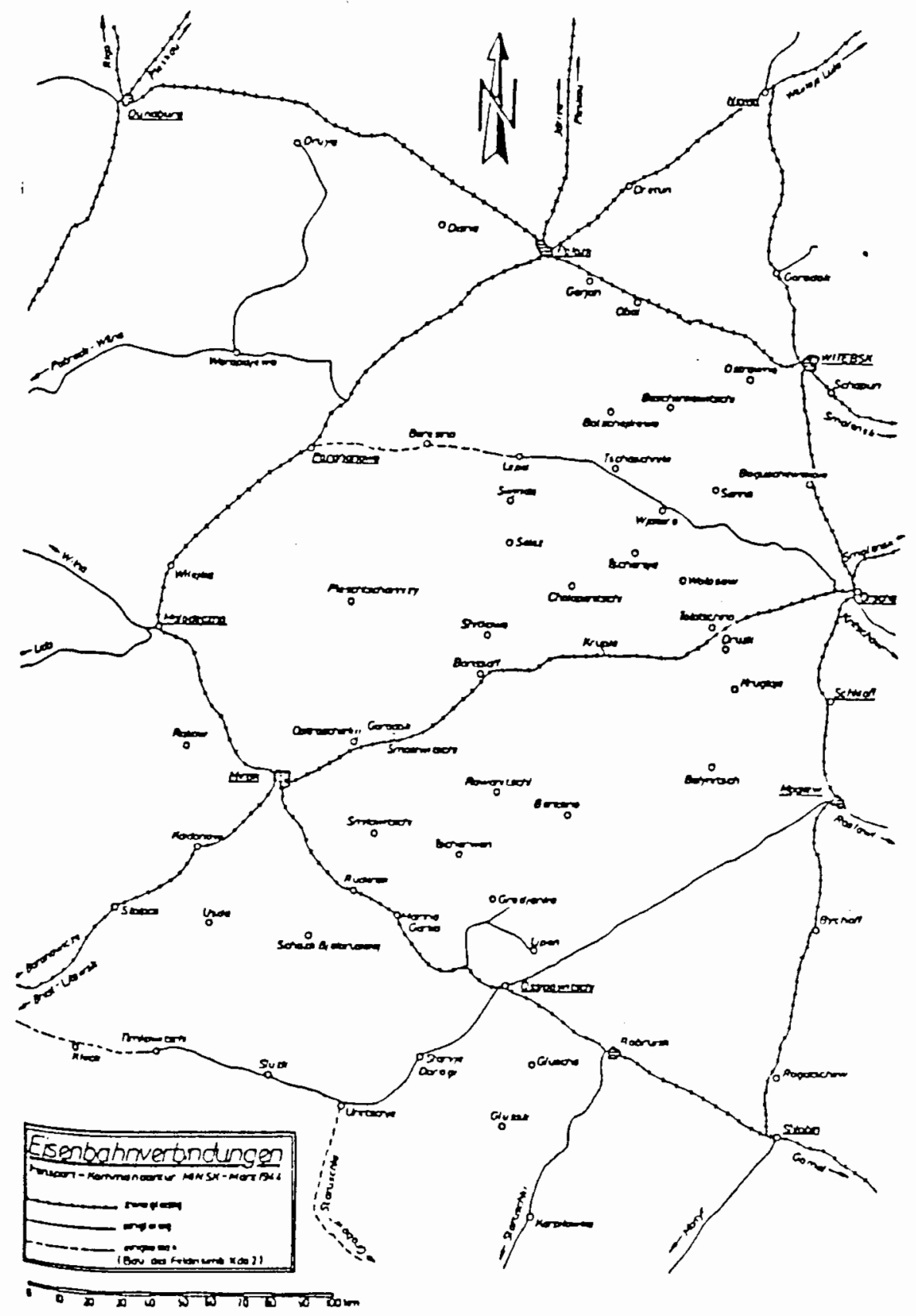

Figure 60. Rail Lines Behind Army Group Center. Source: Rolf Hinze, Der Zusammenbruch der Heeresgruppe Mitte Im Osten 1944 (Stuttgart: Motorbuch Verlag, 1980), p.21. 


\section{FORCE RELATIONSHIPS}

Troop strength

Rifle and cavalry divisions (based on 43 German divisions between Lake Neshcherdo and Mozyr)

Artillery and mortars (76-millimeter and above)

Tanks and self-propelled guns

Combat aircraft

\begin{tabular}{ccc} 
Soviet & \multicolumn{2}{c}{ Germo } \\
2 & $:$ & 1 \\
3 & $:$ & 1 \\
2.9 & $:$ & 1 \\
4.3 & $:$ & 1 \\
4.5 & $:$ & 1
\end{tabular}

SOVIET FRONT SUPERIORITY

$\begin{array}{cccc}\begin{array}{c}\text { lst } \\ \text { Baltic }\end{array} & \begin{array}{c}3 d \\ \text { Belorussian } \\ \text { (on both oxes } \\ \text { of main enort) }\end{array} & \begin{array}{c}\text { 2d } \\ \text { Belorussian }\end{array} & \begin{array}{c}\text { Ist } \\ \text { Belorussian }\end{array} \\ 3: 1 & 2.2: 1 & 2: 1 & 3: 1 \\ 3: 1 & 2.3: 1 & 2: 1 & 3: 1 \\ 6: 1 & 10: 1 & 4: 1 & 10: 1 \\ 6: 1 & 7.7: 1 & 5: 1 & 8: 1\end{array}$

Figure 61. Soviet-German Force Relationships And Soviet Front Superiority. Source: Lt. Colonel Charles G. Fitzgerald, "Operation Bagration," Military Review, Vol. XLIV, No. 5, May 1964, pp. 68-69. 


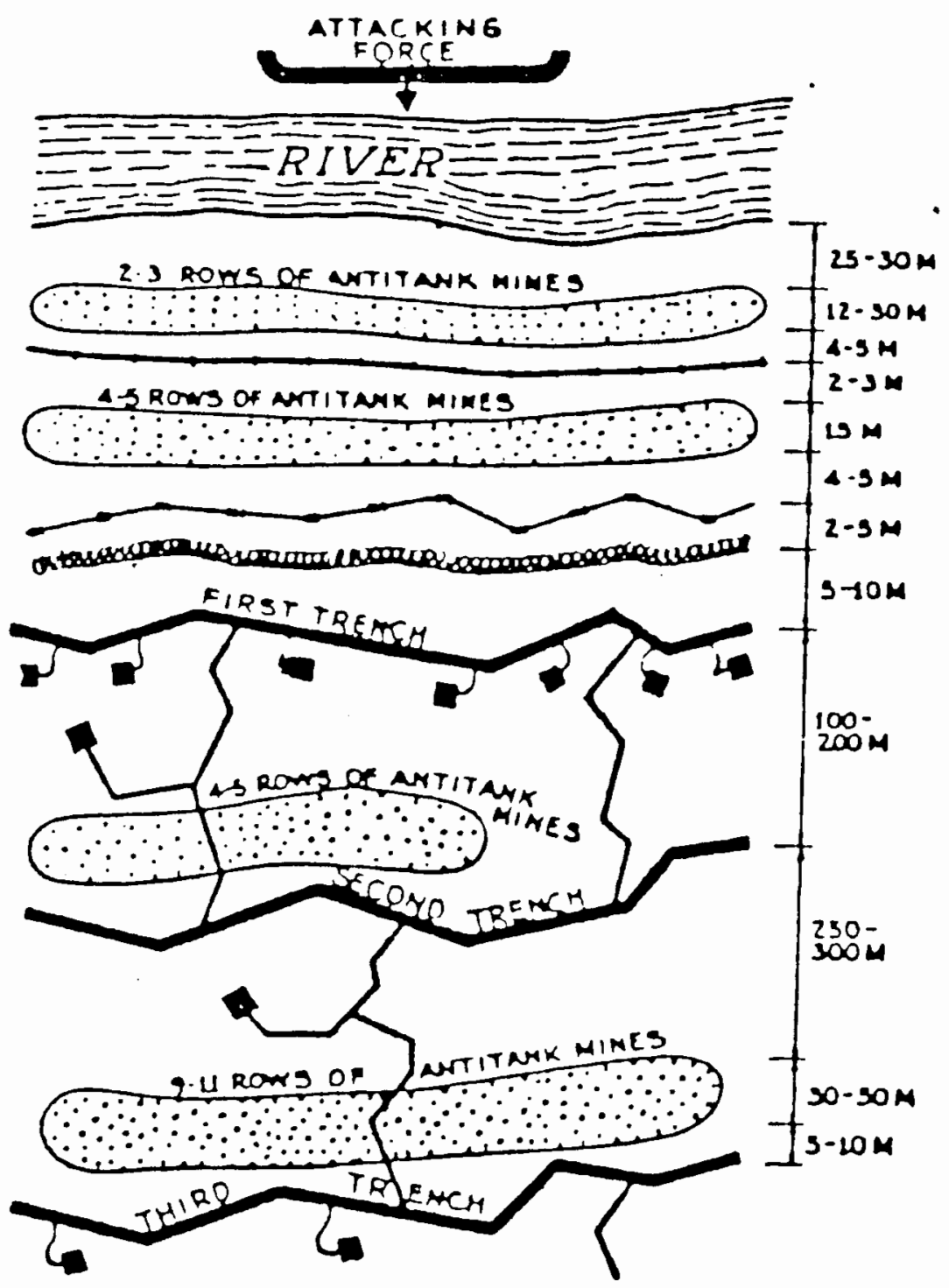

Figure 62. German River Defensive Position on the Eastern Front. Source: Major J. Galkin, "Notes on German Field Fortifications," Tekhnika Molodezhi April 1944 as translated in Military Review Vol. XXV, No. 4, July 1945, p. 102. 


\section{NOTES TO CHAPTER VIII}

1P.N. Pospelov et al, p. 247.

2lbid.

3 ibid., p. 300

${ }^{4}$ S.M. Shtemenko, The Soviet General Staff At War 1941-1945 Vol. 1 (Moscow: Progress Publishers, 1985), p. 311; Nigel Nicoison, Napoleon 1812 (New York:

Harper \& Row Publishers, 1985), pp. 71-76.

5P.N. Pospelov et al, p.301

Glbid.

7Lt. Colonel Charles G. Fitzgerald, "Operation Bagration," Military Review May 1964, p. 62.

8P.N. Pospelov et al, p. 302.

${ }^{9}$ Fitzgerald, "Operation Bagration," p. 62.

10 Ibid., p. 63.

${ }^{11}$ lbid.

12 bid.

13P.N. Pospelov et al, p. 302.

14/bid.

15Ibid., pp. 302-303.

16/bid., p. 303.

${ }^{17}$ Ibid.

$18 \mathrm{lbid}$.

19 bid., p. 304.

20lbid.

21 Ibid. 
22Fitzgerald, "Operation Bagration," p. 68.

23P.N. Pospelov et al, p. 305.

${ }^{24}$ Ibid.; Fitzgerald, p. 68.

${ }^{25}$ Fitzgerald, p. 66

${ }^{26}$ Ibid., pp.66-67

27P.N. Pospelov et al, p.250.

28/bid, p. 305

29 ibid.

30 Ibid., p. 306.

$31 \mathrm{lbid}$.

32/bid.

33lbid.

${ }^{34}$ Ibid.

35Ibid., pp.306-307.

36 Ibid., p. 307.

37Ibid.

38 Ibid., p. 309.

39 lbid., p. 308.

40Ibid.

${ }^{41}$ lbid.

42!bid., p. 309.

43lbid., p. 306.

44!bid., p. 307. 
45 ibid.

46|bid., p. 310

47|bid., p. 309.

48 Ibid.

49 Ibid., p. 304; M.N. Kozhevnikov, The Command and Staff of Soviet Army Air Force in the Great Patriotic War 1941-1945 (Moscow: Nauka Publishing House, 1977), p. 157.

50 lbid.

${ }^{51}$ M.N. Kozhevnikov, p. 154.

52 ibid.

53|bid., p. 155.

54 Ibid.

55 ibid., p. 156.

56/bid.

57 Ibid.

58 Ibid.

${ }^{59}$ Department Of The Army, Rear Area Security In Russia: The Soviet Second Front Behind The German Lines (Washington, D.C.: Department Of The Army , July 1951), p. 24.

60P.N. Posepelov et al, p. 318.

${ }^{61}$ Edgar M. Howell, The Soviet Partisan Movement 1941-1944 (Washington, D.C.: Department Of The Army, August 1956), p. 104.

62Department Of The Army, Russian Combat Methods in World War II (Washington, D.C.: Department Of The Army, 1950), p. 104.

63lbid., p. 105.

64P.N. Pospelov et al, p. 318. 
65Ibid.

66Hermann Teske, Die Silbernen Spiegel (Heidelberg: Kurt Vowinckel Verlag, 1952), p. 218.; John A Armstrong, Soviet Partisans in World War II (Madison:

University of Wisconsin Press, 1964), p. 739; Hermann Gackenholz, "The Collapse of Army Group Centre in 1944," Decisive Battles of World War 11: The German View (New York: G.P. Putnam's Sons, 1965), p. 364; Howell, p. 201.

67Department Of The Army, Rear Area Security in Russia: The Soviet Second Front Behind The German Lines, p. 30.

68Teske, p. 218.

69 lbid.

70Department Of The Army, Rear Area Security In Russia: The Soviet Second Front Behind The German Lines, p. 30.

${ }^{71}$ Kdr. d. Eisb. Pi. Brigade 2 (bei H. Gr. Mitte) Lage Meldung 20.6.44. NAMP T-78, Roll 113.

72Kdr. d. Eisb. Pi. Brigade 2 (bei H. Gr. Mitte) Lage Meldung 22.6.44. NAMP T-78, Roll 113.

73Kdr. d. Eisb. Pi. Brigade 2 (bei H. Gr. Mitte) Lage Meldung 21.6.44. NAMP T-78, Roll 113.

${ }^{74} \mathrm{Kdr}$. d. Eisb. PI. Brigade 2 (bei H. Gr. Mitte) Lage Meldung 23.6.44. NAMP T-78, Roll 113.

75Howell, p. 209.

76 ibid.

77 Ibid.

78 bid.

${ }^{79}$ Colonel T.N. Dupuy and Paul Martell, Great Battles on the Eastern Front: The Soviet-German War 1941-1945 (New York: The Bobbs-Merril Company, Inc., 1982), p. 155.

80 lbid., p. 157.

${ }^{81}$ P.N. Pospelov et al, p. 239. 
82Ibid.

83Mehner, GHTBDW Vol. 10, p.502.

${ }^{84}$ Niepold, Battle For White Russia: The Destruction of Army Group Centre June 1944, p. 28.

85 bid.

86 lbid.

87 Ibid., p. 32.

88 ibid.

${ }^{89}$ Brigadier General N.E. Chibisov, "Military Doctrine of the Red Army," Krasnaia Zvezda (Red Star) 12 November 1944 as translated in Military Review Vol. 25, No. 5, August 1945, p. 90.

90Niepold, Battle For White Russia: The Destruction of Army Group Centre June 1944, pp. $28 \& 53$.

${ }^{91}$ Chibisov, p. 92.

92Niepold, Battle For White Russia: The Destruction of Army Group Centre June 1944, pp. 58-59.

93/bid., p. 59.

94!bid.

95Ibid.

96/bid., p. 63.

97|bid.

98/bid., p. 60; Colonel T.N. Dupuy and Paul Martell, Great Battles On The Eastern Front: The Soviet-German War 1941-1945 (New York: The Bobbs-Merrill Company, Inc., 1982), p. 162.

${ }^{99}$ Chris Bellamy, Red God of War: Soviet Artillery And Rocket Forces (New York: Brassey's Defense Publishers, 1986), p. 58; Fitzgerald, p. 68.

${ }^{100}$ Fitzgerald, p. 68. 
${ }^{101}$ Niepold, Battle For White Russia: The Destruction of Army Group Centre June 1944, p. 59.

102 bid.

103/bid., p. 60; Fitzgerald, p. 68; Dupuy and Martell, Great Battles On The Eastern Front: The Soviet-German War 1941-1945, p. 162.

104Niepold, Battle For White Russia: The Destruction of Army Group Centre June 1944, p. 62.

105 Ibid.

${ }^{106}$ ibid.

107/bid.

${ }^{108}$ Chibisov, p. 91.

${ }^{109}$ Niepold, Battle For White Russia: The Destruction of Army Group Centre June 1944, p. 56.

110 bid.

111 lbid., p. 54.

112 bid.

113/bid., p. 55.

114 Ibid. 


\section{CHAPTER IX}

\section{THE COLLAPSE OF ARMY GROUP CENTER \\ IN THE SUMMER OF 1944}

The collapse of Army Group Center was the most decisive blow inflicted on the German Army during the summer of 1944. The collapse of Army Group Center precipitated the defeats and collapses elsewhere on the Eastern Front. It was necessary to fill the vacuum left by the collapse of Army Group Center with the transfer of 46 divisions and 4 brigades to Belorussia. ${ }^{1}$ This transfer of military units weakened the remaining three army groups on the Eastern Front and set the stage for their subsequent retreat or defeat.

Furthermore, the collapse of Army Group Center was a catastrophe of an unprecedented scale in the East. The annihilation of Army Group Center resulted in the destruction of 28 divisions and the loss of more than 350,000 men. ${ }^{2}$ Hermann Gackenholz, an historian and the officer in charge of the war diary for Army Group Center during 1944-1945, stated that this disaster "was twice as great as the Stalingrad disaster." ${ }^{\text {3 }}$ The German 6th Army destroyed at Stalingrad contained only 4 army corps, 1 Panzer corps, 14 infantry divisions, 3 motorized divisions, 3 Panzer divisions, 1 
Rumanian infantry division, and 1 Rumanian cavalry division. 4 The 6th Army had approximately 300,000 men but only 220,000 were encircled with 100 tanks, 18,000 guns and 10,000 vehicles. $^{5}$ In the final collapse of the 6th Army 1 Field Marshal, 24 Generals and 90,000 men were taken prisoner but only after having resisted while surrounded in the asiatic cold from November 22, 1942 till January 31, 1943.6 The 6th Army had resisted total collapse for more than two months compared to Army Group center which collapsed in less than three weeks during the summer of 1944 with losses of 31 Generals and 350,000 to 400,000 men. $^{7}$

On July 18, 1944, the Organization Section of Army Group Center issued a report on the losses of Army Group Center from the period June 22, 1944 to July 15, 1944. The wounded and sick that were transported off the front amounted to $100,000.8$ The number of missing and dead were calculated at 300,000.9 The standing strength of the Army Group had fallen by at least 400,000 men since the beginning of the Soviet major offensive. 10 Therefore, the collapse of Army Group Center was the single most significant defeat of the German Army in the summer of 1944 and represents the first stage of a collapse of the German Army in the East.

In contrast, the Anglo-American forces had been bogged down in Normandy since June 6, 1944. The American forces did take the port of Cherbourg by July 1, 1944 inflicting losses on the Germans of 47,070 in killed, wounded or captured soldiers. ${ }^{11} 6$ German generals and 826 officers were also captured in this operation. 12 It was not until August 19th that Anglo-American forces had 
encircled the remnants of the German 5th Panzer and 7th Armies in the Falaise pocket. ${ }^{13}$ The allies had failed to close the pocket tightly and even with total air superiority elements of six or seven Panzer divisions managed to breakout of the Mortain-Falaise encirclement. ${ }^{14}$ However, the Germans did suffer the loss of 50,000 killed and 200,000 captured. ${ }^{15}$ Nevertheless, the AngloAmerican victories while important in the West were still not as large as the enormous Soviet victories in the East which inflicted staggering losses on the German Army throughout the summer of 1944.

Soviet and German sources disagree on the date of the beginning of "Operation Bagration." The German accounts claim that "Bagration" started on June 22, 1944.16 The Soviet accounts claim "Bagration" started on June 23, 1944.17 The differences are based upon the Soviet reconnaissance conducted in battalion strength by the 1st Baltic Front and the 3rd Belorussian Front on June 22, 1944.18 The Germans claim that this constituted the beginning of the major offensive while the Soviets claim that the following day, June 23, 1944, was the beginning of "Operation Bagration." The staggering of the six offensive thrusts (see Figure 63) into Army Group Center created some confusion as to when the overall offensive began. The analysis for the purpose of this study will examine the collapse of Army Group Center beginning on June 22, 1944.

The forces of Army Group Center (see Table XXXV) faced the reinforced strength of four Soviet Fronts: 1st Baltic, 3rd 
Belorussian, 2nd Belorussian, and 1st Belorussian. The 1st Baltic and the 3rd Belorussian Fronts initiated a reconnaissance in force to ascertain the strength of the German defenses and identify German gun positions. The 3rd Panzer Army and the 4th Army bore the brunt of the Soviet reconnaissance before the main offensive began on June 23, 1944 (see Figure 64).

$$
\text { JUNE 22, } 1944
$$

\section{3rd Panzer Army}

The 3rd Panzer Army commanded by Colonel General Reinhardt consisted of 3 corps: IX Corps, LIII Corps, and VI Corps (see Figure 65). These 3 corps contained approximately 9 infantry divisions (see Figure 65). The 3rd Panzer Army also had two more infantry divisions in reserve (see Figure 65). The IX Corps held the sector northwest of Vitebsk; the LIII Corps held the enclave containing Fortress Vitebsk; and the VI Corps held the sector south of Vitebsk (see Figure 64).

The 1st Baltic Front began the attack in the early morning beginning with a 24 minute artillery barrage. ${ }^{19}$ The reconnaissance detachments of the 6th Guards and 43rd Armies attacked the IX Corps front with strong armored and tactical air support. 20 The Soviets main effort was directed at Sirotino and both sides of Obol. The Germans estimated at least 6 Soviet divisions were attacking. ${ }^{21}$ The Soviets achieved an 8 kilometer wide and 5 kilometer deep penetration of the 252nd Infantry Division's front 
(see Figure 66).22 In the VI Corps sector the Soviets managed a breakthrough in the 299th Infantry Division's sector. This breakthrough to the south was widened up to $3 \mathrm{~km}$ (see Figure 67).

The situation was regarded seriously by $\mathrm{OKH}$ and the 24th Infantry Division and Assault Gun Brigade 909 were transferred from Army Group North to the 3rd Panzer Army to clear up the breakthrough at Obol.23 Even the 201st Security Division was ordered to commit no further units to the anti-partisan Operation "Kormoran" and security regiment 606 was placed at the disposal of the 3rd Panzer Army.24

IX Army Corps. A tactical withdrawal at Sirotino could improve the defensive situation, but Field Marshal Busch forbid the IX Corps Commander, General of Artillery Wuthmann from executing any withdrawals. General Wuthmann requested to withdraw to the secondary defense line, but Field Marshal Busch forbid it stating: "Sirotino must be held, abandon only under enemy pressure."25 Field Marshal Busch advised Wuthmann further that "nothing was to be abandoned that could be lost in battle."26 Field Marshal Busch was clearly applying Hitler's "stand fast" doctrine that would prove disastrous to Army Group Center. By evening the Soviets had achieved a penetration west of Sirotino $12 \mathrm{~km}$ wide and $7 \mathrm{~km}$ deep. ${ }^{27}$ Soviet air supremacy was demonstrated in the VI corps with 249 sorties and in the IX Corps with 381 sorties registered.28 
4th Army

The 4th Army was commanded by General of Infantry von Tippelskirch who had assumed command on June 5, 1944 since Colonel General Heinrici had become ill. ${ }^{29}$ The 4th Army consisted of 3 Corps: XXVII Corps, XXXIX Panzer Corps, and XII Corps (see Figure 68). These 3 corps contained 8 infantry divisions and 2 Panzer Grenadier divisions. The 4th Army reserve was the 286th Security Division and the Heavy Tank Battalion 501 which contained 29 Tiger tanks. ${ }^{30}$ The XXVII Corps covered the area north of Orsha, east of Orsha and south to the area of Gorki. The XXXIX Panzer Corps defended Mogilev and north to Gorki and east of Mogilev. The XII Corps extended south to the boundary of the 9th Army northeast of Bobruisk.

The Soviet attacks in the morning against the left flank of the XII Corps and the XXVII Corps in the sector of the 78th Assault Division were repulsed. In the XXXIX Panzer Corps the Soviets made a breakthrough on the left flank of the 110th Infantry Division near Gorki (see Figure 64). ${ }^{31}$ Soviet attacks were launched in the afternoon against the 78th Assault Division and the 25th Panzer Grenadier Division after heavy artillery preparation. A total of 3 regimental, 12 battalion and 9 company strength attacks supported by continuous close air support were repulsed.

\section{9th Army}

The 9th Army commanded by General of Infantry Jordan consisted of 3 Corps: XXXV Corps, XXXXI Panzer Corps, and LV Corps 
(see Figure 69). These 3 Corps contained 10 infantry divisions. The 9th Army had no reserve divisions at its disposal. But there were two Army Group reserve divisions in its operational area: the 20th Panzer Division and the 707th Infantry Division. The 9th Army boundary extended northeast from Bobruisk to the area northwest of Rogachev; and in the center to the east of Parichi; and in the southwest to the Pripyat marshes. 32 On June 22,1944 , the 9th Army reported no significant activity on its front. 33

\section{2nd Army}

The 2nd Army commanded by Colonel General Weiss contained 3 corps: XXIII Corps, XX Corps, and VIII Corps (see Figure 70). The 3 corps consisted of approximately 6 divisions and 2 brigades (see Figure 70). The 2nd Army also had the 2nd Hungarian Infantry Division, 1st Hungarian Cavalry Division, and the 4th Cavalry Brigade in reserve.

The 2nd Army reported two regimental strength attacks against the 3rd Cavalry Brigade. One attack was against Stolin and the other against Rytschew. Both attacks were repulsed.

$$
\text { JUNE 23, } 1944
$$

\section{3rd Panzer Army}

The situation northwest and southwest of Vitebsk developed into a crisis. The Soviets had broken through the German positions in the IX corps in the area south of Shumilino and had achieved 
freedom of movement in the direction of the Dvina River. ${ }^{34}$ The VI Corps southeast of Vitebsk had been penetrated in the area of the Pskov-Kiev road north of Boguschevsk to the west and south. 35 The encirclement of Vitebsk appeared imminent (see Figure 71).

IX Army Corps. The Soviets continued their pressure south of Obol. The Soviets in the area of Sirotino pushed units of the 252nd Infantry Division back to Ossinowka-Jurgewo. The Soviets renewed their major attack at $0400 \mathrm{hrs}$ after heavy artillery preparation. ${ }^{36}$ The commander of the IX Army Corps reported at $0900 \mathrm{hrs}$ that the 24th Infantry Division had assembled on the south bank of the Dvina at Obol to assist with the blocking of the Soviet advance. The IX Corps received the order at $1000 \mathrm{hrs}$ to hold a new line along the rail line including Shumilino. Major-General Heidkaemper briefed Field Marshal Busch about the necessity of the IX Corps to occupy the secondary defense position. Field Marshal Busch responded by ordering the "IX Army Corps to hold all its positions tenaciously that were currently occupied."37 Moreover, "the 24th Infantry Division had earlier closed the existing hole with one regiment and assault guns. ${ }^{38}$ Field Marshal Busch ordered an attack to restore the integrity of the front.

Colonel Praefke, Chief of Staff of the IX Corps reported that in the Corps Detachment $D$ sector the Soviets had forced their way over the rail line to Chotilowo and units of Corps Detachment $D$ under the personal leadership of the division commanders were attacking the Soviet penetration. ${ }^{39}$ Nevertheless, the Germans were thrown back across the rail line by a massive attack on a 
wide front (see Figure 71). The Soviets captured the rail station at Lowsha and attacked Spasskoje and Krizkije with armor and mounted infantry. Major General Heidkaempfer had the impression that the Soviets would turn their attack toward Vitebsk.

Therefore, it was especially important that Corps Detachment $D$ hold the Tiger Line. General of Artillery Wuthmann, Commander of IX Corps, reported at $1835 \mathrm{hrs}$ and $2020 \mathrm{hrs}$ that the blocking of the lake sector up to Moslino Lake could no longer be held. It was reported that only remnants of Corps Detachment $D$ were retreating. Wuthmann doubted that the troops of Corps Detachment D would be able to conduct further significant resistance. 40 Corps Detachment $D$ had only 20 light and 8 heavy field howitzers remaining and lacked ammunition.

Colonel-General Reinhardt criticized the fighting abilities of his troops. He stated:

the commanders are therefore responsible for seeing that the troops now fight as one demands. It is a scandal to speak of the loss of ability to resist after two days of battle. The Tiger Line is to be held at all costs. ${ }^{41}$

Meanwhile, further north the 24th Infantry Division lost Rowenz for the second time and the Soviets were advancing further to the southwest.

LIII Army Corps. Colonel Schmidt, Chief of Staff of the LIII Corps, recognized the need to withdraw to the secondary defense position in order to create more reserves and possibly disengage one complete division as early as $0500 \mathrm{hrs}$. There were no infantry 
attacks during the day but the situation on the flanks of the LIII Corps was appearing desperate as the encirclement of Vitebsk was beginning to appear imminent (see Figure 72). General of Infantry Gollwitzer, Commander of LIII Corps, requested to withdraw to the secondary defensive positions at 1700 hrs. Field Marshal Busch agreed but he had to get Hitler's approval. ${ }^{42}$ Meanwhile, Field Marshal Busch issued the following order:

The position was to be held under all circumstances, therefore, regardless of the consequences everything possible was to be carried out so far as the situation permitted. 43

General Gollwitzer in a conversation with Colonel General Reinhardt expressed the concern that there must be a withdrawal to the rear positions of Vitebsk to create reserves since the corps rear was completely open (see Figure 73). ${ }^{44}$ Meanwhile, alert units in Vitebsk reported Soviets west of the 246th Infantry Division advancing toward the Dvina river. Hitler approved the withdrawal of the LIII Corps to the secondary defense position and this order was received at $1850 \mathrm{hrs.} 45$ During the late afternoon the encirclement of Vitebsk appeared even more distinct. General Gollwitzer received an order at $1945 \mathrm{hrs}$ to assemble the 4 th Luftwaffe Field Division in Ssossnowka for an attack in the direction of VI Army Corps. A further advance of Soviet armored forces to the west and northwest must be prevented. General Gollwitzer reported at $2200 \mathrm{hrs}$ that weak Soviet forces had crossed the Dvina River at Komli and had been destroyed. The 
Corps reportedly had no further forces to secure the area further to the west. Furthermore, General Gollwitzer was of the opinion that Corps Detachment $D$ had not occupied the Tiger Line which granted the Soviets appearing on the west bank of the Dvina River complete freedom of movement. 46 The highway from Vitebsk to the west was already under antitank artillery fire. Four Soviet tank brigades were reported south of Vitebsk.

VI Army Corp. Strong Soviet attacks were reported throughout the night. Heavy artillery and mortar fire preparation was laid down along the entire front between the left wing of the 256th Infantry Division and Makarowa in the 197th Infantry

Division's sector. The hole in the line at Starobobylje remained open. The Soviets also achieved a breakthrough in regimental strength between Schnitki and Lepeschino to the Pskov-Kiev (PK) road at Juschkowo. The Soviets were firing on Bogushevsk by 0830 hrs. During the morning in the 256th Infantry Division's sector the Soviets took the villages Ordesh, Ossipowa and Juschkowo. Then their attack shifted to Sselenki and Stryganzy. The Soviets also broke through the 299th Infantry Division and were already on the rail line in Samostotschje. The right wing of the 197th Infantry Division collapsed under a Soviet attack preceded by an artillery barrage. The Soviets pushed over the Lutschessa River and the rail line to the west (see Figure 74). In the evening Ustche and Schilki were lost so that the 197th Infantry Division was separated from the VI Army Corps (see Figure 74). Therefore, the LIII Corps took command of the division. 
Colonel-General Reinhardt briefed Field Marshal Busch at 2305 hrs on the situation of the 3rd Panzer Army. He especially stressed the hole in the front on the boundary between the LIII Corps and the IX Corps. ${ }^{47}$ Field Marshal Busch demanded the closing of the hole. Reinhardt referred to the anticipated new danger when the Soviets continued their attack on June 24th and the 5th Guards Rifle Corps entered the battle from the area of Sirotino. 48 Field Marshal Busch ignored the reality of the impending encirclement of Vitebsk thereby endangering the entire LIII Army Corps.

\section{4th Army}

The Soviets began their attack against the 4th Army after the heaviest artillery barrage that had ever been experienced in the entire war. ${ }^{49}$ The massive Soviet thrusts against the center of the 4th Army were conducted with strong armored forces and close support aircraft. The Soviets had to use massive force on this front because the 4th Army had the strongest defensive forces deployed (see Table XXXVI).

XXVII Army Corps. The Soviets broke through the middle of the 78th Assault Division's sector north of the highway and pushed through to Orechi.50 The area northeast of Ramaldowo was also penetrated.

XXXIX Panzer Corps. The Soviets advanced along both sides of the road Rjassna-Mogilev up to $6 \mathrm{~km}$ in depth into the 337th Infantry Division's sector. 51 The Soviets had attacked this sector 
with 5 divisions. In the afternoon, the Soviets broke through northwest of Radomlja.

Meanwhile, General Tippelskirch repeated in vain his request to withdraw behind the Dnieper river. ${ }^{52}$ The Army Group responded to his request by releasing a reinforced regimental group from the Panzer Grenadier Division "Feldherrnhalle" to reinforce the front east of Mogilev. The remainder of the understrength division was only permitted by Army Group Headquarters to be deployed in the Dnieper covering position. General Tippelskirch was not satisfied with these measures and requested at $2050 \mathrm{hrs}$ either unrestricted use of the entire Panzer Grenadier Division "Feldherrnhalle" or authorization to withdraw into the Dnieper covering position and the Hessen line.53 This would shorten the front considerably which had been lengthened still more since the beginning of the battles that lead to the Soviet breakthroughs in the XXXIX Panzer Corps and the XXVII Army Corps sectors. 54

Field Marshal Busch did not grant approval for the withdrawal, but assigned the complete Panzer Grenadier Division "Feldherrnhalle" to the 4th Army with the restriction that it could only be used in the Dnieper covering position.55 Busch also ordered the 14th Infantry Division out of the 4th Army sector to the north into the 3rd Panzer Army sector to be employed in the Tiger line on both sides Bogushevsk. This deprived the 4th Army of a potential reserve division. The 4th Army had only the 286th Security Division and the Heavy Tank Battalion 501 with 29 Tiger tanks available for reserves. ${ }^{56}$ Field Marshal Busch demanded that the 
4th Army "stand fast" holding an overextended front with inadequate reserves against a numerically superior enemy. The use of flexible defense was denied.

\section{9th Army}

The Soviets opened their offensive against the 9th Army in the XXXXI Panzer Corps and the XXXV Army Corps sectors. In the XXXXI Panzer Corps sector the Soviets attacked across the entire front in battalion to regimental strength and were generally repulsed. In the XXXV Army Corps sector the left flank of the 296th Infantry Division was attacked in battalion strength and the Soviets were repulsed. The main weight of the Soviet offensive would fall on the 9th Army sector beginning on June 24, 1944.

$$
\text { JUNE 24, } 1944
$$

\section{3rd Panzer Army}

The Soviet offensive achieved several critical objectives. In the south, the Soviets widened their breakthrough over the rail line to Bogushevsk and to the south. The Soviets continued their advance with strong armored and motorized formations to the west and northwest through the hole between the VI and LIII Army Corps. Units of the 3rd Guards Corps reached the area of Ostrovno and blocked the last connection of the LIII Corps to the west. ${ }^{57}$ Soviet forces from the north also reached the Dvina river. Therefore, Vitebsk was completely encircled (see Figures $75 \& 76$ ). The LIII 
Corps received the order to attack to the southwest to restore the connection to the Tiger line and hold it open.

IX Army Corps. The Soviets broke through on both sides of the Leskowitschi lakes with armor and mounted infantry pushing in the direction of Uwoloki-Pissarewo. The IX Corps was ordered to occupy the line along the Dvina river between Komli and Ulla. After the Tiger line was penetrated on a wide front the IX Corps was to fight its way back to the Dvina river and prevent the Soviets from crossing between Budilow and Ulla. The defensive position north of Beshenkovichi was to be held by Corps Detachment $D$. Between Ulla and the right flank of the 24th Infantry Division Soviet units were advancing west. The Soviets broke into the 252nd Infantry Division's defensive line and took Latkowo and were continuing to advance with numerically superior infantry and armor forces. The 290th Infantry Division was transferred from Army Group North and placed under command of the IX Corps along with the 24th Infantry Division. ${ }^{58}$ The 290th Infantry Division and a motorized artillery battalion were in transport to close the hole between the Dvina river at Kordan and the right wing of the 24th Infantry Division. All available forces which included retreating divisional units, construction and security units of the IX Corps were put into the Dvina position from Budinowo to the northwest of Ulla. The bridgehead at Ulla had to be abandoned and German forces retreated across the Dvina river blowing up the bridges.59 Southwest of Obol the Soviets took Leonowo. Field Marshal Busch arranged the 
reinforcement of this front by transferring the 212th Infantry Division from Army Group North.60

VI Army Corps. General Krebs, Chief of Staff Army Group Center, reported at $1105 \mathrm{hrs}$ the reinforcement of VI Corps by the 14th Infantry Division minus one regiment left with the 4th Army. The Soviet breakthrough area on the open left wing of the corps was extremely threatening (see Figure 77). Two Soviet regiments with approximately 40 tanks were observed advancing to the south on the Bogushevsk-Senno road. Colonel Mantey, Chief of Staff VI Corps, reported that the Soviet main effort south of Vitebsk was on both sides of Bogushevsk. The corps reported that the 256th Infantry Division could no longer hold its position. The Army Group ordered the withdrawal of the VI Corps into the Tiger line at 1245 hrs (see Figure 78). 61 The Tiger line was to be occupied between the army border and Bogushevsk which was completed successfully. The Soviets around $1200 \mathrm{hrs}$ launched continuous strong attacks supported by at least 120 tanks against both sides of Bogushevsk in the Tiger line which had been occupied by the 14th Infantry Division. Nevertheless, Bogushevsk was captured by the Soviets. The hole between the VI Corps and the LIII Corps permitted the Soviets to advance to the west and northwest (see Figure 77).

LIII Army Corps. The LIII Corps was in the greatest danger occupying the Vitebsk salient. The Soviets were advancing through the hole to the north to Sarudniza. The Commander of the 3rd Panzer Army, Colonel General Reinhardt, ordered the 4th Luftwaffe Field Division to assemble at Ostrovno and from there to advance 
to the southeast at $1040 \mathrm{hrs}$. The Soviets advancing to the northwest through the hole to the LIII Corps were already on the outskirts of Ostrovno and Lichoschina. The first arriving battalions of the 4th Luftwaffe Field Division were ordered to stop the Soviet advance. Thus, A crisis in the 3rd Panzer Army had developed because of the large gaping hole in the center between the VI Corps and LIII Corps which could not be closed because there were no available forces. 62

Chief of Staff of the Army, Colonel General Zeitzler called Colonel General Reinhardt at 1525 hrs and informed him that the Fuehrer was very much against an evacuation of Vitebsk because Hitler believed "this would start the ball rolling."63 Reinhardt advised Zeitzler that the decision to evacuate Vitebsk today was imperative so that the forces could be brought out to hold other positions. Therefore, it was urgently required that the troops come out now before the encirclement so that they retained their operational abilities. ${ }^{64}$ Reinhardt feared that this would be recognized "too late."65 Colonel General Zeitzler consulted with the Fuehrer and informed Reinhardt at 1535 hrs that the Fuehrer decided Vitebsk was to be held as a "fortress, and everything must be attempted so the formations can hold it. ${ }^{6} 6$ The LIII Corps reported the loss of Shigaly and Soviet advances from Gorki and Tolstjuki in unknown strength to the north.

Colonel General Reinhardt informed Lt. General Krebs it was no longer possible to keep Vitebsk open since the Soviets already 
have occupied the perimeter road and the road from Vitebsk to Lepel was under Soviet fire.67 Colonel General Reinhardt stated:

The new situation makes the ordered solution impossible. Something must happen immediately. There is no longer another solution like the previous proposal. 68

Reinhardt reasoned that the forces in Vitebsk could be used to close the hole between the VI and IX Army Corps. Then a new defensive front could be constructed. However, if the order to evacuate Vitebsk was not given the hole between VI and IX Corps would grow even larger. The encirclement of the divisions in Vitebsk was almost completed and the 3rd Panzer Army's commander's plan for the new defensive front based on the reality of the situation was ignored by Hitler.

Meanwhile, Lt. General Krebs and Col. General Zeitzler had conferred and spoke to Col. General Reinhardt at 1615 hrs. Lt. General Krebs informed Reinhardt that Field Marshal Busch believed that one division was sufficient to hold Vitebsk. Therefore, the other divisions were free to breakout to the rear to restore communication to the rest of the 3rd Panzer Army.69 Lt. General Krebs informed Reinhardt the 5th Panzer Division was on its way from Orsha. Reinhardt requested that the IV Flieger Division provide some air support over Vitebsk since the Soviets had air superiority. 70 General Reuss reported that his fighters were without their forward air strip at Ulla and the Stukas had been concentrated on the 4th Army sector. Later in the afternoon 
fighters appeared in the area of Vitebsk. Col. General Reinhardt informed Field Marshal Busch at 1820 hrs that the Soviets had reached the south edge of Ostrovno and occupied Lichoschina. The 4th and 6th Luftwaffe Field Divisions were to secure the road to the west of Vitebsk and hold it open. The order was now: "about face, fight back to the Tiger line."71

Field Marshal Busch informed the 3rd Panzer Army of his decision to hold Vitebsk:

His request for the Army to completely abandon Vitebsk had been denied. There were special reasons which made it essential to hold Vitebsk. Therefore, one division will remain in Vitebsk which is the 206th Infantry Division. Lt. General Hitter is appointed the new battle commander. The LIII Corps Commander is to ensure that the order to hold Vitebsk is followed. The breakout of the other Vitebsk divisions shall be conducted under the leadership of the corps commander. ${ }^{72}$

General Gollwitzer proposed that the commander of the 206th Infantry Division be appointed as Commandant of "Fortress Vitebsk." Lt. General Hitter was appointed by Field Marshal Busch in accordance with Fuehrer Order Nr. 11 Commander of "Fortress Vitebsk." (see Appendix C)..$^{73}$

The LIII Army Corps in order to breakout of the encirclement would have to traverse a $35-40 \mathrm{~km}$ hole that existed between the VI and IX Army Corps. ${ }^{74}$ The Soviets continued to press through this hole to the area south of the Dvina River. The line of lakes at Chodzy was now under Soviet control. Thus, the LIII Army Corps was becoming progressively separated from the remainder of the 
3rd Panzer Army as a result of unrealistic command directives issued by the Army High Command which was subject to Hitler's demands.

\section{4th Army}

The Soviets continued to make headway in both breakthrough areas by use of heavy attacks supported by massed tanks. Each breakthrough position contained a Soviet Tank Corps. The Soviet Breakthrough position in the XXXIX Panzer Corps sector contained 700 trucks loaded with Soviet infantry and numerous tanks. ${ }^{75}$ The German front had been stretched to a thin security line. The 337th Infantry Division had already lost more than $3 / 4$ of their artillery.

The Chief of Staff of the 4th Army, Colonel Dethleffsen requested approval from Army Group Center to withdraw the 4th Army Front back to the Dnieper covering position at $1100 \mathrm{hrs}$. However, the Army Group at $1250 \mathrm{hrs}$ only approved the withdrawal of the left wing of the 4th Army on an $8 \mathrm{~km}$ stretch into the Tiger line between Orechi and Dewinskoje Lake. General von Tippelskirch conferred at 1945 hrs with Field Marshal Busch about the withdrawal to the Dnieper covering position, but the withdrawal was denied. Even a $6 \mathrm{~km}$ withdrawal of the 12th Infantry Division's left flank was not permitted by Field Marshal Busch. Field Marshal Busch reasoned:

the prepared positions may not be abandoned because otherwise the enemy would receive encouragement. 76 
In summary, the situation in the breakthrough areas was tense. The Soviets in the breakthrough sector of the 78th Assault Division continued to advance with armored forces to the south (see Figure 79). The 78th Assault Division was ordered to withdraw to the Hessen line west of Teolin from the Dnieper and connect into line Makarowo-Bridgehead-Orsha-Orechi Lake-Tiger line. ${ }^{77}$ In the XXXIX Panzer Corps sector the 12th Infantry Division could no longer hold its position and it withdrew behind the river Basya. The 337th Infantry Division consisted only of severely battered remnants and the Soviets had already crossed the river Basya in this sector. The critical problem was that a critical hole emerged between the 337th and 12th Infantry Divisions (see Figure 80). ${ }^{78}$ There were no available forces to close the hole.

General von Tippelskirch attributed the surprising success of the Soviets in the first two days of combat to several factors:

1. The Soviet artillery had more ammunition and a longer barrage than in previous major offensives.

2. The fire control was more flexible and German artillery was targeted more than previously.

3. The Soviet air superiority was especially noticeable.

4. The Soviet armor followed rapidly behind the infantry breakthroughs.

5. The breakthrough success was rapidly exploited and both tanks and infantry immediately advanced into the depth of the defense toward distant objectives. 79 
Major General Schuermann, Commander of the 25th Panzer Grenadier Division attributed Soviet success to the following factors:

1. The Soviets employed an enormous number of tactical aircraft and there was almost a complete absence of German aircraft.

2. The Germans lacked operational reserves.

3. The Front was totally overextended. 80

The 4th Army lacked adequate reserves to counter the Soviet breakthroughs. The Panzer Grenadier Division "Feldherrnhalle" was restricted to use in the Dnieper covering position and the 14th Infantry Division was dispatched to the 3rd Panzer Army.

Tippelskirch argued that if the 4th Army had been given a free hand the situation could have been brought under control. The 4th Army on June 24th still had 10 divisions and 7 were completely combat ready: $57,267,31,12,110,260$ Infantry Divisions, and the 18 Panzer Grenadier Division.81 Even the 25th Panzer Grenadier Division was intact with only its left regiment locked in a major engagement. The division still had at its disposal a considerable number of anti-tank weapons.

The fate of the 4th Army hung in the balance as early as the evening of the second day of the Soviet offensive. A continuous front no longer existed on the 4th Army sector. Field Marshal Busch at midnight informed the 4th Army that the Soviets had broken through at Bogushevsk with 120 tanks. ${ }^{82}$ General von 
Tippelskirch ordered General Voelckers of the XXVII Army Corps to concentrate all assault guns and self-propelled artillery on the left wing. In addition, two battalions of infantry were sent from Staiki in the rear to the left wing of the XXVII Corps.

\section{9th Army}

The Soviets attacked in the XXXV Army Corps sector with 5-7 Rifle Divisions and two tank formations. They achieved a wide breakthrough north of Rogachev along the inner flanks of the 296th and 134th Infantry Divisions. The Soviets broke through the center of the 134th Infantry Division with strong armored forces on a 3 $\mathrm{km}$ wide front which extended into the wooded terrain southwest of Oserani (see Figure 81). The greatest Soviet success was achieved south of the Berezina River in the XXXXI Panzer Corps sector. The attack consisted of 15 Soviet Rifle Divisions and 3 tank formations attacking in the direction of Osaritschi and Dubrowa. The 129th Infantry Division was pushed back to Tremlja after strong artillery preparation and the 35th Infantry Division to a line extending from Tremlja to $10 \mathrm{~km}$ northeast of Wolossowitschi to $6 \mathrm{~km}$ northwest of Tschernin. A gap developed between the left flank of the 35th Infantry Division and Tschernin and the right flank of the 36th Infantry Division (see Figure 81).83 The 9th Army acquired the use of the OKH reserves: 20th Panzer Division and 707th Infantry Division.84 The 20th Panzer Division was ordered to deploy to the south in the XXXXI Panzer Corps sector after having first been sent north to support the XXXV Army Corps. 
The fear was that a breakthrough in the south toward Bobruisk would cut the main supply route to the forces deployed east of the Berezina River. ${ }^{85}$

JUNE 25, 1944

\section{3rd Panzer Army}

The situation of the 3rd Panzer Army grew worse by the hour. The Soviets widened the hole between the VI Army Corps and the Dvina river by $50 \mathrm{~km}$ and new Soviet forces were advancing into this hole from the north toward Beschenkowitschi.86 The closing of this gap was not possible with the available existing forces. The LIII Army Corps was surrounded in Vitebsk and the 290th and 24th Infantry Divisions along with the entire VI Corps were removed from the 3rd Panzer Army (see Figure 92). ${ }^{87}$

IX Army Corps. The Soviets crossed the Dvina River on both sides of Beschenkowitschi. Soviet tanks with mounted infantry also appeared north of Beschenkowitschi. Chief of Staff, Major General Heidkaempfer ordered the IX Corps at $0925 \mathrm{hrs}$ to hold Beschenkowitschi at all costs. Further instructions were given to Security Regiment 45, 201st Security Division, 252nd Infantry Division, and the Army Weapons School to build a new defense line between the Lukomskoje Lake and Poluoserje Lake. The 290th and 24th Infantry Divisions were removed from the IX Corps control and placed under the tactical control of Army Group North's I Army Corps. ${ }^{88}$ The 212 th Infantry Division was to advance immediately 
to the area of Parafjanow. The Commander of the 262nd Infantry Divisional group in Beschenkowitschi reported to the IX Corps at 1120 hrs that the Soviets had reached the road UllaBeschenkowitschi and were in the town Pjatigosk. The IX Corps next report at $1340 \mathrm{hrs}$ reported the Soviets reaching the Sswetschanka river west of Beschenkowitschi. The Corps requested to withdraw to the line of lakes to the south. Col. General Reinhardt informed Field Marshal Busch that the Dvina sector will be overrun and the Soviets could make it to the line of lakes to the south before our own troops. The Field Marshal answered, "the withdrawal was completely ruled out. The Dvina position must be held."89 Major General Heidkaempfer reported to Lt. General Krebs at $1425 \mathrm{hrs}$ that the situation could not last much longer or the Soviets would reach the Poluoserje Lake and then the IX Corps would have no possibility of reinforcing its right wing. Beschenkowitischi was surrounded (see Figure 82). Soviet armor was advancing to the southwest from Ssenno threatening the Army's rear (see Figure 82). Col. General Reinhardt informed Lt. General Krebs that the Soviets displayed the tendency to advance in the direction of Lepel. If the troops were to occupy the favorable ground around the lakes then the decision must be made to abandon the Dvina position of our own free will and in good time otherwise it will again be "too late."90 But Field Marshal Busch in two further messages at $1515 \mathrm{hrs}$ and $1540 \mathrm{hrs}$ gave the order that the Dvina position was not to be evacuated because the LIII Army Corps had to fight its way out.91 The Soviets were reported to have occupied 
Sswetscha at $1700 \mathrm{hrs}$. General Wuthmann reported at $1825 \mathrm{hrs}$ that the battle in Beschenkowitschi was still continuing. The garrison of Beschenkowitschi was finally ordered to fight their way back to the main battle line during the night.

VI Army Corps. The 14th Infantry Division was reported to have been overrun by Soviet armor at $0900 \mathrm{hrs}$. A penetration of the Tiger line at Saoserje in the 95th Infantry Division's sector succeeded. The withdrawal of the 95th Infantry Division was permitted. It was withdrawn behind the Oboljanka River (see Figure 82). Maj. General Heidkaempfer was informed in a conference at $1000 \mathrm{hrs}$ with Lt. General Krebs of the necessity of the VI Army Corps to be placed under the command of the 4th Army because of the circumstances and the withdrawal of the Corps towards the 4th Army sector. Lt. General Krebs confirmed this discussion with an order at 1110 hrs placing the VI Corps under the command of the 4th Army and extended the 4th Army's area of responsibility to the area of Ssenno (see Figure 82). .92

LIII Army Corps. The LIII Corps was cut off from the rest of the 3rd Panzer Army (see Figure 83). Lt. General Hitter had been the Commandant of Fortress Vitebsk since $0400 \mathrm{hrs}$ and General Gollwitzer of the LIII Corps was preparing the Corps for a breakout from Vitebsk. Vitebsk was under attack from units of the Soviet 43rd and 39th Armies. ${ }^{93}$ The LIII Corps reported at $1315 \mathrm{hrs}$ that the encirclement of Vitebsk was now complete. ${ }^{94}$ The 4 th Luftwaffe Field Division had virtually ceased to exist as a divisional unit and the 246th Infantry Division along with the 6th 
Luftwaffe Field Division were engaged in bitter battles. ${ }^{95}$ Several penetrations into the actual city of Vitebsk had occurred. The Corps urgently requested fighter air cover. General Gollwitzer in Vitebsk reported at 1900 hrs that he would concentrate his forces for a breakout to the southwest beginning at $0500 \mathrm{hrs}$ on June 26th.96 He requested air cover over the area southwest of Vitebsk. Col. General Reinhardt advised General Gollwitzer that on the basis of Fuehrerbefebl Nr. 11 (see Appendix C) the 206th Infantry Division with Lt. General Hitter as commander were to hold Fortress Vitebsk. 97

Field Marshal Busch had the impression that General Gollwitzer must have received a new withdrawal order with details of the breakout. Busch ordered at $1845 \mathrm{hrs}$ that a General Staff Officer from 3rd Panzer Army be flown or dropped by parachute into Vitebsk to brief General Gollwitzer on the overall situation. Field Marshal Busch called 3rd Panzer Army again at $2000 \mathrm{hrs}$ and insisted once again that a General Staff Officer be sent to Vitebsk. Col. General Reinhardt maintained that this was not practical and apparently set this request aside.98 But Chief of Staff, 3rd Panzer Army, Maj. General Heidkaempfer declared that Col. General Reinhardt informed Field Marshal Busch of his decision in the following manner:

Field Marshal, please inform the Fuehrer that only one officer in the 3rd Panzer Army can be considered for this jump, and that's the Army Commander. I am ready to execute his order. 99 
There was no further discussion of this order after Reinhardt's statement. Lt. General Krebs informed Maj. General Heidkaempfer that Hitler wanted the 206th Infantry Division to hold Vitebsk for 6-7 more days. 100

Lt. General Hitter reported at 2006 hrs a breakthrough into the northeast section of Vitebsk and a struggle in the northwest section which was very serious. Bitter street battles in Vitebsk and deep penetrations along the Pskov-Kiev (PK) road were reported. The 4th Luftwaffe Field Division Headquarters was surrounded in Ostrowno while the rest of the division ceased to exist (see Figure 83). 101

Meanwhile, Major Balve was briefing Colonel Graf von Kielmansegg about the 3rd Panzer Army situation and the lack of antitank weapons. During the briefing Colonel Kielmansegg expressed the revisionist view from $\mathrm{OKH}$ :

Over the rapid falling back no reproaches from anyone. Everybody was taken by surprise by the enemy's strength. Presently, there are still no operational reserve formations that have appeared from the southern front. The view at $\mathrm{OKH}$ is that things would not have gone much better if the abandonment of Vitebsk had been ordered in good time. 102 Major Balve, however, spoke out vigorously against this false view.

The 3rd Panzer Army was in serious trouble since two large holes had been ripped through their front by Soviet armor and mounted infantry. A central problem was not only lack of reserves but an extreme shortage of antitank weapons. 3rd Panzer Army notified Army Group Center that with assignment of the VI Army 
Corps to the 4th Army and divisions north of the Dvina to the 16th Army that the majority of antitank weapons had been lost. 103 The VI Corps had Panzer Jaeger Battalion 519 while Sturmgeschuetz (assault gun) Brigades 281, 245 and 909 were all located north of the Ulla. LIII Army Corps had only 3 assault gun battalions and this left 3rd Panzer Army with only one Sturmgeschuetz (assault gun) Brigade to meet the on rushing Soviet Tank Brigades. 3rd Panzer Army requested the return of Assault Gun Brigade 909 and other Nashorn and assault gun battalions.

\section{4th Army}

VI Army Corps. The newly assigned VI Corps reported at $0850 \mathrm{hrs}$ that a Soviet Column was advancing through the wide hole between its divisions and had reached the area north of Ssenno. The Soviets were also reported at $1030 \mathrm{hrs}$ as having advanced 10 $\mathrm{km}$ southwest of Boguschewskoje. The VI Corps had withdrawn to the line Staiki-Papino-Schinkow (12 km southeast of Ssenno). Army Group Center officially informed VI Corps with the 256th, 299th, 14th and 95th Infantry Divisions that it was now under the command of 4th Army. 104 The Army Group informed the 4th Army and the VI Corps that the 5th Panzer Division was coming up from the rear by train to reinforce this sector.

XXVII Army Corps. Soviet attacks continued throughout the evening and night. The 78th Assault Division north of the Dnieper River organized a new defense line: Teolin-Makarowo-WydrizaKupelka-Orechi Lake-Tiger line. Orechi was lost and Soviet armor 
was pouring through Boguschewskoje advancing to the northeast towards Smoljany. 105 Soviet armor was now in Ssenno $30 \mathrm{~km}$ further to the west.106 The XXVII Army Corps reported that the Soviets had broken through south of the Orechi Lakes and Soviet armor was now in Ussy. General Tippelskirch ordered the right wing of the XXVII Army Corps to prepare to withdraw to the Hessen line (see Figure 84).

XXXIX Panzer Corps. The Soviets attacking from the southeast took Ssuchari and the 337th Infantry Division was forced into retreat to the Resta River where it would then prepare for withdrawal to the Dnieper covering position. The XXXIX Panzer Corps was ordered at $\mathbf{1 1 0 0} \mathrm{hrs}$ to prepare for a withdrawal to the Dnieper covering position. The 337th Infantry Division was pushed back and entered Krugloje. Field Marshal Busch gave his approval to withdraw the 31st and 12th Infantry Divisions at night to the Dnieper covering position. However, the 260th Infantry Division and the 25th Panzer Grenadier Division of the XXVII Corps along with the 110th Infantry Division were to remain in their present positions. 107 The Panzer Grenadier Division "Feldherrnhalle" in the Dnieper covering position was broken through at Ssuchari. 90 Soviet tanks followed by trucks were advancing toward Mogilev (see Figure 85). 108

The situation had become critical and General Tippelskirch could no longer wait for approval from Field Marshal Busch and then Hitler. Tippelskirch ordered the withdrawal of the entire front between Ssutoki (on the left flank of the 18th Panzer 
Grenadier Division) and the Dnieper northeast of Orsha back into the Dnieper covering position and Orsha Bridehead (see Figure 86). ${ }^{109}$ Field Marshal Busch when briefed on Tippelskirch's actions was outraged. He told Tippelskirch that this was "an act in contravention of orders."110 Furthermore, he had defied an order from Hitler that only the 31st and 12th Infantry Divisions were allowed to withdraw to the Dnieper covering position. ${ }^{111}$ Field Marshal Busch ordered General Tippelskirch to have the divisions reoccupy the former battle line.

General von Tippelskirch then issued the following order to the XXVII and XXXIX Corps:

In all parts of the front not under attack, troops are to hold firm until they are attacked by a superior enemy force and then pushed back. The only troops to be withdrawn from the front are those needed to close the gap between the 78th Assault Division and the 25th Panzer Grenadier Division and those needed to cover the Dnieper River crossings which are threatened. 112 However, Tippelskirch had not ordered the divisions to return to their former positions as Field Marshal Busch had ordered. This dispute became moot when Hitler at $2310 \mathrm{hrs}$ approved the withdrawal of the other divisions. ${ }^{113}$

\section{9th Army}

XXXV Army Corps. The Soviets attacked with 12 Rifle Divisions and the 9th Tank Corps out of the area north of Rogatschew in an attempt to sever the highway (see Figure 87). 114 The Soviets would in further attacks against the flank of the Drut 
River Bridgeheads attempt to split up the front. However, the $\mathrm{XXXV}$ Corps achieved some local defensive success knocking out 120 Soviet tanks.115 But the Soviets had severed the connection to the 4th Army. Despite some local successes, the $15 \mathrm{~km}$ gap on the left of the corps could not be closed. In the center the Soviets had crossed the Drut River and were $5 \mathrm{~km}$ west of Ozarichi and $5 \mathrm{~km}$ west-northwest of Rogatschew (see Figure 87). The situation became worse by midnight. The left flank was ripped open (see Figure 87). Units of the 707th and 134th Infantry Divisions were fighting southwest of Buda. Both the 134th and 196th Infantry Divisions had been penetrated between Ozarichi and Rogatschew. The Soviets were now $10 \mathrm{~km}$ northwest of Ozarichi and had crossed the Rogatschew-Bobruisk road in the southwest (see Figure 87). The XXXV Corps had exhausted its reserves to defend its left flank by withdrawing battalions from the 6th, 383rd, and 45th Infantry Divisions in the center.

XXXXI Panzer Corps. The Soviets had overwhelmed the 35th Infantry Division's defense (see Figure 85). ${ }^{116}$ The 20th Panzer Division arrived just in time to destroy the Soviet crossing attempt on the Rudnya River east of Slobodka. The 20th Panzer Division, however, could not continue its attack because the crossing site was lost. The 36th Infantry Division and the 20th Panzer Division achieved a rendezvous southwest of Parichi. The left flank of the 36th Infantry Division was penetrated and had to fight its way back to the Berezina River $3 \mathrm{~km}$ east of Parichi (see Figure 88). The 129th Infantry Division was also penetrated in 5 
places. The 35th Infantry Division was fighting its way back to the area north and northwest of Shkava. It was reported that 200 trucks loaded with Soviet infantry had crossed the railway through Zelenkovichi to the west.

General Jordan anticipated that the 9th Army would soon be facing an encirclement battle. He requested that Field Marshal Busch permit him to withdraw the XXXV Corps southern front thereby releasing the 383rd Infantry Division. However, Field Marshal Busch responded:

The Army without regard to the success of the enemy breakthroughs has to remain in their present positions where that is possible.117

The 9th Army realizing its precarious situation reached the same solution repeatedly that the situation could only be restored if the 9th Army forces were granted immediate freedom of action by the withdrawal of the entire front to the Berezina River and the Bobruisk bridgehead (see Figure 89). But the answer was that the defensive mission of the Army had not changed and that "not one foot of ground was to be voluntarily abandoned."118

If Army Group Center was to have saved itself then decisive action would have been required on June 25,1944 to restore a badly ruptured front by immediately withdrawing all divisions and the entire front line further to the west to form a new defensive line on the Berezina River. But instead Hitler insisted on "standing fast" and this permitted the Soviets to encircle entire army corps as the offensive progressed. There was a vacuum of leadership at 
Army Group Center. Field Marshal Busch failed to listen to his army commanders and instead became a rubberstamp for Hitler's orders. He failed to take decisive actions of his own to save his army group. Therefore, armies which had demonstrated superb leadership in the past in fending off the Red Army now were deprived of the freedom of action necessary to save themselves from annihilation. The fate of the LIII Army Corps, 4th Army, and 9th Army was sealed more by Hitler's orders than Soviet offensive actions.

General Jordan's expression of bitterness over the OKH and Army Group failures was expressed in the Kriegstagebuch on June 25, 1944:

Headquarters 9th Army is fully aware of the disastrous consequences of all these orders. It can accept them only inasmuch as, after representing his opposing view upwards in a responsible manner, a commander in the field is obliged to carry out the orders of his superior, even if these go against his own convictions. It is a bitter pill to swallow, though, when one feels that, behind these Army Group instructions which so utterly ignore one's own pressing suggestions, and behind the answers given by the Field Marshal and his Chief of Staff, one can see no sign of a commander showing any purposeful will to do his utmost, but just the execution of orders whose basis has long since been overtaken by events. 119 
JUNE 26, 1944

\section{3rd Panzer Army}

The situation of the 3rd Panzer Army became more critical with only weak units occupying the front which was threatened by strong Soviet forces. The area of Lepel was the only front which could be reinforced. LIII Army Corps attempted a breakout to the southwest. The main effort of the Soviets was centered at Botscheikowo.

IX Army Corps. In the early morning the Soviets attacked the Dvina line on both sides and south of Ulla and achieved several breakthroughs over a wide front. The 252nd Infantry Division fought its way back to the lake bottleneck of Poluoserje Lake Ussweja Lake. During the night encircled units of Corps

Detachment $D$ in Beschenkowitschi broke out to the southwest (see Figure 90). ${ }^{120}$ The Soviet main effort was shifted from Corps Detachment $D$ to the 252nd Infantry Division according to General Wuthmann of the IX Corps at $0900 \mathrm{hrs}$. Corps Detachment D took over the southern tip of Paluoserje Lake. It was unclear what units of the 252nd Infantry Division had been able to fight their way back. The 16th Army of Army Group North assigned Panzer Jaeger Battalion 519 consisting of Nashorns (self-propelled $88 \mathrm{~mm}$ guns) and Sturmgeschuetz Brigade 909 consisting of assault guns to reinforce the IX Corps. The arrival of the 212th Infantry Division was delayed a few hours because of several rail demolitions north of Parafjanow. 
The IX Corps reported at 1230 hrs that the Soviets had secured a bridgehead at Botscheikowo and the poorly equipped security troops could not withstand an attack. General Wuthmann reported a Soviet concentration of 60-70 tanks at Botscheikowo. General Heidkaempfer emphasized the need to concentrate as much artillery as possible against this armored concentration especially assault guns and Hummels (self-propelled $150 \mathrm{~mm}$ guns). General Wuthmann pulled back the remnants of the 252nd Infantry Division south of Poluoserje Lake to meet this Soviet concentration. The artillery of the 252nd Infantry Division was assigned to cover the Division sector and Botscheikowo. Col. General Reinhardt urgently requested air strikes against the Soviet armor concentration facing Botscheikowo. General Wuthmann of IX Corps reported at 1900 hrs that Soviet armor had broken through at Botscheikowo. 121 The security troops were in retreat. Even with the arrival of assault guns from Sturmgeschuetz Brigade 277, a counterattack could not be conducted since the troops were incapable of further combat at this time. The right wing of the IX Corps was withdrawn to the lake line at the beginning of darkness: Soroschina LakeNessino Lake-Ostrowno Lake-Woroschky Lakes-southern tip of Poluoserje Lake (see Figure 90).

LIII Army Corps. The morning of June 26th looked bleak for the surrounded LIII Corps. General Gollwitzer thanked Col. General Reinhardt for his wishes of good luck and reported that he would fight to the last. In the early morning a report from the corps indicated that the 206th Infantry Division was outside of the 
defensive ring with significant units as a result of the development of the situation, and regrouping was no longer possible because of heavy fighting. ${ }^{122}$ There were only 4 battalions available to defend the "firm position" in Vitebsk so the conditions for carrying out the Fuehrer's order no longer existed. ${ }^{123}$ The entire corps must now either remain in Vitebsk or breakout including the 206th Infantry Division. ${ }^{124}$ The situation and the orders had made this last decision necessary.

Presently at $0700 \mathrm{hrs}$ bitter battles were raging in southern and western Vitebsk. The LIII Corps had begun the breakout at $0500 \mathrm{hrs}$. Lt. General Krebs reported at $1130 \mathrm{hrs}$ that intervention to assist the LIII Army Corps was no longer possible. The battle for Vitebsk was to continue. Field Marshal Busch in a discussion with Col. General Reinhardt demanded that the following unequivocal radio order be sent to General Gollwitzer and General Hitter in Vitebsk:

Vitebsk with the ordered units is to be held. No freedom of decision! You are bound by the Fuehrer's order. ${ }^{125}$

The LIII Corps was advised of strong enemy forces in Beschenkowitschi and in Ssenno. German units were still located east of Tschaschniki. Luftwaffe reports indicated at $1235 \mathrm{hrs}$ that German infantry were crossing over the Tschernogosthiza in the Tiger line $3.5 \mathrm{~km}$ south of Budilowo. The LIII Corps continued to request air cover and reported that the breakthrough had reached the line Balbarody-Ossniki (see Figure 91).126 The situation at 
Ostrowno remained unclear. German troops were extremely exhausted and there were shortages of ammunition. The 206th Infantry Division reported that the mass of the division was presently resisting Soviet attacks $8-10 \mathrm{~km}$ southeast of Vitebsk. 127 The 246th Infantry Division was located west of the 206th Infantry Division.

The LIII Army Corps had essentially been split into two groups (see Figure 92). The first group contained two regiments of the 6th Luftwaffe Field Division and the 206th and 246th Infantry Divisions surrounded southwest of Vitebsk. ${ }^{128}$ The second group contained units of the 4th Luftwaffe Field Division, one regiment from the 6th Luftwaffe Field Division, and units of the 246th and 197th Infantry Divisions encircled north of Ostrowno. ${ }^{129}$ The Germans launched 22 counterattacks in a desperate attempt to breakout to the west. ${ }^{130}$ Lt. General Peschel lead elements of the 6th Luftwaffe Field Division out of the pocket more than $15 \mathrm{~km}$ to the southwest into a swampy area. ${ }^{131}$ The 206th Infantry Division Headquarters was moved to Teljatniki (4 km west of Vitebsk) at $0200 \mathrm{hrs}$. Later, the Division Headquarters was transferred to a bunker 300 meters west of Pawlowitschi (see Figure 93). ${ }^{132}$ Major Voss, an officer of the 206th Infantry Division Headquarters staff reported that the LIII Corps Headquarters and General Gollwitzer during the afternoon were located in a concrete bunker 500 meters south of the village Baschki (see Figure 93). ${ }^{133}$

General Gollwitzer received a radio message from 3rd Panzer Army Headquarters inquiring what the situation was around 
Vitebsk. A half-hour discussion did not produce a clear formulation of a response to the Army Headquarters. Lt. General Hitter of the 206th Infantry Division did not intend to follow Hitler's order to stay in Vitebsk. His Division Headquarters was already on the southern edge of the city. He concentrated his units for a breakout in the evening before the village of Sarudniza. The Lutschessa strongpoint continued to be held (see Figure 93). The 206th Infantry Division had concentrated its forces for a breakout to the south. The supplies of the division which had been concentrated in one area were for the most part completely destroyed and burned by a Soviet air attack. ${ }^{134}$ The 206th Infantry Division and LIII Corps Headquarters assembled at $2200 \mathrm{hrs}$ with approximately 2000 men which were divided into battle groups of 500 men each. General Gollwitzer's final instructions were:

Men, we must still force this breakthrough, you must not let your General down. ${ }^{135}$

The attack proceeded with yells of "Hurra" and shooting into the Soviet outposts. German casualties were terrible. Major Voss reported that he and other officers stopped this form of attack and proceeded with the last units silently against the enemy. The breakthrough succeeded in passing through the village of Sarudniza and past the first Soviet security line in the early morning hours of June 27th. Major Voss lead one attack group through behind an assault gun and reached the woods before the village of Schelky. ${ }^{136}$ General Gollwitzer and Hitter had remained behind in Vitebsk. 137 
4th Army

VI and XXVII Army Corps. The Soviets had crossed the PskovKiev (PK) road and had advanced $8 \mathrm{~km}$ further to the southwest. There were wide gaps in the defensive line between the divisions of both corps. Between the 78th Assault Division and the 256th Infantry Division there was a gap. A gap also existed between these divisions and the 14th Infantry Division. Between the divisions of the XXVII Corps and the VI Corps there was a wide gap. ${ }^{138}$ Smoljany was lost and Soviet armor was already south of Obolzy (see Figure 94 ) and entering Ussweika $(6 \mathrm{~km}$ southwest of Obolzy). Major Weger of the 14th Infantry Division reported that VI Corps was no longer holding and radio communications had been lost. The 14th Infantry Division was building a new defensive front northeast of Kochanowo.

Lt. General Krebs informed the 4th Army at $0820 \mathrm{hrs}$ that the Soviets had ripped a hole $50 \mathrm{~km}$ wide between the $\mathrm{VI}$ and IX Army Corps and were advancing with motorized infantry and armor through this opening (see Figure 94). ${ }^{139}$ The Soviets were now advancing through Ssenno and to the southwest. Lt. General Krebs stated that it was impossible to close this hole and moreover a breakout attempt by the LIII Army Corps in Vitebsk had failed. The 4th Army was informed that it would have to give up one of its assault gun brigades for use by the Army Group.

Meanwhile, General Voelckers of the XXVII Army Corps reported heavy fighting on the east front of his corps and in Dubrowno (see Figure 95). During the late afternoon the divisions 
were pulled back to the Orsha bridgehead. The left wing of the 78th Assault Division extended to the rail line at Chorobrowo (northwest of Orsha) and had no connection to the right wing of the VI Army Corps on the highway in Dubowoje. The XXVII Army Corps was ordered to hold the defense line Dnieper covering position-the Dnieper west of Gatkowschtschina-Chorobrowo and to close the gap to the right wing of the VI Army Corps. The Commander of the the 78th Assault Division, Lt. General Traut was in Orsha where he was appointed Commandant of "Fortress Orsha" by the Fuehrer and ordered to defend it. 140

Radio communications were restored to the VI Corps at 0915 hrs and the 95th Infantry Division was reported at Sserkuti (18 km southeast of Ssenno). The VI Corps was ordered to defend the line Leschewo (12 km northwest of Kochanowo)-UssweikaGarneweschtschina Bridge (4 km west of Garneweschtschina). According to a report from the the 14th Infantry Division that had been fighting at Boguschewskoje the 256th Infantry Division had been surrounded and Lt. General Wuestenhagen was killed leading the breakout. ${ }^{141}$ VI Army Corps was also to establish a connection to the 14th Infantry Division to their east. General Metz was assigned to organize and scrape together any forces in the area of Tolotschin to form a coherent defense. ${ }^{142}$ Aerial reconnaissance reported 40 Soviet tanks advancing from the northeast through Obolzy toward Tolotschin (see Figure 94). VI Corps was instructed to send a Tiger tank battalion and an artillery battalion to 
Tolotschin. VI Corps was to reestablish communication to the right wing of the 3rd Panzer Army at Lukowskoje Lake.

The XXVII Corps requested that Orsha be abandoned as a "fortified position." General von Tippelskirch responded at 1935 hrs that Orsha was to remain a "fortified position" and that Lt. General Traut of the 78th Assault Division was to be the fortress commander. ${ }^{143}$ The main attacks against Orsha came from Soviet forces with armor. The Soviets had reached the northeast and north edge of the city. Soviet units were now even west of the city. The XXVII Corps was defending the "Bear, position including "Fortress Orsha" and also trying to prevent an advance by Soviet forces past Orsha to the west and south. 144 "Fortress Orsha" was to be held against all enemy attacks. The XXVII Corps continued to hold Kopys and Ustje west of the Dnieper Bridgehead.

The VI Corps was attacked between Smoljany and Tschereja and pushed back over the highway. In the afternoon, Kochanowo and Tolotschin were under attack (see Figure 94). The Soviet forces advancing further to the west received a radio message to rapidly occupy the Berezina crossings. ${ }^{145}$ The 256th, 14th and 299th Infantry Divisions were no longer considered unified, combat effective units. The VI Corps reported that 40 Soviet tanks had reached Tolotschin (see Figure 94). Units of the 95th Infantry Division were arriving with the beginning of the infantry column in Tolotschin trailing back to Wygoda. Elements of Tiger Tank Battalion 505 were also sent to defend Tolotschin. Soviet mobile units captured Kochanowo and proceeded past Tolotschin cutting 
the rail line and highway to Orsha (see Figure 94).146 The XXVII and VI Corps were forced to rely on the Belynitschi-Berezina road for supplies. Unfortunately, this road also traversed heavily partisan infested terrain.

XXXIX Panzer Corps. The XXXIX Panzer Corps reported that the 31 st and 12th Infantry Divisions and part of the Panzer Grenadier Division "Feldherrnhalle" were now in the Dneiper covering position. The Corps reported that the Soviets had crossed the Dnieper between Mogilev and Schkloff (see Figure 94). General Tippelskirch foresaw his army being cut off if it remained in the Dnieper covering position and the Orsha bridgehead. He requested at $0920 \mathrm{hrs}$ to withdraw his Army to the "Bear position" on the west bank of the Dnieper River.147 Lt. General Krebs, however, did not have the authority to authorize the withdrawal. General Tippelskirch was informed that $\mathrm{OKH}$ would propose a withdrawal to the "Bear position" for tonight.

The situation had become even more acute by noon. The 31st and 12th Infantry Divisions were under attack by superior Soviet forces. The Panzer Grenadier Division "Feldherrnhalle" was thrown back to the west. The XXXIX Panzer Corps was ordered at the onset of darkness to withdraw behind the Dnieper River because the Soviets may reach the Lupolowo bridge at Mogilev before the German troops could. General Tippelskirch assembled his generals at XXXIX Panzer Corps Headquarters and informed them that there could no longer be any delays. The Army would withdraw tonight behind the Dnieper River into the "Bear line" (see Figure 96). ${ }^{148}$ 
Rear Guards were to hold the bridgehead position east of Mogilev until the other troops had crossed the river whereupon they could then also withdraw behind the Dnieper River. The Soviets late in the afternoon broke into the Dnieper covering position. General Tippelskirch withdrew his headquarters between 1600-1800 hrs from Gadowitschi to Knjashizy (13 km northwest of Mogilev) (see Figure 94). 149

The 4th Army leaders questioned the holding of Orsha and Mogilev as "fortified places." However, General Tippelskirch continued to maintain that these cities must be held. A new development occurred on the right wing of the XXXIX Panzer Corps where the Soviets broke through the Dnieper covering position and had reached the Tschaussy-Mogilev rail line. The Soviets were also $12 \mathrm{~km}$ east of Mogilev (see Figure 94). Between Mogilev and Schkloff the Soviets were crossing the Dnieper River in two places with armor and infantry (see Figure 94).150 There were 12 Soviet divisions located in this breakthrough area.

Despite the present circumstances, the XXXIX Panzer Corps was ordered to defend the "Bear line" and clear up the Soviet breakthroughs west of the Dnieper River. In case of a Soviet breakthrough of the "Bear line" then "Fortress Mogilev" and "Fortress Orsha" were to be defended and held against all Soviet attacks.

XII Army Corps. This corps had assembled the strongest units of the 18th Panzer Grenadier Division south of Mogilev which were 
to be used to assist the XXXIX Panzer Corps in the battle north of the city. The XII Corps was ordered to hold the "Bear line."

Thus, in the 4th Army sector the Soviets had crossed the Dnieper River north of Mogilev and were encircling Orsha from the north and west. It was impossible to establish a new front north of the Minsk-Smolensk highway. The Soviets had crossed the rail line and highway on a wide front between Orsha and Tolotschin. (see Figure 94). The Soviets were in a position to widen their breakthrough on the deep left flank of the 4th Army.

\section{9th Army}

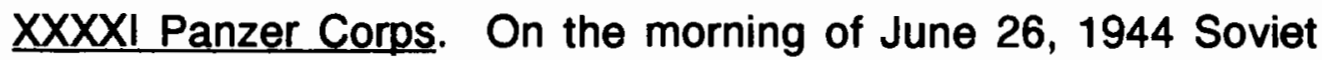
tank spearheads had penetrated to within $20 \mathrm{~km}$ of Bobruisk advancing from the south. ${ }^{151}$ The 20th Panzer Division was ordered to break off its engagement east of the Berezina River and regroup in the area west of Bobruisk. A new defense line was to be built southwest of Bobruisk. However, the bridge near Glebowa Rudnja was blown up because of approaching Soviet tanks leaving the 20th Panzer Division trapped on the east bank of the Berezina River. ${ }^{152}$ This left only the Berezina crossing at Ugly-Stassewki which was under heavy Soviet air attack. ${ }^{153}$ 20th Panzer Division moved toward this crossing and in the evening encountered a Soviet armor column at Titowka ( $3 \mathrm{~km}$ east of Bobruisk) (see Figure 97) containing 10-15 Joseph Stalin heavy tanks. ${ }^{154}$ These heavy tanks blocked the further Advance of the 20th Panzer Division into Bobruisk. 
Meanwhile, the 36th Infantry Division continued to hold the Paritschi area west of the Berezina River and Army Group Center ordered it to hold its position in order to block Soviet advances along the river bank road. However, this was unnecessary since the Soviets had already penetrated south of Paritischi to within $20 \mathrm{~km}$ south of Bobruisk. The Soviet armor spearheads were within $5 \mathrm{~km}$ of the city by late afternoon.

General Jordan was relieved of his command around noon to report to Field Marshal Busch. ${ }^{155}$ Field Marshal Busch and General Jordan were to report to the Fuehrer immediately. ${ }^{156}$ General Weidling, Commander of the XXXXI Panzer Corps was to assume command of the 9th Army temporarily. ${ }^{157}$

XXXV Army Corps. The 383rd Infantry Division was ordered back to Bobruisk immediately. The 707th Infantry Division was engaged in fighting around Buda. The 9th Army repeated its request to pull back the entire front of the XXXV Army Corps even though it was probably too late. The Soviets had at least 15 Rifle Divisions and several other tank formations operating in the corps sector. Soviet armor was concentrated during the afternoon $20 \mathrm{~km}$ northeast of Bobruisk near the Bobruisk-Mogilev highway. The withdrawal of the front was still not permitted by the High Command. The order was "not one step back without pressure."158 The 134th Infantry Division was essentially destroyed under the weight of the Soviet attack. ${ }^{159}$

LV Army Corps. This corps was thrown back on the Ptitsch sector. Between the corps left flank at Glusk and Bobruisk was a 
gaping hole through which the Soviets were pouring reinforcements. 160

During the night of June 26-27, 1944 the encirclement of Bobruisk was nearly completed. Soviet General Pliev's Cavalry Mechanized Group took Glusk and the 1st Tank Corps took Glusha. ${ }^{161}$ General Panov's 9th Tank Corps moved from Titowka and proceeded around Bobruisk to seize all the roads and crossings northeast of the city during the early morning hours of June 27, 1944 (see Figure 98). 162

Major Klassen of the 383rd Infantry Division in his report on the collapse of the 9th Army blames the 9th Army Commander and Major General Hamann for the debacle at the Titowka road junction. Major Klassen claimed that the high command had since November 1943 the opportunity to build defensive positions to protect the railway and road bridge into Bobruisk. ${ }^{163}$ He claimed that other defensive positions had been established at other points but not at this crucial position. Furthermore, after the Soviets had achieved a deep breakthrough at Mogilev with armor it was incomprehensible that the Commandant of Bobruisk did not take action to secure the bridgehead east of Bobruisk immediately. $164 \mathrm{He}$ also claimed that the 20th Panzer Division was not aggressive enough when it encountered Soviet armored resistance blocking the road to the bridge. Therefore, the Soviets on June 26th were able to block the road junction at Titowka with Joseph Stalin heavy tanks, (see Figure 99) the road bridge into Bobruisk with 3 tanks, and also bring the railway bridge into Bobruisk under fire. 165 
JUNE 27, 1944

\section{3rd Panzer Army}

The 212th Infantry Division was assigned to assemble in Lepel and maintain contact with Army Group North. The last radio message was received from the LIII Army Corps concerning the breakout from Vitebsk. The possibility of a breakout succeeding was questionable because there was an $80 \mathrm{~km}$ distance to cover to reach German lines. ${ }^{166}$

IX Army Corps. Tschaschniki was lost to Soviet artillery bombardment and armor. The Soviets broke through the IX Corps defensive line south of Ussweja Lake and were advancing northwest to Ossinowka. The bulk of the 212th Infantry Division had unloaded in Lepel. Lt. General Krebs notified 3rd Panzer Army that its units needed to hold their present positions. Major General Heidkaempfer advised Krebs that the 3rd Panzer Army had only 2 divisions left intact. ${ }^{167}$ Soviet infantry entered Bobrowo and Soviet armor entered Sslobodka. Kampfgruppe Monteton reported a breakthrough on its right flank. Assault guns were on the way to restore the situation, but road congestion made movement difficult. The Soviets were gaining ground against the 201st Security Division south of Ssokolskoje Lake (see Figure 100). The line of lakes at Ssusha was lost. The Soviets reinforced their breakthrough area with armor south of Ussweja Lake. Kampfgruppe Monteton reported at $1530 \mathrm{hrs}$ two Soviet breakthroughs at Tjapino 
and Newgodowo. The Soviet main effort against the 3rd Panzer Army was reported at Bobrowo on the road at $1630 \mathrm{hrs}$.

Col. General Reinhard informed Field Marshal Busch that the front of the 252nd Infantry Division between the lakes had disintegrated (see Figure 100). The Soviets broke through Ussaja to the south and then swung north up to Kriwuschino. There was a discussion over whether to deploy the 212th Infantry Division in the north and maintain contact to Army Group North or deploy it in the south to assist the 4th Army in its breakout. Field Marshal Busch ordered the 212th Infantry Division to the north to maintain contact with Army Group North. 168 Lepel was to be held under all circumstances. This jeopardized Kampfgruppe von Monteton's northern wing. The Soviets by 2000 hrs had already taken Sslobodka and Gluschiza while advancing toward Tettscha. Meanwhile, the 212th Infantry Division served as a reserve to hold Lepel (see Figure 101).169 The entire 3rd Panzer Army now consisted of two shattered divisions, security troops pulled from anti-partisan operations, and stragglers from the Vitebsk area. 170

LIII Army Corps. The last message from the LIII Corps was sent by General Gollwitzer at 0345 hrs on June 27, 1944 which stated:

Night breakout under personal leadership of Corps Commander has started well. By $0300 \mathrm{hrs}$ several enemy positions penetrated at three places. We are fighting for Sarudniza. What is the enemy situation on the VI and IX Army Corps sectors and the best route to take from Sadaroshye? Continuous fighter cover is requested. 171 
The 3rd Panzer Army continued to transmit the best direction to breakout throughout the entire day. However, there was no confirmation of the message by the LIII Corps or the 206th Infantry Division by radio.

Lt. General Peschel personally lead the breakout of elements of the 6th Luftwaffe Field Division and died during the attempted breakthrough to German lines. ${ }^{172}$ Lt. General Pistorius lead elements of the 4th Luftwaffe Field Division in a breakout to the west and died on June 28th during the march through the area of Gankowitschi-Rwesh. 173

On the morning of June 27, 1944 the end finally came for the LIII Army Corps. The Soviets issued an ultimatum to surrender and the remnants of the German divisions accepted it. The following German losses were recorded by Soviet sources:

The enemy suffered 20,000 dead and over 10,000 taken prisoner near Vitebsk. The Commander of the 53rd Army Corps, General of Infantry Gollwitzer and Chief of Staff of that corps, Colonel Schmidt were taken prisoner. 174

Lt. General Hitter of the 206th Infantry Division was also taken prisoner. 175 However, he had defied Hitler's order to stay in Vitebsk and had attempted a breakout which had advanced about 9 miles before it ended with a bayonet charge by the East Prussian 301st, 312th and 413th Grenadier Regiments. ${ }^{176} \mathrm{~A}$ few desperate groups of men did manage to elude the Soviets and make it back to German lines. 
The 246th Infantry Division dissolved in this cauldron and the Division Commander, Major General Mueller-Buelow was taken prisoner. ${ }^{177}$ The 197th Infantry Division which had been attached to the LIII Corps when the VI Corps had been pushed to the south also disintegrated and the commander Colonel Hahne was missing in action. 178 The LIII Army Corps had ceased to exist which meant Army Group Center had lost the following 5 divisions:
4th Luftwaffe Field Division
6th Luftwaffe Field Division
197th Infantry Division
206th Infantry Division
246th Infantry Division. 179

\section{4th Army}

The XII Army Corps pulled back into the "Bear" line. The XXXIX Panzer Corps was under heavy pressure and the Soviets had achieved a deep breakthrough north of Mogilev. Orsha in the XXVII Corps sector was under attack from all sides. The 78th Assault Division still held the center of Orsha. ${ }^{180}$ There was no contact to the VI Army Corps. The 4th Army wanted to abandon the fortified places of Orsha and Mogilev, but Army Group Center High Command demanded that "Fortress Orsha" and "Fortress Mogilev" were to be held to the last under all circumstances. 181 The 4th Army Headquarters was transferred to Belynitschi.

XXVII Army Corps. Soviets were already attacking the corps in the rear. "Fortress Orsha" was lost to the Soviets. ${ }^{182}$ Soviet armor and cavalry forces in the area of Krugloje were advancing 
south (see Figure 102). The 4th Army requested to abandon the Dnieper position and fight through to the west or it would have to permit strong units to be encircled. Army Group Center responded with orders for 4th Army at 1145 hrs which continued to insist that the Dnieper position and the fortified places were to be held. If the Dnieper position had to be abandoned then the fortified places would still have to be held and the Drut River position defended. Finally, at $1505 \mathrm{hrs}$ a general withdrawal of all 3 corps of the 4th Army was permitted. The XXVII Army Corps was to fight its way back to the line Osery-Starosselje-rail station Kochanowo with contact to the right wing of the 14th Infantry Division in the area llinka (12 km southeast of Tolotschin). The 25th Panzer Grenadier Division and the 260th Infantry Division fought through to Starosselje (see Figure 102).

"Fortress Orsha" had been lost and Field Marshal Busch inquired of General Tippelskirch how this designated "fortified place" had been lost. Apparently, Lt. General Traut, Commander of the 78th Assault Division and Commandant of "Fortress Orsha" had requested permission to withdraw from Orsha and the XXVII Army Corps granted this request only after the Soviets had broken into Orsha and bitter street battles had developed. ${ }^{183}$ Lt. General Traut claimed that under Fuehrer Order No. 11 as Commander of a "Fortress" he "must have enough time" to assign his troops within the defensive position (see Appendix $C$ ). Therefore, the positioning of his troops was not possible because the Soviets had already broken into Orsha from the north and northwest as the 
troops of the 78th Assault Division entered the city. ${ }^{184}$ Lt. General Traut based his decision to withdraw from Orsha given the unfavorable circumstances and used his interpretation of Fuehrer Order No. 11 to save his troops from encirclement inside "Fortress Orsha." (see Figure 103). Meanwhile, southwest of Orsha Krugloje was taken by Soviet armored units.

VI Army Corps. This corps had been broken apart and only isolated individual units continued fighting. 185 Remnants of the $\mathrm{VI}$ Corps assembled in the area south of the highway at Krugloje.

XXXIX Panzer Corps. The Soviets achieved a deep breakthrough north of Mogilev. The Soviets at $1040 \mathrm{hrs}$ were reported crossing the Dnieper north of Mogilev over a new bridge at Trebuchi.186 The 110th Infantry Division reported that it was being attacked in the rear on the west bank of the Dnieper River. The 4th Army sent a radio message at $1210 \mathrm{hrs}$ to Major General Erdmannsdorf, Commandant of Mogilev that Mogilev remained a "fortified place" and was to be held to the last. ${ }^{187}$ The Army Group Headquarters reinforced this order at 1515 hrs by declaring that "Mogilev remains a fortified place." Lt. General Bamler of the 12th Infantry Division was appointed new Commandant of Mogilev and required to obey Fuehrer Order No. 11 (see Appendix C). ${ }^{188}$ The 4th Army had decided to withdraw the XXXIX Panzer Corps and the XII Army Corps $21 \mathrm{~km}$ to the west of Mogilev leaving it to stand alone against the Soviet onslaught. The corps were to withdraw to the line Wjasma-Gamarnja-Gluchi-Shurawes-Golowtschin-north of Osery (10 km southeast of Krugloje). 
Major General Erdmannsdorf reported at 1920 hrs that the Soviets after strong artillery preparation at noon attacked Mogilev from the south, east and north.189 Weak German forces were unable to prevent the river crossing in the east and this battle was now being waged on the city's outskirts as a result (see Figure 104). Two hours and 40 minutes later at 2200 hrs Major General Erdmannsdorf reported that only the city center of Mogilev was being held by the determined hand to hand combat of officer Kampfgruppen. 190 The last message from "Fortress Mogilev" was sent at $2200 \mathrm{hrs}$ and received at $2314 \mathrm{hrs}$. Lt. General Bamler in this message requested that Captain Opke of Artillery Regiment 12 receive the oak leaves to the Knights Cross for repeated outstanding military exploits. This was the last sign of life from Mogilev. 191

XII Army Corps. This corps was pulled back to the "Bear" line. The XII Corps had assembled strong forces behind its left flank to assist the XXXIX Panzer Corps to close the hole that would be left by leaving behind the garrison in Mogilev. The XII Corps reported at 1515 hrs that the Soviets on their right flank had advanced through Ussochi and reached the village of Bazewitschi $(26 \mathrm{~km}$ north of Bobruisk). This meant that the 4th Army was now threatened by encirclement from the south as well as the north (see Figure 105).

The 4th Army ended the day in serious trouble. Orsha had been lost. The Soviets had penetrated behind the Dnieper river between Mogilev and Schkloff and reached the area east of Golowtschin. The city center of Mogilev was all that remained 
under German control. The XXVII Corps had been outflanked in the north and split into two parts. The VI Corps in the north had mostly disintegrated with the exception of the 299th Infantry Division. General Tippelskirch shortly before midnight issued the following declaration:

Thanks and recognition to all brave veterans in the severe battle against every cowardly act of malingering. The Russian offensive and defensive must be fought with all means then we will succeed. ${ }^{192}$

Tippelskirch was now appealing to his soldiers as individuals for acts of heroism to compensate for the blunders of the High Command.

\section{9th Army}

In the early morning hours of June 27, 1944 Bobruisk was encircled by Soviet forces. Approximately 70,000 troops were trapped in the cauldron around Bobruisk. ${ }^{193}$ Soviet forces were now on the road to Ssluzk, Nowyje Dorogi, and toward Ossipowitschi (see Figure 106). The 296th, 6th, and 45th Infantry Divisions were fighting their way back to a bridgehead $4 \mathrm{~km}$ east of Bobruisk. These units were trapped on the east side of the Berezina River with the Soviet thrust into their rear and the blocking of the Berezina bridge east of Bobruisk (see figure 107).

The 383rd Infantry Division and the 20th Panzer Division succeeded partially in their attack toward Titowka. The Germans were unable to take the wooden road bridge, but they did seize the 
railway bridge and managed to keep it open (see Figure 108). ${ }^{194}$ German troops had one exit from the east bank of the Berezina River and that was over this railway bridge. A steady stream of vehicles and troops poured into Bobruisk over this railway bridge. The XXXXI Panzer Corps wanted to get the 36th Infantry Division and the remaining elements of the 20th Panzer Division into Bobruisk. Therefore, a final assault to seize the wooden road bridge was launched and failed. ${ }^{195}$ Most of the armored elements of the 20th Panzer Division were lost. ${ }^{196}$ Chaos then reigned around the railway bridge as vehicles and guns were destroyed in a desperate attempt to escape to the west bank of the Berezina River.

The Soviet 16th Air Army flew continuous air attacks against the two pockets created at Bobruisk: the XXXXI Panzer Corps in Bobruisk and the XXXV Corps trapped on the east side of the Berezina River (see Figure 108). Marshal Zhukov witnessed the carnage of this battle of annihilation:

I was not able to see the liquidation of the enemy in Bobruisk, but witnessed the rout of of the Germans southeast of the city. Hundreds of bombers of Rudenko's 16th Air Army, coordinating missions with the 48th Army, struck blow after blow at the enemy group. Scores of trucks, cars and tanks, fuel and lubricants were burning all over the battlefield. More and more bomber echelons took their bearings from the blazing fires, and kept dropping bombs of various weights.

The terror-stricken German soldiers scattered in every direction; those who did not surrender were killed. 
Thousands of Germans...were dying in the fields of Byelorussia. One of our prisoners was General Luetzow, Commander of the 35th Army Corps. 197

According to Marshal Rokossovsky, Commander of the 1st Belorussian Front the Germans launched no less than 15 counterattacks against Titowka on June 27, 1944.198 However, the Soviet 9th Tank Corps and the 108th Rifle Division prevented a German breakthrough across the road bridge into Bobruisk. ${ }^{199}$ General P.A. Teryomov, Commander of the 108th Rifle Division described the fiercest German attack in this sector:

About 2,000 enemy officers and men supported by fairly strong artillery fire attacked our positions. Our guns opened fire from a range of 700 meters, and machineguns joined in from 400 meters. The Nazis continued to advance. Shells exploded in their midst, machine-gun fire mowed them down. Still they came forward, stepping over the bodies of their men. They came on blindly. It was a mad attack. We saw the whole terrible.picture. There was nothing heroic in it. The Nazis seemed in a state of trance. There was in the movement of this huge mass of men more of the mulish stubbornness of the herd than of fighting men intent on forcing their will on the enemy at all costs. Nevertheless, the sight was an impressive one.200

Germans suffered terribly under Soviet airpower. The German troops in the Dubovka area southeast of Bobruisk were pounded by 526 aircraft for one hour. Marshal Rokossovsky stated:

The Nazis ran out of the woods, rushed about the clearing, many of them dived into the Berezina, but there was no escape. The whole area soon began to look like a huge graveyard strewn with mauled bodies and mangled machines. 201 
During the two day onslaught the Germans suffered more than 10,000 dead and 6,000 prisoners were taken which eliminated the German pocket southeast of Bobruisk.202

XXXV Army Corps. The 134th Infantry Division and elements of the 707th Infantry Division were forced back to the Ola River near Batsevichi. When the remainder of the corps could not get through at Titowka then it began to move north to meet the 134th Infantry Division at the Ola River. Lt. General Phillip, Commander of the 134th Infantry Division committed suicide under the pressure of the situation (see Figure 107).203 General Freiherr von Luetzow lead the XXXV Corps from the area of Mikhaylevo $(15 \mathrm{~km}$ east of Bobruisk) toward the Mogilev-Bobruisk road. He was later captured by the Soviets. 204

LV Army Corps. The corps was conducting a defense behind the Ptich River. The 35th Infantry Division located $15 \mathrm{~km}$ southwest of Berezorka was reduced to a few remnants. The corps was ordered to conduct a phased withdrawal at $1630 \mathrm{hrs}$ to the new defense line Star-Dorogi-Lake Chervonoye. The LV Corps was placed under command of the German 2nd Army at $1800 \mathrm{hrs.} 205$ The 2nd Army also assumed command of "Fortified Places" Slutsk and Baranovichi.

The only relief for the 9th Army was the arrival of the 12th Panzer Division from Army Group North that was to assemble at Marina Gorka.206 The 390th Field Training Division and some security formations were to provide cover for this deployment. Gruppe Lindig consisting of ad hoc units, retreating troops, troops 
on leave, fragmented units, and railroad security forces attempted to hold Ossipowitschi but were thrown back during the evening. 207

$$
\text { JUNE 28, } 1944
$$

\section{3rd Panzer Army}

IX Army Corps. In the sector of Corps Detachment $D$ the Soviets broke through onto the Kamen-Lepel road, $2 \mathrm{~km}$ southwest of Kamen. The 252nd Infantry Division reported the Soviets in the woods west of Olschany and on the road east of SlobodaTscherstwjany which the division was blocking The Soviets had been attacking the city of Lepel since $0530 \mathrm{hrs}$ and had broke into the city with 12 tanks and occupied the rail station with 4 tanks (see Figure 109).208 Lt. Colonel Ottow, the Commander in Lepel reported at $0900 \mathrm{hrs}$ that his command post had been moved to the western exit of Lepel and that he would hold a bridgehead east of the Essa River. 209 Gruppe von Monteton simultaneously reported that the Soviets with tank mounted infantry had forced their way into Lepel and the battle in the city was still raging (see Figure 109). During the morning Soviet armor was reported $30 \mathrm{~km}$ south of Lepel near Studenka moving west. Major General Heidkaempfer requested that the Army Group hold the Beresino bridge northwest of Begoml. The bridges over the Essa River west of Lepel at 1230 hrs were reported to have been blown up. During the afternoon the Soviets attacked the west bank of the Essa River. The battles for Lepel and the west bank of the Essa River were continuing as of 
$1800 \mathrm{hrs}$. The IX Corps was holding the line Woron-Uschatschi.

The 212th Infantry Division was holding a position southwest and west of Lepel (see Figure 109). The corps was withdrawn to Ssamoschje when 30 Soviet tanks emerged at Uschatschi. The hole at Woronetsch to the right wing of the 16th Army was now approximately $12 \mathrm{~km}$ wide and the 3rd Panzer Army lacked the forces to close this hole.210 Field Marshal Busch informed Colonel General Reinhardt shortly before midnight that Field Marshal Model had taken over the command of Army Group Center.211

\section{4th Army}

VI Army Corps. The corps with the 299th and 14th Infantry Divisions recaptured Krugloje. General of Artillery Pfeiffer, Commander of VI Army Corps was killed in an air attack about 2000 hrs outside of Mogilev. 212

XXVII Army Corps. The Army Group ordered the corps at 1000 hrs to begin a withdrawal behind the Drut River and to anticipate a further withdrawal to the Berezina River. The 14th Infantry Division was assigned to the XXVII Corps since it was in the corps sector. General of Infantry Voelckers, Commander of XXVII Corps reported at $0800 \mathrm{hrs}$ strong Soviet forces between StarosseljeGorodok. The most distant elements of the corps had crossed through Teterin and reached Shittja (1 km west of Kamenka) and Tschirtschin. General Voelckers reported that his command post was at Tschirtschin.213 The XXVII Corps reported a successful breakthrough at Troiza (south of Starosselje) to the southwest. 
Soviet air attacks impeded the movement of the XXVII Corps. The 260th Infantry Division was forced out of Starosselje. The 25th Panzer Grenadier Division was fighting on all sides (see Figure 110). Soviet armor was again forcing their way from the north into Krugloje at 1245 hrs. Stuka aircraft support was requested. The corps received the order at midnight to cross the Berezina River. The bridge at Wydriza (36 km east-southeast of Borisov) was reported blown up and air supply was requested.

XXXIX Panzer Corps. The corps received the order to withdraw behind the Drut River beginning in the evening and to anticipate a further withdrawal to the Berezina River.214 The 5th Panzer Division which was unloading in Borisov reported that yesterday Soviet armor with infantry loaded in trucks were in the rear of the corps moving south of Bobr on the rail line.215 Soviet forces were also south of Sseljawa Lake advancing southwest toward Chatjuchowa. The 5th Panzer Division was engaging these forces (see Figure 110) and had the impression that the Soviets were attempting to seize the Berezina River crossings at Ziembin and Borisov.

The Commander of the XXXIX Panzer Corps, General of Artillery Martinek was killed in a Soviet air attack on a road back to the Berezina River.216 German troops were subjected to continuous Soviet air attacks all along the roads leading back to the Berezina River (see Figure 111).217 The Army Group recognized that with deep breakthroughs on both flanks of the 4th Army that the Berezina crossing at Beresino was threatened. Soviet armor 
was driving directly southeast of the Berezina River and had entered Sseliba and Brodez. General Tippelskirch ordered that a bridgehead east of the Berezina River be held to prevent the Soviets from crossing the river. The main road to Beresino was crucial so the XXXIX Panzer Corps concentrated its anti-tank forces on the road to prevent a Soviet armor breakthrough onto the road. The 27th Fusilier Regiment of the 12th Infantry Division was dispatched immediately to Beresino where the bridge had been under continuous air attack since 1100 hrs. ${ }^{218}$ The 27th Fusilier Regiment had been cutoff from Mogilev by the Soviet offensive thereby surviving the onslaught against Mogilev.

Meanwhile, there had been no reports from Mogilev since $2200 \mathrm{hrs}$ yesterday. It was presumed that even the city center had fallen. Field Marshal Busch issued an order at 1245 hrs that permitted the 12th Infantry Division to abandon Mogilev. However, it was already too late for the 12 th Infantry Division. The 82 nd Grenadier Regiment of the 31st Infantry Division had also been encircled at Mogilev and suffered the same fate. ${ }^{219}$

XII Army Corps. The corps requested that a bridge be built over the Berezina River for its withdrawal. The 4th Army replied that a bridge at Perewos was being built. The corps received its order to withdraw behind the Drut River. It was also ordered to send a motorized, reinforced regimental group from the 18th Panzer Grenadier Division immediately to the Belynitschi-Beresino road to advance west and secure both sides of the Berezina River and cover the 4th Army right flank. The 31st Infantry Division was 
reported at 1000 hrs as already west of the Drut River. The rest of the corps was delayed by the construction of a bridge over the Drut River.220 The XII and XXXIX Panzer Corps were ordered to bring their headquarters to Beresino where the 4th Army Headquarters was located.221

On the left wing of the 4th Army a $100 \mathrm{~km}$ hole existed through which Soviet armor, trucks, and infantry were moving southwest (see Figure 110). The 5th Panzer Division which had just recently arrived by rail at Borisov was engaging the Soviet forces attempting to reach the Berezina River on the left flank of the 4th Army. Lt. General von Saucken was placed in command of a task force on the north wing of the 4th Army. The units comprising Gruppe von Saucken were: 5th Panzer Division, Heavy Tank Battalion 505, Gruppe von Gottberg, Gruppe von Altrock and staff from the XXXIX Panzer Corps Headquarters. ${ }^{222}$ Gruppe von Saucken was organized to block the advancing Soviet spearheads northeast of Borisov.

The 4th Army was threatened with being cutoff on the east side of the Berezina River (see Figure 110). The 4th Army Headquarters was moved to Beresino after a 9 hour journey by road which was under continuous Soviet air attack and burning vehicles and dead horses obstructing the road had to be removed along the route.223 General Tippelskirch requested fighter cover for the road. The road bridge at Beresino was subjected to 25 air attacks. ${ }^{224}$ The houses burning around the town and bridge of Beresino forced the 4th Army Headquarters to relocate to Shornowka (northwest of 
Beresino). Field Marshal Busch notified 4th Army Headquarters at 1530 hrs:

The overall situation calls for speedy continuation of the rearward movement to the Berezina River. All combat effective formations are to be transferred as fast as possible through Beresino to Borisov and Svisloch. 225

General Tippelskirch issued the order at $1745 \mathrm{hrs}$ to all three corps which stated: "Get to the Berezina. No time constraints."226

General Tippelskirch recorded in his diary that "now the order comes too late."227 Later that night Field Marshal Busch informed Tippelskirch that Field Marshal Model was taking command of Army Group Center. General Tippelskirch in his last conversation with Field Marshal Busch could not contain his bitterness over the development of the situation which resulted from the leadership of Army Group Center.228

\section{9th Army}

The 9th Army finally received approval from Adolf Hitler to abandon Bobruisk in the afternoon of June 28, 1944.229 The previous day Hitler had ordered that Bobruisk be held with the 383rd Infantry Division. However, when Bobruisk was encircled by at least 10 Soviet divisions Hitler granted the troops in Bobruisk freedom of action.230 Meanwhile, it was chaotic in Bobruisk which was under constant Soviet air attack. There was a lack of heavy weapons because the troops had destroyed them in their retreat into Bobruisk. Major Klassen of the 383rd Infantry Division 
reported the morale of the troops had been adversely effected by destroying their own equipment.231 The common soldier was reported as saying: "This Army has destroyed itself."232 The Commander of the 9th Army observed:

9th Army has virtually ceased to exist as a fighting force. It has not a single battleworthy formation left. 233

General of Armor von Vormann assumed command of the 9th Army under the present circumstances. ${ }^{234}$ Troops kept pouring into Bobruisk over the one open railway bridge over the Berezina River.

Meanwhile, on the right wing of the 9th Army the 35th Infantry Division which consisted of mere remnants was fighting its way back to Lyuban and the 129th Infantry Division was falling back behind the Plyusha River southeast of Albinsk. These two divisions had escaped encirclement. The 102nd Infantry Division was still fighting on the Ptich River.

Behind the encircled Bobruisk forces a new defensive line was established. Gruppe Lindig contained the 390th Field Training Division and the 12th Panzer Division which was unloading at Marina Gorka.235 Therefore, on a $140 \mathrm{~km}$ front between the German 4th and 2nd Armies only a $20 \mathrm{~km}$ frontage astride the Minsk road was defended with four security battalions, ad hoc units reinforced by assault guns and one-third of the 12th Panzer Division. ${ }^{236}$

Lt. General Hoffmeister of the XXXXI Panzer Corps planned the breakout from Bobruisk for the night of June 28-29, 1944 . During the day more than 10,000 soldiers in Bobruisk fought off Soviet 
attempts to break into the city. 237 Major General Hamann, Commandant of Bobruisk conducted an all-around defense of Bobruisk. There were gun emplacements in buildings, barricades in the streets, and tanks dug into the ground on street corners, and the city entrances were heavily mined. The German Command pulled back troops to the city center and concentrated large forces of Infantry, artillery and tanks in the northern and northwestern districts for a breakout attempt during the night. The German breakout would attempt to force the road in a breakout to the northwest in the general direction of Osipovichi.

JUNE 29, 1944

\section{3rd Panzer Army}

The 3rd Panzer Army consisted of the 212th Infantry Division, the remnants of Corps Detachment $D$, and the 252nd Infantry Division.238 Field Marshal Model asked Colonel General Reinhardt what forces he would need to maintain a continuous front to Army Group North. Reinhardt responded that the front could be maintained if Kampfgruppe von Saucken could help cover the southern flank.

In the south half of a Soviet battalion had crossed over the Berezina River in the morning fog. Two companies of Soviet infantry had already occupied the village of Brod west of the Berezina and $14 \mathrm{~km}$ south of the Lepel-Begoml road. The German engineers began destroying all the bridges over the Berezina River. 
The 3rd Panzer Army Headquarters moved to Borsuki in the morning. The 212th Infantry Division was pulled back to the Biber line with contact to the IX Corps through Zerkowischtsche (see Figure 112). The IX Corps reported at $1100 \mathrm{hrs}$ that Soviet armor was now in front of Gorodez and in front of the 212th Infantry Division and on both sides of the Plina road going north. On the Lepel-Kalnik road densely packed Soviet motorized formations were breaking through at Ssloboda to the north (see Figure 112). Luftwaffe air strikes were requested against Soviet armor and motorized columns on these roads: Karbany-Gorodez, UschatschiBogdanowo, and Uschatschi-Posselok. The Soviets at Brod were reported building a bridge at noon (see Figure 112). Northeast of Kublitschi on the left flank of the IX Corps the Soviets achieved two breakthroughs (see Figure 112). During the late afternoon the. 212th Infantry Division was withdrawn behind the Berezina line. Finally, a general withdrawal was ordered by the end of the day to the following defense line: west bank of the Ponja River from south of Dokszyce to the line of lakes north of Plissa Lake. ${ }^{239}$

\section{4th Army}

Field Marshal Busch informed the 4th Army at $1930 \mathrm{hrs}$ on June 28th that the Korpsgruppe von Saucken consisting of the 5th Panzer Division, Kampfgruppe Gottberg, Gruppe Altrock and other attached units were now under 4th Army command.240 The mission of Korpsgruppe von Saucken was to secure the deep north flank of 
the 4th Army so that it would be possible for the 4th Army to fight its way back behind the Berezina River.

General von Tippelskirch flew with his Storch aircraft in the morning to meet General von Saucken. On his return trip he flew out further to the east to get a picture of the situation east of the Berezina River. His plane was almost shot down near Wydriza (35 $\mathrm{km}$ southeast of Borisov) by ground fire.241 The Storch aircraft received several hits.

The Soviets had already crossed the Berezina River to the north in the area of Ziembin.242 The Army Group also reported 50 Soviet T-34 tanks on road at Bobr moving southwest. The 4th Army issued again the order to speed up the withdrawal and get behind the Berezina River. However, the bulk of the 4th Army with the XII Corps, XXXIX Panzer Corps, VI Corps, and XXVII Corps was not expected to be able to reach the Berezina River earlier than June 30,1944 because of the slow progress in the fighting withdrawal from the Drut River line (see Figure 113). ${ }^{243}$ The 4th Army like the 9th Army previously was threatened with being cutoff east of the Berezina River by the parallel advance of Soviet units (see Figure 113).

The Berezina River bridge at Beresino was to become a strategic position of decisive importance in the retreat of the 4th Army. It was now a high priority target for the Soviet Air Force. During the morning the bridge received a direct bomb hit which destroyed 10 meters of the bridge.244 The Army Engineer Commander reported at $1030 \mathrm{hrs}$ that the bridge could be repaired 
by $1700 \mathrm{hrs}$. Then the bridge received another direct hit at 1215 hrs which severely damaged 15 meters of the bridge. Nevertheless, German engineer troops worked rapidly under continuous air attack and reopened the bride to traffic at $1500 \mathrm{hrs.}{ }^{245}$ A ferry operation was also started. The congested roads leading to Beresino were under constant Soviet air attack. 246

VI Army Corps. The corps requested fighter cover for the Belynitschi-Beresino road because of the heavy losses suffered due to Soviet air attacks.

XXVII Army Corps. There had been no radio contact with this corps since noon on June 28, 1944.247 The 4th Army sent the corps radio messages briefing them on the bridges over the Berezina River at $0040 \mathrm{hrs}$ on June 30th. Radio contact was restored when the corps confirmed the message at $0315 \mathrm{hrs}$. The bridge at Tschernjawka was reported blocked by the Soviets. ${ }^{248}$ The bridge at Beresino and the footbridge at Shukowez were reported open.

XXXIX Panzer Corps. The corps reported that the withdrawal from the Drut River line was continuing and it would cross the Berezina River on both sides of Beresino and at Shukowez. The corps requested fighter cover for the Belynitschi-Beresino road. The corps reported at 1100 hrs that Traffic on the BelynitschiBeresino road had come to a complete stop since 0700 hrs. ${ }^{249}$ A Storch aircraft was requested to determine the cause of the traffic obstruction so measures could be taken to restore the flow of traffic. The corps advised the 4th Army that the fastest way to expedite the withdrawal would involve the loss of vehicles. 
Therefore, the corps in order to avoid such loss proposed all vehicles east of Beresino be driven off both sides of the road into the woods. The end of the column would then be able to get underway. A bridgehead east of Beresino could be established so that the vehicles could be parked within this bridgehead until they could be moved to the west side of the Berezina once the bridge at Beresino was operational. 250

Meanwhile, the 4th Army obtained further reports about an immediate threat to the Berezina River crossing at Beresino. The XXXIX Panzer Corps was informed at 1310 hrs that a Soviet force of unknown strength with artillery had been identified in the area 15 km southeast of Beresino (see Figure 113).

The Soviet forces pursued the retreating front from the east closely. The 110th Infantry Division reported at $1535 \mathrm{hrs}$ an attack by 40 tanks and infantry at Lichinitschi (south of Krugloje). The corps reported a Soviet breakthrough with armor and flak artillery northwest of Belynitschi. The German divisions were now locked into a race with the Soviets for the Berezina River.

XII Army Corps. The corps reported that the 18th Panzer Grenadier Division would not cross the Drut River until $1000 \mathrm{hrs}$. Lt. Colonel Reden reported at 0400 hrs that Soviet armor had not yet entered Brodez, but Soviet combat reconnaissance had reached the Berezina River at Jakschizy. ${ }^{251}$ Elements of the 9th Army were in this area. The dispersed 134th Infantry Division and the 707th Infantry Division were here. The 707th Infantry Division was ordered to the bridgehead at Brodez where bridge construction was 
in progress and two small ferries were in operation. The most western units of the XII Corps were ordered to proceed to the Berezina River sector south of Beresino where the 4th Army was threatened on its southern flank. .

The XII Corps reported that the 18th Panzer Grenadier Division had been delayed as of 0849 hrs and would not be across the Drut River before noon. The 57th Infantry Division was withdrawing from Ussakino (6 km west of the rail line) and the 267th Infantry Division was at Dulebo. Further east heavy traffic congestion was reported. The 31st Infantry Division was moving along two routes. The smaller part of the division was on the southern road at Kurpanje (8 $\mathrm{km}$ southeast of Pogost). The larger part of the division was on the northern road at Matschesk $(12 \mathrm{~km}$ southeast of Pogost). 4th Army Headquarters ordered the 31st Infantry Division at $1500 \mathrm{hrs}$ to destroy the Soviet force that was advancing against the main highway from the Wjas-KutinKlubtscha road.

The XII Corps received a radio message at $1730 \mathrm{hrs}$ declaring that Goroditsche (20 km south of Beresino) was occupied by Soviet forces.252 The 4th Army ordered the XII Corps at 1930 hrs to employ the 31st Infantry Division to protect the BeresinoBelynitschi road from the south once it reached the Berezina River. ${ }^{253}$ The 31 st Infantry Division was also ordered to send a regiment immediately through Beresino to Tscherwen. The 18th Panzer Grenadier Division was also ordered to send its armored reconnaissance vehicles immediately to the west edge of the 
Beresino. The situation at Beresino was growing more tense. The 707th Infantry Division reported Soviet armor followed by trucks loaded with infantry on the east bank of the Berezina River at Sseliba advancing north. The small brigehead at Brodez was still holding. It was only defended by rear service troops, an artillery battalion, and two anti-tank guns (Pak). It would attempt to hold the town but reinforcement with infantry and antitank guns (Pak) were urgently needed. One engineer battalion alone held both sides of Perewos.

The intensification of the crisis facing the 4th Army was evident by the end of June 29th. The Soviets had pursued the 4th Army closely during its withdrawal from the Drut River line. The Soviets had reached the Berezina River at Tschernjawka during the evening. 254 Soviet armor was advancing from the south toward Beresino (see Figure 113). The XII Corps had been ordered to expedite their withdrawal, but the corps was delayed because the crucial bridge at Beresino had been made impassable for several hours. The corps was trapped on the Belynitschi-Beresino road and consequently suffered from continuous Soviet air attacks against this main road for hours. 255 Lt. General Schuenemann, Commander of the 337th Infantry Division was killed during one of the Soviet air attacks on the Belynitschi-Beresino road. ${ }^{256}$ This was the third general killed within 24 hrs in the 4th Army. 257

Korpsgruppe von Saucken in the north was suppossed to hold the Soviets back north of the Minsk-Smolensk highway to facilitate the withdrawal of the 4th Army. However, the Soviets broke 
through Korpsgruppe von Saucken with strong motorized and armor units along both sides of the highway to the Berezina River. ${ }^{258}$ The bridgehead Borisov was held and the Soviets crossing the river northwest of Borisov were Repulsed at Studenka and Zembin by the 5th Panzer Division. 259

\section{9th Army}

The plan for the breakout from Bobruisk was laid out by the XXXXI Panzer Corp's orders which contained the following provisions:

1. The breakout was to be to the left of the road and directly west of the Berezina River in a general northern direction with the armored group of the 20th Panzer Division in front.

2. The remaining divisions would follow behind the right wing of the 20th Panzer Division.

3. The breakout would begin on June 28 th at $2300 \mathrm{hrs}$. Rear Guards were to hold their secure positions until 0200 hrs on June 29th.

4. Tracked vehicles, Volkswagen and riding horses were to be brought along but other vehicles and horses were to be destroyed.

5. The wounded would remain in Bobruisk under medical care. The 383rd Infantry Division and troops of "Fortress Bobruisk" were to gather the wounded and 
bring them to the citadel in Bobruisk to place them under medical care. 260

The first breakout attempt from Bobruisk was executed at 0130 hrs. ${ }^{261}$ The Germans concentrated artillery and mortar fire on the breakout sector to the northwest of Bobruisk. Officers formed skirmish lines followed by soldiers. The attack failed leaving 1000 Germans dead on the battlefield.262 The attack was resumed at $0200 \mathrm{hrs}$ and despite murderous fire from Soviet artillery and machine guns German troops broke through to the road toward Osipovichi.263 Meanwhile, the Soviets crossed the Berezina River and broke into Bobruisk at $0400 \mathrm{hrs}$ and the remaining German garrison was liquidated by 1000 hrs leaving the Red Army in possession of Bobruisk. 264

The 20th Panzer Division's Panzer Grenadiers succeeded in breaking through the Soviet lines during the night. The armored group of the division followed up this attack in a breakout in the region of Nasarowka against weak Soviet resistance to the north (see Figure 114). During the evening hours the 20th Panzer Division Kampfgruppe encountered strong Soviet resistance in a line between Luki and Schatkowo to the west. The Soviets were reinforcing the bridge at Schatkowo. German columns were fired upon by heavy weapons from the Schatkowo bridge area. This ceased with the German capture of Luki and Schatkowo (see Figure 114). The Germans proceeded to secure their right flank by shooting up the Schatkowo bridge with an $88 \mathrm{~mm}$ Flak gun rendering it unusable. 
Meanwhile, the 383rd Infantry Division was assigned the difficult task of fighting rearguard actions to cover the Bobruisk breakout.265 These rearguards were reported still resisting the pursuing Soviets in the northern outskirts of the city at 1300 hrs. 266 These rearguards were mostly overtaken by pursuing Soviet forces. The rearguards would often have to fight off attacks from all directions. Flexible use of assault guns were required to fight off Soviet armor. Lieutenant Behr of the 383rd Infantry Division coined the alert warning "panzer nach vorn" (tanks to the front) or "panzer nach hinten" (tanks to the rear) to move the assault guns to the point of crisis. 267

Major General Haman, Commandant of Bobruisk and Lt. General Hoffmeister, Commander of the XXXXI Panzer Corps had successfully broken out of Bobruisk during the night, but were later captured during the retreat to the west.268 Nevertheless, a large German force broke out the encirclement at Bobruisk. German aerial reconnaissance reported around $1200 \mathrm{hrs}$ that the front of a large German column was approximately $10 \mathrm{~km}$ northwest of the city. Between this location and Ossipowitschi a Soviet formation was reported moving to the northeast which could possibly cut off the German breakout. The 9th Army requested that all the resources of the German 6th Air Force be employed to assist this breakout.269 According to aerial reconnaissance weak armored spearheads of the XXXXI Panzer Corps and XXXV Army Corps had reached the region east of Ossipowitschi by $1700 \mathrm{hrs}$. The German column was lead by six tanks and ten vehicles with the infantry 
marching in the rear which stretched back to Bobruisk.270 There were also other German forces noted by aerial reconnaissance which were recognized $10-15 \mathrm{~km}$ north of Bobruisk on the east bank of the Berezina River.

A new defensive front further to the west was being assembled with the Lindig force which contained the 390th Field Training Division and the 12th Panzer Division. The new front consisted of the Marina Gorka Bridgehead extending to Talka and Lapitschi which sealed off the Bobruisk-Minsk road. 271

$$
\text { JUNE 30, } 1944
$$

\section{3rd Panzer Army}

The threat to the south flank of the 3rd Panzer Army emerged with the repeated Soviet attempts to cross the Berezina river. A Soviet thrust into the rear at Kalnik increased the threat to the army. The 212th Infantry Division was withdrawn to the southwest first behind the Berezina river and later behind the Ponja river.

During the night Soviet forces pushed through the right flank of the 212th Infantry Division northeast of Begoml and crossed the Berezina river occupying Babzy further to the west. 272 The security forces in Kalnik were withdrawn to the northwest to protect the Ponja river crossing at Juchnowka. 3rd Panzer Army sent Army Group Center a report about strong Soviet columns 
concentrated on the east bank of the Berezina river at Brod and Begoml. Air strikes by the Luftwaffe were requested.

Field Marshal Model wanted to block the Lepel-Dokszyce road and also the rail line from Glebokie to the west. Therefore, 3rd Panzer Army was given command of the 391st Security Division. The division commander, General von Monteton had his command post in Glebokie.273 The Soviets were viewed as moving in two directions. The northern group was moving in the direction DvinaDuenaburg and was already west of Polozk on the Dvina river. The southern group with the 1st Tank Corps was viewed as thrusting south in the direction of Minsk possibly taking Molodetschno. Meanwhile, in the center the Soviet 43rd Army would attack along both sides of Glebokie.

Colonel General Reinhardt advised the Chief of Staff at Army Group Center that the main danger to the 3rd Panzer Army was in the south where the Soviets were crossing the Berezina river at Brod outflanking the Panzer Army. ${ }^{274}$ The crossing site at Kalnik was lost and in order to avoid the 212th Infantry Division from being cut off it became necessary to withdraw the division behind the Ponja river. Reinhardt made it clear with the weak forces at his disposal that they must be deployed behind a river or in a prepared position in order to hold a sector.

The 212th Infantry Division smashed a Soviet attack in battalion strength east of Beresino by concentrated fire. During the evening several Soviet attacks on both sides of the Beresino river crossing in battalion strength were repulsed. Finally, the 
212th Infantry Division received the order to withdraw from the Berezina position at $1730 \mathrm{hrs}$ and begin the defense of the Ponja river sector. However, the Soviets had already crossed the Ponja river on the southern wing of the Panzer Army. Dokszyce was also abandoned in the withdrawal (see Figure 112).275

IX Army Corps. Chief of Staff of the IX Corps reported the withdrawal to the Gorilla line and withdrawal of the left wing of the 212th Infantry Division to Tscherniza. Colonel General Reinhardt informed General Wuthmannn at 1830 hrs that the Soviets had occupied Dzissna and had formed a bridgehead southwest of Dzissna. The IX Corps was ordered to begin its withdrawal movement to the line east of KrolewszczyznaHolubicze-Plissa Lake. The Corps was to focus its effort on protecting the rail junction at Glebokie. Army Group North was . given the task to restore the connection to the 3rd Panzer Army at Glebokie. General Wuthmann informed Colonel General Reinhardt that he could only defend Glebokie from the northeast but not from the north. Reinhardt replied that he did not think the Soviets could get through the swamp, but assault guns would be held in reserve if necessary.

\section{4th Army}

VI Army Corps. The VI Corps was placed under the unified command of Lt. General Vincenz Mueller. All troops south of Tschernjawka would belong to Gruppe General Mueller. The VI Corps Headquarters crossed over the Berezina at Shukowez on a 
temporary bridge. By $1200 \mathrm{hrs}$ the first elements of the VI Corps had crossed over the river.

XXVII Army Corps. It was reported at $1800 \mathrm{hrs}$ that the spearhead of the Corps was west of Krugloje. There was no radio contact with the Corps.276 Gruppe General Mueller which was forming rear guard defenses $30 \mathrm{~km}$ east of the Berezina river finally reported that the XXVII Corps was now west of Krugloje (see Figure 115).

XXXIX Panzer Corps and XII Army Corps. The 4th Army reported to the XXXIX Panzer Corps at $0315 \mathrm{hrs}$ that the road to Beresino was under enemy fire.277 However, the bridge was still in German hands, intact and operational. General Tippelskirch transferred his command post from Shornowka to Ssmilowitschi at 0400.278 However, Tippelskirch remained in Beresino to meet with Lt. General Vincenz Mueller, Commander of the XII Corps.

Tippelskirch had appointed Mueller commander of all troops in the VI Corps, XXXIX Panzer Corps, and the XII Corps for the purpose of expediting the withdrawal over the Berezina river. 279 The XXVII Corps was the only Corps excluded from his command. Tippelskirch in reference to the withdrawal movement advised Mueller to expedite the entire withdrawal movement by disposing of all superfluous material and regardless of heavy vehicles open the Belynitschi-Beresino road.280 Tippelskirch issued the following order:

The sharp reduction in fighting strengths and the need to fight two separate battles within 4th Army's area 
make it essential to combine all troops engaged south of Tschernjawka, including the VI Army Corps Headquarters into a single group.

These troops will therefore be formed into Gruppe General Mueller under the command of General Vincenz Mueller. This order takes effect forthwith.

General Mueller is to see to it that the elements of the XXXIX Panzer Corps Headquarters freed by this reorganization are extricated by the fastest possible means and transferred via Minsk to the Korps Gruppe von Saucken. 281

The rapid movement of the 31 st Infantry Division over the Beresino Bridge was ordered. The 12th Grenadier Regiment was already near the bridge. The XXXIX Panzer Corps reported that the 110th Infantry Division was falling back under strong Soviet pressure and wanted to know which bridge across the Berezina river was available for the division's withdrawal. Currently, General Mueller notified the XXXIX Panzer Corps that as of $1130 \mathrm{hrs}$ traffic over the bridges was not possible.282 In the XII Corps area, the 18th Panzer Grenadier Division and the 267th Infantry Division movement proceeded as planned. The XII Corps had no report from the 57th Infantry Division, but it was noted to have had especially difficult obstacles to overcome in the withdrawal. The XII Corps line secured by rear guards was now the line Ussakino-IglizaKorythiza-south of Pyschatschje (see Figure 115). The XII Corps was approximately $30 \mathrm{~km}$ from from the Berezina river at 2100 hrs. (see Figure 115).283 There were 50 to 60 Soviet tanks reported to have passed through Uchwala advancing to the west. 
The situation on the Beresino bridge was growing more tense by the hour. The Soviets south of the bridge were laying down harassing fire along the bridge and road. The Soviet Air Force conducted continuous, rolling air attacks since 1630 hrs. General Mueller ordered extensive destruction of baggage trains and vehicles to clear the road to Beresino.284 There was a shortage of fuel and food among the retreating troops. The situation west and north of Beresino was growing more precarious (see Figure 115). The 286th Security Division reported that Soviet infantry at Poplawy (9 km southwest of Beresino) had crossed the large road to the north. The bridge at Tschernjawka was burnt and two Soviet tanks which had crossed the bridge were destroyed.285 The Soviets had crossed the Berezina river in several places north of Nowosselki. The town of Beresino had been under heavy air attack since 1700 , but the bridge was still passable.286 General Oschmann, Commander of the 286th Security Division was lightly wounded during the air attacks. The road to Tscherwen at $1855 \mathrm{hrs}$ was again cleared of Soviet forces and opened so the traffic was able to move.

Field Marshal Model's new order for the main mission of the 4th Army was received at $2200 \mathrm{hrs:}$

4th Army's main task remains to get its divisions back behind the Berezina river in as battleworthy a condition as possible while the reinforcement of the echelons on both flanks continues. Contact with 9th Army's eastern flank through Tscherwen is to be established and maintained. The protection of the flanks on the north wing is required and the prevention of the outflanking 
of Borissow in the north. The defense line is to be pulled back to the road behind the the Berezina river on both sides of Borissow. This would free the 5th Panzer Division in case of an emergency to be employed west of the Berezina river to the northwest. There is no available garrison for Borissow. Borissow is to be incorporated into the forming of a defensive front as a strongpoint (see Figure 116). ${ }^{287}$

Field Marshal Model made it clear that he would not be bound to hold Hitler's designated fortresses when he chose not to garrison "Fortress Borissow. 288

The situation reported by the 4th Army at 0250 hrs on July 1, 1944 stated that most of Gruppe General Mueller (XII Corps, remainder of VI Corps, and XXXIX Panzer Corps) was still retreating toward the Berezina river (see Figure 115). ${ }^{289}$ The threat to the Beresino bridge had intensified. The bridge was now under observer directed artillery fire. There was an approximately 60 $\mathrm{km}$ long column of horse-drawn wagons and motorized vehicles two and three abreast on the Belynitschi-Beresino road moving west slowly because of heavy traffic congestion. 290

The Chief of Staff of the 4th Army, Colonel Dethleffsen summarized the plight of the 4th Army:

Lack of information on the flanking armies' situation makes it impossible for the 4th Army to judge whether there is a risk of the enemy developing a third encircling ring with pincers meeting about in the region Minsk. The large gap on 3rd Panzer Army's right leads one to suppose that there is no way of stopping an advance on Minsk by strong enemy forces, especially from the north. The extraordinary degree of enemy air superiority, German troops fighting in the east had not imagined until now, lead to especially high losses on 
our side; combined with his numerical superiority in tanks and the constant threat to our formations flanks and rear which resulted in the dismemberment of a unified front to neighboring armies has resulted not only in a considerable deterioration of combat worth but also a sharp decline in morale. Our losses of weapons are extraordinarily high. The difficult terrain east of the Berezina river through which our formations must traverse as they fight their way back has given rise to irreplaceably high losses of vehicles and precious material. Losses among commanders are terrible. XXXIX Panzer Corps has lost three commanding generals within 24 hours. Only a few formations are still firmly under their commanders' control.

We can only reckon with significant elements of 4th Army being available to be employed in the development of a new defensive front if they are spared the burden of being bottled up again in the area of Minsk. ${ }^{291}$

The end of June 30, 1944 marked the 8th day of the Soviet offensive and sealed the fate of the 4th Army divisions when the Soviets obtained observer directed artillery fire on the Beresino bridge.292 The Beresino-Tscherwen road had also been cut again by Soviet forces. Meanwhile, German forces in their vehicles waited in long columns to cross the Berezina river while the Soviet Air Force conducted continuous attacks against the masses of vehicles in the 4th Army pocket (see Figure 115). The rear guards of Gruppe General Mueller were still $30 \mathrm{~km}$ east of the Berezina river while Soviet motorized and armor formations were outrunning the Germans to the west (see Figure 115). The Soviets were approaching from the south on a broad front along the BeresinoTscherwen road.293 There were still no available forces on the Beresino-Tscherwen-Minsk road. The weakened regiments from the 
31st and 12th Infantry Divisions were speedily brought up so they could be used to hold this road. The Soviets had already crossed the Berezina river southeast and north of Borissow (see Figure 115). They were advancing by swinging wide of Borissow to the west with strong armored formations (see Figure 115).294 These Soviet forces presumably reached an area $20 \mathrm{~km}$ north of Minsk (see Figure 115). The German forces in the 4th Army by contrast were forced to destroy the infrastructure of their Army with the destruction of military material and vehicles east of the Berezina river.

\section{Gruppe von Saucken}

General von Tippelskirch had flown out to brief General von Saucken personally during the morning. Tippelskirch had moved his headquarters to Ssmilowitschi and arrived at $1100 \mathrm{hrs}$ to receive a report that the Soviets had reached the beginning of the Berezina river and were moving in columns on the Lepel-Biehomla road and on the track Ssklez-Postreshze-Brod. Gruppe von Saucken received a reinforced reconnaissance detachment with artillery to reconnoiter the west bank of the Berezina river to the north and determine Soviet strength in the area of Biehomla. This unit was assigned to block any southwestern movement by the Soviets. There was a report at 1000 hrs of 5 Soviet tanks north of Rudnja (18 km west of Borissow) moving south.295 This spearhead was to be repulsed by 10 tanks and a rifle company from the 5th Panzer Division. East of Kamien Soviet armor had penetrated Ziembin and 
a bridgehead was being built north and east of the town. A strong Soviet armor attack occurred $7 \mathrm{~km}$ southeast of Ziembin and the armor broke through. Borissow was now under attack by more than 50 tanks from the north, east and southeast (see Figure 115).296 The Soviets started building bridges at Nowosselki and at Mal. Ucholody which permitted them to secure the west bank of the Berezina river.297 During the evening the Soviets broke through the German Bridgehead at Borissow east of the highway bridge (see Figure 116). ${ }^{298}$ Another Soviet breakthrough to the north at Studenka was sealed off. A Soviet detachment from the Brod area with 5 tanks and artillery appeared at Pleszczenice $(60 \mathrm{~km}$ northwest of Borissow) and was destroyed.

The 4th Army was now faced with encirclement from the north and south (see Figure 115). Furthermore, it had to execute a crossing of the Berezina river without adequate crossing points and under continuous air attack while resisting the pressure of encirclement. The entry made in the war diary for June 30, 1944 described the situation of the 4th Army as almost hopeless. 299

\section{9th Army}

The Soviets were reported advancing beyond "Fortress Sslusk" (see Figure 117) to the north. The 9th Army had prepared strong positions south of Usda. The front southeast of Marina Gorka was holding. Army Group Center ordered the 9th Army to use the 12th Panzer Division to block the Soviet advance southeast of Minsk. Furthermore, the 9th Army was placed in command of 
"Fortress Minsk" and was given the assignment to "increase the defensive readiness of "Fortress Minsk" with all possible means" at 00.00 hrs, June 30, 1944 (see Figure 118). 300

Meanwhile, the 9th Army was struggling to withdraw the remnants of XXXXI Panzer Corps and the XXXV Army Corps from the Bobruisk pocket (see Figure 119). The 20th Panzer Division's armored advance group ran into strong Soviet resistance at Tschutschja and threw the Soviets back. The woods north of Tschutschja were then cleared of Soviets. The German spearhead then encountered renewed Soviet resistance at Oktjabr which was smashed with the capture of the glass factory. 301 The Germans captured various Soviet heavy weapons. Lt. General von Kessel, Commander of the 20th Panzer Division deployed a captured Joseph Stalin tank (see Figure 99) at the end of the German column to secure the rear. The removal of the threat to the right flank facilitated the mass of retreating German columns to advance north between Shatkowo and Ssytschkowo (see Figure 114). The Soviets were next encountered at the road junction northeast of Ssytschkowo attacking the flank of the German column from the north and west. The various Kampfgruppen assembled along the bank road which ran parallel to the Berezina river and fought off various weak Soviet attacks while retreating north (see Figure 114). This column reached the area of Werbki in the afternoon.

Lt. General Hoffmeister reorganized the units from various divisions for a further retreat. The 20th Panzer Division remained the most powerful unit possessing several tanks, 12 half-tracks 
and a self-propelled howitzer. ${ }^{302}$ The 383rd Infantry Division conducting the rearguard action could not always block all the Soviet attacking units and individual Soviet tanks sometimes broke through and would attempt to shoot up the German columns. But once the German columns crossed the bridge at Werbki this problem was prevented by the deployment of $88 \mathrm{~mm}$ Flak guns which secured the bridge from attack by Soviet armor.303 The Germans after concentrating their forces captured Ssloboda, the rail bridge north of Oktjabr and the Sswisslotsch crossing north of Ssloboda. However, Sswisslotsch remained under Soviet control and Soviet reinforcements were pouring into the town.

The most foreward elements of the XXXXI Panzer Corps and the XXXV Army Corps reached the Sswisslotsch estuary as the 12th Panzer Division was advancing toward the Sswisslotsch sector to make contact with 9th Army elements retreating from Bobruisk. The Hoffmeister force reported the following status during the morning: "Bridge at Sswissiotsch in our hands. Short of rations, fuel and ammunition. Where do we go from here?"304 The 12th Panzer Division replied: "Make for Pogoreloje."305 The Hoffmeister group reported at 1355 hrs:

Having to fight hard to break through again today. Sswisslotsch bridge in our hands, Berezina bridge in enemy hands. Short of ammunition, medical supplies and rations. 306

The Hoffmeister force reported later in the afternoon having captured all three bridges around Sswisslotsch: the Sswisslotsch 
river bridge west of the town; the road bridge over the Berezina river into the town; and the railway bridge over the Berezina river to the south. ${ }^{307}$ Unfortunately, the Bobruisk survivors could not hold onto the bridges and they were lost again. ${ }^{308}$

Meanwhile, the 12th Panzer Division continued its attack at Lapichi and threw the Soviets back across the Sswisslotsch river. The 9th Army Commander, General of Armor von Vormann ordered the Lindig force (see Figure 119) at 1510 hrs to launch a relieving attack with the 12th Panzer Division from Pogoreloje toward Sswisslotsch before first light. ${ }^{309}$ The fate of approximately 30,000 men depended on the attack of the 12th Panzer Division toward Sswisslotsch. 310

The Bobruisk survivors regrouped and the ordnance officer of the 36th Infantry Division reconnoitered a route for the breakout of the motorized vehicles. The motorized column would begin moving with the onset of darkness to the west and then turn north to the bridge at Lipen. The objective was to reach Pogoreloje where the advance units of the 12th Panzer Division were located. 311 This column commenced its western movement at $1800 \mathrm{hrs}$ after receiving supplies from the air. Meanwhile, the 383rd Infantry Division secured the town of Tschutschja against a Soviet armor attack at 1930 hrs and later in the evening the SswisslotschBerezina triangle against mounting Soviet pressure. The attempt to secure the right flank by the demolition of the Berezina river bridge north of Oktjabr failed. 
During the evening of June 30th the bridge at Lipen was occupied by the Kampfgruppe Colonel von Lilienhoff. This Kampfgruppe stormed the bridge using a captured T-34 tank (see Figure 120) and successfully broke through. 312 This bridge would later on July 1st provide a crossing for Lt. General von Kessel's Kampfgruppe to reach the 12th Panzer Division.

General Hoffmeister sent part of the armored group of the 20th Panzer Division in the southwest direction toward Brizalowitschi to secure the left flank and then turn north to reach Lipen-Malinowka. The flank security was necessary due to a reported Soviet column moving from Ossipowitschi in the direction of Sswissiotsch. The armored group as expected met the Soviets at Brizalowitschi and the 59th Panzer Grenadier Regiment launched an energetic attack which repulsed the Soviets. However, most of the half-tracks were lost because of Soviet tank fire. It was during the night that the half-track containing Generals Hoffmeister, Engel and Conrady was lost and the generals were reported missing. ${ }^{313}$ It was later discovered that all three generals had been taken prisoner by the Soviets. ${ }^{314}$

Field Marshal Model in discussion with $\mathrm{OKH}$ outlined his reinforcement needs. The 4th Panzer Division and 28th Jaeger Division were to assemble in the Baranovichi-Ssluzk area. The 1st Hungarian Cavalry Division from the 2nd Army was also to reinforce Baranovichi. The 170th and 132nd Infantry Divisions were to reinforce the Minsk area. The 170th Infantry Division was to be committed at Molodeczno. The 7th Panzer Division was to be 
employed at Baranovichi or Molodeczno depending on the situation. Minsk was not be held as a "Fortress." Therefore, Army Group Center was anticipating at least five new divisions to build a new defensive line on the Baranovichi-Dzerhinsk-Molodeczno axis. These five divisions were: 4th Panzer Division, 7th Panzer Division, 28th Jaeger Division, 132nd Infantry Division, and 170th Infantry Division. 315

$$
\text { JULY 1, } 1944
$$

\section{3rd Panzer Army}

The main danger to the 3rd Panzer Army remained the hole between it and the 16th Army of Army Group North. ${ }^{316}$ The probable Soviet advance in the direction of Duenaburg would require them to take the area around Glebokie. This would result in the severing of the 3rd Panzer Army's lifeline since south of the road and rail line Glebokie-Postawy and west of it lay partisan infested terrain containing well lead partisan units totaling at least 12,000 men (see Figure 121). ${ }^{317}$ Nevertheless, the forces to close the hole between the 16th Army and 3rd Panzer Army were not available. The 3rd Panzer Army was also threatened in the south by Soviet forces that were moving through the ever enlarging hole between the 3rd Panzer Army and the 4th Army in the south (see Figure 122). ${ }^{318}$ This hole in the south like the hole in the north could only be closed by the deployment of new forces. 
During the afternoon Soviet forces in battalion strength moved from the northeast out of the swamp and emerged at Torgany in the rear of the 212th Infantry Division. This development caused the division to issue the order for withdrawal at $1600 \mathrm{hrs}$. The division had already been weakened by reinforcing the area of Glebokie. Glebokie remained the key position on the entire front. The 212th Infantry Division dispatched the Grenadier Regiment 423 and a battery of assault guns from Assault Gun Battalion 232 toward Glebokie.

The IX Corps reported that Soviet reconnaissance forces were at Werecieje. Colonel Praefke, Chief of Staff of the IX Corps advised Major General Heidkaempfer that the Soviets were trying to outflank the corps on the left flank. Heidkaempfer advised the IX Corps that they must hold their present position so the withdrawal of the 212th Infantry Division could be executed along both of the single roads leading from Glebokie to the west (see Figure 121). ${ }^{319}$ The only other retreat route was through partisan infested terrain southwest of Glebokie, but this route would only be used in an extreme emergency. The Grenadier Regiment 423 was to deploy north of Glebokie with the assault guns. The commander of the assault gun battery reported, however, at $1600 \mathrm{hrs}$ that the Soviets had reached the wooded terrain south of Miereckie. The Soviets from this location had begun to fire their artillery on Glebokie.

General Wuthmann requested to withdraw the IX Corps under cover of darkness, but Colonel General Reinhardt instead demanded 
a counterattack tomorrow toward the north with all available forces concentrated for the attack. The release of the following reserves for the attack was granted: Engineer Battalion 62, Grenadier Regiment 423, and assault guns.

The 252nd Infantry Division after it pushed back the Soviets advancing on Glebokie was to be pulled back to the area of the west edge of Plissa Lake to Ginki. The 252nd Infantry Division and Corps Detachment D had lost contact with each other because the Soviets managed to occupy the woods between the two divisions.

The IX Corps Command Post was now located at Gut Konstantinowo, $12 \mathrm{~km}$ southwest of Glebokie (see Figure 121). 320 The Soviets were clearly interested in seizing Glebokie since this would serve as the key road and rail junction for further operations against Duenaburg. It was clear that the next Soviet operations would be to take Glebokie thereby severing the road and rail lifeline to the 3rd Panzer Army. Consequently, the 212th Infantry Division received the order at $2100 \mathrm{hrs}$ to withdraw and defend the position between Serwetsch (west of Parafjanowo)-north of Dokszyce-west edge of the swamp terrain northeast of Dokszyce. The 3rd Panzer Army Headquarters was transferred during the course of the day to Postawy (see Figure 121). ${ }^{321}$

\section{4th Army}

The 4th Army Headquarters in Ssmilowitschi had received few reports during the night. The XXXIX Panzer Corps reported that the Panzer Grenadier Division "Feldherrnhalle" was located on both 
sides of the main highway behind the Klewa river (see Figure 122). The 110th Infantry Division was still the furthest division to the east (see Figure 122).322 A Soviet attempt at encirclement was prevented by the destruction of the Mosha Bridges. The corps wanted-to build a bridgehead east of the Berezina river with the 110th Infantry Division in the line Shurowka-DmitrowitschiOreschkowitschi. The 110th Infantry Division was directed to head for Shukowez.

General von Tippelskirch flew to Beresino in the early morning. He discovered that Gruppe Floerke was withdrawing from their position at Tschernjawka. Tippelskirch viewed this action as premature. He wrote down an order to Lt. General Floerke personally:

The decision now to withdraw to the south is intolerable given the scope of the total situation of the army. You are to turn around immediately and attack the enemy moving through Murowo. A withdrawal is only permitted under heavy enemy pressure and is only allowed up to the Usha which must be held and connection with the VI Army Corps at Shukowez established...It is critical therefore that this order is strictly carried out. ${ }^{323}$

Minsk was now threatened by Soviet mobile forces. The 170th Infantry Division was enroute by train to Minsk but its arrival was not anticipated before July 2 nd at $0600 \mathrm{hrs}$. Between Minsk and Molodeczno the 221st Security Division was deployed to secure the rail line. The Commandant of "Fortress Minsk," General Sperling had only 900 men from alarm units and stragglers that had 
been picked up. 324 Soviet attacks were anticipated to be coming soon.

Gruppe von Saucken whose main task remained the securing of the the Borissow-Minsk road also prevented Soviet traffic from crossing the road to the south and penetrating the region north of Lohojsk (see Figure 122). In Beresino from 0400-0430 hrs the sound of combat could be heard from the direction of Pogost. In Brodez (15 km south of Beresino) a Soviet division was assembling to cross the Berezina river. ${ }^{325}$ The Soviets had already advanced to Negonitschi west of the Berezina river around midnight with an entire division.

Kampfgruppe General Mueller had several objectives to accomplish today. It had to destroy the weak Soviet forces that were east of the Berezina river blocking the German retreat and then immediately cross over the river and shore up the south flank of the Berezina river. ${ }^{326}$

The 4th Army presented Army Group Center at $1000 \mathrm{hrs}$ with a summary of its situation. The 267th Infantry Division and 18th Panzer Grenadier had smashed the pursuing Soviet forces in the area south of Igliza. Northwest of Brodez the Soviets had crossed the Berezina river in division strength and were advancing to the north. The Panzer Grenadier Division "Feldherrnhalle," and the 110th Infantry Division were west of the Klewa river on both sides of the Minsk-Smolensk highway. Tschernjawka was taken by the Soviets. ${ }^{327}$ Kampfgruppe vọn Saucken after a hard battle lost Borissow (see figure 123). ${ }^{328}$ The forward line of the Kampfgruppe 
currently runs from $6 \mathrm{~km}$ southwest of Gliwin to Rudnja on the Ussjasha river (30 km northeast of Minsk) (see Figure 123).

The XXXIX Panzer Corps reported that the Soviets with strong forces and armor had pierced the position of the Panzer Grenadier Division "Feldherrnhalle" north of the Minsk-Smolensk highway at Kotytniza and was pressing the attack further in the direction of Galez. Soviet armor was also reported to have broken through the line of the "Feldherrnhalle" at Kukarewo. The Soviets had also reached the Berezina river northeast and west of Shurowka. 329 The XII Army Corps requested an air attack from the IV Flieger Division against the Soviets east of Korytniza and to the south on the road. The XII Corps reported at $1108 \mathrm{hrs}$ its intentions to build a bridgehead at Beresino to bring across units to the west bank of the Berezina river and hold open the crossing to the west. Fighter cover was necessary the entire day. The destruction of Soviet forces at Selischtsche was not possible due to the shortage of forces. But here and on both sides of Shornowka German countermeasures were underway.

The XII Army Corps reported at $1300 \mathrm{hrs}$ that the 267th Infantry Division and 18th Panzer Grenadier Division were now in the line Dulebo-Matschesk-Babinka and had received orders to retreat to the Klewa river. Dulebo was under heavy attack. The Panzer Grenadier Division "Feldherrnhalle" was now in the line Babinka-Sababiny-Galez. The 57th Infantry Division was advancing out of the area west of Golynka, the 110th Infantry Division was engaged in the withdrawal to the bridgehead Shukowet. The 31st 
Infantry Division has reached the Klewa river. The Soviet concentration at Sselischtsche (5 km north of Beresino) was reported on the Berezina river. 330

Kampfgruppe Mueller was presently in danger east and west of the Berezina river. Soviet armor with infantry was reported at $1115 \mathrm{hrs}$ to have pushed through Tscherwen to the north and cut both sides of the Minsk-Smolensk highway thereby cutting off the route of retreat and supply for the 4th Army (see Figures 122 \& 123). 331 The 286th Security Division and the XII Army Corps were ordered to immediately send combat effective units with anti-tank (Pak) guns to clear out the Soviet forces severing the 4th Army's lifeline to the west. ${ }^{332}$ 4th Army reported at $1355 \mathrm{hrs}$ to Army Group Center that ground supply was no longer possible, and that air supply of food, fuel and ammunition was necessary for the units at Beresino and all units east of Tscherwen. ${ }^{333}$

The 110th Infantry Division was ordered at $1505 \mathrm{hrs}$ to immediately march through Mikulitschi on Tscherwen. However, the 110th Infantry Division reported that the situation on the west bank of the Berezina river and on both sides of the Shukowez bridge could only be controlled by bringing up new forces from the west since the XII Corps had no further available forces.

The next few hours brought more adverse reports. Kampfgruppe Koenig reported at $1120 \mathrm{hrs}$ that Soviet forces of unknown strength had blocked the road at Now. Marjanowka and Kampfgruppe Koenig was incapable of freeing the road.

Kampfgruppe Floerke reported at $1715 \mathrm{hrs}$ that the Soviets had 
taken Nowosselki. The 110 th Infantry Division reported that contact was made in Schepelewitschi with the 25th Panzer Grenadier Division which was now $50 \mathrm{~km}$ from Beresino. The Soviets which had broken through the Panzer Grenadier Division "Feldherrnhalle" on the Minsk-Smolensk highway were at $1700 \mathrm{hrs}$ $1 \mathrm{~km}$ from Pogost. 334

The 4th Army sent a summary of the situation to Army Group Center and $\mathrm{OKH}$ at $1815 \mathrm{hrs}$ stating:

The enemy through the advance of strong forces west of the Berezina river from the south and through the extension of his breakthrough position on the Berezina at Tschernjawka has encircled the XII Army Corps and the XXXIX Panzer Corps. Consequently, the failure to respond with air supply en masse for these corps and the XXVII Army Corps will result in the breakout of units which will cease to be combat effective. The advancing enemy armor forces from the northeast on Molodeczno precluded the rail transport of approaching reinforcements for Minsk. The Army at the moment only has freedom of action for the 5th Panzer Division and its mission to secure the unloading of approaching reinforcements in the region of Molodeczno and from there to restore contact with the 9th Army in the direction of Stolpce. The enemy advance on Minsk will be delayed as long as possible. A General Staff Officer from the Army Group with full command authority is requested for Minsk early on July 2nd. ${ }^{335}$

The 4th Army transferred their Command Post to the encampment at Melitta on the highway $6 \mathrm{~km}$ east of Minsk. ${ }^{336}$

Kampfgruppe von Saucken reported that the Soviets were advancing on a broad front on both sides Kamien (12 km northwest of Ziembin) against the line Kozyry-Chotajewicze. The Soviets 
advancing through Pleschtschenije to the southwest made it necessary for a rapid concentration of forces in the Kaina sector northwest of Lohojsk. General von Saucken ordered the withdrawal of the front to the highway sector on both sides of Smolewitschi which would shorten the front.

The 286th Security Division was ordered to send a Kampfgruppe to the area east of Tscherwen to combat the Soviet units that had broken through in this area. Lt. General Mueller had restored communications with Lt. General Graf von Oriola who was presently the commander of VI Army Corps and Lt. General Floerke of the 14th Infantry Division. 337 He requested that sufficient forces with anti-tank weapons be transferred toward Tscherwen (see Figure 123). Soviets were attacking Poplawy at 1800 hrs. A Soviet force of 200 men was reported to have crossed the Berezina river at Sharnowka.

The 4th Army issued the last report of July 1, 1944 stating:

Fighting heroically on all sides in places against a closely pursuing enemy with superior forces, the army's last divisions are trying to fight their way back to the Berezina river despite shortages of ammunition, rations and fuel. 338

The 57th Infantry Division was attacking in the area west of Golnyka. The 267th Infantry Division, 18th Panzer Grenadier Division, and Panzer Grenadier Division "Feldherrnhalle" earlier were fighting between Dulebo and Galez. Presently, these divisions were trying to fight their way back to the bridgehead south of the Minsk-Smolensk highway between Beresino and Pogost. ${ }^{339}$ The 
Soviets were reported to have broken through the German lines north of Pogost. In the rear of the 4th Army, the Soviets had crossed the river at Guta (6 km southwest of Beresino) and had reached the road at Sslobodka and Tscherwen west of the river. 340 Further north the Soviets had taken Nowosselki and crossed the Berezina river in numerous places. The 110th Infantry Division had reached Shukowez on the Berezina river, but had completely exhausted its rations. ${ }^{341}$ The Kampfgruppe von Saucken was engaged in heavy battles west of Borissow against superior Soviet forces. There was also no communication with the XXVII Army Corps. ${ }^{342}$

General von Tippelskirch sensing the desperation of the 4th Army felt that he should fly personally to the cut off corps because as Commander of the 4th Army he belonged with his troops. ${ }^{343}$ However, Colonel Dethleffsen, Chief of Staff of Army Group Center argued that this was not the time "to make a gesture" but to build a new front from the rear.344 Tippelskirch in the end agreed with Colonel Dethleffsen.

The 4th Army situation was desperate. The 4th Army reported that the XII Army Corps, XXXIX Panzer Corps and the XXVII Army Corps were encircled (see Figure 122). ${ }^{345}$ On the right flank the Soviets had occupied the only road that the 4th Army could use as a route of retreat. The Soviets were also occupying a wide front east of Tscherwen. On the left flank the Soviets had reached the Berezina river at Shornowka and Shukowez. The Soviets had also crossed the river between Tschernjawka and Borissow. Borissow 
was captured by the Soviets. Kampfgruppe von Saucken was locked in battle west of Borissow and Soviet armored forces were approaching Molodeczno (see Figure 122). The mass of the 4th Army still remained east of the Berezina river. Kampfgruppe Mueller was being thrown back into a bridgehead east of the Berezina river and the XXVII Army Corps still remained $50 \mathrm{~km}$ to the northeast of the river. Lt. General Mueller reported at $1900 \mathrm{hrs}$ Soviet breakthroughs with armor at Dulebo and on the highway toward Pogost. The Berezina bridgehead had been contracted to a depth of $6-10 \mathrm{~km}$ as a result of ammunition shortages for artillery and heavy weapons.346 Elements of the 31 st Infantry Division, 267th Infantry Division and 286th Security Division were transferred to the west bank of the Berezina river to prevent the Soviets from bypassing them and reaching their rear area. Lt. General Mueller requested continuous fighter cover and Luftwaffe air strikes for July 2nd against the Soviets on the highway northeast of Pogost. The failure of the air supply effort in providing sufficient quantity of supplies meant that the breakout of the corps would result in the loss of combat effective units. ${ }^{347}$

The 4th Army reported the following order of battle during the evening of July 1, 1944:

Kampfgruppe Mueller:

XII Army Corps with elements of 31st Infantry Division; remnants of Panzer Grenadier Division "Feldherrnhalle," 12th Infantry Division, 337th Infantry Division; Commandant of Beresino Garrison; 286th Security Division; and the XXXIX Panzer Corps Headquarters. 
Kampfgruppe von Saucken:

5th Panzer Division; Headquarters of von Gottberg force; and Kampfgruppe Floerke (remnants of 14th Infantry Division).

XXVII Army Corps:

110th Infantry Division

Kampfgruppe Koenig:

remnants of Grenadier Regiment 12 (31st Infantry Division); remnants of Grenadier Regiment 27 (12th Infantry Division); elements of the 337th Infantry Division. 348

\section{9th Army}

Lt. General von Kessel crossed the rail line OssipowitschiBrizalowitschi-Ssloboda early in the morning. His group reached the wooded swamp terrain southeast of Lipen. The Bobruisk troops had marched through the night of June 30-July 1st around Sswisslotsch to the southeast of Lipen with the 20th Panzer Division leading the way. ${ }^{349}$ The 20th Panzer Division located the bridge over the Sswisslotsch river at Lipen which was unoccupied by Soviet troops permitting the Germans to cross over the river and proceed in the direction of Malinowka-Pogoreloje.350 Lt. General von Kessel and the commander of Grenadier Regiment 59 along with the remaining staff were leading the column with a half-track in front and a captured Joseph Stalin tank bringing up the rear. The column at $0700 \mathrm{hrs}$ heard the noise of armored vehicles approaching from the direction of Malinowka-Pogoreloje. 
The 12th Panzer Division launched its attack to rescue the survivors of Bobruisk in the early morning hours. Captain Blancbois, Commander of the 1st battalion, Panzer Grenadier Regiment 25 of the 12th Panzer Division reinforced with armor launched his attack at $0210 \mathrm{hrs}$ through Pogoreloje towards the town of Sswisslotsch. 351 The Hoffmeister group reported at 0500 hrs that it held a $3 \mathrm{~km}$ front south of the Sswisslotsch river and that the the town of Sswisslotsch was still occupied by Soviet troops. German tanks of the 12th Panzer Division penetrated as far as Prudichi (2 km northwest of Sswisslotsch) at $0840 \mathrm{hrs} .352$ The Panzer Grenadier battalion during the afternoon had penetrated to within a few kilometers of the Bobruisk force. Captain Blancbois and his Panzer Grenadier battalion mounted in half-tracks fought elements of 4 Soviet rifle divisions before making first contact with the Bobruisk troops in the early afternoon at Malinowka. ${ }^{353}$ This undertaking had assisted the breakout of thousands of 9th Army troops. Later, on July 3, 1944, the 9th Army reported that a total of 25,000 men from Bobruisk had successfully escaped Soviet encirclement. 354

$$
\text { JULY 2, } 1944
$$

\section{3rd Panzer Army}

The 3rd Panzer Army had become increasingly detached from the rest of Army Group Center. Its front was further north closer to Army Group North while a huge hole in the entire front existed in 
the south (see Figure 124). The 3rd Panzer Army concentrated its forces around Glebokie while the Soviets attacked its flanks. ${ }^{355}$ The Soviets using armor had forced their way into Holubicize in the Corps Detachment $D$ sector. The 212th Infantry Division defended the line Parafjanowo-north of Dokszyce-Krolewszczyzna. An attack in regimental strength on both sides of Dokszyce was smashed. Colonel General Reinhardt advised the commander of the 212th Infantry Division at $1035 \mathrm{hrs}$ that the Soviet tank supported attacks would have to be repulsed without further use of assault guns since it was the desire of the IX Corps to have all the assault guns sent to Glebokie. General Senzfuss was of the opinion that the Soviets would not succeed in cutting off the 212th Infantry Division. The division still had security troops available for reserves.

The IX Corps reported at $1050 \mathrm{hrs}$ that Soviet reconnaissance forces had been observed at Laskie $(10 \mathrm{~km}$ northeast of Woropajewo). The Corps dispatched 21/2 flak batteries, 1 assault gun battery and one battalion of infantry loaded in trucks from the 102nd Regiment of the 252nd Infantry Division. The Soviet presence in the area of Laskie represented a serious threat of a wide outflanking movement from the north which threatened the new withdrawal route. Colonel General Reinhardt continued to stress to General Wuthmann of IX Corps the importance of holding Glebokie so that the 212th Infantry Division would have a clear retreat route (see Figure 125). Colonel Schmid reported at 1330 hrs that the village of Osinogrodek was already occupied by the 
Soviets and along the road to the west several burned out vehicles were observed as a result of the surprise attack of the Soviet 44th Motorized Rifle Brigade against Postawy (see Figure 125). The situation had become critical in the south and the north as the front was bent back around Glebokie in a wide arc (see Figure 125). The 212th Infantry Division was placed under command of the IX Corps. 356 The division was to withdraw to the north and then turn west. The 212th Infantry Division was to occupy the line Servecz lake-northwest of Krolewsczyzna-Zabinka. The IX Corps was to maintain contact with the left wing of the 212th Infantry Division holding the line Zabinka-north of Bursy lake at Romanoczuki. This line was to be held and only a withdrawal to the line of lakes north of Glebokie was permitted under severe Soviet pressure.

During the afternoon the Soviets broke into Korolewoon on the right wing of Corps Detachment $D$ with infantry and armor. The Soviets continued to press their attack and took Podhaje. The order was issued to withdraw at $1650 \mathrm{hrs}$ to the 212th Infantry Division and the IX Corps to withdraw in the general line Servecz lake-west bank of lake west of Lastowiec-Pistrowskije lake. Colonel General Reinhardt spoke to General Wuthmann, Commander of IX Corps around $2000 \mathrm{hrs}$ and reported that the 252nd Infantry Division had reached the line on the Pietrowskije lake. The corps was given the mission to hold the position Ssewecz lake-Glebokie and to place its reserves on the supply road. Colonel General Reinhardt now viewed the threat from the south as far greater then the north. The Soviets had turned toward Duenaburg in the north. 
The 212th Infantry Division reported at $2015 \mathrm{hrs}$ that the withdrawal road at Soroki was blocked by the Soviets. Three assault guns were sent to Soroki to assist the withdrawal of the division. The new IX Corps Command Post was located at Ozuny. Colonel General Zeitzler spoke with the Chief of Staff of the 16th Army of Army Group North shortly after $2300 \mathrm{hrs}$. The 16th Army was given the order to hold Polozk as a "Fortress" (Fester Platz). 357 This assignment made a continuous front connecting the 16th Army to the 3rd Panzer Army no longer possible.358 Therefore, the 3rd Panzer Army was faced with a completely open north flank. Colonel General Zeitzler also informed Lt. General Krebs, Chief of Staff Army Group Center around Midnight that the Soviets were on the highway and rail line north of Dunilowicze based on POW interrogation and were preparing to take Postawy.

\section{4th Army}

Lt. General Mueller requested at 0255 hrs air resupply for the 110th Infantry Division on the east bank of the Berezina river opposite Shukowez. Unfortunately, Shukowez had been occupied by the Soviets earlier. This meant that the destruction of the 110th Infantry Division was fairly certain.

During the night the 4th Army Headquarters at Melitta (east of Minsk) was informed by Army Group Center that forces were being channeled to Molodeczno because of the, threat of encirclement from the north. The 170th Infantry Division arriving as reinforcement was ordered to Molodeczno instead of Minsk. The 
Assault Gun Battalion 1337 was also unloaded at Molodeczno. Army Group Center ordered Lt. General Lendle of the 221st Security Division to take command of all arriving elements of the 170th Infantry Division pending the arrival of the commanding officers for this division. The 170th Infantry Divisional elements, Assault Gun Battalion 1337 and Police Regiment 2 were formed into Kampfgruppe Lendle to block the area of Radoskowicze and to hold open the area of Molodeczno.

However, General von Tippelskirch was not comfortable with an unknown general defending his northern flank. Therefore, he ordered Lt. General Metz, a battle proven commander to assume command of the arriving elements of the 170th Infantry Division and the 221st Security Division Headquarters. Metz was ordered to form Kampfgruppe Metz with all available troops in the area. 359 Metz was also given the mission to block the rail line and road to Wilna, and prevent the Soviet motorized troops from advancing to the west by the line Lepel-Borissow.

Lt. General Vincenz Mueller during the late evening of July 1, 1944 had transferred his command post over the Berezina river to an area $6 \mathrm{~km}$ southwest of Beresino and north of the highway. 360 Lt. General Mueller placed the Commander of the 110th Infantry Division in charge of crossing all divisions over the bridge at Shukowez.

Lt. General Krebs and General von Tippelskirch conferred at $0915 \mathrm{hrs}$. Tippelskirch expressed the concern that countermeasures must be taken since the Soviets had almost 
reached the Wilna area. Kampfgruppe von Saucken could not remain west of Borissow when the Soviets had advanced through Wilejka to Smorgonie (see Figure 124). Lt. General Krebs agreed with Tippelskirch. Therefore, General Tippelskirch based upon this understanding ordered Kampfgruppe von Saucken which consisted of the 5th Panzer Division, Heavy Tank Battalion 505 and a multiple rocket launcher battalion to disengage from the current action and advance through Radoszkowice to reach the battle around Molodeczno. The Kampfgruppe was ordered to hold open the swampy terrain section of Molodeczno to permit the unloading of reserves from the west and maintain a base to receive the encircled elements of the 4th Army (see Figure 124).

Kampfgruppen von Gottberg, Mueller, Floerke and the Heavy Tank Battalion 501 were to prevent the Soviet advance and capture of Minsk. ${ }^{361}$ They were also to maintain the connection to the encircled units. Kampfgruppe Floerke was to hold the area around Tscherwen as long as possible because only here did a possibility exist to restore a connection to the encircled formations. $362 \mathrm{Lt}$. General Floerke reported Soviet offensive preparations and requested a Stuka attack on Ostrowy.

The 4th Army Headquarters during the late afternoon established a new command post at Zaslaw $(20 \mathrm{~km}$ northwest of Minsk). ${ }^{363}$ A series of reports were received from Lt. General Floerke at $2105 \mathrm{hrs}$. Floerke had radioed earlier at $1130 \mathrm{hrs}$ that overwhelming Soviet forces had broken through at Lyssaja Gora and his Kampfgruppe had been forced to occupy a new defensive line 
along the Gat river. The German line was reported at $1850 \mathrm{hrs}$ to run through Kukolewka-Tschernogradje. Then at 1955 hrs Floerke radioed that Soviet armor had broken through the center of the position on the road and had turned the flank of the position. The Kampfgruppe proposed to establish a new line at Sadoroshje (on the highway)-Jagodka. The bridge at Ssmilowitschi had been destroyed by aerial bombs and high explosives. The 4th Army ordered Lt. General Floerke to reinforce the units escaping from the encirclement at Ssmilowitschi and prepare to smash the expected Soviet attack. These units at Ssmilowitschi were to be supplied and then immediately evacuated to the west.

General Metz arrived at Molodeczno at $0530 \mathrm{hrs}$ and placed the following units under his command: 170th Infantry Division, Kampfgruppen of the 14th and 299th Infantry Divisions, Police Battalion 31, and the 221st Security Division Headquarters with attached units. Soviet armor emerged in Krasne only $16 \mathrm{~km}$ southeast of Molodeczno. Together the Kampfgruppe 299th Infantry Division and German Tiger tanks pushed the Soviets back. General Metz reported that Wilejka was under weak tank and artillery fire since noon. Metz reported his defensive line north of Molodeczno. A defense screen was being rapidly organized at Smorgonie by Army Group Center. The 5th Panzer Division assembled in the area of Ossoschizkij-Gorodok and freed the rail line to Molodeczno at Krasne (see Figure 124).

In the south Kampfgruppe Floerke was pressed back which decreased the prospects for the encircled corps. Ssmilowitschi 
was picked by the 4th Army as the supply center for fuel, food and ammunition for the encircled corps: XII Army Corps, XXXIX Panzer Corps and XXVII Army Corps. ${ }^{364}$ However, the 4th Army reported at 1940 hrs that ground supply could no longer be guaranteed at Ssmilowitschi and air supply was urgently requested.

Lt. General Vincenz Mueller reported that since early morning a battle continues at Pogost. Soviet crossing attempts north of the Beresino bridgehead had been smashed, the holding of the bridgehead till evening appeared questionable. The Soviets were halted at the Berezina river on both sides of Beresino by the 4th Army (see Figure 126). But the increased Soviet pressure and the outflanking movement in the south made it necessary for the corps and the 110th Infantry Division to withdraw in the direction of Smolewitschi (36 km northeast of Minsk) on the following day. Lt. General Mueller reported at 1845 hrs that his divisions had crossed the Berezina river except for the rear guards.365 Mueller stated that the divisions had "complete confidence" and the "will to breakthrough" in taking the direction toward Smolewicze.366

The 4th Army reported at $2140 \mathrm{hrs}$ that Minsk was threatened from the northeast by Soviet armor (see Figure 126). 367 Kampfgruppe Mueller was informed that it must withdraw through Ssmilowitschi where resupply was planned and then proceed past Minsk to the south then west. The XII Army Corps radioed that it was moving in the direction of Minsk with "complete confidence" and the "will to breakthrough" but help was needed through air 
supply. 368 The 4th Army's supply problems were enormous. More than 20,000 men were starving. ${ }^{369}$ General von Tippelskirch sent the following message to Kampfgruppe General Mueller:

The progress of the corps is followed with a fervent heart. We are doing everything to help that we can with our limited forces. 370

General von Tippelskirch had made a decision for the building of a new front with the withdrawal of the reinforced 5th Panzer Division to the area of Molodeczno (see Figure 124). Kampfgruppe von Saucken remained in the area west of Borissow (see Figure 124). And the remaining German soldiers could not effectively prevent the Soviet armored formations from advancing which had already reached Wilejka and Stolpce. The withdrawal of the 5th Panzer Division, however, opened up the area west of Borissow which lead to the compression of the encircling ring around the encircled corps (see Figure 126).371 Kampfgruppe von Gottberg continued to hold its position on both sides of the rail line in the region of Smolewitschi. General von Tippelskirch prevailed upon both General von Gottberg and Floerke personally to hold their positions east of Ssmilowitschi and Minsk. Kampfgruppe Floerke especially was needed to hold its position while there was a chance to save elements of the encircled corps. But during the course of the day Kampfgruppe Floerke was pushed back from the area west of Tscherwen to Ssmilowitschi. 372 


\section{9th Army}

During the early morning hours of July 2, 1944 Stolpce was still under German control. The 9th Army Headquarters crossed the Njeman and deployed in the town of Mir. ${ }^{373}$ The Soviets were moving rapidly and Soviet armor arrived in front of Stolpce and began firing into the city. The Soviets took the city during the morning and blocked the Njemen bridges that were needed by Kampfgruppe Lindig which was still in the area southwest of Marina Gorka. The 12th Panzer Division received the order to attack the Soviets in Stolpce and throw them back across the Njemen river (see Figure 124).374 The main supply line to Minsk ran through Stolpce which was now cut. The 12th Panzer Division disengaged from the line Talka-Ugolez and Kampfgruppe Lindig to attack Stolpce (see Figure 124).

The 9th Army reported that as of July 2nd 15,000 men from Bobruisk had successfully broken through to German lines with the help of Kampfgruppe Lindig and the 12th Panzer Division. 375 Meanwhile, the Soviets had appeared southeast of Stolpce and to the northwest of Stolpce lay the partisan infested Naliboki woods and swamp area that no longer had intact bridges over the Njemen river. The advance of the Soviets on Molodeczno from the northeast signaled the beginning of the expected encirclement of Minsk (see Figure 126). The Minsk encirclement had approximately a $60 \mathrm{~km}$ circumference.376 The 9th Army Headquarters was forced to move by Soviet pressure from Mir to Nowamysz near Baranowicze. ${ }^{377}$ 
The Soviets advanced from Stolpce to the west and captured Mir with armor and infantry.

$$
\text { JULY 3, } 1944
$$

\section{3rd Panzer Army}

The Soviets during the night had achieved deep breakthroughs southeast and east of Glebokie with strong armor and infantry forces (see Figure 125). The 212th Infantry Division was forced to withdraw to a new position west of Glebokie (see Figure 125). This withdrawal was covered by the heroic actions of weak rear guard troops. The withdrawal was conducted as plannned. 3rd Panzer Army continued to withdraw to the west to avoid envelopment.

During the night the Soviets had achieved deep breakthroughs on both inner flanks of Corps Detachment $D$ and the 252nd Infantry Division (see Figure 125). The IX Corps gave its divisions the order at $0530 \mathrm{hrs}$ to fight their way back to a line west of Glebokie:

Sserwetsch lake-Olchowiki-Gut Konstantynowo-Mosarz. ${ }^{378}$ Contact with the 212th Infantry Division had been lost during the night. The commander of Grenadier Regiment 423 in Dunilowicze reported that the Soviets had broken through west of Glebokie using 2 assault guns and by concentrating its regiments. Grenadier Regiment 423 before the Soviet attack had 400 men and at 1000 hrs only 100 men remained. ${ }^{379}$ The four battalions of the 212th Infantry Division were personally lead from the front during the 
withdrawal by the division commander and the operations officer. The divisional artillery was withdrawn behind a protective screen of infantry.

The IX Corps reported that the Soviets had been deflected from the southern road by the 252 nd Infantry Division. The main Soviet pressure was not in front of Glebokie but from the north. Nevertheless, Colonel Schmied at Zuberki had established an assault gun barrier and prevented a Soviet thrust onto the main road. The intention of the IX Corps was to transfer the 212th Infantry Division to the southern sector and the 252nd Infantry Division to the northern sector of a new defensive line. Corps Detachment $D$ was to disengage and be transferred by motorized column to the lake sector of Postawy. The IX Corps Headquarters remained at Oschany (see Figure 125).

Colonel General Reinhardt informed Lt. General Krebs, Chief of Staff of Army Group Center at $1300 \mathrm{hrs}$ that his troops had lost much of their combat effectiveness. They were fighting their way back to the Dunilowicze line (see Figure 125). A defense of Postawy could not be guaranteed. The right and left flanks of the Panzer Army were just hanging in the air completely open (see Figure 126).380 An immediate reconnaissance was requested especially between both Army Group Center and Army Group North to ascertain the furthest advance of the Soviets. Reinhardt further explained that if the Soviets broke through the Postawy position the Panzer Army would not be able to do anything because of the lack of combat troops (see Figure 125). ${ }^{381}$ 
The rear guards of the IX Corps consisted of blocking positions on the southern road at Laskie and on the northern road at Zuberki. Both blocking positions were occupied by Infantry and assault guns. The Zuberki position repulsed a company strength attack supported by armor at $1330 \mathrm{hrs}$. The IX Corps had been in continuous battle since June 22, 1944 and the troops were exhausted and many were fighting rear guard actions and retreating in their bare feet. 382 The withdrawal to the Holbie sector with the bridgehead Dunilowicze had not been completed by the evening. The Soviets managed to occupy the area on both sides of Postawy. During the evening aerial reconnaissance reported a Soviet armored thrust by 18 tanks from the northeast toward Postawy. The 252nd Infantry Division had its armor protective screen organized on the north edge of the town. The entire IX Corps later in the evening was ordered to withdraw further to the west and occupy the First World War positions west of Postawy on both sides of the town (see Figure 127). ${ }^{383}$ The right wing of the corps was to rest on the northern tip of the Narocz lake and the left wing on the Kamja bend at Vileitos.

Soviet attacks supported by armor and tactical aircraft against Glebokie failed. The 16th Army reported that it would restore contact with the 3rd Panzer Army through Duenaburg. Two divisions were freed by a withdrawal of the I Army Corps and were to assemble southeast of Duenaburg. 
4th Army

On the morning of July 3,1944 , the 4th Army Headquarters in Zaslaw (northwest of Minsk) received two messages from Kampfgruppe Mueller. Kampfgruppe Mueller had retaken the Beresino bridgehead and then abandoned it. Lt. General Mueller had transferred his command post to Gaidukowo $(24 \mathrm{~km}$ northwest of Beresino). ${ }^{384}$ Kampfgruppe Floerke reported at $0130 \mathrm{hrs}$ that strong Soviet pressure made it necessary at dawn to withdraw to Ssmilowitschi. Lt. General Floerke reported at $0440 \mathrm{hrs}$ that the traffic through Ssmilowitschi had diminished. The troops had held the bridgehead throughout the night in costly battles. The 4th Army informed Lt. General Floerke at 0745 hrs that Kampfgruppe Floerke would have to hold on as long as possible to make contact with the XII Army Corps which was approaching from the region of Gaidukowo. Kampfgruppe Mueller was informed by radio at 0815 hrs that the situation at Minsk was unclear and the strongpoint Ssmilowitschi and Kampfgruppe Floerke were endangered.

Therefore, a rapid juncture with Kampfgruppe Floerke was necessary. Kampfgruppe Floerke reported at $0750 \mathrm{hrs}$ that the road junction north of Ssmilowitschi was occupied and Soviet columns were moving north.

The Soviet 2nd Guards Tank Corps broke into Minsk from the east on July 3, 1944 and forward elements of the 11th Guards and 31st Armies had reached the city (see Figures $128 \& 129$ ). 385 The 1st Guards Tank Corps of the 1st Belorussian Front arrived on the southeast outskirts of Minsk 4 hours after the 3rd Belorussian 
Front forces which completed the encirclement of the German 4th Army. ${ }^{386}$ The 4th Army received an urgent report around $1000 \mathrm{hrs}$ that the Soviets had entered Minsk. ${ }^{387}$ The 4th Army reported to Army Group Center at 1055 hrs that Kampfgruppe Floerke had been pushed back to Ssmilowitschi and the connection to the XII Army Corps was in progress (see Figure 129). Minsk was cleared of German troops by units of the 3rd and 1st Belorussian Fronts by the end of the day.388 Minsk had been lost and individual Soviet tanks were already between Minsk and Zaslaw (see Figure 128). The 5th Guards Tank Army passed around Minsk from the north and broke out into the area northwest of Minsk and cutoff the German retreat toward Molodeczno (see Figure 128). ${ }^{389}$ The 5th Panzer Division and 170th Infantry Division had the mission to hold open the bottleneck Molodeczno east of Radoszkowice and to block the crossings at Usza and Wilja up to Smorgonie (see Figure 128).390

Lt. General Metz clarified the situation on the north flank in his $0700 \mathrm{hrs}$ report. Elements of the 170th Infantry Division and 221st Security Division were deployed from Krasne to Smorgonie. The reserves consisted of $2 / 3$ of the 5th Panzer Division assembled in the area Krasne-Molodeczno. German rail traffic from the west could now only run as far as Smorgonie. A German pilot reported Soviet bridge construction over the Wilja river $4 \mathrm{~km}$ north of Smorgonie. The 4th Army requested air strikes on the bridge and reconnaissance northeast of Smorgonie. This request was was sent to Army Group Center and simultaneously to $\mathrm{OKH}$ and the 6th Luftflotte. 
The 4th Army Headquarters was transferred from Zaslaw to Molodeczno during the afternoon. The 4th Army Headquarters received reports in Molodeczno concerning Minsk. Minsk was lost to the Soviets around $1000 \mathrm{hrs}$ and Soviet armor was reported on the road half way between Grodek-Ostroszycki-Radoszkowice and Kosakowa as well as on the road Minsk-Zaslaw and MinskRakuw.391 Kampfgruppe von Saucken was attacking Soviet armor at Kosakowa when it received an order from General Tippelskirch to defend the land bridge from Molodeczno in the line north of Radoszkowice to Smorgonie. It was also to hold this area open for the retreating corps against the pursuing Soviets from the southeast. The 4th Army informed Kampfgruppe Mueller and Kampfgruppe Floerke at $1710 \mathrm{hrs}$ that Minsk was occupied by the Soviets and the best breakout route was through Stolpce where two Panzer divisions were being sent. 392 Kampfgruppe Gottberg was ordered at $1715 \mathrm{hrs}$ to prevent a Soviet advance from Minsk to the land bridge on both sides of Wolozyn with all available means (see Figure 128).

Kampfgruppe Gottberg with the fall of Minsk became fragmented. Field Marshal Model issued new orders for the 5th Panzer Division to attack toward Grodek-Ostroszycki.

General von Tippelskirch constructed a new front using the $60 \mathrm{~km}$ wide roadless swamp terrain of the Puszca Nalibocka woods (see Figure 129). North of the Nalibocka woods the defense was delegated to the VI Army Corps. On the left of the Nalibocka woods the XXXIX Panzer Corps was assigned this sector to defend. The 
corps defense assignment extended from the land bridge of Wolozyn to the line northeast of the swampy terrain and south of Wolozyn to the Berezina river.

A conference among 4th Army Commanders occurred during the morning of July 3, 1944. General Voelckers, Lt. General Vincenz Mueller, Lt. General Traut, Lt. General Ochsner, Lt. General Drescher, Maj. General Schuermann, Maj. General Klammt and Lt. General Trowitz were all present. ${ }^{393}$ Lt. General von Kurowski was not present. General Voelckers who showed signs of exhaustion took charge of the conference. The purpose of the conference was to determine the direction of the breakout from the encirclement. 394 The atmosphere of the conference was definitely optimistic. The notion of surrender or capitulation was never expressed or indicated.395 Lt. General Mueller complained about the excessive use of nonessential vehicles by the Panzer Grenadier Division "Feldherrnhalle." The division still had too many cars on the road which clogged the road and consumed gasoline that was needed for the assault guns. However, the main source of irritation expressed concerned the non-arrival of supplies and poor communications with 4th Army Headquarters. ${ }^{396}$ The breakout was to be conducted in two corps groups with the XXVII Corps leading the movement west. 397 The individual breakout of divisions was not discussed at this conference.

General Voelckers at the conclusion of the conference ordered the retreat to the west to begin on the evening of July 3 , 
1944. The order of battle for the breakout was organized as follows:

1. 57th Infantry Division and weak elements of the 78th Sturm Division were to advance through Samostotschje to Rudnja on the right.

2. The 31 st Infantry Division was to advance to Tscherwonnaja Sslobadka in the center.

3. The 78th Sturm Division was to advance to Beresowka on the left.

4. The 25th Panzer Grenadier Division was in the rear to first secure both sides of Ossowyj Bor as a rearguard then it could follow the other divisions. 398

The XXVII Army Corps received one 800 liter fuel drop by air to support the breakout. ${ }^{399}$ This fuel was used mostly for the command and radio vehicles of the corps staff. However, the 78th Sturm Division also received 200 liters of this fuel.

Lt. General Vincenz Mueller reported to the 4th Army at 1435 hrs that the troops of the encircled divisions had lost their combat effectiveness:

The route to Ssmilowitschi was blocked by the enemy in strength. Individual groups of tanks are approaching from the north. The route conditions are difficult. Despite stringent measures heavy congestion occurs and as a result signs of disaffection among the vast numbers of stragglers are evident. There existed no more possibilities to concentrate combat troops and artillery with sufficient ammunition rapidly enough for a planned attack because of movement problems.

Therefore, I have decided and ordered the breakout of the threatened encirclement with as many men of sound 
morale as possible with basic weapons heading south of Minsk to the west. 400

Field Marshal Model issued the following orders for further operation of the 4th Army:

1. The area of Dukora must be held by conducting a sufficient anti-tank defense to make possible a rallying point for the elements of the 4th Army still east of Minsk. The enemy following up in this direction is to be shaken off, and his actions against Minsk from the north suppressed, by a thrust of an armored group from the 5th Panzer Division from the area of Radoszkowice onto Grodek-Ostroszycki. The elements east of Minsk are to be directed westwards through Stolpce or Wolozya depending on the situation.

2. The area of Wolozyn-Molodeczno-Smorgonie was to be kept open. The enemy crossing the Wilja river north of Smorgonie is to be attacked and thrown back over the river. The neck of land between Smorgonie and the marshes south of Lake Narosz is to be blocked. 401

Soviet movement during the evening determined the possibility for construction of a new front and the fate of the encircled corps. According to recent reports an entire Soviet Tank Army was breaking through past Minsk to the south through Dsershinsk-Rubeshewitsche. Another report issued by Lt. General Lendle of the 221st Security Division at 1415 hrs based on German aerial reconnaissance reported 3 Soviet columns lead by armor advancing side by side on Minsk while German columns were only a few kilometers west of Minsk. ${ }^{402}$ The XII Army Corps had successfully fought its way through in 3 Kampfgruppen to the west in the area north of Tscherwen.403 Kampfgruppe Floerke was thrown out of Ssmilowitschi. 404 There were no reports from the 
110th infantry Division and the XXVII Army Corps. The defense of Minsk had collapsed during the morning. ${ }^{405}$ The Soviets by noon were west of Minsk and probing Zaslaw. Strong Soviet armored forces were attacking further west of Grodek-Ostroszycki and locked into combat at Kosakowa with Kampfgruppe of the 5th Panzer Division where continuous and heavy armored battles developed. Soviet reconnaissance forces northwest of Smorgonie had succeeded in crossing the Wilja river.

Lt. General Vincenz Mueller no longer believed a general breakout was possible under the circumstances. He had elected to gather what battle hardened troops of sound morale he had left and taking only infantry weapons launch a breakout. This marked an end to any effective combat operations of the old 4th Army. The encircled forces consisted of the remnants of 10 divisions of the old 4th Army, 4 divisions of the VI Army Corps, and the Panzer Grenadier Division "Feldherrnhalle."406 Therefore, a total of 15 divisions ceased to exist as combat effective units. 407

The Luftwaffe had failed to provide the necessary air support for the ground troops in their attempts to breakout to the rear. It also could not provide air cover for the rear areas to protect rail transport. The German soldier was repeatedly called upon to provide his own air defense. Previously, the Luftwaffe High Command openly stated that the enemy controlled the air by day and night. German air defense doctrine called for the employment of all weapons including machine guns and rifles against low flying air attacks. Their advice to the German Soldier about seeking 
cover during an air attack did not mean sticking their "head in the sand," but "lying on their back, raising their rifle and shooting." 408 Army Group Center also found it necessary to issue an order on July 3, 1944 to all military personnel traveling on trains. When the train under air attack halted all military personnel were to disembark and engage the Soviet aircraft with rifles and machine guns. 409

\section{9th Army}

The 12th Panzer Division had been pulled out of the front at Marina Gorka during the night and was enroute toward Stolpce. The 4th Panzer Division had commenced its attack from Nieswiez and made good progress. Horodziej was taken during the advance. The attack of the 4th and 12th Panzer Divisions to retake Stolpce had not yet succeeded. The 4th Panzer Division was stalled northeast of Horodziej by severe Soviet resistance. The 12th Panzer Division lacking reports from Stolpce dispatched a Storch aircraft to assess the situation and it was shot down over the city.

The Bobruisk troops which had escaped earlier had been moved by train to the west, but many that had escaped later were now marching on foot in stocking feet because their feet were too sore to wear boots. The lucky ones were riding in vehicles of the 12th Panzer Division and supply vehicles.

Major General von Kessel of the 20th Panzer Division concentrated the mass of motorized and horse-drawn vehicles into one group with the purpose of finding another crossing over the 
Njemen since the Soviets had occupied Stolpce. ${ }^{410}$ The Kampfgruppe of the 20th Panzer Division thrust to the northwest through partisan positions in the Nalibotski forest as far as Jeremicze where the Kampfgruppe began the construction of a bridge over the Njemen river. The 9th Army had dispatched an assault gun reinforced Kampfgruppe of the 28th Jaeger Division and a bridging column to this location. This bridge was completed by 1800 hrs on July 3rd.

The battle of Stolpce had taken an unfavorable turn. The 12th Panzer Division reached the area northeast of Stolpce, but a breakthrough appeared hopeless. 411 The spearhead of the 4th Panzer Division had failed to make any further headway by evening. The Soviets were laying down artillery fire on the rail station Horodziej where the 4th Panzer Division was being relieved by the 28th Jaeger Division which was forced to unload on the open tracks.

The 9th Army during the morning was renamed "Gruppe von Vormann" and placed under the command of 2nd Army. ${ }^{412}$ The 9th Army was to retain the designation "Gruppe von Vormann" until July 10th when the 9th Army Headquarters became fully functional again. 413 "Gruppe von Vormann" consisted of the following units:

\author{
12th Panzer Division \\ 28th Jaeger Division \\ Gruppe Harteneck: \\ 4th Panzer Division \\ 4th Cavalry Brigade \\ 1st Hungarian Cavalry Division \\ "Fortress Baranowicze"
}


and all arriving formations in this area. ${ }^{414}$

The 9th Army reported at $1330 \mathrm{hrs}$ the recovery of approximately 25,000 soldiers of various units from Bobruisk. ${ }^{415}$

JULY 4, 1944

\section{3rd Panzer Army}

A link up by 3rd Panzer Army with the 16th Army was going to be attempted through Koziany with the 215th Infantry Division from the 16th Army and Grenadier Regiment 435 and Sturmgeschuetz Brigade 393 of the 3rd Panzer Army. Meanwhile, Kampfgruppe 3rd Panzer Army was ordered to block the neck of land between Narocz lake and Dzisna, and along both sides of Postawy (see Figure 127).

The withdrawal movement by the 212th and 252nd Infantry Divisions into the old First World War positions (line of lakes directly west of Postawy) went according to plan (see Figure 127). Corps Detachment $D$ was partly transported by truck to the southern sector of its new position north of the Miadziol lakes. The 212th Infantry Division's rear guards had to fall back to the forward outposts of Miadziolka. Aerial Reconnaissance revealed that Soviet columns were advancing out of the region of Parafjanow through partisan territory to the west on the right flank of the Panzer Army (see Figure 127).416 The spearhead had reached the region directly east of Konstantynowo. Ground observation reported at $1700 \mathrm{hrs}$ that individual tanks were 
probing out of the area of Kobylnik to the north. The Soviets with the mass of their motorized vehicles had crossed the of land north of the Narocz lakes. The 3rd Panzer Army responded by dispatching a strengthened Kampfgrupppe with infantry units, Sturmgeschuetzen (assault guns), and Nashoernern (tank destroyers) under the command of Major Hoppe of the Heavy Panzer Jaeger Battalion 519 (see Figure 127).417 Major Hoppe was assigned to beat back this renewed threat of envelopment and if possible occupy the line of lakes between Narocz and Miadziol.

The necessity of stripping reserves to strengthen the right flank of the Panzer Army weakened the center sector where there were no further available reserves. The linking up with the 16th Army north of Koziany was no longer possible due to a shortage of forces (see Figure 127). ${ }^{418}$

Lt. General Krebs informed 3rd Panzer Army at 1530 hrs that it was to take over the command of Wilna.419 Contact with the Commandant of "Fortress Wilna" would shortly be arranged. Lt. General Krebs informed the Panzer Army that there was a prospect that the 6th and 7th Panzer Divisions would arrive to assist this front. Wilna was supposed to be reinforced. The supply of the Panzer Army would be based on the rail line Wilna-Kauen. Maj. General Heidkaempfer requested at $1700 \mathrm{hrs}$ that Lt. General Krebs arrange for the destruction of the Wilna river bridge at Michaliski by a low level air attack. Engineer Battalion 505 received the demolition assignment to destroy the stream crossings west and north of the northern tip of Swir lake. The IX Corps was no longer 
exposed to great danger on the southern flank because of the deployment of the 197th Infantry Division by truck. Major Hoppe's Kampfgruppe was supposed to launch a flank attack but the infantry to support and protect the Kampfgruppe's armor had not arrived from Corps Detachment $D$. The infantry riding in panje wagons would have to increase their pace in order to keep up and protect the armor.

The IX Corps rear guards were ordered to remain in the stream sector east of Postawy till 0200 hrs. Soviet armor northeast of Postawy had not yet reappeared. The battalion strength of the 212th Infantry Division averaged only about 150 men who needed food and sleep.420 The left wing of the IX Corps was located in Kurti ( $6 \mathrm{~km}$ northwest of Postawy) but because of a lack of troops contact could not be reestablished to the 16th Army through Koziany (see Figure 127).421 Maj. General Heidkaempfer knew that everything must be done to concentrate artillery against the eastern front of the corps so that the probable Soviet attack on Postawy on July 5th could be met with concentrated artillery fire. The IX Army Corps Command Post was now located at Jankiszki (5 $\mathrm{km}$ southeast of Aduliskis) (see Figure 127).

The 3rd Panzer Army defense at the end of the day was based upon the First World War position between the north edge of the Miadziol lake and the Hoduschki woods. Corps Detachment D was ordered to attack the following day and occupy the neck of land between Narocz lake and Miadziol lake. 


\section{4th Army}

The XXVII Army Corps which had been out of contact since June 30th had fought their way back and Joined Kampfgruppe Mueller in the area of Ssmilowitschi.422 Generals Mueller and Voelkers reported at 0700 hrs their decision to breakout that evening in the direction south of Minsk proposed by General von Tippelskirch.423 Army Group Center at $1530 \mathrm{hrs}$ ordered Kampfgruppe 4th Army to block the neck of land between the Nalibocka woods and the swamp terrain south of the Narosch lakes in the line forward of Wiszniew-Smorgonie and to delay the Soviets forward of this line as long as possible. Meanwhile, Soviets advancing from Minsk to the west took Rakow defended by weak security forces.

Field Marshal Model did not address the encircled divisions personally this day because he was involved in the conduct of offensive operations. The Soviets on a wide front had already crossed the road to Smorgonie at Molodeczno and west of the city. General von Saucken was forced to withdraw the Kampfgruppe 5th Panzer Division from Grodek and used it to clear the MolodecznoSmorgonie road (see Figure 130). In the VI Corps sector the Soviets forced their way into Molodeczno and Gmurgainys. Battles were still raging in these areas. Soviet forces advancing along the rail line from the northeast also took Lebicdziew. Aerial reconnaissance reported massive Soviet forces moving on the roads Bobruisk-Minsk and Mogilew-Beresino-Ssmilowitschi. 
The 4th Army reported during the evening that since June 26, 1944 the Soviets had deployed the following units against the 4th Army: 41 rifle divisions, 4 tank corps, 1 mechanized corps, 1 cavalry corps, 1 tank brigade and a large number of independent army units. ${ }^{424}$ The 4th Army reported that at least 1000 Soviet tanks had been deployed against it and 473 had been destroyed. ${ }^{425}$

The 4th Army breakout was not successful. The 78th Sturm Division, 25th Panzer Grenadier Division and 31st Infantry Division were halted in their advance to the west. ${ }^{426}$ The 25th Panzer Grenadier Division's spearhead lead by 3 assault guns was blocked by Soviet heavy weapons from any further advance $3 \mathrm{~km}$ west of Belaja-Lusha.427 The 25th Panzer Grenadier Division had saved 32 assault guns and 20 self-propelled guns from being abandoned due to lack of fuel, but these guns had mostly exhausted their ammunition and there was no further available fuel. The division had received no regular supply of fuel, ammunition and food since the Soviet offensive began on June 22, 1944.428 The only supply of ammunition left was for rifles along with some handgrenades.

The 25th Panzer Grenadier Division launched another attack consisting of only infantry leaving their vehicles behind on the road. The attack was launched through the wooded area to the right of the road by Motorized Grenadier Regiment 119 under the command of Major Koller. Motorized Grenadier Regiment 35 under the command of Colonel von Bergen was to exploit the breakthrough of the 3rd Battalion of Motorized Grenadier Regiment 119. Lt. Colonel Luick, Commander of Motorized Grenadier Regiment 119 
remained behind with the remaining units and combat vehicles. The attack failed, however, and the Soviet defense line could not be cleared by a joint effort from the west and east. Meanwhile, Soviet attacks were repelled despite a shortage of ammunition. Soldiers that had no more ammunition would have to crouch in fox holes until the Soviets were within hand-to-hand combat range whereupon the troops would jump out of their holes using empty weapons in hand-to-hand combat to repulse the Soviets. ${ }^{429}$ Soviet attacks were repulsed but the Soviets continued uninterrupted fire into the compressed cauldron with all available weapons which caused the Germans high casualties. The Command Post of the 25th Panzer Grenadier Division was at Belja Lusha and the XXVII Army Corps Command Post was at Basseka.

\section{2nd Army}

Gruppe General von Vormann. On the right wing of Gruppe Lt. General Harteneck the Soviets were advancing from the southeast directly south of the rail line west of Siniawka. On the left wing of Gruppe Harteneck the Soviets encircled Nieswicz and took Kleck from the 1st Hungarian Cavalry Division. The 4th Panzer Division was assembling around the town of Snow. The 4th Panzer Division received the mission to attack to the south to prevent a Soviet breakthrough at "Fortress Baranowicze" (see Figures $130 \& 131$ ). 430 The 12th Panzer Division was fighting its way back to the west and had abandoned its attack toward Stolpce. The 28th Jaeger Division and Kampfgruppe Lt. General von Kessel were to establish a 
security line on the Usza sector facing northeast. The Soviets were reported to have already occupied Turzec in this sector. Army Group Center in sorting out the available divisions of the 9th Army decided that the following divisions were still operational: 35th, 102nd, 129th, and 292nd Infantry Divisions. ${ }^{431}$ The remaining 9th Army divisions could not be used as divisions. 432 The 20th Panzer Division was to be restored and all available elements made combat ready.

$$
\text { JULY 5, } 1944
$$

\section{3rd Panzer Army}

The Soviets attacked the south wing of the IX Army Corps during the night and broke into the German positions at Laposie and Mikitki. The Soviets also took Juodaciai. There was already a hole in the direction of Wilna which kept growing larger with the gap between the 3rd Panzer Army and the 4th Army (see Figure 130). There was still no contact with Army Group North yet. 433 Reconnaissance reported that Tverecius (18 km north of Aduliskis) was occupied by the Soviets. The Soviets attacked the eastern front of the Panzer Army from the right wing to the hills at Postawy with heavy casualties (see Figures $130 \& 132$ ).

Maj. General Heidkaempfer advised Army Group Center that the position in the southern sector could not be held any longer. A withdrawal to the Aduliskis line (see Figures 130 \& 132) during the night was proposed. The Chief of General Staff informed 
Colonel General Reinhardt that both sides of Postawy could no longer be held and the right wing was already southeast of Svencionys (see Figure 132). A withdrawal was ordered for that night. The new Panzer Army Command Post was to be established in Sirvintos. 434

"Fortress Wilna" was to be placed under the command of the 3rd Panzer Army during the discussion at 1500 hrs between Col. General Reinhardt, Field Marshal Model, and General von Tippelskirch at the Wilna airport. ${ }^{435}$ However, the formal subordination of the city would occur later. The discussion was shifted at $1630 \mathrm{hrs}$ to the subject of Wilna's defense with the Commandant of "Fortress WIna," Major General Poel.436 "Fortress Wilna was merely a notion without combat troops. The strength of the garrison consisted of 1 battalion from the 170th Infantry Division, 3 companies of stragglers with engineer platoons, 4 Flak batteries, and 1 military police company. ${ }^{437}$ "Fortress Wilna" was officially placed under command of Col. General Reinhardt of the 3rd Panzer Army at 2000 hrs.438 Hitler wanted Wilna held and the following reinforcements were to be sent to Wilna:

2 Valkyrie Regiments $(1068,1069)$, Hitler's "Escort Battalion" (Battalion von Werthern), 761st Brigade (partially motorized), Anti-tank Battalions (PAK) $(1059,1060)$, 1 combat battalion 1041 for the 252nd Infantry Division. 439

The arrival of these reinforcements was expected by July 6 th in the afternoon. 
The 225th Infantry Division was requested for Podbrodcie. However, the 225th Infantry Division had just begun assembling in the area of Dukstas-Turmont for an attack to restore the front between Army Group North and 3rd Panzer Army.440 No other divisions were available from Army Group North. The 225th Infantry Division would be available at the earliest by July 10th after unloading from rail transport. The first transport will roll through Duenaburg on July 7 th.

Major General Heidkaempfer oriented the Commandant of "Fortress Wilna" at 2100 hrs about the enemy situation. Soviets had been observed advancing toward Wilna from the direction of Aschmena (see Figure 130). Soviets were also reported at 2030 hrs to have broken through at Lentupis moving further to the west (see Figure 132). Aerial reconnaissance identified groups of Soviet armor and a Soviet motorized group moving west toward Podbrocie. Contact between Army Group North and 3rd Panzer Army still had not been restored during the day. ${ }^{441}$

\section{4th Army}

Both the XII Army Corps and the XXVII Army Corps were moving west (see Figure 130). The XII Corps was located in the woods south of Pekalin at the road intersection $(4 \mathrm{~km}$ south of Pekalin). Both corps after heavy battles had lost most of their supplies and artillery. The corps were going to advance south of Minsk on the line Dsershinsk-Zaslaw and then turn northwest in the direction of Wolozyn-Dubina.442 A supply drop was requested that 
night at Bridgehead Wolma where 8 fires in a square would provide recognition for the air drop.

A message from the XXVII Corps at 1420 hrs stated:

All attempts to force a way out with our last resources have failed. The Corps is on the defensive. ${ }^{443}$

General von Tippelskirch replied by radio at $2300 \mathrm{hrs}$ to the XXVII Army Corps:

With deep emotion and shattered by the feeling that we can do nothing to help, your old true Comrade-in-Arms salutes the Army. General von Tippelskirch.444

The XXXIX Panzer Corps was now $40 \mathrm{~km}$ southeast of Minsk (see Figure 130).

The Soviets broke through the VI Army Corps in the evening with 15 tanks and became entangled with Kampfgruppe Lt. General von Bergen at Wolozyn (see Figure 130). These Soviet tanks were repulsed after 6 were knocked out (see Figure 130). Nevertheless, Grodek and Wolozyn were lost on the new 4th Army front by the end of the day. Field Marshal Model ordered the 4th Army to assemble for defense of the neck of land between the Naliboki woods and the swamp terrain east of Smorgonie.445 The PanzerKorps von Saucken (XXXIX Panzer Corps Headquarters, 5th and 7th Panzer Divisions) were to attack northwest of Smorgonie to the north to repulse the Soviets which had crossed over the Wilja river and were advancing on Wilna (see Figure 130).446 The connection with the south wing of the 3rd Panzer Army was to be restored. However, The 170th Infantry Division under Kampfgruppe von Saucken was thrown out 
of Molodeczno and Smorgonie (see Figure 130). The new defensive line was located on the edge of the hills on both sides of Markowo. Elements of the 221st Security Division west of Smorgonie repulsed a Soviet armored thrust (see Figure 130).

A conference of the surrounded 4th Army Generals was held at $1630 \mathrm{hrs}$ and attended by General Voelckers, Traut, Trowitz, Klammt and Schuermann.447 Generals Drescher and Ochsner were not present. General Voelckers stated that all breakout attempts had failed for days. It was finally time to take a defensive posture. Maj. General Schuermann inquired what purpose this measure would serve. He asked, "Will the Corps be broken out from outside the encirclement by German forces?" General Voelckers responded: "There were no available forces. The objective was defense against Russian pressure for 2-4 days followed by surrender of the entire Corps."448 Maj. General Schuermann requested permission for his division with empty weapons to breakout. General Voelckers refused his request. General Voelckers stated:

The Russians have advanced further than $100 \mathrm{~km}$ to the west, you will enter new encirclements again and again, and in my opinion will fail to return to the homeland. When we surrender ourselves, the chance exists, that at least the men may save their lives. Besides think of your wounded. In an orderly surrender to the Russians the chance exists that they will be provided for. 449

Finally, General Voelckers departed from the conference and Maj. General Schuermann conferred with the remaining Division 
Commanders. He stated: "Can no commander make the best of things."450 Lt. General Trowitz who had previously underwent encirclement at Tscherkassy and Maj. General Klammt agreed immediately with the view of Maj. General Schuermann. Lt. General Traut, however, continued to vacillate between the breakout and surrender. Later, Lt. General Traut decided in favor of the breakout. 451

The final conference of the surrounded 4th Army Generals assembled under the direction of General Voelckers at 1900 hrs. 452 There were only 4 generals at this meeting. General Voelckers informed them that Lt. General Drescher, Commander of the 267th Infantry Division had just reported Russian breakthroughs on the eastern front of the Corps in two places. General Voelckers now granted his permission to all the generals to breakout.453 The 4 Division Commanders agreed that each general would breakout on his own front separately.

The 25th Panzer Grenadier Division's sector during the day had not changed. The Soviets continued to attack from the west to the east. The Soviets were repulsed in hand-to-hand combat and the last handgrenades had been used. 454 There was now a shortage of rifle ammunition with no more than 10-15 rounds per rifle. The situation was becoming critical. The 25th Panzer Grenadier Division now had 600 wounded receiving no medical care. It was similar for the other divisions, the 57th Infantry Division had 1000 wounded, the 260th Infantry Divisions had 800-1000 wounded. 455 Medical supplies were no longer available. Maj. General 
Schuermann ordered a reconnaissance of the Soviet lines to determine the position for the breakout.

Maj. General Schuermann issued the order to breakout to his commanders at $2000 \mathrm{hrs}$. He divided the division into 3 attack groups:

1. Colonel von Bergen with Grenadier Regiment 35 on the right.

2. Maj. General Schuermann in the center with the artillery section of the Panzer Jaeger Battalion, the engineer battalion and elements of Grenadier Regiment 119.

3. Lt. Colonel Luik with Grenadier Regiment 119 on the left. 456

The three groups were to be in position at Welikij-Less at midnight for the attack.

The wounded were entrusted to the care of a doctor, who was left in possession of a letter with an appeal to the military honor of the Russian commander. The artillery was destroyed once the ammunition had been exhausted.

The objective of the attack was to reach Koidenowo (southeast of Minsk) which was also known as Dserhinsk. Maj. General Schuermann proceeded to the assembly point at $2200 \mathrm{hrs}$. The assault of the 25th Panzer Grenadier Division took place at midnight with shouts of "Hurra" and empty weapons. 457 The breakout succeeded but many wounded were left behind in the dark during the assault. 
The other two main groups were under the command of Lt. General Traut southeast of Volma and Lt. General Mueller east of Volma.458 Both of these groups attempted to breakout to the west, southwest and south toward the area of Baranovichi (see Figure 130). The Soviet 53rd Army of the 1st Belorussian Front and the 50th and 49th Armies of the 2nd Belorussian Front continued to surround and compress the pocket containing the German 4th Army. 459

\section{2nd Army}

Kampfgruppe Lt. General Richert (part of the LV Army Corps) had reached the west bank of the Sslutsch coming from the area Ssosnkowitsche. The 292nd Infantry Division was advancing along the rail line Luniniec-Baranowicze to restore contact to the southern wing of Kampfgruppe Lt. General Harteneck (see Figure 133). 460

Kampfaruppe General von Vormann. The Soviets broke through the north wing of the 4th Cavalry Brigade with 10 tanks and 6 were knocked out (see Figure 133). The 4th Panzer Division attacking from Snow to the southwest liquidated this breakthrough (see Figure 133).461 Soviet forces on the north wing of Kampfgruppe von Vormann had crossed over to the west bank of the Usza river. Aerial reconnaissance confirmed the presence of numerous tanks. The 28th Jaeger Division gained only limited ground against these Soviet units (see Figure 133). The 12th Panzer Division which had made contact and linked up with numerous straggler units crossed 
the Niemen river at Jeremicze (see Figure 133). Kampfgruppe von Vormann was able to repulse Soviet breakthroughs toward Baranowicze (see Figure 130).462 The construction of a new defensive front behind the present front had begun. The rebuilding and reorganizing of smashed divisions was also in progress.

The Soviet plan of attack by using a multiple axis advance starting with 6 major points of concentration combined with objectives in depth had achieved an outstanding success. Soviet offensive operations from June 22 nd to July 5 th had virtually liberated most of White Russia (see Figure 134).

$$
\text { JULY 6, } 1944
$$

\section{3rd Panzer Army}

The Chief of the General Staff ordered the Commandant of "Fortress Wilna" to blow all the bridges from Niemenczyn to the edge of the city. 463 The bridges around the city still being used were to be manned by security forces. General Poel reported that all bridges that lead from Wilna to the east had been destroyed three days ago.

The 212th Infantry Division rearguards were closely engaged by the Soviets. Elements of the division were engaged on the east edge of the woods $3 \mathrm{~km}$ east of Lentupis. The security troops under Soviet pressure withdrew from Lentupis (see Figure 135). The Soviets attacked the IX Corps in the morning in the rear of its right wing and Kampfgruppe Corps Detachment $D$ from the south. (see 
Figure 136). The Soviets advancing from the area of Tverecius attempted to outflank the north flank of 3rd Panzer Army by thrusts from the east and north. The Soviet forces advancing in the south encountered only extremely weak German resistance. The Soviets in the north were moving along the road from in the northeast in the direction of Svencionys (see Figure 135). The IX Corps was assigned the general task of providing the "defense for Duenaburg." Meanwhile, a $155 \mathrm{~km}$ hole remained between the 3rd Panzer Army in the south and the 4th Army in the north (see Figure 136). 464

The gaping hole between the 3rd Panzer Army and 4th Army created major problems for the defense of Wilna (see Figure 136). Lt. General Krebs advised Colonel General Reinhardt that one Valkyrie Regiment would be in Wilna today and tomorrow another regiment and the Fuehrer Begleit Battalion would be in Wilna. Colonel General Reinhardt informed Lt. General Krebs that 3rd Panzer Army could only fulfill one mission, either the northern operation with the 252nd Infantry Division or the defense of Wilna. ${ }^{465}$ Reinhardt stated:

The notion of fortresses is pure nonsense. There are no forces and also no suitable headquarters available for the defense. When the Soviet main effort is on Wilna, the 3rd Panzer Army Headquarters perceives that establishing contact with Army Group North had greater importance since the Army can at least go on controlling such troops as it still possesses. 466

Lt. General Krebs informed the 3rd Panzer Army at 1040 hrs of Field Marshal Model's decision. The main effort of the 3rd 
Panzer Army was to be centered on Wilna.467 Panzer Platoon 21 had already arrived and was to move up in the direction of Podbrodcie. Elements of the 170th Infantry Division had arrived in Wilna and were to make contact with the IX Corps to the north.

Army Group Center reported at 1045 hrs that the following units were en route to Wilna: Infantry Battalion 1041 in Lublin, Valkyrie Regiment 1067 in area of Bialystok, Valkyrie Regiment 1068, Valkyrie Regiment 1069, Infantry Brigade 761 from Kauen, and Fuehrer Begleit Battalion von Werthern which would depart Arys on July $6,1944.468$

The 225th Infantry Division would be transported by rail and employed on the south wing of the Panzer Army to close the hole between the 4th Army and 3rd Panzer Army.469

Soviet forces in the wooded terrain northwest of Lentupis advanced further to the north to the region of Paginiai (see Figure 135). Soviet attacks east and northeast of Aduliskis suffered heavy casualties, but forced the north wing of the Panzer Army during the morning to be pulled back in the line AduliskisMelagenai (see Figure 135).

Colonel General Reinhardt visited the command post of "Fortress Wilna" during the afternoon and discovered that there had been no further reinforcement of the garrison. Reconnaissance reported at $1230 \mathrm{hrs}$ that 8 Soviet tanks and accompanying infantry had apparently crossed the Wilja river before the demolition of the bridge at Mikalischki. The inner defenses of Wilna was organized into a series of defense positions and a main 
battle line that was weakly occupied on the northern arc and more strongly occupied on the eastern arc. Road obstacles were prepared, however, there were no mines. Railroad engineers had prepared demolition charges at the entrances to the city. The air defense was reinforced by ten $88 \mathrm{~mm}$ cannons. These guns would be complemented by four full strength batteries of $88 \mathrm{~mm}$ guns and a Flak Kampftruppe during the night of July 7th. These $88 \mathrm{~mm}$ guns could be used as potent anti-tank guns as well as air defense guns. Col. General Reinhardt stressed the importance of protecting the most important bridges to the Flak Commander. Panzer platoon 21 was sent to reinforce the security line east of the city. The supply situation in the city had improved with rations for 30,000 men for 21 days stockpiled.470 Two more infantry battalions had arrived by the end of the day in Wilna. One battalion was deployed on the northern sector and two battalions were kept in reserve.

Soviet pressure against the eastern front of the IX Army Corps increased. However, two Soviet battalions were annihilated in Lentupis. The motorized Army Engineer Battalion 505 with the support of assault guns was given credit for the success of the counterattack which retook the town. The Commanding General of the IX Corps reported the especially dangerous situation at Lentupis at $1930 \mathrm{hrs}$ to Col. General Reinhardt. Corps Detachment D was withdrawing on the rail line northeast of Lentupis (see Figure 135). The IX Corps was going to hold the elevated terrain 8 $\mathrm{km}$ southeast of Svencionys as long as possible (see Figure 135). The 391st Security Division had practically disintegrated. ${ }^{471}$ The 
IX Corps reported that it disengaged from the Soviets and the right wing of the Corps was on Soros lake in the line Perszukszta-both sides of Svencionys-line of lakes northeast of Svencionys-and the lake at Koncerzina (see Figure 135). This line was to be held as long as possible to allow the 225th Infantry Division to unload its advance elements on July 7 th (see Figure 135).

The arrival of the 6th Panzer Division had been anticipated so some of the bridges over the Wilja river had not been blown up earlier and this represented a dangerous situation since the 6th Panzer Division would not arrive till July 10th at which time the bridges would have to all be blown up. 472 Meanwhile, the first trains loaded with reinforcements for Wilna arrived at 1800 hrs with elements of Infantry Brigade 761, Panzer Grenadier Brigade von Werthern, and Valkyrie Regiments 1068 and 1069.

\section{4th Army}

There were no reports from the XII and XXVII Army Corps today. 473 The Soviets advanced southwest from Molodeczno and reached the wooded terrain northwest of Wiszne. The elevated terrain around the city was held. Elements of the 7th Panzer Division were employed to hold the line here, and also attack to the north to cut off the Soviet units which had broken through the defense line. The 5th Panzer Division was successful in closing the hole south of Smurgainys by attacking east from Krewe to the north. Soviet attacks through Ziuprenai and deep into the flanks forced the withdrawal of the line $11 \mathrm{~km}$ southeast of Krewe $9 \mathrm{~km}$ 
northeast of Krewe-Aschmena. Soviet forces outflanking the 4th Army advanced into the hole between the 3rd Panzer Army and 4th Army (see Figure 136). Soviet motorized forces moved through Smurgainys and Mykoloskis against Wilna (see Figure 136).474

The 25th Panzer Grenadier Division during its successful breakthrough ran into a hail of Soviet fire from artillery, tanks, anti-tank guns and mortars. Maj. General Schuermann's

Kampfgruppe burst through the Soviet lines, but out of the original 1000 men only 100 survived.475 Colonel von Bergen, Commander of Motorized Grenadier Regiment 35 was killed in the breakout and Lt. Colonel Luick, Commander of Motorized Grenadier Regiment 119 was severely wounded and most probably taken prisoner.476 The remnants of the division were broken down into small groups of 30-50 men. Maj. General Schuermann's Kampfgruppe crossed the rail line Bobruisk-Minsk with 80-90 men moving south, but after three futile attempts no breakout was achieved.477 Maj. General Schuermann decided to swing back around Minsk to the north and then turned west and broke through with his dwindling detachment north of Molodeczno and south of Wilna past Mereczsanka.478 A difficult crossing of the Njemen river was achieved after a sharp fight with Soviet troops for the control of a pontoon bridge.479 Finally, Maj. General Schuermann and his Kampfgruppe of 35 men reached German lines on August 17, 1944 southeast of Sudauen. 480

Lt. General Traut's group tried to breakthrough to Dzerzhinsk, but was destroyed by the Soviet 49th Army of the Soviet 2nd Belorussian Front.481 Between Minsk and Baranowitschi the 
majority of the 78th Sturm Division under the command of Lt. General Traut had assembled in a village which had become surrounded by Soviet infantry on all sides. The Soviet infantry launched a sudden attack from all sides with shouts of "Hurra" and stormed the village killing the wounded and taking Lt General Traut and the remaining soldiers prisoner.482 Lt. General Traut raised his hands and surrendered according to one survivor. 483

Lt. General Muellers Kampfgruppe broke through to the Ptich river south of Minsk and attempted to seize the airfield at Ozertso $12 \mathrm{~km}$ southwest of Minsk but failed.

The Soviets had taken extensive measures to prevent the infiltration of German troops to the rear and at the same time began exploiting the newly occupied areas for military manpower. Maj. General Schuermann was the only German General of the 4th Army to survive and escape Soviet captivity. He delineated the Soviet measures he encountered in his retreat to German lines as follows:

1. Russian hunting detachments in strengths of 3-15 men strongly armed with machine guns and machine pistols scoured the terrain.

2. Partisans were deployed as militia in the villages to prevent the population from helping the Germans by strict surveillance.

3. Conscription detachments covered the land. The men between 17 and 45 years of age were mobilized for military service. The horses and grain were seized. 
4. Slow moving aircraft scoured the area and the located Germans were reported by radio to hunting detachments or combat aircraft.

5. Construction of blockade lines were organized. ${ }^{484}$

\section{2nd Army}

Kampfaruppe von Vormann. The Soviets broke through on the right wing of the 1st Hungarian Cavalry Division on both sides of the road to Brest-Litovsk and achieved deep breakthroughs on both sides of Lachewicze against the 4th Cavalry Brigade. The attack of the 28th Jaeger Division and 12th Panzer Division in an attempt to cut off the Soviets west of the Usza sector failed. Kampfgruppe von Vormann was withdrawn to the Myszanka sector (south of Baranowicze) - east edge of Baranowicze - Cyryn Korelicze (see Figure 136).485 Elements of the 12th Panzer Division thrust into the rear of the advancing Soviets from the north.

$$
\text { JULY 7, } 1944
$$

\section{3rd Panzer Army}

The Wilna city defenses were attacked by two battalions of National Polish patrisans during the early morning hours which were repulsed (see Figure 137). The bridge at Niemenczyn was blown up during the night by German troops. Air force reports observed strong Soviet reconnaissance forces moving toward Wilna which were engaged by the Luftwaffe and 8 Soviet tanks were destroyed (see Figure 137). Maj. General Heidkaempfer, Chief of 
Staff 3rd Panzer Army informed Lt. General Krebs, Chief of Staff Army Group Center of the situation. The 225th Infantry Divison had not arrived from Army Group North. Lt. General Krebs assured Heidkaempfer that a parachute regiment would be flown into Wilna on July 8th.486 Therefore, the airport was not to be destroyed prior to their arrival. Maj. General Heidkaempfer requested air reconnaissance between Wilna and the right wing of the IX Corps to ascertain the position of Soviet forces west of Narocz lake (see Figure 137). The first train carrying Panzer Brigade von Werthern arrived in Kauen at $1215 \mathrm{hrs}$. These elements were directed to advance through Wilkomir to Sirvintos.

The withdrawal of the IX Corps was executed according to plan but was pursued by the Soviets on a broad front (see Figure 138). The Soviet main effort was focused on both the main roads leading to Svencionys and on the left flank of the 252nd Infantry Division (see Figure 138). The wooded terrain southeast of Svencionys was penetrated by 600 Soviet infantry and several tanks while German troops were still engaged north of this position (see Figure 138). The Soviets continued their advance to the west along both sides of the main road east of Kukiskiai. Maj. General Heidkaempfer reported to Lt. General Krebs that Soviet forces were advancing on the left wing of the IX Corps toward Ignalina and they were encountering no German resistance (see Figure 138).487 Therefore, the left wing of the IX Corps was open again (see Figure 138). The Soviets were also advancing southwest of the right wing of the IX Corps toward Podbrodzcie. 
Colonel General Reinhardt informed Lt. General Krebs that the Soviet 3rd Mechanized Corps with 4 brigades was prepared to attack Wilna. Col. General Reinhardt considered pulling back the defense line to the west bank of the Wilja-Neris because the terrain in this area offered better possibilities of defense since there was a shortage of forces and supplies for the defense of "Fortress Wilna." Lt. General Krebs response to this proposal was that the mission of Kampfgruppe 3rd Panzer Army remained twofold:

1. The containing of the Soviet advance as long as possible.

2. The holding of "Fortress Wilna" for the approaching German forces. ${ }^{488}$

The 225th Infantry Division was to be employed to cover the lakes on the right flank of the 16th Army. In case the Soviets occupied the rail line at Ignalina then the 225th Infantry Division would be employed to clear the Soviets from the rail line (see Figure 138). The Fuehrer Begleit Battalion was to be used north of Wilna in an eastward direction. Currently, the battalion was unloading in Kauen. Lt. General Krebs assured General Poel that the parachute regiment would arrive today in Wilna. Maj. General Heidkaempfer stressed the decisive importance of Army Group North blocking the area between the Dringa Lake and Dysna lake.

The Soviets during the early afternoon pushed the German forces back west of Ignalina and cut the crucial rail line WilnaDuenaburg (see Figure 138). ${ }^{489}$ Paluse was lost at 1500 hrs from 
an attack from the southeast (see Figure 138). The Commandant of Wilna was notified at $1230 \mathrm{hrs}$ that the parachute regiment would land at the airport and it was then to be deployed to the north. Meanwhile, Grenadier Brigade 761 arrived in Wilna without its equipment. The airport at Wilna was to be kept open for the arrival of the parachute regiment and then was to be blown up no later then 1600 hrs. 490 The forces arriving in Wilna were concentrated into one unit. The Parachute Regiment 16 and the 1st Parachute Engineer Battalion of Parachute Regiment 21, Grenadier Brigade 761 and Panzer Grenadier Brigade von Werthern were combined and placed under the command of Lt. General Bergen of the 390th Field Training Division.

Lt. General Krebs notified Maj. General Heidkaempfer that Hitler had issued a "Fuehrer Befehl: "Fortress Wilna" was to be held under all circumstances. The fortress must allow itself to be encircled if necessary."491 Major General Heidkaempfer responded to Lt. General Krebs that "the situation at Wilna was developing exactly like Vitebsk."492 Krebs responded that he did not believe this was the case because "the Panzer Army was $300 \mathrm{~km}$ closer to German military bases and Wilna was facing only 3 mechanized Brigades not rifle corps and tank corps."493

The IX Corps in its fighting withdrawal was pursued on a wide front southwest, east and northeast of Svencionys (see Figure 138). The Soviets in the south had reached the rail line at Podbrodszie.

Lt. General Krebs informed the Panzer Army just before midnight that General Stahel was appointed the new Commandant of 
"Fortress Wilna."494 Major General Heidkaempfer reported that the Soviets were already on the west bank of the Wilja river and had blocked the arterial road to Wilkomir with anti-tank gun fire. 495 Major von Werthern, Commander of the Fuehrer Begleit Battalion could no longer get out of Wilna except through Kauen to reach the Panzer Army Headquarters. The Soviets had pushed their way to within 200 meters of Wilna's eastern defense line (see Figure 139). The anticipated parachute regiment had not arrived except for the regimental staff and two companies. The Soviet crossing of the Wilja river was certainly possible because the police battalion from Police Regiment 16 had failed to secure the area. Anti-tank guns, Flak Kampftruppen and two Latvian police companies were withdrawn from the German bridgehead at Nowa Wilejka (see Figure 139). It was hoped with these forces the Soviets could be delayed until the last train arrived in Wilna. Soviet armor now appeared before the entire front. General Poel believed that Soviet armor had bypassed the airport and therefore it was still safe for Junker 52 aircraft to land with troops. ${ }^{496}$ Maj. General Heidkaempfer requested to be informed immediately when the landing of Junker 52 transport aircraft was no longer possible due to Soviet operations. ${ }^{497}$ Meanwhile, Panzer Grenadier Brigade von Werthern was still coming out of Wilkomir. The Panzer Army had requested to employ Panzer Grenadier Brigade von Werthern on the west bank of the Wilja river, but Hitler insisted that the brigade be placed into "Fortress Wilna." 498 
The IX Corps would have to withdraw again to avoid being outflanked. The Soviets occupied Ignalina and had crossed the rail line at Podbroczie heading west. The new resistance line was: Orinos Lake - length of Zeimena river and the Zeimena lake chain to the chain of lakes west of Ignalina. Contact with the arriving 225th Infantry Division was to be established.

\section{4th Army}

There was no radio contact from the surrounded Divisions of the 4th Army.499 The last contact had been the messages received on July 5,1944 . General von Tippelskirch sent one last message to the XII Army Corps:

Everlasting thanks for your courage and heroism. May it bear fruit despite all. 500

Meanwhile; Soviet aircraft dropped propaganda leaflets on the surrounded troops which stated:

\section{LAST WARNING}

German soldiers surrender, further resistance is senseless. Army Group Center has been completely destroyed, your comrades have deserted you...Lay down your weapons and come out of the woods in lines with white flags. ${ }^{501}$

The eastern front of the new 4th Army had been penetrated northeast of Krewe and pushed back to a line $10 \mathrm{~km}$ west of Krewe (see Figure 137). The north wing of the army was forced back through Aschema by strong Soviet reconnaissance forces. The 4th Army was in the process of withdrawing to a new line Surwiliszki- 
Medinikaj. Field Marshal Model assigned the 4th Army the task of delaying the Soviets advancing toward Wilna along the rail line Molodeczno-Wilna by attacking with mobile forces the southern flank of the Soviets (see Figure 137). 502

Kampfgruppe Weidling holding the line with weak police forces east of Lida was pushed back to the west by Superior Soviet cavalry and armor forces (see Figure 137). This made it possible for the Soviets to breakout of the Naliboki woods. Soviet armor was moving along the Molodeczno-Lida rail line and had reached the region northeast of Lipniczki (see Figure 137). Kampfgruppe Weidling was subsequently placed under the command of the 4 th Army at $2300 \mathrm{hrs}$.

\section{2nd Army}

The Soviet breakthrough attempt on the southern wing of Kampfgruppe von Vormann resulted in a deep penetration on the 1st Hungarian Cavalry Division's sector (see Figure 137). However, the Soviet attacks southeast of Baranowicze and on the north wing of the Kampfgruppe were mostly beaten back (see Figure 137). The encirclement of "Fortress Baranowicze" was prevented (see Figure 137). 503 
JULY 8, 1944

\section{3rd Panzer Army}

The Soviets closed the ring around "Fortress Wilna" which was defended by 8 battalions (see Figure 140).504 The 5th Guards Tank Army and the 3rd Guards Mechanized Corps had broken through to the city fortifications and breached them and encircled Wilna from the north and south in cooperation with the Soviet 5th Army (see Figure 140).505 General Stahel reported to the Command Post of the 3rd Panzer Army for a briefing as the new Commandant of "Fortress Wilna." The road between Wilkomir and Wilna had been disrupted by the Soviets so General Stahel flew by Storch aircraft into Wilna (see Figure 140). The Panzer Grenadier Brigade von Werthern coming from Kauen reached the Army Command Post which had taken shelter in a rail station as a result of an air attack. Major General Heidkaempfer informed Lt. General Krebs of the situation at Wilna and wanted to know what forces would be used on the front when Wilna was encircled.506 Lt. General Krebs stated that the 131st Infantry Division and other units would soon be arriving. The IX Corps was to be strengthened on the southern wing while the northern wing was left to Army Group North to reinforce. The 225th Infantry Division would soon be arriving on the southern front of the IX Corps.

The Panzer Grenadier Brigade von Werthern was requested to be employed up to $20 \mathrm{~km}$ northwest of Wilna in order to free the west bank of the Wilja river to the north. The Brigade was, 
however, to be based in Wilna. The 131st Infantry Division coming from Grodno was to be employed upon arrival to free the area south of Wilna. The 5th Panzer Division was in the area $30 \mathrm{~km}$ southeast of Wilna to cover the city from the south.

Soviet armor was reported entering Nowosiolki southeast of Wilna. Soviet armor was also reported blocking the main road Wilna-Wilkomir by tank fire (see Figure 140).507 A report by an officer was received at $1200 \mathrm{hrs}$ that the Soviets were on the road to Sirvintos southeast of Mejszagola (see Figure 140). This prompted the transfer of the 3rd Panzer Army Command Post to Wilkomir.508 Later in the afternoon the Command Post moved to Gut Leonpol (4 km southwest of Wilkomir). ${ }^{509}$ Meanwhile, numerous attacks supported by armor were repulsed on the southern and eastern front of Wilna (see Figure 140). A heavy engagement for both sides of a railroad tunnel southwest of Wilna occurred. Soviet reconnaissance thrust through Mejszagola to the northwest pushing back weak German forces $7 \mathrm{~km}$ northwest of Mejszagola. The Panzer Grenadier Brigade von Werthern coming out of Wilkomir received the order to establish a bridgehead on the south bank of the stream northwest of Mejszagola (see Figure 140).

The Soviets pursued the withdrawal movement of the 212th and 252nd Infantry Divisions of the IX Corps to the Zeimena sector slowly (see Figure 141). The 391st Security Division established a defensive line on the right flank of the Corps. The pressure on both sides of Svencioneliai mounted and Maj. General Heidkaempfer 
requested Luftwaffe support (see Figure 141). The Soviet 43rd Army was responsible for the operations against the IX Corps.

The arrival of the Soviet 39th Army on the front before Wilna was confirmed so that another 6 divisions and two tank brigades would shortly enter the battle. The Commandant of Wilna sent two messages during the evening:

Heavy combat in the evening, further terrain loss, northwest bank abandoned. Panic. The situation of the troops for tomorrow is very grave. Thrust from Ludwino from the east and heavy battles on the west wing and strong Soviet forces had been detected at Nowosiolko. A total of 18 tanks had been knocked out. 510

The second radio message followed:

Condition of the troops is so serious that disintegration by midday tomorrow is probable. Ammunition shortage. If remnants are to be rescued, a breakout in the direction of the west must be authorized at 0200 hrs. ${ }^{511}$

\section{4th Army}

Kampfgruppe General Weidling pulled its right wing back to NowoGrodek and Usielub (see Figure 142). Soviet attacks forced a further withdrawal to the west to Molczadz and the Nieman river. Strong Soviet cavalry forces breached the thin German security line and Soviet armor entered Lida (see Figure 142).512 The rail line to Wilna north of the city had been crossed by Soviet forces moving west (see Figure 142). 
Kampfgruppe Mueller during the night of July 8, 1944 attempted to breakout across the Ptich river in the region of Samokhvalovichi. The Soviet 121st Rifle Corps of the 50th Army defeated Kampfgruppe Mueller decisively.513 Lt. General Mueller surrendered and made the following statement during interrogation by the Soviets:

Our position had become intolerable. We found ourselves isolated. We had born enormous losses. Thousands of soldiers had been wounded. They were left without attention of any kind, since there was no possibility of helping them. Everyone was starving. ${ }^{514}$

Lt. General Mueller accepted the Soviet terms of surrender and on July 8, 1944 issued the following order:

To the soldiers of the 4th Army located east of the Ptich River!

After a week of heavy fighting and marches our position has become hopeless... Our fighting ability has fallen to the minimum, and there is no hope of supplies. The Russians, according to information from the High Command, are at the city of Baranovichi. The last paths...have been cut off to us. There is no hope of breaking out of here with our forces and equipment. our formations are scattered in disorder. A Colossal number of wounded have been abandoned without any aid. Having been given further information about the terms of capitulation proposed by the Soviet command group, Gen. Mueller gave the order to "cease fighting immediately. "515

Thus, the mass surrender of the remnants of the German 4th Army began. 
2nd Army

Kampfgruppe von Vormann. The main battle line was broken in several places by Soviet attacks. The Soviet 28th and 65th Armies reinforced their attack on Baranowicze with the 4th Guards Cavalry Corps and the 9th Tank Corps from the north. The 4th Guards Riffe Corps and the 1st Guards Tank Corps were employed in the south against Baranowicze. This added reinforcement allowed the Soviets to take Baranowicze (see Figure 142). The attack on both sides of Baranowicze from the north and south broke through permitting the city to be taken by a frontal assault in the early hours of July 8,1944 (see Figure 142). ${ }^{516}$ The Soviets breached the front of the 1st Hungarian Cavalry Division and reached the rail station Lesna and the road to Slonim northwest of the rail station. The Soviets occupied Nowa Mysz west of Baranowicze (see Figure 142). The 28th Jaeger Division northwest of Baranowicze resisting the Soviet attack suffered the loss of 1 infantry and 1 artillery battalion which were cutoff from the rest of the division. 517 The Soviets reached Dworzec and crossed the Molczadz river to the west. The 12th Panzer Division was withdrawing from the area southwest of Nowogrodek and advancing from the northwest on Dworzec. 
July 9,1944

\section{3rd Panzer Army}

The 3rd Panzer Army informed Army Group Center that the only way to stabilize the 3rd Panzer Army front was to expedite the closing of the hole between 3rd Panzer Army and the 16th Army. 518 The Panzer Army required more than the 225th Infantry Division to close the hole north of Wilna. One infantry Division and one Panzer division were needed in addition to close the gap.519

The Commandant of Wilna had proposed to breakout, but Hitler's orders to hold Wilna under all circumstances was received at $0230 \mathrm{hrs} .520$ Everything was being done in the way of attacks to relieve Wilna. Maj. General Heidkaempfer noted that Wilna was in danger of encirclement from the northwest and the southwest (see Figure 142). An attack by the Fuehrer Escort Battalion was not possible since it was already under attack. An attack toward Wilna would only be possible by units arriving from the west.

Colonel General Reinhardt spoke to Field Marshal Model concerning the Fuehrer's decision. Reinhardt stressed, "that it was insanity to give troops the order to hold when they can not hold at all."521 Lt. General Krebs, Chief of Staff of Army Group Center called Col. General Reinhardt after Reinhardt's conversation with Field Marshal Model and explained the Fuehrer's decision to him. The order to hold Wilna had been transmitted at 0200 hrs by Army Group Center directly to General Stahel in Wilna. The Luftwaffe 
received the mission to support the battle at Wilna. Col. General Reinhardt responded:

that the decision to hold the fortress would create a new hole which the army could not plug because the army has no more forces. It is too bad for the troops in Wilna. The command of the Army is placed in question through this order. 522

Army Group Center awaited a new decision of the Fuehrer which was expected during the afternoon. Col. General Reinhardt noted that this appeared "too late" for the case of Wilna.523 The Soviets during the night forced the garrison of Wilna back to the general line of the south edge of the rail station to directly east of the eastern entrance - cathedral square - south bank of the Wilja river. The main battle line in the western sector northwest of the rail station remained under German control (see Figure 143).

Meanwhile, Panzer Grenadier Brigade von Werthern had since 0545 hrs been attacking Mejszagola (see Figure 143). Soviet resistance was broken and reconnaissance was dispatched from Mejszagola to the south and east (see figure 143).

Kampfgruppe Tolsdorf reported at $0940 \mathrm{hrs}$ that the Soviets had reached the western exit of Wilna and further strong elements were in Ludwinowo and east of it (see Figure 143). Lt. Colonel Tolsdorf reported that he could not attack because there were no available heavy weapons and artillery. Therefore, the following order was issued:

The Kampfgruppe will take the defensive and defend the presently held Waka sector between Landwarow-Gorale 
to the junction with the Wilja river. Reconnaissance is to be conducted to the southeast up to the bend in the river. All arriving elements are upon arrival to be placed under the command of Lt. Colonel Tolsdorf. All bridges are to be blown up as possible so long as explosives are available. ${ }^{524}$

The Soviets during the course of the day closed the ring tighter around "Fortress Wilna." (see Figure 143). The German attack from the west toward Wilna failed due to the shortage of anti-tank weapons.525 Strong Soviet forces advanced south of Wilna to the west and reached the stream sector of Landwarow and occupied Gorale and the rail line to the southeast (see Figure 143). Maj. General Heidkaempfer reported that aerial reconnaissance had observed a Soviet column on the road from Wilna to the southwest containing 28 trucks, 2 tanks and a recon car.

The Soviets attacked "Fortress Wilna" during the evening from the southeast and east with infantry and armor. The Soviets succeeded in breaking through several German positions and infiltrated the inner city (see Figure 143).526 Violent battles continued throughout the city leaving it in flames in several places as a direct result of artillery fire. 12 Soviet tanks had been destroyed. Air supply of Wilna was in operation, but General Stahel notified 3rd Panzer Army Headquarters at 2000 hrs that a spotlight could not be used to identify the place for the supply drops at night since the city was burning. Soviet fighter aircraft covered the entire battle area and the Soviet Flak defense southeast of the city was active. The Soviets had managed to settle into many parts of the city and interfere with German movement by $2320 \mathrm{hrs} .527$ 
German Flak Battalion 296 had proven successful in knocking out Soviet tanks during the fighting which had proved decisive for the entire garrison of the fortress.528 Three Soviet tanks entered the rail strongpoint of Stare Troki west of Wilna. The Soviets northwest of Wilna had reached the north bank of the Wilja river in the woods $4 \mathrm{~km}$ northeast of Nykonty.

The relief effort for Wilna was being assembled in Kauen north of the rail line and elements of the 6th Panzer Division including a panther tank battalion had arrived by evening. ${ }^{529}$ The 69th and 93th Infantry Divisions along with a parachute battalion would be assembled at Kauen shortly. This attack group forming in the area Kauen-Jonawa-Wilkomir was assigned the task of restoring contact with "Fortress Wilna" and the south wing of the IX Army Corps. The mobile forces of the group would be employed to delay the advance of the Soviets in the area around and north of Wilna.

IX Army Corps. The commanding general of IX Corps informed Col. General Reinhardt that the troops holding the line on the outermost left flank had experienced a rupture of their front. The Soviets were advancing on Sela and were already further west and south of Tauragnai lake. Col. General Reinhardt gave the IX Corps Commander freedom to withdraw to the line Orinos lake-Lakajai lake-east of Labanoras-to the eastern tip of Alsetos lake. The IX Corps was to maintain contact with the 391st Security Division on its right and on the left contact with Taurignai lake. Soviet spearheads were reported at $1030 \mathrm{hrs}$ on the highway before Utena. 
Army Group North was sending assault guns to clear the Duenaburg-Utena road. Soviet pressure on the German defense of the rail line on both sides of Svencioneliai increased (see Figure 141). The 225th Infantry Division was now in action and the Soviets had been forced out of Garniai to Juknenai. The division was clearing the road to the southeast and in the direction of Utena. Army Group North reported that the 225th Infantry Division had retaken Tauragnai during the evening. However, a hole between the left wing of the 252nd Infantry Division $7 \mathrm{~km}$ southwest of Tauragnai and Tauragnai lake remained open. Colonel Praefke, Chief of Staff of IX Corps informed Lt. General Krebs, Chief of Staff Army Group Center that the attack to the east from the north bank of Tauragnai lake by the attack group of the II Army Corps of Army Group North would widen the gap between the 16th Army and elements of the 3rd Panzer Army since the Soviets were advancing west on the south side of Taupagnai. Combat engagements near Utena were occurring. The 225th Infantry Division was fighting northeast of Utena. Army Group North continued to be assigned the task of making contact with the 3rd Panzer Army's north wing. 530 This contact was to be made at a small lake near Indibakiai.

\section{4th Army}

Kampfgruppe Weidling on the right wing of the 4th Army was withdrawn to a new position southwest and west of Lida. The 4th Army front by the evening ran from south of Jasiunai $8 \mathrm{~km}$ east of Salcininkavi to Devyanishkes with a mobile defense north and east 
of Voronovo. Key divisions of the 4th Army had been greatly reduced in strength by continuous action. The following divisional strengths of anti-tank guns and tanks were reported for July 9 , 1944:

5th Panzer Division: 6 Panzerkampfwagen IV 12 Panzerkampfwagen $V$

Panthers

6 towed heavy anti-tank

guns

6 self-propelled anti-tank guns

7th Panzer Division: 26 Panzerkampfwagen IV

6 Sturmgeschuetz (assault guns)

20 heavy anti-tank guns

13 heavy $(88 \mathrm{~mm})$ anti-tank guns

170th Infantry Division: 6 towed heavy anti-tank guns

The 170th Infantry Division was no longer capable of defensive operation. 531 The 50th Infantry Division with 6 battalions had taken over the southern defensive sector of the 4th Army. The 4th Army had lost by July 10, 1944130,000 out of an original strength of 165,000 men which meant that $78 \%$ of the old 4th Army had been lost. 532

The remnants of the old 4th Army had been routed and only small isolated groups of desperate German soldiers attempting to reach German lines in the west remained and of these troops only 80 officers and 838 soldiers returned to German lines. ${ }^{533}$ The Commander of the 2nd Belorussian Front assigned the 49th Army to liquidate the remnants of the encircled German forces. The 38th Rifle Corps was given the specific task to comb the terrain east of 
the Ptich river to mop up the isolated small pockets of German troops.

The tragic fate of the German 4th Army was marked by a short message from the Fuehrer which was transmitted to the armies of Army Group Center by Field Marshal Model:

The Fuehrer in conference with me today expressed his satisfaction with the conduct of the troops of the Army Group which have been involved in the heavy battles of the last few days. Reinforcements will be arriving. With them we must successfully accomplish the tasks set us. 534

\section{2nd Army}

Kampfgruppe von Vormann. The troops were exhausted from the previous day's engagements and could not hold the defensive line east of Slonim any longer (see Figure 144). They were withdrawn under constant Soviet pressure to the west bank of the Szczara. The 4th and 12th Panzer Divisions withdrawal progressed as planned (see Figure 144). The 28th Jaeger Division was locked in heavy combat with the Soviets northeast of Slonim (see Figure 144). Elements of the 4th Panzer Division attacked from Slonim to the northeast to provide some relief. 535 The Soviets with weak forces had already forced a crossing over the Szczara $15 \mathrm{~km}$ north of Slonim (see Figure 144). German local reserves were rushed to counter this penetration. 